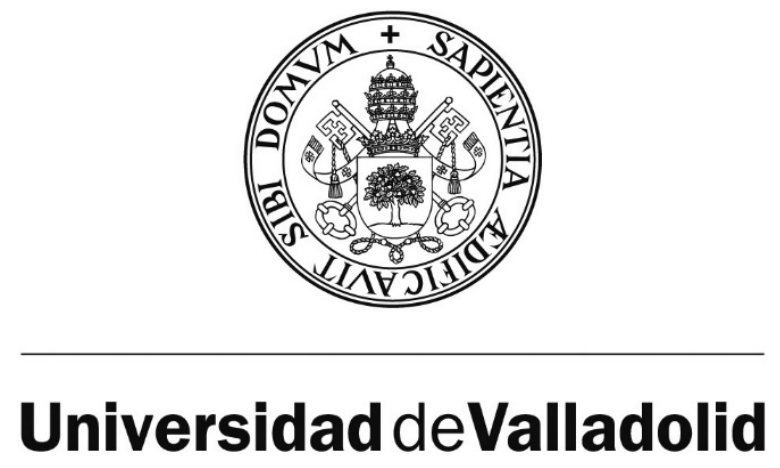

ESCUELA DE INGENIERÍAS INDUSTRIALES

DEPARTAMENTO DE INGENIERÍA QUÍMICA Y TECNOLOGÍA DEL MEDIO AMBIENTE

TESIS DOCTORAL:

\title{
ANAEROBIC TREATMENT OF MUNICIPAL WASTEWATER IN MEMBRANE BIOREACTORS UNDER PSYCHROPHILIC CONDITIONS
}

Presentada por João Artur Ferraz Gouveia para optar al grado de doctor por la Universidad de Valladolid

Dirigida por:

Dra. Ma DEL MAR PEÑA MIRANDA

Dr. FERNANDO FERNANDEZ-POLANCO FERNANDEZ DE MOREDA 



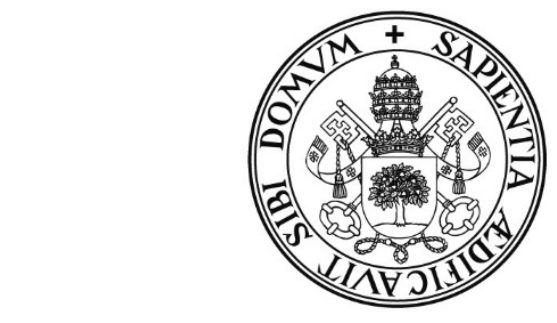

\title{
Universidad deValladolid
}

\author{
ESCUELA DE INGENIERÍAS INDUSTRIALES
}

DEPARTAMENTO DE INGENIERÍA QUÍMICA Y TECNOLOGÍA DEL MEDIO AMBIENTE

TESIS DOCTORAL:

TRATAMIENTO ANAEROBIO DE AGUAS RESIDUALES URBANAS EN REACTORES DE MEMBRANA EN CONDICIONES PSICROFÍLICAS

Presentada por João Artur Ferraz Gouveia para optar al grado de doctor por la Universidad de Valladolid

Dirigida por:

Dr. Ma DEL MAR PEÑA MIRANDA

Dr. FERNANDO FERNANDEZ-POLANCO FERNANDEZ DEMOREDA 



\section{UNIVERSIDAD DE VALLADOLID \\ ESCUELA DE INGENIERÍAS \\ INDUSTRIALES}

\section{Secretaría}

La presente tesis doctoral queda registrada en el folio número del correspondiente libro de registro número

Valladolid, a de 2016

Fdo. El encargado del registro 



\section{Dra. Ma DEL MAR PEÑA MIRANDA}

Profesora Titular

$\&$

\section{Dr. FERNANDO FERNANDEZ-POLANCO FERNANDEZ DEMOREDA}

Catedrático de Universidad

Departamento de Ingeniería Química y Tecnología del Medio Ambiente Universidad de Valladolid

Certifican que:

João Artur Ferraz Gouveia ha realizado bajo su dirección el trabajo "Anaerobic Treatment of municipal Wastewater in Membrane Bioreactors under Psychrophilic Conditions", en el Departamento de Ingeniería Química y Tecnología del Medio Ambiente de la Escuela de Ingenierías Industriales de la Universidad de Valladolid. Considerando que dicho trabajo reúne los requisitos para ser presentado como Tesis Doctoral expresan su conformidad con dicha presentación.

Valladolid, a de 2016

Fdo. $M^{\mathrm{a}}$ DEL MAR PEÑA

MIRANDA
Fdo. FERNANDO

FERNANDEZ-POLANCO

FERNANDEZ DE MOREDA 

Reunido el tribunal que ha juzgado la Tesis Doctoral titulada "Anaerobic Treatment of municipal Wastewater in Membrane Bioreactors under Psychrophilic Conditions” presentada por João Artur Ferraz Gouveia y en cumplimiento con lo establecido por el Real Decreto 99/2011 de 28 de enero de 2011 acuerda conceder por la calificación de

Valladolid, a de 2016 



\section{Agradecimientos}

En primer lugar agradecer a mis directores de tesis $M^{a}$ del Mar Peña Miranda y Fernando Fernandez-Polanco Fernandez de Moreda por darme la oportunidad de conocer el maravilloso mundo de la investigación, por confiar en mi trabajo y por su preocupación tanto personal como profesional.

Gracias al Departamento de Ingeniería Química y Medio Ambiente donde he pasado los últimos ocho años por su acogida, a todas las personas que me han ayudado a sacar esta tesis adelante con su trabajo. Gracias a la empresa CADAGUA por facilitarnos el camino y el trabajo.

No puedo olvidar a mis compañeros, amigos y técnicos del laboratorio con los cuales he compartido despacho e incontables horas de trabajo. A Raúl Muñoz, Roberto Velásquez, Sara Santamarta Morago, Araceli Crespo, Theo, Cati, Guillermo, Isra, Iris, Jaime y a todos los demás, muchas gracias.

Agradecer a mi familia, mis grandes amores (madre, hermana, cuñado, sobrino, Sara y Canita) por todo su cariño y confianza, por saber guiarme en las decisiones difíciles y apoyarme en todo momento, sin vosotros nunca habría llegado tan lejos. Muchas Gracias, os quiero mucho.

A mi padre...te echo de menos...

João Gouveia 



\section{Acknowledgments}

First of al, I would like to thank my thesis supervisors, Maria del Mar Peña Miranda and Fernando Fernandez-Polanco Fernandez de Moreda, for giving me the opportunity to meet the wonderful world of research, for trusting me and for their support at both personal and professional levels.

My thanks to the Department of Chemical Engineering and Environment, where I spent the last eigth years, for their hospitality, to all persons who have helped me with this thesis. My thanks as well to the company CADAGUA for all the support in this work.

I cannot forget my colleagues, friends and lab technicians with whom I shared office and countless hours of work. To Raul Muñoz, Roberto Velásquez, Sara Santamarta Morago, Araceli Crespo, Theo, Cati, Guillermo, Isra, Iris, Jaime and all others, thank you very much.

And thanks to my family, my big loves (mother, sister, brother in law, nephew, Sara and Canita) for all your love and trust, for knowing how to guide me through the difficult decisions and supporting me at any time. Without you I would never have come so far. Thank you, I love you very much.

To my father ... I miss you...

João Gouveia 



\section{Table of Contents}



$\begin{array}{ll}\text { Abstract } & \text { xxii }\end{array}$

Resumen $\quad$ xxvii

$\begin{array}{ll}\text { Thesis outline } & \text { xxxiii }\end{array}$

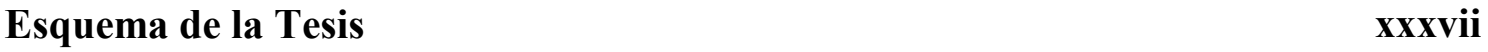

CHAPTER 1. Introduction $\quad 1$

1.1. Treatment of municipal wastewater 3

1.2. Anaerobic Digestion $\quad 6$

1.3. Upflow anaerobic sludge blanket (UASB) reactor $\quad \mathbf{1 1}$

$\begin{array}{lr}\text { 1.4. Membrane Bioreactors (MBR) } & 14\end{array}$

$\begin{array}{lr}\text { 1.5. AnMBR configurations } & \mathbf{1 5}\end{array}$

1.6. Fundamentals of Membrane Processes 19

1.7. Membrane Cleaning $\quad 25$

1.8. Other methods for controlling membrane fouling $\mathbf{2 6}$

$\begin{array}{lr}\text { 1.9. References } & \mathbf{2 7}\end{array}$

$\begin{array}{ll}\text { CHAPTER 2. Objectives } & 35\end{array}$

$\begin{array}{ll}\text { 2.1. Main Objectives } & \mathbf{3 7}\end{array}$

CHAPTER 3. Materials and Methods

3.1. Introduction 4

3.2. Municipal wastewater 4

3.3. General description of the pilot plants 
CHAPTER 4. Long-term operation of a pilot scale anaerobic membrane bioreactor (AnMBR) for the treatment of municipal wastewater under psychrophilic conditions

4.1. Introduction 
5.1. Introduction

5.2. Objectives

CHAPTER 6. A novel configuration for anaerobic submerged membrane bioreactor (AnSMBR) configuration. Long-term treatment of municipal wastewater under psychrophilic conditions

6.1. Introduction 
7.5. Results and Discussion

7.6. Conclusions

7.7. References

CHAPTER 8. General Conclusions

List of figures

List of tables

Nomenclature

243 
Abstract 

Municipal wastewaters are the most common type of wastewater, characterized by a low organic load and a high content of particulate organic matter and are increasingly considered as a source of energy and nutrients. There has been a growing interest in increased profitability and sustainability of systems for municipal wastewater treatment.

The activated sludge process is the most widely used to treat this wastewater. However, this treatment presents some clear disadvantages when compared to anaerobic treatment, such as high energy consumption, high yield of sludge growth and high cost of sludge manipulation. In contrast, anaerobic processes, which are widely used for industrial wastewater treatment, and could be an attractive treatment for municipal wastewater, have many advantages over the aerobic treatment.

Anaerobic processes strongly depend on operational temperature and therefore the heating of the large volume of municipal wastewater makes mesophilic anaerobic treatment economically unviable in cold or temperate countries.

The low strength of municipal wastewater, together with the slow growth rate of methanogens at temperatures below $20^{\circ} \mathrm{C}$ and the limiting step, the hydrolysis of particulate matter, are the major disadvantages of the anaerobic treatment at psychrophilic conditions. Therefore, the combination of anaerobic process plus membrane filtration could be an appropriate technology, avoiding the loss of slow-growing bacteria.

The general objective of this thesis is to assess the long term feasibility of the treatment of municipal wastewater in a pilot scale AnMBR, consisting of an UASB reactor coupled with an ultrafiltration membrane unit, and the general performance of a pilot scale AnSMBR with a novel membrane configuration, UASB reactor and filtration section in a single unit, both under psychrophilic conditions $\left(18 \pm 2^{\circ} \mathrm{C}\right)$. Operability of the membrane, the influence of the HRT, the volumetric loading rate (VLR), the effect of the membrane on the treatment of municipal wastewater at psychrophilic conditions, the recirculation rate between UASB and the membrane module on the effluent quality were studied and operational strategies of two pilot plants were compared in order to determine the influence on long-term operation on the viability of the membrane technology treating municipal wastewater under psychrophilic conditions $\left(18 \pm 2^{\circ} \mathrm{C}\right)$. 
In order to achieve the aims of this thesis, two pilot plants are designed, constructed and operated. Both pilot plants were continuously fed with raw municipal wastewater from the city of Valladolid drawn from a nearby sewer.

The AnMBR and AnSMBR were inoculated with flocculent sludge and granular sludge from a mesophilic reactor, respectively, without previous acclimatization to psychrophilic conditions.

In the first configuration (AnMBR), the reactor obtained removal efficiencies of tCOD of $87 \pm 1 \%$ and HRT of $7 \mathrm{~h}$, volumetric loading rate between 2 and $2.5 \mathrm{~kg} \mathrm{tCOD} / \mathrm{m}^{3} \mathrm{~d}$. tCOD effluent concentrations reached $100-120 \mathrm{mg} \mathrm{O}_{2} / \mathrm{L}$ and $\mathrm{BOD}_{5}$ concentrations of 30-35 mg O $\mathrm{O}_{2} / \mathrm{L}$. Specific methane production between 0.18 and $0.23 \mathrm{Nm}^{3} \mathrm{CH}_{4} / \mathrm{Kg}$ $\mathrm{COD}_{\text {removed }}$ were achieved, depending on the recirculation between the membrane module and the UASB reactor. The permeate flux varied from 10 to $14 \mathrm{~L} / \mathrm{m}^{2} \mathrm{~h}$, using a cycle of backwash, filtration and pause, with continuous biogas sparging between 40-60 $\mathrm{m} / \mathrm{h}$ with a value transmembrane pressure of $400-550$ mbar. The granulation of sludge was observed eight months after reinoculation.

The permeability of the new membrane for the AnMBR was between $0.96-1.05 \mathrm{~L} \mathrm{~m}^{-2}$ $\mathrm{h}^{-1}$ mbar $^{-1}$. The resistance limit of the new membrane was never reached with different cleanings, and the achieved cleaning efficiency was between $65-88.5 \%$.

The specific cake resistance of the particulate matter accumulated in the membrane module remained between 0.15 and $0.5^{*} 10^{13} \mathrm{~m}^{-1}$ throughout the operation period.

In the new configuration (AnSMBR), degranulation of the sludge has not been observed. Removal efficiencies of $90 \%$ were obtained, when working with a volumetric loading rate between 1.6 and $2.0 \mathrm{Kg} \mathrm{COD} / \mathrm{m}^{3} \mathrm{UASB}$ d, HRT of 12.8 to $14.2 \mathrm{~h}$. The specific methane production was $0.22 \mathrm{Nm}^{3} \mathrm{CH}_{4} / \mathrm{g}$ tCOD removed operating without or with recirculation. Dissolved methane oversaturation in the effluent was observed, reaching average values of $19.1 \pm 0.84 \mathrm{mg} \mathrm{CH} / \mathrm{L}$. The membrane was operated with a cycle of backwash, filtration and pause, with continuous biogas sparging $(9-16 \mathrm{~m} / \mathrm{h})$. Periodic purges of particulate matter accumulated in the filtration section were carried every 160 days. In this conditions, the permeate flow rate ranged from 10 to $14 \mathrm{~L} / \mathrm{m}^{2} \mathrm{~h}$ with 
transmembrane pressure (TMP) values of 400-550 mbar. During the three years of continuous operation, the membrane was not physically or chemically cleaned.

The permeabilities of the membranes 1 and 2 were 1.0234 and $1.258 \mathrm{~L} \mathrm{~m}^{-2} \mathrm{~h}^{-1} \mathrm{mbar}^{-1}$, respectively, and, with the cleaning procedures, a cleaning efficiency for the membrane 1 of $98.5 \%$ and to membrane 2 of $97.6 \%$ were reached. 



\section{Resumen}



Las aguas residuales municipales son las más abundantes, se caracterizan por una baja carga orgánica y un alto contenido de materia orgánica particulada y se consideran cada vez más como una fuente de energía y nutrientes. Lo que hace que haya un creciente interés por la mejora energética y la sostenibilidad de los sistemas de tratamiento.

El proceso de fangos activados es el más ampliamente utilizado para el tratamiento de estas aguas residuales. Sin embargo, este tratamiento presenta algunas claras desventajas cuando se compara con el tratamiento anaeróbico, como son el alto consumo energía, alta producción de fango y el alto coste en la manipulación de lodos. Por el contrario, los procesos anaerobios, que son ampliamente utilizados para el tratamiento de aguas residuales industriales, podrían ser un tratamiento atractivo para las aguas residuales municipales, considerando las ventajas que presentan respecto al tratamiento aeróbico.

Los procesos procesos de tratamiento anaerobio dependen de la temperatura de operación, sin embargo el calentamiento de grandes cantidades de aguas residuales municipales hace que el tratamiento anaerobio mesófilo no sea económicamente viable en países fríos o templados. La baja carga de las aguas residuales municipales, junto con la baja tasa de crecimiento de las bacterias metanógenicas a temperaturas inferiores al rango mesofílico y la etapa limitante de la hidrólisis de la materia orgánica partículada, son las principales desventajas del tratamiento anaeróbico en condiciones psicrófilas. En este sentido, la combinación de un proceso de tratamiento anaerobio más una membrana de filtración, podría ser una tecnología apropiada para el tratamiento del agua residual urbana a baja temperatura, evitando la pérdida de bacterias de crecimiento lento y aumentando el tiempo de retención de los sólidos.

El objetivo general de esta tesis es evaluar la viabilidad a largo plazo del tratamiento anaerobio de aguas residuales urbanas en reactores de membrana en condiciones psicrofílicas. Para ello se han operado dos plantas piloto formadas por un reactor anaerobio tipo UASB seguido de una membrana de ultrafiltración. En una de las plantas piloto (AnMBR) la configuración de la membrana ha sido sumergida externa, y en la otra planta la configuración de la membrana ha sido sumergida interna (AnSMBR). Ambas plantas han operado en condiciones psicrófilas $\left(18 \pm 2^{\circ} \mathrm{C}\right)$ y han sido alimentadas con agua residual urbana procedente del colector muncipal previamente tratado en un 
rototamiz y sedimentador. En cada caso se ha estudiado la influencia que las variables fundamentales del proceso biológico anaerobio, como el tiempo de residencia, la carga volumétrica y carga másica, tienen en el rendimiento de eliminación de materia orgánica. Así como las condiciones de operación de la membrana en ambas configuraciónes y la velocidad de recirculación entre el reactor y el módulo de filtración. Comparar las estrategias de operación de las dos plantas piloto con el fín de determinar la influencia a largo plazo sobre la viabilidad de la tecnología de membranas en el tratamiento de aguas residuales municipales en condiciones psicrofílicas $\left(18 \pm 2^{\circ} \mathrm{C}\right)$.

La planta piloto AnMBR ha sido inoculada con fango floculento sin aclimatar a condiciones psicrofílicas procedente del digestor mesófilo de la EDAR de Valladolid. Mientras que la planta AnSMBR fue inoculada con fango granular también sin aclimatar acondiciones psicrofílicas, procedente de un reactor mesófilo de fábrica de papel reciclado.

En la configuración (AnMBR) se observó la granulación del fango aproximadamente a los ocho meses de la reinoculación. Se obtuvieron rendimientos de eliminación de DQOt del $87 \pm 1 \%$ con un TRH de $7 \mathrm{~h}$, y una carga volumétrica entre 2 y $2.5 \mathrm{~kg}$ DQOt $/ \mathrm{m}^{3} \mathrm{~d}$. La concentración de tDQO del efluente alcanzó $100-120 \mathrm{mg} \mathrm{O} / \mathrm{L}$ y las concentraciones de $\mathrm{DBO}_{5}$ de $30-35 \mathrm{mg} \mathrm{O} / \mathrm{L}$. La producción específica de metano

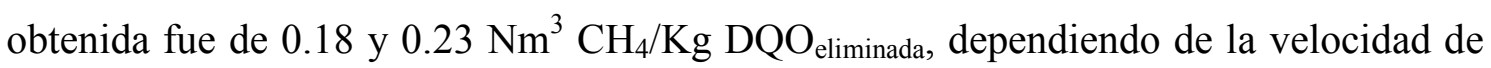
recirculación entre el módulo de membrana y el reactor UASB. La membrana ha operado utilizando un ciclo de filtración/contralavado/relajación y burbujeo continuo de biogás con velocidades ascensionales entre 40-60 m/h. En estas condiciones se ha operado mayoritariamente con un flujo de permeado entre $10-14 \mathrm{~L} / \mathrm{m}^{2} \mathrm{~h}$, alcanzándose una presión transmembrana de 400-550 mbar, siendo necesario lavar químicamente la membrana aproxidamente cada medio año de operación.

La permeabilidad de la membrana nueva de la planta AnMBR está comprendida entre 0.96-1.05 $\mathrm{L} \mathrm{m}^{-2} \mathrm{~h}^{-1} \operatorname{mbar}^{-1} \mathrm{y}$ después de las diferentes limpiezas químicas no se recupera completamente esta permeabilidad, se alcanzan eficacias de limpieza entre el $65-88.5 \%$.

La resistencia específica del material particulado acumulado en el módulo de membrana se ha mantenido entre 0.15 y $0.5^{*} 10^{13} \mathrm{~m}^{-1}$ a lo largo del periodo de operación. 
En la configuración (AnSMBR), no se ha observado desgranulación del fango. Se obtuvieron rendimientos de eliminación de DQO del 90\% operando con una carga volumétrica entre 1.6 y $2.0 \mathrm{Kg}$ DQOt $/ \mathrm{m}^{3}$ UASB d, y un TRH de 12.8 a $14.2 \mathrm{~h}$. La producción específica de metano fue de $0.22 \quad \mathrm{Nm}^{3} \quad \mathrm{CH}_{4} / \mathrm{g}_{\text {DQOt }}$ eliminada, independientemente de la velocidad de recirculación entre la sección de filtración y el reactor UASB. Se observó la sobresaturación de metano disuelto en el efluente, alcanzando un valor medio de $19.1 \pm 0.84 \mathrm{mg} \mathrm{CH} / \mathrm{L}$. La membrana ha operado con un ciclo de filtración/contralavado/relajación y burbujeo continuo de biogás con velocidades ascensionales entre 9-16 m/h. Se han realizado purgas periódicas del material particulado acumulado en la sección de filtración cada 160 días. En estas condiciones se ha operado con un flujo de permeado entre entre $10-14 \mathrm{~L} / \mathrm{m}^{2} \mathrm{~h}$ con una presión transmembrana de 400-550 mbar. La membrana no se ha lavado ni física ni químicamente durante tres años de operación.

Las permabilidades de las membranas nuevas 1 y 2 de la planta AnSMBR son $1.0234 \mathrm{y}$ $1.258 \mathrm{~L} \mathrm{~m}^{-2} \mathrm{~h}^{-1} \mathrm{mbar}^{-1}$, respectivamente, alcanzando con los procedimientos de limpieza química realizados una efíciencia de limpieza de la membrana 1 del $98.5 \%$ y para la membrana 2 del 97.6\%. 

Thesis Outline 

This doctoral thesis focuses on the treatment of municipal wastewater using AnMBR and AnSMBR in psychrophilic conditions, and is presented in the following way:

In Chapter 1 the general introduction of the thesis is presented. A brief description of anaerobic treatment of municipal wastewater, anaerobic digestion, the use of UASB reactor in treatment of wastewater, the membrane bioreactors, the possible configurations of anaerobic membrane reactors, the fundamentals of membrane processes and the membrane cleaning is covered in this chapter.

Chapter 2 presents the main goals of the thesis.

Chapter 3 presents the material and methods, where it is described a detailed explanation of the two pilot plants used during the study and analytical procedures.

Chapter 4 describes the operation and performance of an AnMBR for more than 3 years. It is designed, constructed and operated an UASB reactor coupled to an external submerged membrane module (AnMBR) to treat municipal wastewater to $18 \pm 2{ }^{\circ} \mathrm{C}$. Experimentally is evaluated the operational capacity of the membrane, the influence of HRT, the volumetric loading rate, the effect of the membrane in the treatment of municipal wastewater, the recirculation between UASB and the membrane module, and the effluent quality.

In Chapter 5, the specific cake resistance from different sampling points in the AnMBR during the period of operation was determined. Furthermore, the behavior of sludge with the addition of a cationic polymer (PermaCare MPE50 ${ }^{\mathrm{TM}}$ ), at lab-scale and in the pilot plant, was assessed.

In Chapter 6 the results obtained with a new configuration of the anaerobic reactor (AnSMBR) to treat municipal wastewater at $18 \pm 2{ }^{\circ} \mathrm{C}$ are displayed. The new configuration of the pilot plant it is designed constructed and operated during 3 years. This new configuration consists of UASB reactor with a membrane immersed ultrafiltration on top the reactor UASB.

Besides evaluating experimentally the operational capacity of the membrane, the influence of HRT, the volumetric loading rate, the effect of the membrane in the 
treatment of municipal wastewater, the recirculation between the membrane module and the UASB, and the effluent quality, the assessment of the oversaturation and losses of methane in the effluent were also proposed.

Chapter 7 presentes the cleaning procedures of the membranes (physical, oxidant and acid). For all cleaning procedures, one begins with the characterization of the membrane before and after each cleaning (physical, oxidant or acid), proceeding after to the evaluation of the membrane resistance and permeability. For both pilot plants, the physical cleaning was carried out with water jets. The oxidant and acid cleaning for AnMBR was done with $1000 \mathrm{ppm}$ of $\mathrm{NaClO}$ and $1 \mathrm{~g} / \mathrm{L}$ of HCL, respectively. For the AnSMBR, the oxidant cleaning was carried out with $1000 \mathrm{ppm} \mathrm{NaClO}$, and acid cleaning with citric acid $(1 \mathrm{~g} / \mathrm{L}$ and $2 \mathrm{~g} / \mathrm{L}), \mathrm{HCl}(1 \mathrm{~g} / \mathrm{L})$ and EDTA $(1 \mathrm{w} \%)$, respectively. 


\section{Esquema de la Tesis}



Esta tesis doctoral se centra en el tratamiento de las aguas residuales municipales utilizando dos plantas piloto AnMBR y AnSMBR en condiciones psicrofílicas, y se presenta de la siguiente forma:

El Capítulo 1 se presenta la introducción general de la tesis. Se muestra una breve descripción del tratamiento anaeróbico de aguas residuales municipales, de la digestión anaeróbica, del uso del reactor UASB en el tratamiento de aguas residuales, de los reactores de membrana, las posibles configuraciones de reactores anaerobios de membrana, los fundamentos de los procesos de membrana y la limpieza de la membrana.

El Capítulo 2 presenta los objetivos principales de la tesis.

En el Capítulo 3 se presentan los materiales y métodos, donde se describe con una explicación detallada las dos plantas piloto utilizadas durante el estudio y los procedimientos analíticos.

El Capítulo 4 describe la operación de la planta piloto AnMBR durante más de 3 años. Se ha diseñado, construido y operado un reactor UASB acoplado a un módulo de membrana sumergida externa (AnMBR) para el tratamiento de aguas residuales municipales a $18 \pm 2^{\circ} \mathrm{C}$. Experimentalmente se evalúa la capacidad operativa de la membrana, la influencia del TRH, la carga volumétrica, el efecto de la membrana en el tratamiento de aguas residuales municipales, la recirculación entre UASB y el módulo de membrana, y la calidad del efluente.

En el Capítulo 5 se determina la resistencia específica de la torta, de diferentes zonas de la planta piloto AnMBR durante el período de funcionamiento. Además se añade y observa el comportamiento del lodo con la adición de un polímero catiónico $\left(\right.$ PermaCare MPE50 ${ }^{\mathrm{TM}}$ ), a escala de laboratorio y en la planta piloto, respectivamente.

En el Capítulo 6 se muestran los resultados obtenidos en la planta piloto con la configuración de membrana sumergida interna (AnSMBR) para el tratamiento de aguas residuales municipales a $18 \pm 2^{\circ} \mathrm{C}$. Esta planta piloto ha sido diseñada construida $\mathrm{y}$ 
operada durante 3 años. Esta nueva configuración consiste en reactor UASB con una membrana de ultrafiltración sumergida, en la parte superior del reactor UASB.

Se ha evaluado experimentalmente la capacidad operativa de la membrana, la influencia del TRH, la carga volumétrica, el efecto de la membrana en el tratamiento de aguas residuales municipales, la recirculación entre el módulo de membrana y UASB en la calidad del permeado. Se ha determina también el metano disuelto en el efluente.

El Capítulo 7, se presenta los procedimientos de limpieza (físicos, oxidantes y ácidos) utilizados para la limpieza de las membrnaas. En todos los casos, se comienza con la caracterización de la membrana antes y después de cada limpieza (física, oxidante o ácida), procediendo después a la evaluación de la resistencia y permeabilidad de la membrana. Para ambas plantas piloto, la limpieza física se realiza con agua a presión. La limpieza oxidante y ácida para el AnMBR se hace con 1000 ppm de $\mathrm{NaClO}$ y $1 \mathrm{~g} / \mathrm{L}$ de HCL, respectivamente. Para el AnSMBR, la limpieza oxidante se lleva a cabo con 1000 ppm de $\mathrm{NaClO}$, y la limpieza ácida con ácido cítrico (1 g/L y 2 g/L), HCl (1 g/L) y EDTA $(1 \% \mathrm{w})$, respectivamente. 
CHAPTER 1

Introduction 



\subsection{Treatment of municipal wastewater}

Over the last century, continued population growth and industrialization have resulted in the degradation of various ecosystems on which human life relies on. In the case of ocean and river quality, such pollution is primarily caused by the discharge of inadequately treated industrial and municipal wastewater. On initial discharge, these wastewaters can contain high levels of inorganic pollutants which can be easily biodegradable, but whose impact load on the ecosystems, either in Total Suspended Solids (TSS), Bio-chemical Oxygen Demand $\left(\mathrm{BOD}_{5}\right)$, or Chemical Oxygen Demand (COD), may be in the tens of thousands $\mathrm{mg} / \mathrm{L}$.

Municipal wastewater is the most abundant type of wastewater that falls into the category of low-strength waste streams, characterized by low organic strength and high particulate organic matter content (van Lier, 2008).

In urban wastewater, the major components of the organic fraction are carbohydrates (25-50\%) and proteins (40-60\%) (Bitton, 2010), being phosphatases, glucosidases and proteases amongst the most relevant hydrolases (Molina-Muñoz et al., 2010).

With appropriate analysis and environmental control, almost all wastewaters containing biodegradable constituents with a $\mathrm{BOD} / \mathrm{COD}$ ratio of 0.5 or greater can be treated easily by biological means (Metcalf \& Eddy, 2003).

Municipal wastewater has been regarded more as a resource rather than a waste, especially for current world that faces severe risks such as climate changes, energy crisis and water scarcity (Gao et al., 2014).

In addition, due to an increase in the scarcity of clean water there is need for appropriate management of available water resources (Aiyuk et al., 2006). Some of the goals of environmental protection and resource conservation concepts are the reuse of treated wastewater, residues emanating therefrom, and other treatment by-products (Lettinga et al., 2001). Consequently, by implementing these concepts, a wastewater like domestic sewage, apart from being sanitized, can become an important source of re-usable water, fertilizer, soil conditioner and energy (Aiyuk et al., 2006).

Water reuse is an important measure to simultaneously address fresh water scarcity and environmental pollution. Safe and reliable water reuse requires adequate removal of salts, nutrients (such as nitrogen and phosphorous), pathogenic agents, and trace organic chemicals (TrOCs) from reclaimed effluent (Shannon et al., 2008; Grant et al., 2012). 
Municipal wastewater treatment plants have the potential to become net producers of renewable energy, converting the chemically bound energy content in the organic pollutants of raw municipal wastewater to useful energy carrier in the form of methanerich biogas produced during anaerobic digestion of primary sludge and biomass generated during conventional aerobic treatment. However, approximately $45 \%$ of the total biodegradable chemical oxygen demand is lost through oxidation to carbon dioxide (Smith et al., 2013).

To combat this increasing burden on our aquatic environment, increasingly strict regulation on pollution discharge is being implemented by various governmental bodies, with focus primarily on waste reduction. The treatment systems developed by industry are frequently regarded as a regulatory obligation, increasing capital and running costs and yielding negative economic returns. Compliance to environmental legislations should not necessary lead to the creation of additional costs, but can instead provide a secondary source of income. One possible source of increased revenue available to industries is through taking advantage of the incentives awarded by the Clean Development Mechanism (CDM) under the Kyoto Protocol 1997 (Chan et al., 2009).

The activated sludge process is the most widely used to treat this type of wastewater (Rittmann and McCarty, 2001; Metcalf and Eddy, 2003). However, this treatment presents some clear disadvantages when compared to anaerobic treatment, such as its high cost of aeration and the generation of large amounts of residual sludge. Thus, the main conceptual limitation of the activated sludge process is the high biomass yield that implies the use of energy $\left(\mathrm{O}_{2}\right)$ to transform biodegradable dissolved or suspended organic matter into settleable microorganisms that are often partially converted into biogas using anaerobic digestion.

Anaerobic processes, which are widely used for industrial wastewater treatment, have clear advantages such as a significantly lower generation of excess sludge and the conversion of organic matter into valuable biogas without energy consumption (Baek and Pagilla, 2006; Lin et al., 2013; Smith et al., 2012; van Lier et al., 2001). Therefore, the anaerobic process could be an attractive treatment for municipal wastewater in order to reduce sludge production and to optimize energy use, meanwhile the anaerobic processes strongly depend on operational temperature and therefore the heating of the large volume of municipal wastewater makes mesophilic anaerobic treatment economically unviable in cold or temperate countries. 
The low strength of municipal wastewater, together with the slow growth rate of methanogens at temperatures of below $20^{\circ} \mathrm{C}$, would entail high reactor volume as a result of the high residence times to avoid cell washout (Baek and Pagilla, 2006; Lin et al., 2013; Smith et al., 2012; van Lier et al., 2001), and the hydrolysis of particulate matter into dissolved molecules becomes the rate-limiting step, which results in the accumulation of suspended solids (SS) in the reactor, and a decrease in both organic matter conversion efficiency and methanogenic activity (Lettinga et al., 2001; Martinez-Sosa et al., 2011).

When operating at temperatures in the psychrophilic range, the conventional technologies such as UASB and the expanded granular sludge blanket (EGSB) are not sufficient to maintain the high concentration of active biomass, which is the compulsory condition required for the treatment of low strength wastewaters.

Anaerobic membrane bioreactor (AnMBR) has been gaining attention as a means to treat low strength wastewater using different membrane module configurations including internal or submerged type (Chu et al., 2005; Hu and Stuckey, 2006; Huang et al., 2008), and external or cross flow type (Baek and Pagilla, 2006; Ho et al., 2007), allowing absolute retention of biomass, irrespective of their settling characteristics, a good effluent quality in terms of COD, SS and pathogen count. Furthermore, there is a possibility of reusing and recycling the treated effluent for non-drinkable purposes and for agricultural irrigation, due to macronutrients such as ammonia and orthophosphate, which are not removed by anaerobic processes and pathogens can be retained by the membrane unit (Ozgun et al., 2013).

It is also important to consider dissolved methane in the anaerobic treatment of municipal wastewaters. The loss of dissolved methane is enhanced at lower temperatures because of the higher solubility of the $\mathrm{CH}_{4}$ at lower temperatures, which is the case with the anaerobic treatment of municipal wastewaters in psychrophilic conditions. Normally, in the effluent of anaerobic treatment, the methane is not usually recovered, which results in greenhouse gas emission from the anaerobic treatment process and loss of a potential energy resource. Therefore, in these processes, how much more dissolved methane is recovered, the emission of greenhouse gases is avoided and more biogas is recovered (Bandara et al., 2012).

The selection of an appropriate energy recovery technology that can convert the inherent energy in wastewater into a renewable energy source has become more important (Ozgun et al., 2013). Nowadays a sustainable operation of wastewater 
treatment plants (WWTP) is a general goal. Currently, the power required for the treatment of urban wastewater in Spain is approximately $300 \mathrm{MW}$, equivalent to an average of 5.6 W/PE or a consumption of $50 \mathrm{~kW} \mathrm{h/(PE} \mathrm{year)} \mathrm{(Fernández} \mathrm{et} \mathrm{al.,} \mathrm{2011).}$ Thus, operation of WWTP should be focussed on making sewage treatment selfsufficient, reducing energy requirements and global greenhouse-gas emissions (Giménez et al., 2012).

\subsection{Anaerobic Digestion}

Anaerobic digestion is one of the most important processes used for various industrial wastewaters as well as sewage treatments because it combines pollution reduction and energy production (Lin et al., 2013). Advantages and disadvantages of anaerobic sewage treatment, with special emphasis on high-rate reactors, are in Table 1.1. Anaerobic processes have the advantage of reducing the organic matter of municipal and industrial wastewaters producing energy at the same time; their application to municipal wastewaters, however, appears to be more limited because $\mathrm{CH}_{4}$ production cannot cover heating requirements (An et al., 2009) being, for this reason, easily applied to countries with warmer climates (Kim et al., 2011; Liao et al., 2006). As illustrated in Figure 1.1 the anaerobic degradation of complex organic matter to methane and carbon dioxide, which involves the interaction of four different metabolic groups of bacteria, namely hydrolytic, acidogenic, acetogenic and methanogenic bacteria (Kataoka et al., 1992): 


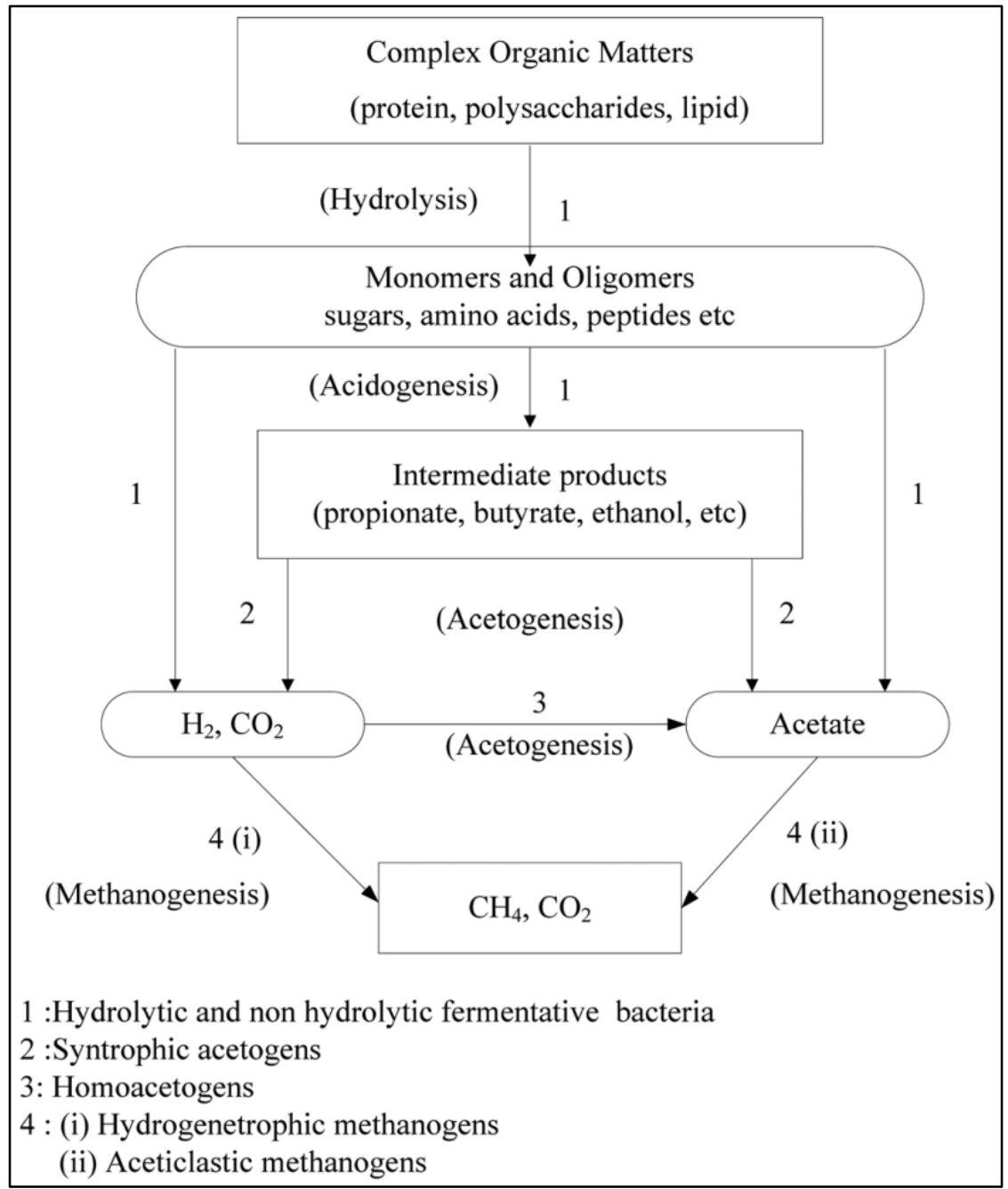

Figure 1.1. Metabolic pathways of anaerobic degradation (Khanal, 2008).

\section{Hydrolisis}

This process consist of bacterial hydrolysis of the complex organic materials (figure 1.1) in order to break down complex insoluble organic polymers and convert them into dissolved compounds with a lower molecular weight; in other words, to make them available for other bacteria. Proteins are converted via (poly) peptides to amino acids, carbohydrates are transformed into soluble sugars (mono-and disaccharides) and lipids are converted into long chain fatty acids and glycerine. In practice, the hydrolysis rate can be limiting for the overall rate of anaerobic digestion, especially taking into account the conversion of lipids in lower temperatures. 


\section{Acidogenesis}

Facultative microorganisms (those that live either in the presence or absence of oxygen) and obligate anaerobic bacteria then convert dissolved compounds into simple organic compounds (volatile fatty acids, alcohols, lactic acid) and mineral compounds such as carbon dioxide, hydrogen, ammonia, and hydrogen sulphide gas. Diversity of acidogenic bacteria is important, especially taking into account accidental presence of oxygen, which otherwise might become toxic to obligate anaerobs such as methanogenic bacteria.

\section{Acetogenesis}

Acetogenic bacteria convert these resulting products of acidogenesis into the final products for methane production: acetate, hydrogen, and carbon dioxide. As can be seen in figure 1.1 a fraction of approximately $70 \%$ of initial COD is converted into acetic acid and the reminder of electron donor capacity is concentrated in the form of hydrogen.

\section{Methanogenesis}

Methanogenesis is often the rate limiting step of the overall anaerobic digestion process, although at lower temperatures it might be hydrolysis. The biochemistry of biogas production dictates that $\mathrm{CO}_{2}$ and $\mathrm{CH}_{4}$ must be produced simultaneously to achieve stable operation. The product $\mathrm{CO}_{2} / \mathrm{CH}_{4}$ ratio is governed by the type of substrates used. There are two main (also some others that are currently regarded as exceptions and less important) of biochemical pathways, that result in biogas: (1) acetoclastic pathway, where methane is produced from acetate, and (2) hydrogenotrophic pathway, where methane is produced from the reduction of carbon dioxide by hydrogen. The stoichiometrical representation of these processes is as follows:

acetotrophic methanogenesis:

$\mathrm{CH}_{3} \mathrm{COOH} \rightarrow \mathrm{CH}_{4}+\mathrm{CO}_{2}$

hydrogenotrophic methanogenesis:

$4 \mathrm{H}_{2}+\mathrm{CO}_{2} \rightarrow \mathrm{CH}_{4}+4 \mathrm{H}_{2} \mathrm{O}$ 
Moreover, hydrogenotrophic bacteria grow faster than those utilizing acetic acid, therefore acetotrophic methanogens (acetoclastic) are usually rate limiting with respect to the conversion of complex macromolecules in wastewater into biogas. Methane forms the main part of the biogas obtained (60-70\%), together with carbon dioxide (30$40 \%$ ), nitrogen gas and negligible content of hydrogen sulphide gas. The composition and enrichment of biogas depends on the degraded material and the process of anaerobic digestion (Buntner, 2013). The methane rich biogas can be used for digester heating, electricity generation or even recycled for fuel production and produce net energy for the WWTP (Lin et al., 2013). 
Table 1.1. Advantages and disadvantages of anaerobic wastewater treatment.

Advantages $\quad$ High efficiency. Good removal efficiency can be achieved in the system, even at high loading rates and low temperatures.

Simplicity. The construction and operation of these reactors is relatively simple.

Flexibility. Anaerobic treatment can easily be applied on either a very large or a very small scale.

Low space requirements. When high loading rates are accommodated, the area needed for the reactor is small.

Low energy consumption. As far as no heating of the influent is needed to reach the working temperature and all plant operations can be done by gravity, the energy consumption of the reactor is almost negligible. Moreover, energy is produced during the process in the form of methane.

Low sludge production. The sludge production is low, when compared to aerobic methods, due to the slow growth rates of anaerobic bacteria. The sludge is well stabilized for final disposal and has good dewatering characteristics. It can be preserved for long periods of time without a significant reduction of activity, allowing its use as inoculum for the start-up of new reactors.

Low nutrients and chemicals requirement. Especially in the case of sewage, an adequate and stable $\mathrm{pH}$ can be maintained without the addition of chemicals. Macronutrients (nitrogen and phosphorus) and micronutrients are also available in sewage, while toxic compounds are absent.

Disadvantages Low pathogen and nutrient removal. Pathogens are only partially removed, except helminth eggs, which are effectively captured in the sludge bed. Nutrients removal is not complete and therefore a posttreatment is required.

Long start-up. Due to the low growth rate of methanogenic organisms, the start-up takes longer as compared to aerobic processes, when no good inoculum is available.

Possible bad odours. Hydrogen sulphide is produced during the anaerobic process, especially when there are high concentrations of sulphate in the influent. A proper handling of the biogas is required to avoid bad smell.

Necessity of post-treatment. Post-treatment of the anaerobic effluent is generally required to reach the discharge standards for organic matter, nutrients and pathogens. 


\subsection{Upflow anaerobic sludge blanket (UASB) reactor}

\subsubsection{Anaerobic Digestion in wastewater treatment}

The first application of anaerobic digestion for wastewater treatment can be dated at the end of the XIX century. M. Mouras (France) developed the system where settleable solids from sewage were "liquefied". Later on, a variety of anaerobic treatment systems was proposed, such as the septic tank or Imhoff tank (figure 1.2). In both systems the wastewater flows through the upper part while the anaerobic sludge remains at the bottom of the tank, allowing the biodegradation of settleable solids. Within the years some modifications were done, such as combining the Imhoff tank with a heated digester. However, the overall efficiency of early anaerobic systems was around 30$50 \%$, due to the low content (one-third to one-half) of settleable fraction in the influent wastewater. On the other hand, to achieve higher removal rate of organic matter, longer contact between the substrate and the anaerobic biomass should be provided.

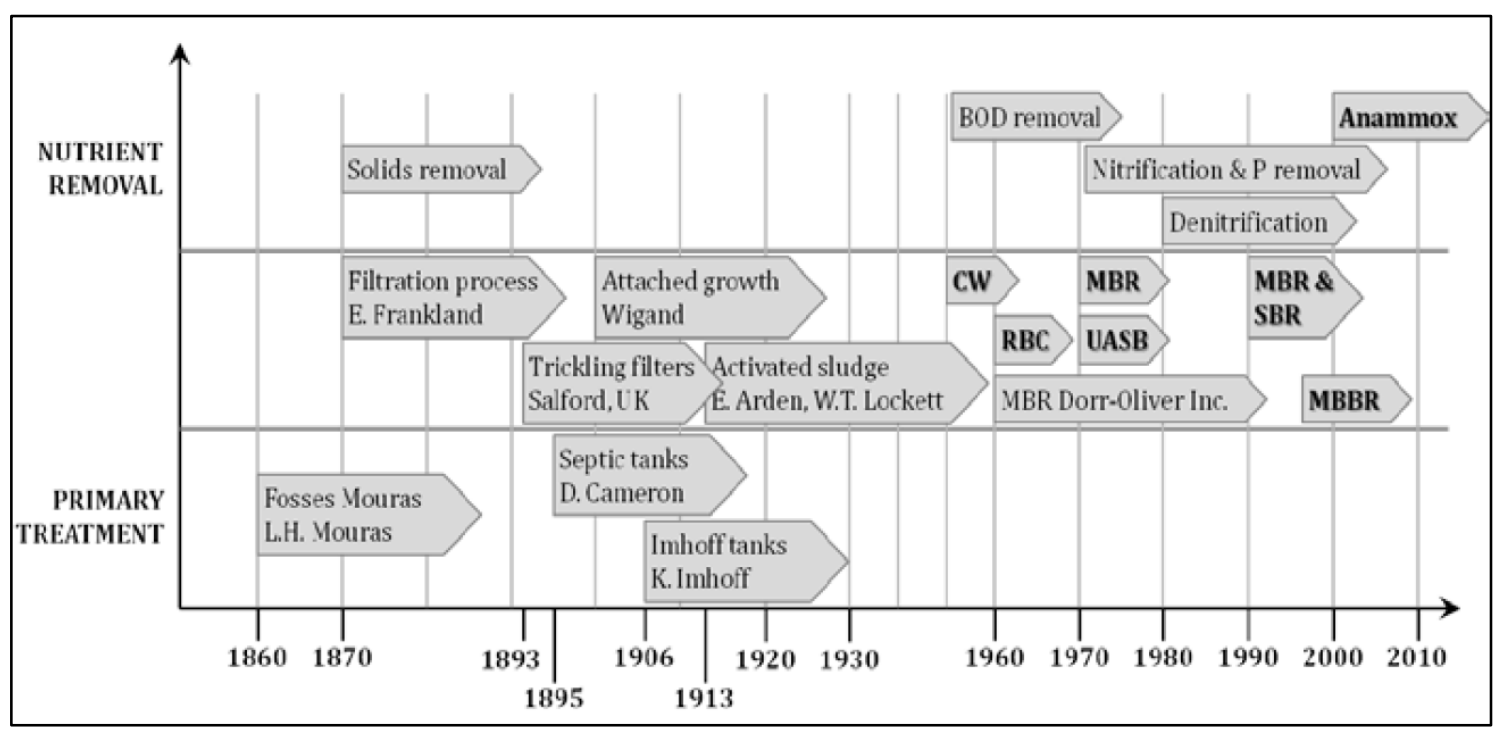

Figure 1.2. Evolution of wastewater treatment. CW- constructed wetlands; RBCrotating biological contactor; UASB- Up-flow Anaerobic Sludge Blanket; MBRMembrane Bioreactor; SBR-Sequencing Batch Reactor; MBBR-Moving Bed Biofilm Reactor (Buntner, 2013). 
This problem was solved by the development of so-called high-rate systems, where the biomass is retained either by immobilization of biomass or simply by applying solidliquid separation, with the return of the separated solids to the reactor. Different anaerobic high-rate reactors could be used for treating either industrial or municipal sewage, e.g.: Anaerobic Filter (AF), UASB, Expanded Granular Sludge Blanket (EGSB) and Fluidized Bed (FB) reactor. From all these systems the UASB and its modifications are the most popular anaerobic reactors for treating both municipal and industrial wastewaters - at present close to $80 \%$ of all full-scale anaerobic installations are sludge bed reactors.

The UASB reactor (figure 1.3) was developed in the 1970s by Prof. Lettinga and his group at University of Wageningen (The Netherlands). The success of UASB reactor relies on the establishment of a dense sludge bed in the bottom of the reactor formed by accumulation of incoming suspended solids and bacterial growth (usually forming flocs and granules).

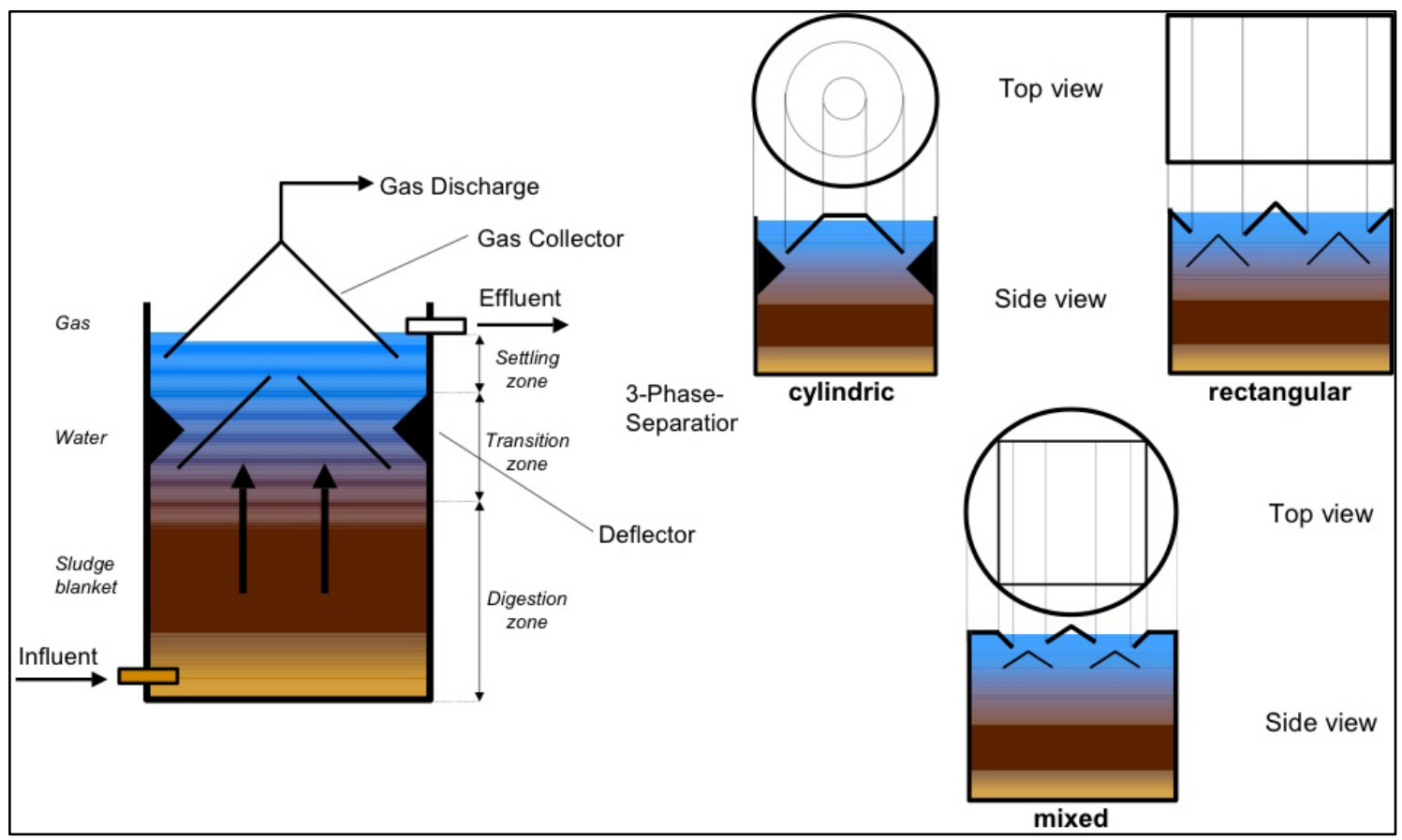

Figure 1.3. Schematic representation of an UASB reactor and its configurations (TBW, 2001). 
These dense aggregates tend to have very good settling properties and are nor susceptible to washout from the system under proper reactor conditions. Therefore, retention of the sludge enables good treatment performance. Natural turbulence, caused by the influent flow and the biogas production provides good mixing, which enables good wastewater-biomass contact. What is more, in the same time high grade energy is produced as biogas. UASB reactor consists of the following sections: sludge bed or blanket, in which all biological processes take place and Gas-Liquid-Solid (GLS) separator, which is the most characteristic part of UASB systems (figure 1.3). It is located at the top of the reactor, which enables to recover elevated solids back to the reaction zone, while the produced bubbles of biogas are collected. Therefore UASB reactor acts as a primary clarifier, a bioreactor and a sludge digester combined. Figure 1.3 shows the details of UASB design and construction configurations (Buntner, 2013).

\subsubsection{UASB reactors in low-strength wastewater treatment}

Historically, anaerobic processes have been mainly employed for industrial (food processing, pulp and paper, textile, chemical, pharmaceutical, petroleum, tannery, and manufacturing industries) or high strength wastewater treatment while less employed for municipal wastewater treatment. This may mainly due to two issues. The first one is the difficulty in retaining slow-growth anaerobic microorganisms with short hydraulic retention time (HRT) associated with treatment of lowstrength wastewater like municipal wastewater. The second one is that anaerobic effluents rarely meet discharge standards for wastewater reuse due to the kinetic limitations of anaerobic metabolism (Herrera-Robledo et al., 2010; Lim and Kim, 2014; Lin et al., 2013).

In many tropical countries, UASB reactor technology offers a simple and effective way of reducing organic pollutant emissions. UASB technology for domestic wastewater treatment has been implemented in many regions, e.g. India, Pakistan, China, Columbia, Brazil, Mexico, Indonesia and Egypt (Hulshoff Pol et al., 1998).

Anaerobic biomass has very low biomass yield, therefore one of the goals of anaerobic treatment is to maintain a long SRT because of the slow growth rate of anaerobic microorganisms, especially when operating at psychrophilic conditions and with low strength wastewater, such as municipal wastewater (van Lier et al., 2001). However, at low temperatures the growth rate of these microorganisms, the chemical oxygen demand (COD) removal rate and methane $\left(\mathrm{CH}_{4}\right)$ production rate diminish (Latif et al., 
2011; Dhaked et al., 2010).

It is also important to consider dissolved methane gas in the effluent of anaerobic treatment of municipal wastewaters and is not usually recovered, which results in greenhouse gas emission from the anaerobic treatment process and loss of a potential energy resource (Urban et al., 2007). This loss is enhanced at lower temperatures because of the increase in $\mathrm{CH}_{4}$ solubility at psychrophilic conditions (Bandara et al., 2011). Thus, it is the case with the anaerobic treatment of municipal wastewaters at low temperatures.

For this reason, it is important to avoid any loss of anaerobic biomass with the treated water that could diminish the capacity of the anaerobic reactor for treating wastewater. Anaerobic membrane technology brings together the advantages of anaerobic processes with the production of solid free effluent, which provides an appropriate alternative to complete biomass retention, enabling an independent control of the hydraulic residence time (HRT) and the solid retention time (SRT) (van Lier et al., 2001), and is a viable technology for the treatment of municipal wastewater at psychrophilic conditions in cold countries (Smith et al., 2013, 2015).

\subsection{Membrane Bioreactors (MBR)}

Membrane bioreactors (MBRs) are combined systems that include a bioreactor and a filtration unit (usually an ultrafiltration or microfiltration membrane). Membrane bioreactor technology has gained novel popularity in the field of wastewater treatment and was widely introduced for industrial application in the early 1990s. It is characterised by numerous advantages compared to conventional activated sludge (AS) processes (di Bella et al., 2010; Ferraris et al., 2009).

The MBR technology offers advantages in terms of reduced footprint, capacity of handling wide fluctuations in influent quality and improved effluent quality. Since membranes work well with aerobic processes, could be improved by working at anaerobic conditions. This is of particular interest for anaerobic processes that depend on the retention of a large population of slow growing microorganisms.

The combination of membrane separation technology and an anaerobic bioreactor may allow for a sustainable municipal wastewater treatment with complete biomass retention, the added benefits of lower sludge production, enhanced high quality effluent, net energy production, and without the extra costs for aeration associated with the 
aerobic treatment processes (Baek et al., 2010; Harada et al., 1994; Lew et al., 2009; Nagata et al., 1989).

AnMBR technology is becoming increasingly popular for municipal wastewater treatment in recent years (An et al., 2009; Lew et al., 2009; Nagata et al., 1989), and can also play a key role in energy recovery due to their capacity to produce $\mathrm{CH}_{4}$ from the utilisation of a large fraction of organics in wastewaters (Sutton et al., 2011). AnMBRs can convert up to $98 \%$ of the influent COD into biogas (Van Zyl et al., 2008); moreover, due to the low growth yield of anaerobic micro-organisms, very small sludge production is normally observed in these systems (Van Zyl et al., 2008). The composition of the biogas produced from AnMBR appears to be: $70-90 \% \mathrm{CH}_{4}, 3-15 \%$ $\mathrm{CO}_{2}$ and $0-15 \% \mathrm{~N}_{2}$ (Lin et al., 2011).

\subsection{AnMBRs Configurations}

AnMBR is defined as an anaerobic bioreactor coupled with membrane filtration. The membrane filtration component can exist in three configurations (Fig. 1.4): (a) internal submerged membrane, (b) external submerged membrane or (c) external cross-flow membrane (Liao et al., 2006). In an internal submerged membrane configuration, membranes are submerged directly into the suspended biomass in the bioreactor and permeate is produced by exerting a vacuum on the membrane. Alternatively, membranes may be located in an external chamber separate from the main bioreactor, but are still submerged in suspended biomass and are operated under vacuum. In such an external submerged configuration, suspended biomass from the bioreactor is pumped to the external chamber, while retentate is returned to the main bioreactor. This configuration facilitates membrane cleaning and replacement by allowing isolation of the membrane unit in an external chamber. This separation enables anaerobic conditions to be maintained in the main bioreactor during membrane cleaning or replacement. In an external cross-flow configuration, the membrane unit is separate from the bioreactor and the membranes operate under pressure to produce permeate. Suspended anaerobic biomass maintained in the bioreactor is pumped into the membrane unit creating a positive pressure that leads to permeate production. The rejected biomass or retentate is returned to the bioreactor. 


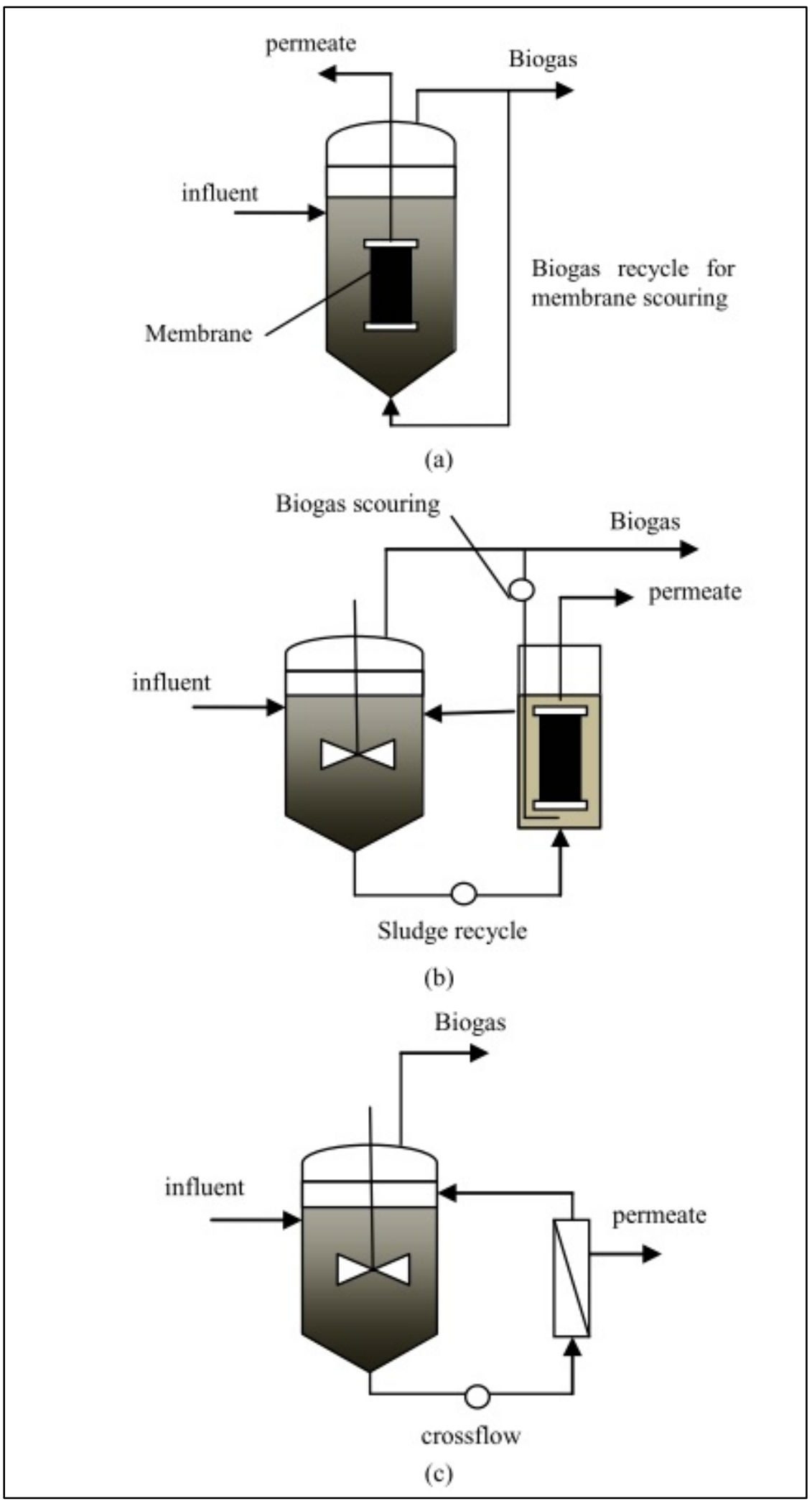

Figure 1.4. Different AnMBR system configurations: (a) internal submerged membrane; (b) external submerged membrane; (c) external cross-flow membrane (Adapted from Chang, 2014). 


\subsubsection{Advantages and Disadvantages of AnMBR}

The advantages offered by this process over conventional anaerobic systems and aerobic MBR are widely recognized (Aquino et al., 2006; He et al., 2005; Liao et al., 2006; Lin et al., 2009). Table 1.2 presents the comparison of conventional aerobic treatment, anaerobic treatment, aerobic MBR and AnMBR. It is apparent from Table 1.2 that AnMBR technology combined the advantages of anaerobic treatment and MBR technology. The advantages that stand out more in the anaerobic membrane technology, apart from those in the table 1.2 are: total biomass retention, excellent effluent quality, low sludge production, a small footprint and net energy production (Lin et al., 2013). 
Table 1.2. Comparison of conventional aerobic treatment, anaerobic treatment, aerobic MBR and AnMBR (Lin et al., 2013).

\begin{tabular}{|c|c|c|c|c|}
\hline Feature & $\begin{array}{l}\text { Conventional aerobic } \\
\text { treatment }\end{array}$ & $\begin{array}{l}\text { Conventional anaerobic } \\
\text { treatment }\end{array}$ & Aerobic MBR & AnMBR \\
\hline Organic removal efficiency & High & High & High & High \\
\hline Organic loading rate & Moderate & High & High to moderate & High \\
\hline Sludge production & High & Low & High to moderate & Low \\
\hline Biomass retention & Low to moderate & Low & Total & Total \\
\hline Nutrient requirement & High & Low & High & Low \\
\hline Alkalinity requirement & Low & High for certain industrial stream & Low & High to moderate \\
\hline Energy requirement & High & Low & High & Low \\
\hline Mode of treatment & Total & Essentially pre-treatment & Total & Total or pre-treatment \\
\hline
\end{tabular}




\subsection{Fundamentals of Membrane Processes}

A number of membrane configurations are commercially available, including hollow fibre (both reinforced and non-reinforced), flat sheet and tubular. The differences between each of these types of membranes are significant. They include pore size, construction materials, chemical cleaning, air-scour requirements, hydraulic configuration and membrane tank volume. A complete retention of all microorganisms in the bioreactor can be achieved in MBRs by the use of microfiltration (MF) or ultrafiltration (UF) modules (Fig. 1.5) (Ferrero, 2011).

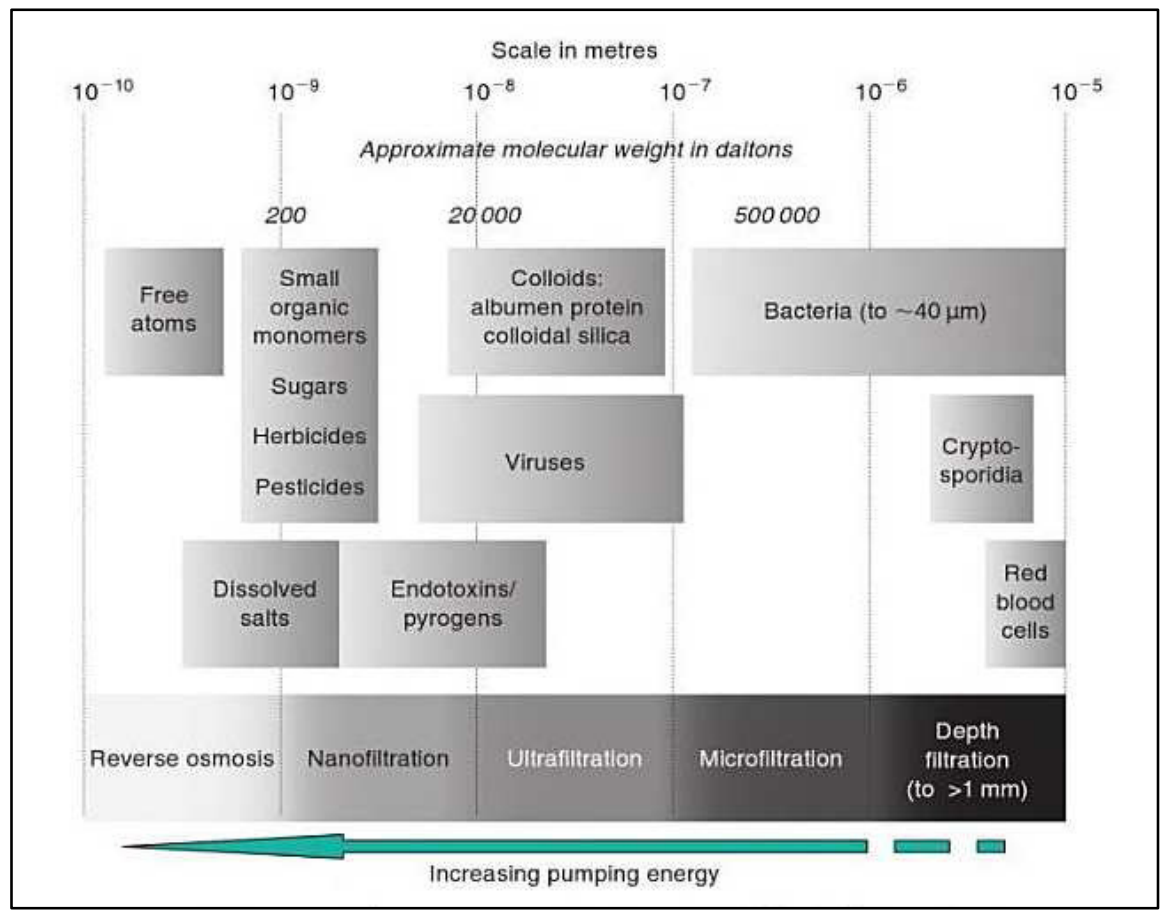

Figure 1.5. Membrane separation processes (Judd and Jefferson, 2003).

\subsubsection{Membrane Materials}

The membrane materials can be classified into three major categories: polymeric, metallic and inorganic (ceramic). However, ceramic or metallic membranes are much more expensive than polymeric membranes. As economics of a system was gradually becoming a great concern, polymeric membranes gained more interests in both research community and commercial applications in recent years. The preferred polymeric membrane materials are polyvinylidene difluoride (PVDF) and polyethersulfone (PES), which account for around $75 \%$ of the total products on the market including 9 out of the 
11 most commercially important products. Other polymeric materials, such as polythylene (PE), polypropylene (PP) and polysulfone (PSF), are also used for some cases of AnMBR applications. Most membrane modules used in AnMBRs are implemented by using MF or UF membranes, with the configuration of either hollow fiber, flat sheet (plate or frame) or tubular. Due to their high packing density and cost efficiency, hollow fiber membrane modules are most popularly used in Anaerobic Submerged Membrane Bioreactors (AnSMBRs) (Lin et al., 2013).

\subsubsection{Operational Parameters}

When working with an MBR some very important and useful parameters have to be monitored. These parameters are listed below (Sales, 2011):

- Flux (J): Quantity of material passing through a unit area of membrane per unit of time, in SI units $\mathrm{m}^{3} \cdot \mathrm{m}^{-2} \cdot \mathrm{s}^{-1}$, but more commonly expressed as $\mathrm{L} \cdot \mathrm{m}^{-2} \cdot \mathrm{h}^{-1}$ $(\mathrm{LMH})$.

$$
\boldsymbol{F l u x}=\frac{\text { flow }\left(\mathrm{m}^{3} / \mathrm{s}\right)}{\text { surface }\left(\mathrm{m}^{2}\right)}
$$

- Transmembrane pressure (TMP): This is defined as the existing pressure drop (or difference) between the membrane pressure at the sludge side and the pressure at the permeate side, and it is the driving force behind the biomass separation process (mbar).

- Membrane Permeability (K): This is calculated as permeate flux per unit of TMP and is usually given as $\mathrm{LMH} \cdot \mathrm{mbar}^{-1}$.

$$
\text { Permability }=\frac{f l u x}{T M P}=\left[L M H . \text { bar }^{-1}\right]
$$

- Membrane Resistance ( $\left.\mathbf{R}_{\mathbf{M}}\right)$ : This is inversely related to permeability and fluid viscosity; it includes membrane resistance, the resistance of the cake layer or biofilm (reversible fouling) and resistance due to pore blocking or adsorption (irreversible fouling) $\left(\mathrm{m}^{-1}\right)$.

$$
\boldsymbol{R}_{M}=\frac{T M P}{J \mu}=\left[m^{-1}\right]
$$


- Specific aeration demand (SADm): This is the air (aerobic reactors) or biogas (anaerobic reactors) flow necessary for the physical cleaning of membranes. It can be expressed as air or biogas flow per membrane unit area (SADm, $\left.\mathrm{m}^{-1}\right)$.

$$
\boldsymbol{S A D m}=\frac{\text { air or biogas flow }\left(\mathrm{m}^{3} / h\right)}{\text { surface }\left(\mathrm{m}^{2}\right)}=\left[m h^{-1}\right]
$$

\subsubsection{Membrane Fouling Issues}

Membrane fouling remains the critical obstacle limiting the more widespread application of AnMBR in wastewater treatment. Membrane fouling could decrease system productivity, cause frequent cleaning which might reduce the membrane lifespan and result in higher replacement costs, and increase the energy requirement for sludge recirculation or gas scouring. Membrane fouling results from interaction between the membrane material and the components of sludge suspension. Membrane fouling is one of the main disadvantages of MBRs, because it hinders the operation of the systems in a constant, reliable way. Although the deposition of solids on AnMBR membrane surfaces is lower than on aerobic MBR membrane surfaces, as AnMBRs are usually operated at lower membrane permeate fluxes, AnMBRs are characterised by lower sludge filterabilities, which favour membrane fouling (Skouteris et al., 2012).

\subsubsection{Membrane Fouling Classification}

Membrane fouling continues to be a substantial challenge in advancing AnMBR technology considering membrane material costs and energy demands associated with fouling prevention. Membrane fouling has been controlled through various strategies, which are linked to the membrane configuration. In external cross-flow configurations, a high cross-flow velocity is maintained to limit inorganic and organic foulant build up on the membrane. In submerged configurations, fouling control is typically accomplished through biogas sparging, backflushing, and/or membrane relaxation (Smith et al., 2012).

The factors affecting membrane fouling can be classified into four groups: membrane module characteristics, biomass characteristics, feed water characteristics and operating conditions (Fig. 1.6). The complex interactions between these factors complicate understanding of the issue. The fouling behaviour is directly determined by sludge 
characteristics and hydrodynamic conditions. However, operating conditions (i.e., SRT, HRT and $\mathrm{F} / \mathrm{M}$ ) and feedwater have an indirect effect on membrane fouling by modifying sludge characteristics (Meng et al., 2009).

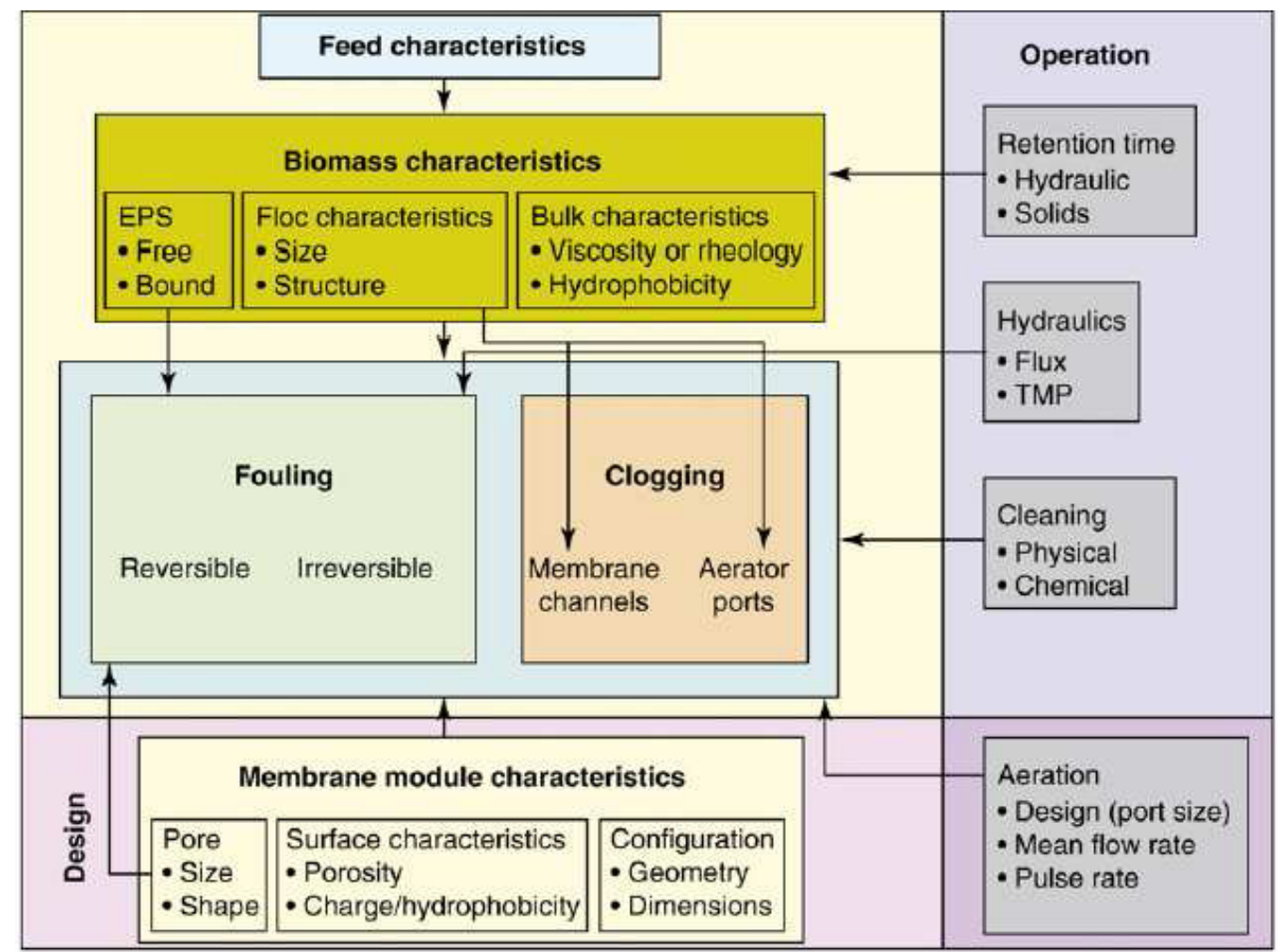

Figure 1.6. Main factors affecting membrane fouling (Judd, 2006).

Based on their relative contributions of foulant components to the total membrane fouling, several membrane fouling mechanisms, including pore plugging/clogging by colloidal particles, adsorption of soluble compounds and biofouling, deposition of solids as a cake layer, cake layer consolidation and the spatial and temporal changes of the foulant composition during the long-term operation, have been proposed (Lin et al., 2013).

Zhang et al., (2006), describes in the fig. 1.7 a three stage history for membrane fouling:

(i) Stage 1: an initial short term rise in TMP due to 'conditioning';

(ii) Stage 2: long-term rise in TMP, either linear or weakly exponential;

(iii) Stage 3: a sudden rise in TMP, with a sharp increase in dTMP/dt, also known as the TMP jump. 
The stages 2 and 3 behaviors are typified in the literature by the results of previous studies. When operating at fluxes well below the apparent critical flux of the mixed liquor suspended solids, a slow steady rise in TMP (stage 2) was observed which eventually changed to a rapid rise in TMP (stage 3). For sustainable operation the aim would be to limit the extent of stage 1, prolong stage 2 and avoid stage 3 since it could be difficult to restore.

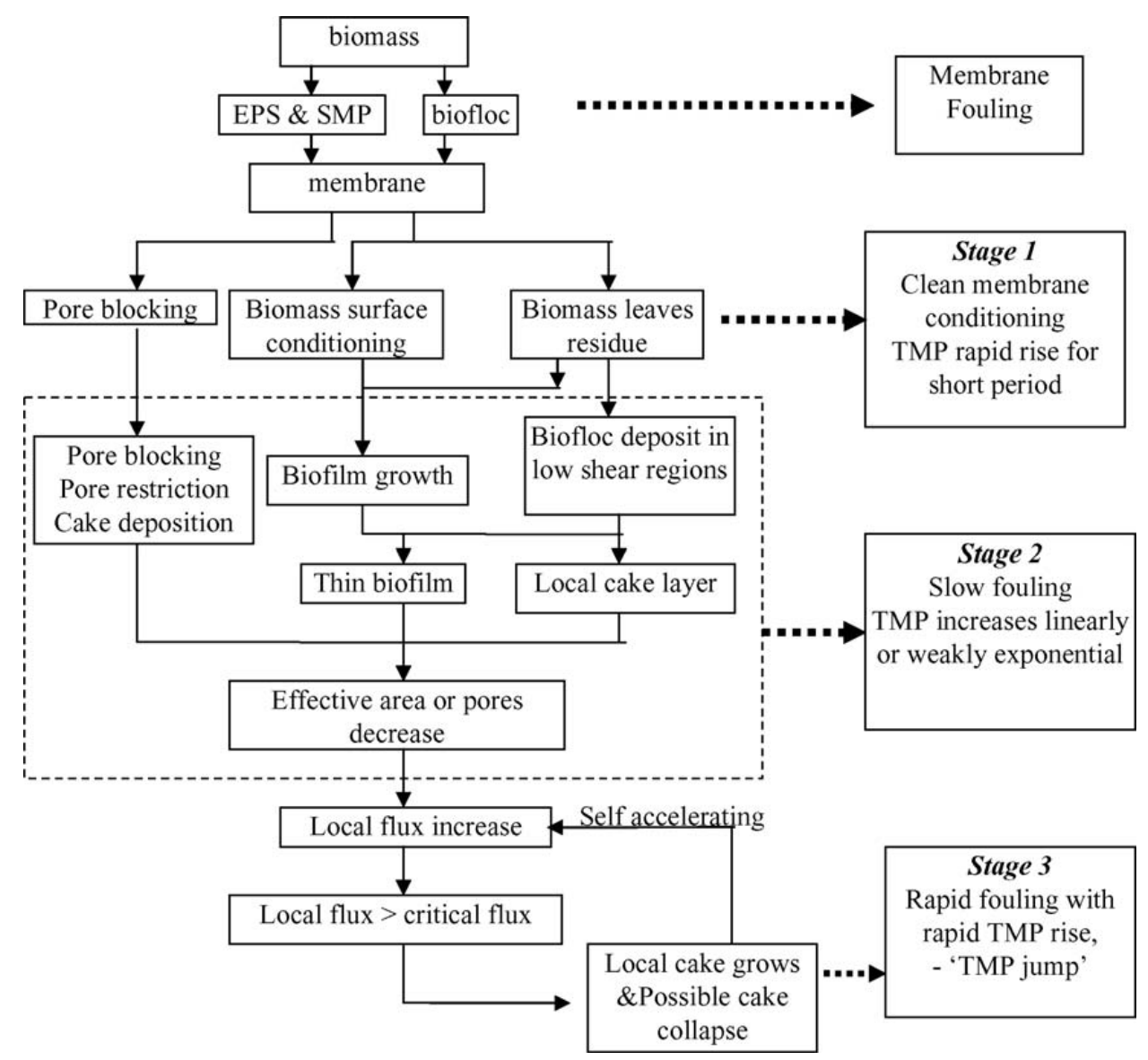

Figure 1.7. MBR fouling mechanism map. The three stages of fouling (Zhang et al., 2006).

Other parameters like HRT, OLR, SRT and $\mathrm{pH}$ indirectly affect membrane fouling and it's expected that the higher MLSS, OLR, residual COD and SMP production in AnMBR will cause more serious membrane fouling. Membrane fouling can be traditionally classified into reversible and irreversible fouling based on the cleaning practice, although their definitions were not consistent in the literatures (Lin et al., 2013). Meng et al., (2009) proposed reversible fouling into removable fouling and irremovable fouling. Removable fouling refers to fouling that can be removed by 
physical means such as backwash or relaxation under cross flow conditions, while irremovable fouling refers to fouling needed to be removed by chemical cleaning. The irreversible fouling is a permanent fouling which cannot be eliminated by any cleaning approaches. In general, removable fouling occurs due to loose external deposition of material. In contract, irremovable fouling is caused by the pore blocking and strongly attached foulants during membrane filtration. Membrane fouling can also be classified into biological, organic and inorganic fouling in viewpoint of the foulant components. Biological fouling is specifically related to the interaction of biomass with the membrane. Membrane fouling appears to start from pore clogging caused by cell debris and colloidal particles. Organic and inorganic fouling usually respectively refers to macromolecular species (biopolymers) and scalants (Lin et al., 2013). Organic fouling refers to the deposition of biopolymers (i.e., proteins and polysaccharides) on the membranes.

Due to their small size, biopolymers can be deposited on the membranes more readily as a result of permeate flow, but compared to large particles (e.g., colloids and sludge flocs) they have lower back transport velocity due to lift forces. Inorganic fouling can form in two ways: through chemical precipitation and biological precipitation. A great number of cations and anions such as $\mathrm{Ca}^{2+}, \mathrm{Mg}^{2+}, \mathrm{Al}^{3+}, \mathrm{Fe}^{3+}, \mathrm{CO}_{3}{ }^{2-}, \mathrm{SO}_{4}{ }^{2-}, \mathrm{PO}_{4}{ }^{3-}, \mathrm{OH}^{-}$ and others are present in an MBR. Concentration polarisation will lead to higher concentration of retained salts on the membrane surface. Chemical precipitation occurs when the concentration of chemical species exceeds saturation concentration due to this polarisation. Biological precipitation is another contributory factor in inorganic fouling. The biopolymers contain ionisable groups such as $\mathrm{COO}^{-}, \mathrm{CO}_{3}{ }^{2-}, \mathrm{SO}_{4}{ }^{2-}, \mathrm{PO}_{4}{ }^{3-}, \mathrm{OH}^{-}$, and metal ions can be easily captured by these negative ions. In some cases, calcium and acid functional groups $(\mathrm{R}-\mathrm{COOH})$ can form complexes and build a dense bio-cake or gel layer that may exacerbate flux decline.

When comparing Aerobic membrane bioreactor (AeMBR) and AnMBR studies, lower permeate fluxes are typically observed in AnMBRs potentially as a result of less flocculation and thus increased concentrations of fine particulates and colloidal solids at the membrane surface. However, direct comparison studies between AeMBRs and AnMBRs for domestic wastewater (DWW) treatment have indicated similar fouling potential or less propensity for fouling in AnMBRs. Fouling control represents the most intensive energy demand associated with AnMBR treatment, and therefore, reducing 
this demand is central to maximizing the potential energy recovery. Considering the low organic strength of DWW and correspondingly low potential biogas generation, minimizing energy demands associated with fouling control is likely necessary to achieve energy neutral or positive operation (Smith et al., 2012).

\subsection{Membrane Cleaning}

As consequence of membrane fouling, the flux decrease and to maintain the membrane in operation is necessary to clean. There are distinct cleaning methods and can be various depending on the nature of fouling. Membrane cleaning can either be done physically or chemically. Detailed discussion of these conventional cleaning techniques can be found in the Chapter 7 .

\subsubsection{Physical cleaning}

Physical cleaning is closely related to membrane operation such as regular backwash, relaxation or short term increase in shear rate to remove the cake layer accumulated on the membrane surface. In addition, membranes can also be physically removed from the membrane tank to be cleaned ex situ, e.g. by applying water jets. Cake layer formation on the membrane surface was found to play the major role in the increase of membrane resistance and decrease of flux in AnMBRs (Jeison and van Lier, 2006).

\subsubsection{Chemical cleaning}

When the above-mentioned cleaning methods are not effective enough to reduce the fouling to an acceptable level, it is necessary to clean the membranes chemically. Many chemical cleaning agents, such as sodium hypochlorite $(\mathrm{NaClO})$, hydrochloric acid $(\mathrm{HCl})$, nitric acid, citric acid, sodium hydroxide $(\mathrm{NaOH})$ and ethylenediaminetetraacetic (EDTA), have been frequently employed for membrane cleaning in AnMBRs. Efficient chemical cleaning requires the selection of cleaning agents that target dominant compounds responsible for fouling and that do not adversely affect the membrane itself. In general, oxidizing and alkaline agents, such as $\mathrm{NaClO}$ and $\mathrm{NaOH}$, are used to remove the microorganisms and organic foulants. Acidic agents are effective in breaking metalassociated structures including metal organic foulant complexation and inorganic scales (Lin et al., 2013). 


\subsection{Other methods for controlling membrane fouling}

\subsubsection{Coagulant/Flocculants}

Due to the back transport and shear induced fouling control mechanisms, large microbial flocs are expected to have a lower impact on membrane fouling. Based on this expectation, studies have explored addition of coagulants such alum (Holbrook et al., 2004), ferric chloride, zeolite (Lee et al., 2001), etc. and have shown permeability enhancement. Pre-treatment of the effluent is also possible and studies based on the pre-coagulation/sedimentation of effluent before its introduction in the bioreactor revealed the fouling limitation offered by this technique (Itonga and Watanabe, 2004; Le-Clech et al., 2006).

\subsubsection{Adsorbent/Flux Enhancers}

Lower fouling propensity is observed in MBR processes when biomass is mixed with adsorbents in that addition of adsorbents into biological treatment systems decreases the level of pollutants, and more particularly organic compounds (Kim and Lee, 2003; Lesage et al., 2005; Li et al., 2005; $\mathrm{Ng}$ et al., 2006). In view of saturation of PAC (Powdered Activated Carbon) during long term studies, researchers have suggested periodic addition of PAC (Ng et al., 2005; Fang et al., 2006). Certain studies have proposed pre-flocculation and PAC addition (Guo et al., 2004; Cao et al., 2005).

A cationic polymer-based membrane performance enhancer (MPE50) has been commercialized by NALCO. The interaction between the polymer and the soluble organics was reported as the main mechanism responsible for performance enhancement (Yoon et al., 2005). The potential impacts of coagulants or adsorbents on biomass community or biomass metabolism need to be taken into account (Iversen et al., 2009), and the discharge of some chemicals that are used as coagulants or adsorbents might be a potential environmental risk. 


\subsection{References}

Aiyuk, S., Forrez, I., Lieven, D.K., van Haandel, A., Verstraete, W., 2006. Anaerobic and complementary treatment of domestic sewage in regions with hot climates $-\mathrm{A}$ review. Bioresour. Technol. 97, 2225-2241.

An, Y., Wang, Z., Wu, Z., Yang, D., Zhou, Q., 2009. Characterization of membrane foulants in an anaerobic non-woven fabric membrane bioreactor for municipal wastewater treatment. Chem. Eng. J. 155, 709-715.

Aquino, S.F., Hu, A.Y., Akram, A., Stuckey, D.C., 2006. Characterization of dissolved compounds in submerged anaerobic membrane bioreactors (SAMBRs). J. Chem. Technol. Biotechnol. 81, 1894-1904.

Baek, S.H., Pagilla, K.R., 2006. Aerobic and anaerobic membrane bioreactors for municipal wastewater treatment. Water Environ. Res. 78, 133-140.

Baek, S.H., Pagilla, K.R., Kim, H.-J., 2010. Lab-scale study of an anaerobic membrane bioreactor (AnMBR) for dilute municipal wastewater treatment. Biotechnol. Bioprocess Eng. 15, 704-708.

Bandara, W.M.K.R.T.W., Kindaichi, T., Satoh, H., Sasakawa, M., Nakahara, Y., Takahashi, M., Okabe, S., 2012. Anaerobic treatment of municipal wastewater at ambient temperature: Analysis of archaeal community structure and recovery of dissolved methane. Water Res. 46, 5756-5764.

Bandara, W.M.K.R.T.W., Satoh, H., Sasakawa, M., Nakahara, Y., Takahashi, M., Okabe, S., 2011. Removal of residual dissolved methane gas in an upflow anaerobic sludge blanket reactor treating low-strength wastewater at low temperature with degassing membrane. Water Research 45 (11), 3533-3540.

Bitton, G., 2010. Wastewater Microbiology. Wiley-Lis, John Wiley and Sons, New Jersey, USA.

Buntner, D., 2013. Combined UASB-MBR system for the treatment of low-strength wastewater at ambient temperatures. Universidade de Santiago de Compostela. 
Cao, J.H., Zhu, B.K., Lu, H., Xu, Y.Y., 2005. Study on polypropylene hollow fiber based recirculated membrane bioreactor for treatment of municipal wastewater. Desalination 183:431-438.

Chan, Y.J., Chong, M.F., Law, C.L., Hassell, D.G., 2009. A review on anaerobicaerobic treatment of industrial and municipal wastewater. Chem. Eng. J. 155, 118.

Chang, S., 2014. Anaerobic Membrane Bioreactors (AnMBR) for Wastewater Treatment. Adv. Chem. Eng. Sci. 04, 56-61.

Chu, H.P., Li, X.Y., 2005. Membrane fouling in a membrane bioreactor (MBR): Sludge cake formation and fouling characteristics. Biotechnol. Bioeng. 90, 323-331.

Dhaked, R.K., Singh, P., Singh, L., 2010. Biomethanation under psychrophilic conditions. Waste Management 30 (12), 2490-2496.

di Bella, G., Durante, F., Torregrossa, M., Viviani, G., 2010. Start-up with or without inoculum? Analysis of an SMBR pilot plant. Desalination 260, 79-90.

Fang, H.H.P., Shi, X., Zhang, T., 2006. Effect of activated carbon on fouling of activated sludge filtration. Desalination 189:193-199.

Fernández, T., Grau, P., Beltrán, S., Ayesa, E, 2011. Integrated simulation of mass and energy for optimising operational strategies in WWTPs. Proceedings in the 8th IWA Symposium on Systems Analysis and Integrated Assessment (Watermatex 2011). 20-22 June, Donostia-San Sebastián, Spain.

Ferraris, M., Innella, C., Spagni, A., 2009. Start-up of a pilot-scale membrane bioreactor to treat municipal wastewater. Desalination 237, 190-200.

Ferrero, G., 2011. Development of an air-scour control system for membrane bioreactors. Universitat de Girona, Laboratori d'Enginyeria Química i Ambiental.

Gao, D.-W., Hu, Q., Yao, C., Ren, N.-Q., 2014. Treatment of domestic wastewater by an integrated anaerobic fluidized-bed membrane bioreactor under moderate to low temperature conditions. Bioresour. Technol. 159, 193-198. 
Giménez, J.B., Martí, N., Ferrer, J., Seco, A., 2012. Methane recovery efficiency in a submerged anaerobic membrane bioreactor (SAnMBR) treating sulphate-rich urban wastewater: evaluation of methane losses with the effluent. Bioresour. Technol. 118, 67-72.

Grant, S.B., Ambrose, R.F., Deletic, A., Brown, R., Jiang, S.C., Rosso, D., Cooper, W.J., Marusic, I., Saphores, J.D., Feldman, D.L., Hamilton, A.J., Fletcher, T.D., Cook, P.L.M., Stewardson, M., Sanders, B.F., Levin, L.A., 2012. Taking the "waste" out of "wastewater" for human water security and ecosystem sustainability. Science 337, 681-686.

Guo, W.S., Vigneswaran, S., Ngo, H.H., 2004. A rational approach in controlling membrane fouling problems: Pretreatments to a submerged hollow fiber membrane system. In: Proceedings of the Water Environment-Membrane Technology Conference. Seoul, Korea, 7-10 June. London: IWA Publishing.

Harada, H., Momonoi, K., Yamazaki, S., Takizawa, S., 1994. Application of anaerobicUF membrane reactor for treatment of a wastewater containing high strength particulate organics, in: Water Science and Technology. pp. 307-319.

He, Y., Xu, P., Li, C., Zhang, B., 2005. High-concentration food wastewater treatment by an anaerobic membrane bioreactor. Water Res. 39, 4110-4118.

Herrera-Robledo, M., Morgan-Sagastume, J.M., Noyola, A., 2010. Biofouling and pollutant removal during long-term operation of an anaerobic membrane bioreactor treating municipal wastewater. Biofouling 26, 23-30.

Ho, J., Khanal, S.K., Sung, S., 2007. Anaerobic membrane bioreactor for treatment of synthetic municipal wastewater at ambient temperature. Water Sci. Technol. 55, 79-86.

Holbrook, R.D., Higgins, M.J., Murthy, S.N., et al. 2004. Effect of alum addition on the performance of submerged membranes for wastewater treatment. Water Envir. Research 76, 2699-2702. 
Hu, A., Stuckey, D., 2007. Activated Carbon Addition to a Submerged Anaerobic Membrane Bioreactor: Effect on Performance, Transmembrane Pressure, and Flux. J. Environ. Eng. 133, 73-80.

Huang, X., Wei, C.H., Yu, K.C., 2008. Mechanism of membrane fouling control by suspended carriers in a submerged membrane bioreactor. J. Memb. Sci. 309, 7-16.

Hulshoff Pol L., Euler H., Schroth S., Wittur T., Grohganz D. (1998). Proc. of 5th Latin Water Rese American Seminar on Anaerobic Wastewater Treatment, Oct. 27-30, 1998, Vina del Mar, Chile

Itonga, T. and Watanabe, Y., 2004. Performance of membrane bioreactor combined with pre-coagulation/sedimentation. Water Science and Technology: Water Supply 4 (1):143-149.

Iversen, V., Koseoglu, H., Yigit, N.O., et al. 2009. Impacts of membrane flux enhancers on activated sludge respiration and nutrient removal in MBRs. Water Research 43: $822-830$.

Jeison, D., van Lier, J.B., 2006. Cake layer formation in anaerobic submerged membrane bioreactors (AnSMBR) for wastewater treatment. J. Memb. Sci. 284, $227-236$.

Judd, S., 2006. The MBR Book Principles and Applications of Membrane Bioreactors for Water and Wastewater Treatment, 1st ed. Elsevier B.V.

Judd, S., Jefferson, B., 2003. Membranes for Industrial wastewater recovery and re-use. Elsevier Advanced Technology, The Boulevard, Langford Lane, Kidlington.

Kataoka, N., Tokiwa, Y., Tanaka, Y., Fujiki, K., Taroda, H., Takeda, K., 1992. Examination of bacterial characteristics of anaerobic membrane bioreactors in three pilot-scale plants for treating low-strength wastewater by application of the colony-forming-curve analysis method. Appl. Environ. Microbiol. 58, 2751-2757.

Khanal, S.K., 2008. Anaerobic Biotechnology for Bioenergy Production: Principles and Applications. Wiley-Blackwell, Oxford, UK. 
Kim, J., Kim, K., Ye, H., Lee, E., Shin, C., McCarty, P.L., Bae, J., 2011. Anaerobic fluidized bed membrane bioreactor for wastewater treatment. Environ. Sci. Technol. 45, 576-581.

Kim, J.S., and Lee, C.H., 2003. Effect of powdered activated carbon on the performance of an aerobic membrane bioreactor: Comparison between crossflow and submerged membrane systems. Water Environment Research 75: 300-307.

Latif, M.A., Ghufran, R., Wahid, Z.A., Ahmad, A., 2011. Integrated application of upflow anaerobic sludge blanket reactor for the treatment of wastewaters. Water Research 45 (16), 4683-4699.

Le-Clech, P., Chen, V., Fane, T.A.G., 2006. Fouling in membrane bioreactors used in wastewater treatment. Journal of Membrane Science 284:17-53.

Lee, J.C., Kim J.S., Kang, I.J., Cho, M.H., Park, P.K., Lee, C.H., 2001. Potential and limitations of alum or zeolite addition to improve the performance of a submerged membrane bioreactor. Water Science and Technology 43, 59-66.

Lesage, N., Sperandio, M., Cabassud, C., 2005. Performances of a hybrid adsorption/ submerged membrane biological process for toxic waste removal. Water Science and Technology 51:173-180.

Lettinga, G., van Lier, J.B., Van Buuren, J.C.L., Zeeman, G., 2001. Sustainable development in pollution control and the role of anaerobic treatment. Water Sci. Technol. 44, 181-188.

Lew, B., Tarre, S., Beliavski, M., Dosoretz, C., Green, M., 2009. Anaerobic membrane bioreactor (AnMBR) for domestic wastewater treatment. Desalination 243, 251257.

Li, Y.Z., He, Y.L., Liu, Y.H., Yang, S.C., Zhang, G.J., 2005. Comparison of the filtration characteristics between biological powdered activated carbon sludge and activated sludge in submerged membrane bioreactors. Desalination 174:305-314. 
Liao, B.-Q., Kraemer, J.T., Bagley, D.M., 2006. Anaerobic Membrane Bioreactors: Applications and Research Directions. Crit. Rev. Environ. Sci. Technol. 36, 489530.

Lim, S.J., Kim, T.H., 2014. Applicability and trends of anaerobic granular sludge treatment processes. Biomass and Bioenergy 60, 189-202.

Lin, H., Chen, J., Wang, F., Ding, L., Hong, H., 2011. Feasibility evaluation of submerged anaerobic membrane bioreactor for municipal secondary wastewater treatment. Desalination 280, 120-126.

Lin, H., Peng, W., Zhang, M., Chen, J., Hong, H., Zhang, Y., 2013. A review on anaerobic membrane bioreactors: Applications, membrane fouling and future perspectives. Desalination 314, 169-188.

Lin, H.J., Xie, K., Mahendran, B., Bagley, D.M., Leung, K.T., Liss, S.N., Liao, B.Q., 2009. Sludge properties and their effects on membrane fouling in submerged anaerobic membrane bioreactors (SAnMBRs). Water Res. 43, 3827-3837.

Martinez-Sosa, D., Helmreich, B., Netter, T., Paris, S., Bischof, F., Horn, H., 2011. Anaerobic submerged membrane bioreactor (AnSMBR) for municipal wastewater treatment under mesophilic and psychrophilic temperature conditions. Bioresour. Technol. 102, 10377-10385.

Meng, F., Chae, S.-R., Drews, A., Kraume, M., Shin, H.-S., Yang, F., 2009. Recent advances in membrane bioreactors (MBRs): membrane fouling and membrane material. Water Res. 43, 1489-512.

Metcalf \&Eddy, W.E.T. and R., 2003. Metcalf \&Eddy, 4th ed. McGraw Hill.

Molina-Muñoz, M., Poyatos, J.M., Rodelas, B., Pozo, C., Manzanera, M., Hontoria, E., Gonzalez-Lopez, J., 2010. Microbial enzymatic activities in a pilot-scale MBR experimental plant under different working conditions. Bioresour. Technol. 101 (2), 696-704.

Nagata, N., Herouvis, K.J., Dziewulski, D.M., Belfort, G., 1989. Cross-flow membrane microfiltration of a bacteriol fermentation broth. Biotechnol. Bioeng. 34, 447-466. 
Naturgerechte Technologien, Bau- und Wirtschaftsberatung (TBW) GmbH (Editor) (2001). Anaerobic Treatment of Municipal Wastewater in UASB-reactors. GTZ and GATE.

Ng, C.A., Sun, D., Fane, A.G., 2006. Operation of membrane bioreactor with powdered activated carbon addition. Separation Science and Technology 41:1447-1466.

Ng, C.A., Sun, D., Zhang, J., et al. 2005. Strategies to improve the sustainable operation of membrane bioreactors. In: Proceedings of the International Desalination Association World Congress. Singapore, 11-16 September.

Ozgun, H., Kaan, R., Evren, M., Kinaci, C., Spanjers, H., Lier, J.B. Van, 2013. A review of anaerobic membrane bioreactors for municipal wastewater treatment: Integration options, limitations and expectations. Sep. Purif. Technol. 118, 89104.

Rittmann, B.E., McCarty, P.L., 2001. Environmental Biotechnology: Principles and Applications. McGraw-Hill Companies.

Sales, H.M., 2011. Development of a decision support system for the integrated control of membrane bioreactors. Universitat de Girona.

Shannon, M.A., Bohn, P.W., Elimelech, M., Georgiadis, J.G., Mariñas, B.J., Mayes, A.M., 2008. Science and technology for water purification in the coming decades. Nature 452, 301-310.

Skouteris, G., Hermosilla, D., López, P., Negro, C., Blanco, Á., 2012. Anaerobic membrane bioreactors for wastewater treatment: A review. Chem. Eng. J. 198$199,138-148$.

Smith, A.L., Skerlos, S.J., Raskin, L., 2013. Psychrophilic anaerobic membrane bioreactor treatment of domestic wastewater. Water Res. 47, 1655-1665.

Smith, A.L., Skerlos, S.J., Raskin, L., 2013. Psychrophilic anaerobic membrane bioreactor treatment of domestic wastewater. Water Res. 47, 1655-1665. 
Smith, A.L., Skerlos, S.J., Raskin, L., 2015. Anaerobic membrane bioreactor treatment of domestic wastewater at psychrophilic temperatures ranging from $15^{\circ} \mathrm{C}$ to $3^{\circ} \mathrm{C}$. Environ. Sci. Water Res. Technol. 1, 56-64.

Smith, A.L., Stadler, L.B., Love, N.G., Skerlos, S.J., Raskin, L., 2012. Perspectives on anaerobic membrane bioreactor treatment of domestic wastewater: a critical review. Bioresour. Technol. 122, 149-59.

Sutton, P.M., Melcer, H., Schraa, O.J., Togna, A.P., 2011. Treating municipal wastewater with the goal of resource recovery. Water Sci. Technol. 63, 25-31.

Urban, I., Weichgrebe, D., Rosenwinkel, K.H., 2007. Anaerobic treatment of municipal wastewater using the UASB-technology. Water Science and Technology 56 (10), $37-44$.

van Lier, J.B., Tilche, A., Ahring, B.K., Macarie, H., Moletta, R., Dohanyos, M., Pol, L.W., Lens, P., Verstraete, W., 2001. New perspectives in anaerobic digestion. Water Sci. Technol. 43, 1-18.

van Lier, J.B.,2008. High-rate anaerobic wastewater treatment: diversifying from endof-the-pipe treatment to resource-oriented conversion techniques, Water Sci. Technol. 57, 1137-1148.

Van Zyl, P.J., Wentzel, M.C., Ekama, G.A., Riedel, K.J., 2008. Design and start-up of a high rate anaerobic membrane bioreactor for the treatment of a low $\mathrm{pH}$, high strength, dissolved organic waste water. Water Sci. Technol. 57, 291-295.

Yoon, S.H., Collins, J.H., Musale, D., et al. 2005. Effects of flux enhancing polymer on the characteristics of sludge in membrane bioreactor process. Water Science and Technology 51:151-157.

Zhang, J., Chua, H.C., Zhou, J., Fane, A. G., 2006. Factors affecting the membrane performance in submerged membrane bioreactors. J. Memb. Sci. 284, 54-66. 


\section{CHAPTER 2}

\section{Objectives}





\subsection{Main Objectives}

The main objective of this thesis is to study the viability of the anaerobic treatment of municipal wastewater under psychrophilic condition in membrane bioreactor. In this sense, the specific objectives of this thesis are as follows:

$\checkmark$ To assess the long term feasibility of the treatment of municipal wastewater under psychrophilic conditions $\left(18 \pm 2^{\circ} \mathrm{C}\right)$ in a pilot scale AnMBR consisting of an UASB reactor coupled with an ultrafiltration membrane unit and in a pilot scale AnSMBR

$\checkmark$ To study the acclimatization of the sludge.

$\checkmark$ To study the effect of the variables that affect the biological treatment process, such as organic loading rate (OLR), volume loading rate (VLR), and the hydraulic residence time on the performance of the tCOD removal efficiency.

$\checkmark$ To determine the specific production of methane and the production of sludge in anaerobic treatment of urban wastewater.

$\checkmark$ To determine the operating conditions of the membrane and the effect on the biological treatment process.

$\checkmark$ To evaluate the viability of the long-term operation.

$\checkmark$ To determine if the configuration of the membrane affects the biological process and the feasibility of treatment.

$\checkmark$ To evaluate the effectiveness of various cleaning procedures 



\section{CHAPTER 3}

\section{Materials and Methods}





\subsection{Introduction}

The two pilot plants were operated in the University of Valladolid (Department of Chemical Engineering and Environmental Technology). All the technical details concerning the pilot plants are provided in this chapter. Immediately, the elements of the two pilot plants were described.

\subsection{Municipal wastewater}

The UASB reactors were fed with municipal wastewater from the city of Valladolid drawn from a nearby sewer. The water passes through a rotary sieve where the particles with size greater than $0.5 \mathrm{~mm}$ are retained and deposited in a bag, after the water is stored in a tank, fed to a primary settler, and then fed to the reactors.

\subsubsection{Rotary Sieve}

The rotary sieve (0.5 mm mesh) (Model TR-40/25 from TORO ${ }^{\circledR}$ Equipment) (Fig. 3.1) works every six hours during two minutes, to renew the water of the tank and keep feeding the primary settler continuously to feed the reactors with new water.

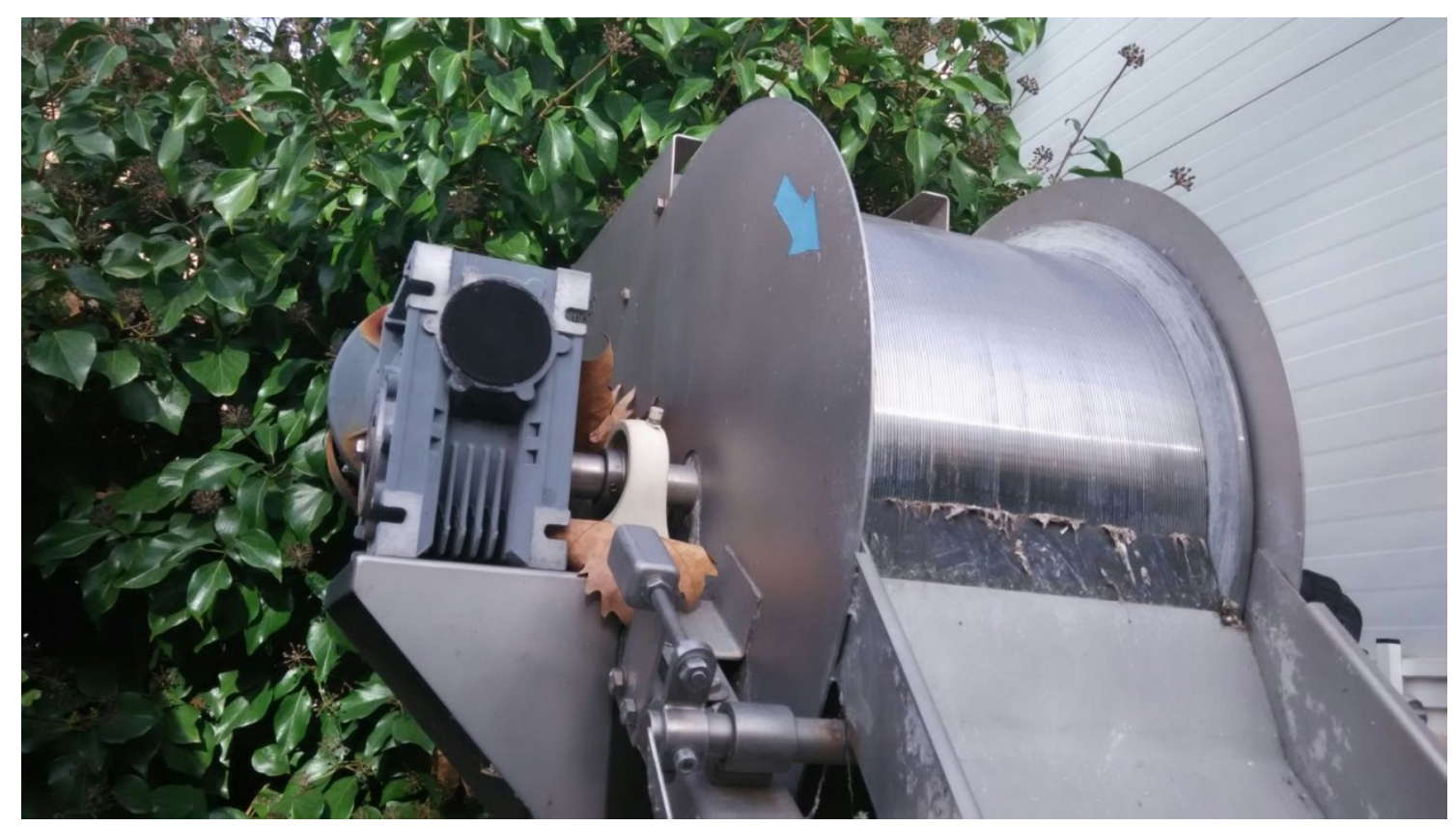

Figure 3.1. Rotary sieve. 


\subsubsection{Primary Settler}

The primary settler made by PVC, with a total volume of $25 \mathrm{~L}$ operating with a HRT between 1 and $3 \mathrm{~h}$ (Fig. 3.2). The settler was equipped with a level meter for when lowering the level for any reason and to prevent entry of air, the two pilot plants will automatically stop. That level meter disconnects the feed pumps, filtration and backwashing pumps of the reactors.
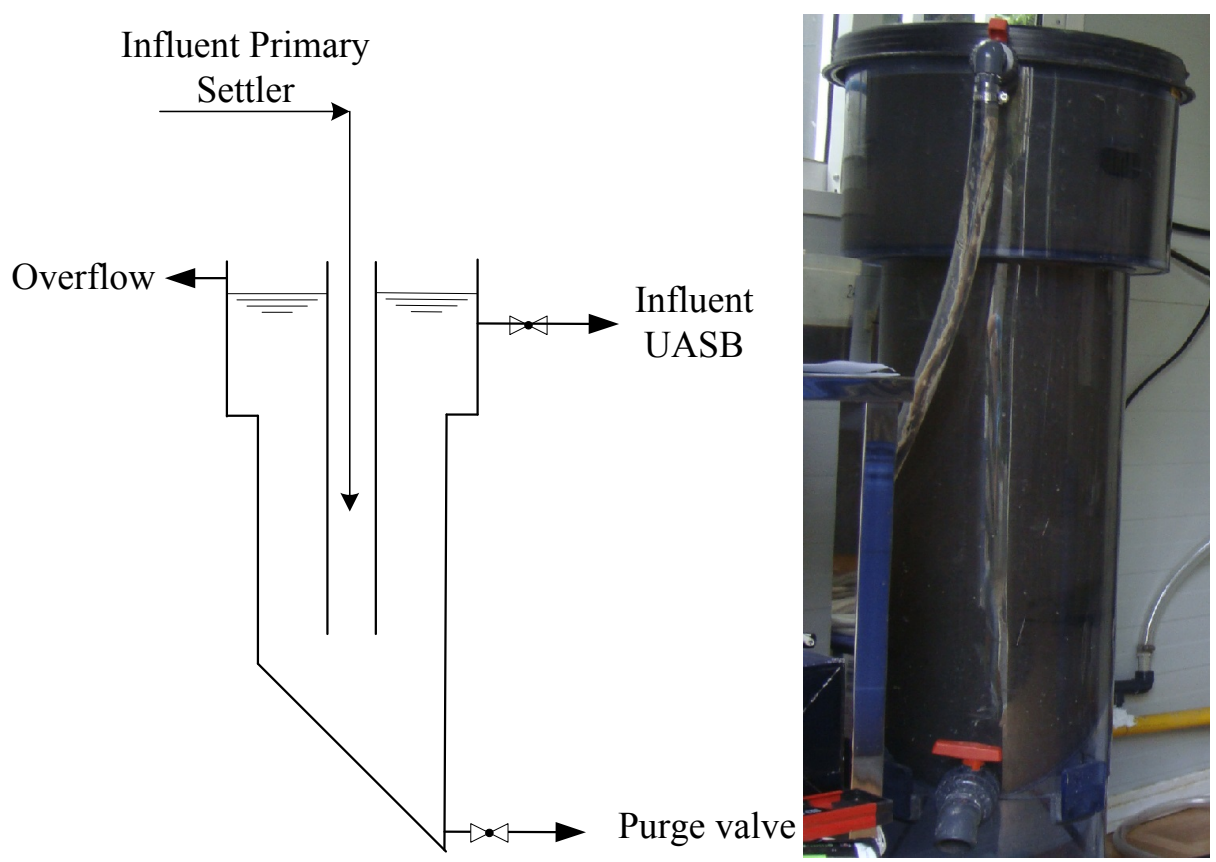

Figure 3.2. Schematic view of the primary settler used during the entire period of operation.

\subsection{General description of the pilot plants}

Two pilot plants were operated with different configuration, in the first one, a UASB reactor coupled to an external membrane tank with one membrane module ZW-10 and the second, a UASB reactor with two modules ZW-10 submerged internally on top of the UASB reactor.

The primary settler, the UASB reactor and the membrane module of both pilot plants were placed in a room provided with an air-conditioning system, in order to maintain the temperature of the UASB reactor at $18 \pm 2^{\circ} \mathrm{C}$ during both winter and summer time. 


\subsubsection{Description of the AnMBR pilot plant}

Fig. 3.3 and 3.4 shows the experimental set up and the AnMBR pilot plant, respectively. The reactor was built on PPH (Polypropylene Homo-Polymer's). The UASB reactor with a volume of $181.7 \mathrm{~L}$ (height $2030 \mathrm{~mm}$, internal diameter $337.6 \mathrm{~mm}$ ) using a useful volume of $160 \mathrm{~L}$. In the top of the UASB reactor there is one internal three-phase separator with a hypotenuse of $20 \mathrm{~cm}$ and an inclination of $47.5^{\circ}$.

The tank membrane is external and built in PPH, with a volume of $162.9 \mathrm{~L}$ (height 1820 $\mathrm{mm}$, internal diameter $337.6 \mathrm{~mm}$ ) using a useful volume of $150 \mathrm{~L}$. The membrane is hung on the top of the membrane tank and with bridle in the bottom to remove the membrane. The membrane is surrounded by a concentric tube that acts as airlift.

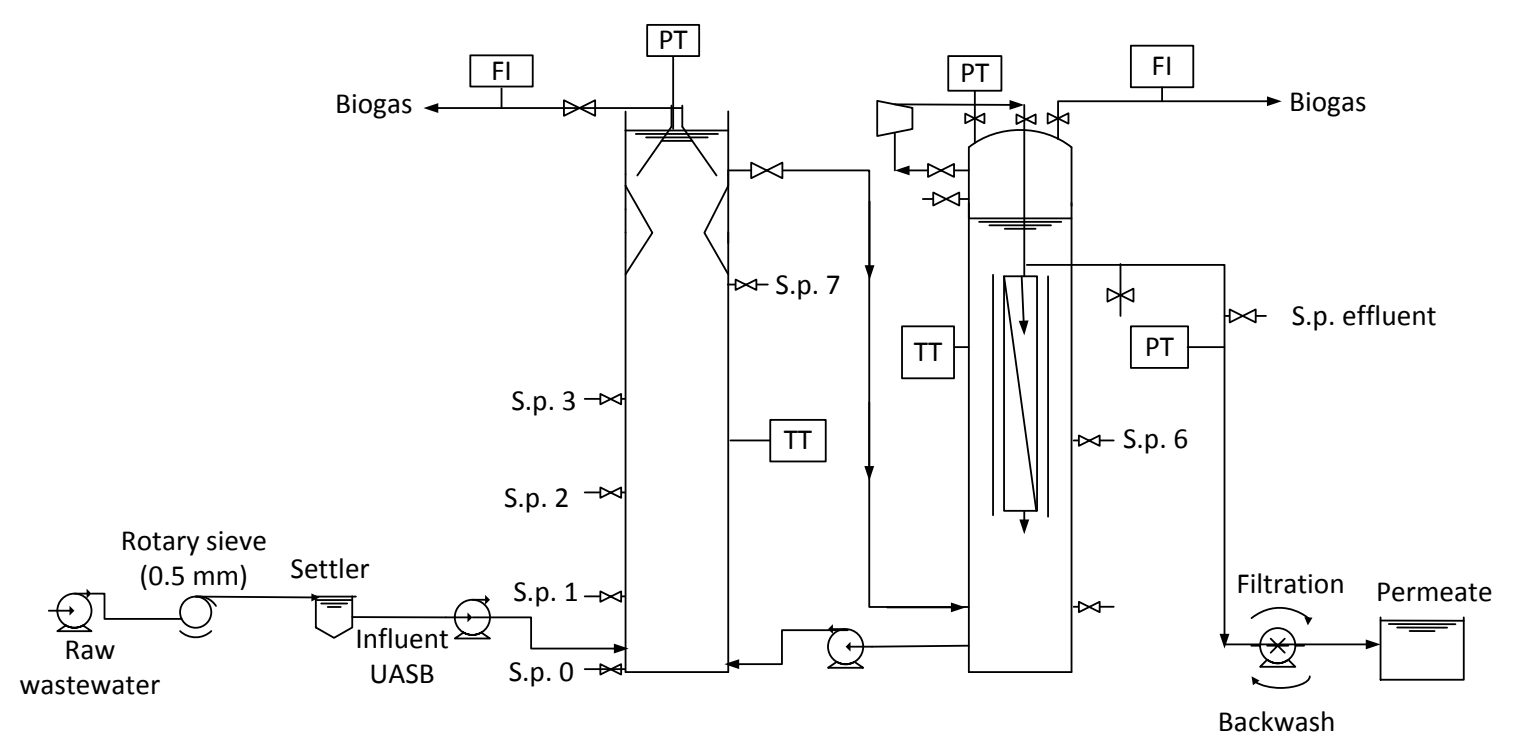

Figure 3.3. AnMBR pilot plant flow scheme (FI- Flow-rate Indicate; PT- Pressure Transmit; TT- Temperature Transmit; S.p.- sampling point). 


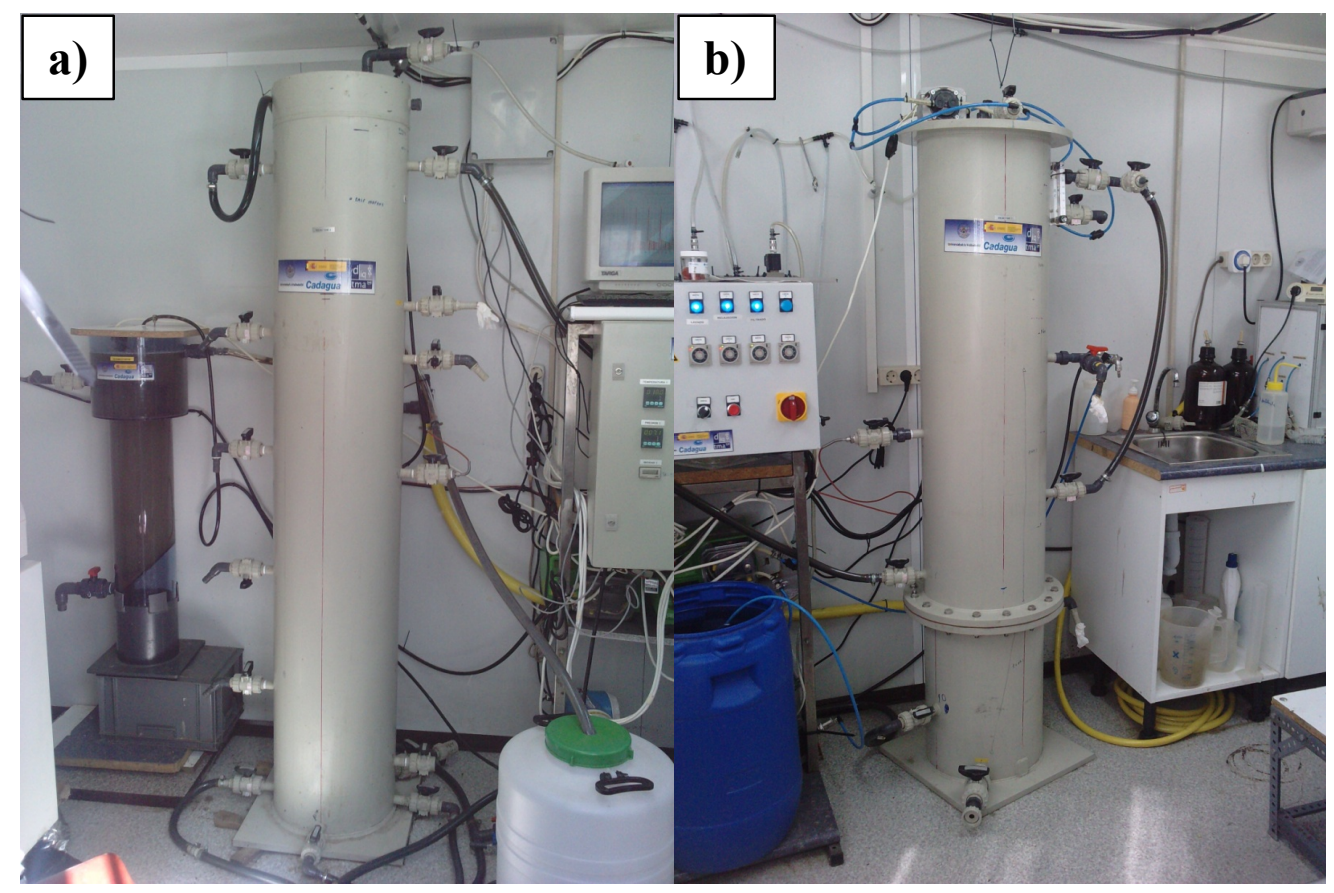

Figure 3.4. AnMBR pilot plant: a) UASB reactor, b) external membrane tank.

\subsubsection{Equipments, instrumentation and operational mode}

Raw sewage was pumped from the municipal sewer to a rotary sieve (Fig. 3.1), pretreated in a circular primary settler (Fig. 3.2) and then fed to the bottom of the UASB reactor with a WATSON MARLOW pump (model WM520S).

In the upper part of the UASB reactor and the membrane tank, the gas pressure of the headspace was measured by two Endress Hauser pressure transmitters (type PMC: 131 (0 to $10 \mathrm{KPa})$ ).

The biogas production was measured by two biogas meter wich measures the amount of biogas generated in the UASB reactor and membrane tank. The fundamental elements that form this biogas meter are: an electrovalve and bobbin (model D399CVC, model 7700), a cylinder with water where conductive rods are submerged with a known volume between the rods of maximum and minimum level; a counter pulse that counts the number of times that the volume is displaced $\left(\mathrm{V}_{\mathrm{UASB}}=148.3 \mathrm{~mL}, \mathrm{~V}_{\operatorname{tank}}=117.8 \mathrm{~mL}\right)$. It is a positive displacement meter.

The effluent of the UASB reactor was conducted by gravity to the bottom of the membrane tank, equipped with a membrane module Zenon ZW-10 and an airlift to increase the superficial velocity. 
To control membrane fouling and to maintain the trans-membrane pressure (TMP), biogas sparging, relaxation time and filtration/backwash were used.

The biogas was continuously sparged through a coarse bubble diffuser located at the bottom of the hollow fibers with a membrane compressor (model SECOH SV50), with different superficial velocities regulated and controlled by a rotameter (Cole Parmer).

The gas pressure of the head space, the temperature, the transmembrane pressure, in the UASB and membrane tank, were recorded with control regulators (BS2100 regulator with relay output and 4/20 mA analogical, Desin Instruments) (Fig. 3.5 a).

The filtration/backwash used a WATSON MARLOW pump (model WM520U), controlled by four timers (Model H3CR, OMRON) (Fig. 3.5 b) to control the operating time. The standart operation cycle, was divided in two periods. In the first period was fixed at 1 min back-flush, $5 \mathrm{~s}$ of relaxation time, and $30 \mathrm{~min}$ filtration followed by $5 \mathrm{~s}$ of relaxation time. In the second period the cycle was reduced to $15 \mathrm{~s}$ back-flush, $5 \mathrm{~s}$ of relaxation time, $7.5 \mathrm{~min}$ filtration, and $5 \mathrm{~s}$ of relaxation time. To measure the pressure filtration and backwash of the membrane, were used an Endress Hauser pressure transmitters (type PMC: $131(-100$ to $100 \mathrm{KPa})$ ).

Due to the accumulation of biosolids in the membrane tank, a pump WATSON MARLOW (model WM520S) was used to recirculate from the membrane tank to the UASB reactor.

Two temperature sensors (PT-100 sensors, Desin Instruments, $0-100^{\circ} \mathrm{C}$ of 3 wires; $\varnothing=$ $6 \mathrm{~mm}$; long: $300 \mathrm{~mm}$,) were placed in the middle part of the UASB reactor and the membrane tank $(70 \mathrm{~cm}$ from the bottom).

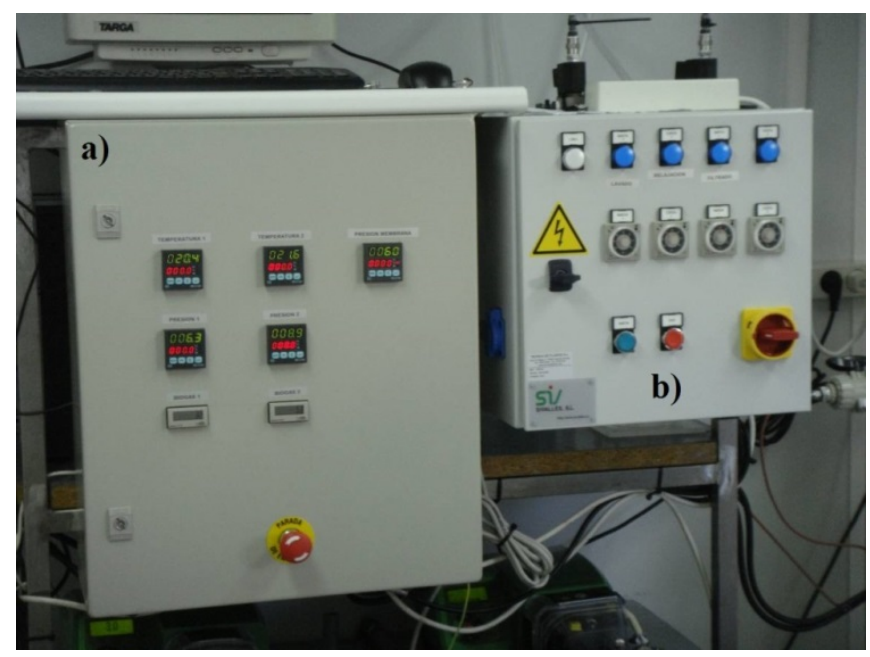

Figure 3.5. Electric panels of the pilot plant: a) BS2100 regulator, b) timers OMRON. 
The data of the headspace of the internal three-phase separator, headspace of the membrane tank, temperature of the UASB reactor and membrane tank, presion of membrane were collected with data acquisition card Picolog Technology Ltd (Fig. 3.6).

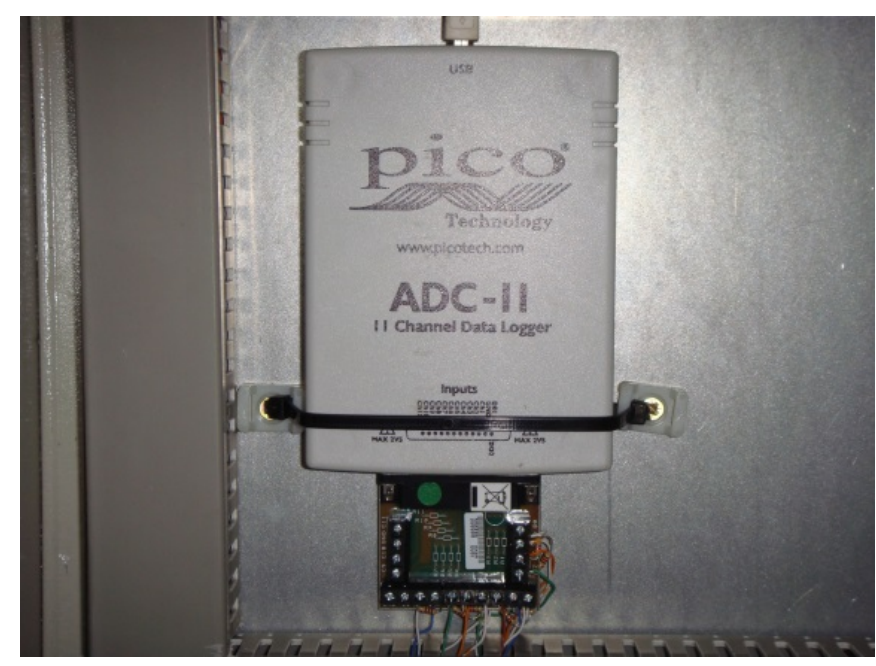

Figure 3.6. Data acquisition card (Picolog Technology Ltd).

\subsubsection{Inoculum of the AnMBR pilot plant}

The UASB reactor was inoculated with $60 \mathrm{~L}$ of sludge from a mesophilic $\left(35^{\circ} \mathrm{C}\right)$ anaerobic sludge pilot digester without previous acclimatization to psychrophilic conditions. The initial concentration of sludge in the UASB was around $10 \mathrm{~g} / \mathrm{L}$ of TSS (total suspended solid). After ten months of operation, the reactor was reinoculated with $43 \mathrm{~L}$ of non-acclimated sludge from a mesophilic digester (flocculent sludge) of the wastewater treatment plant (WWTP) of Valladolid with $51.4 \mathrm{~g} \mathrm{TSS} / \mathrm{L}$. 


\subsubsection{Description of the AnSMBR pilot plant}

Fig. 3.7 and 3.8 shows the the experimental set up and the AnSMBR pilot plant, respectively.

The reactor was built on PPH (Polypropylene Homo-Polymer's). The UASB reactor has a volume of $326.9 \mathrm{~L}$ (height $2360 \mathrm{~mm}$, internal diameter $420 \mathrm{~mm}$ ) using a useful volume of $284 \mathrm{~L}$. In the top of the UASB reactor there is one internal three-phase separator with a hypotenuse of $28 \mathrm{~cm}$ and an inclination of $50^{\circ}$. In the upper part of the UASB reactor, submerged internally is the filtration section built in PPH, a volume of $175 \mathrm{~L}$ (height $1260 \mathrm{~mm}$, internal diameter $420 \mathrm{~mm}$ ) with a useful volume of $165 \mathrm{~L}$.

The filtration section in the upper part has a support to the membranes and a bridle to remove the membranes, in the botton there is two baffles (inclination of $45^{\circ}$ ) between the three-phase separator and the ultrafiltration section in order to improve settling ability.

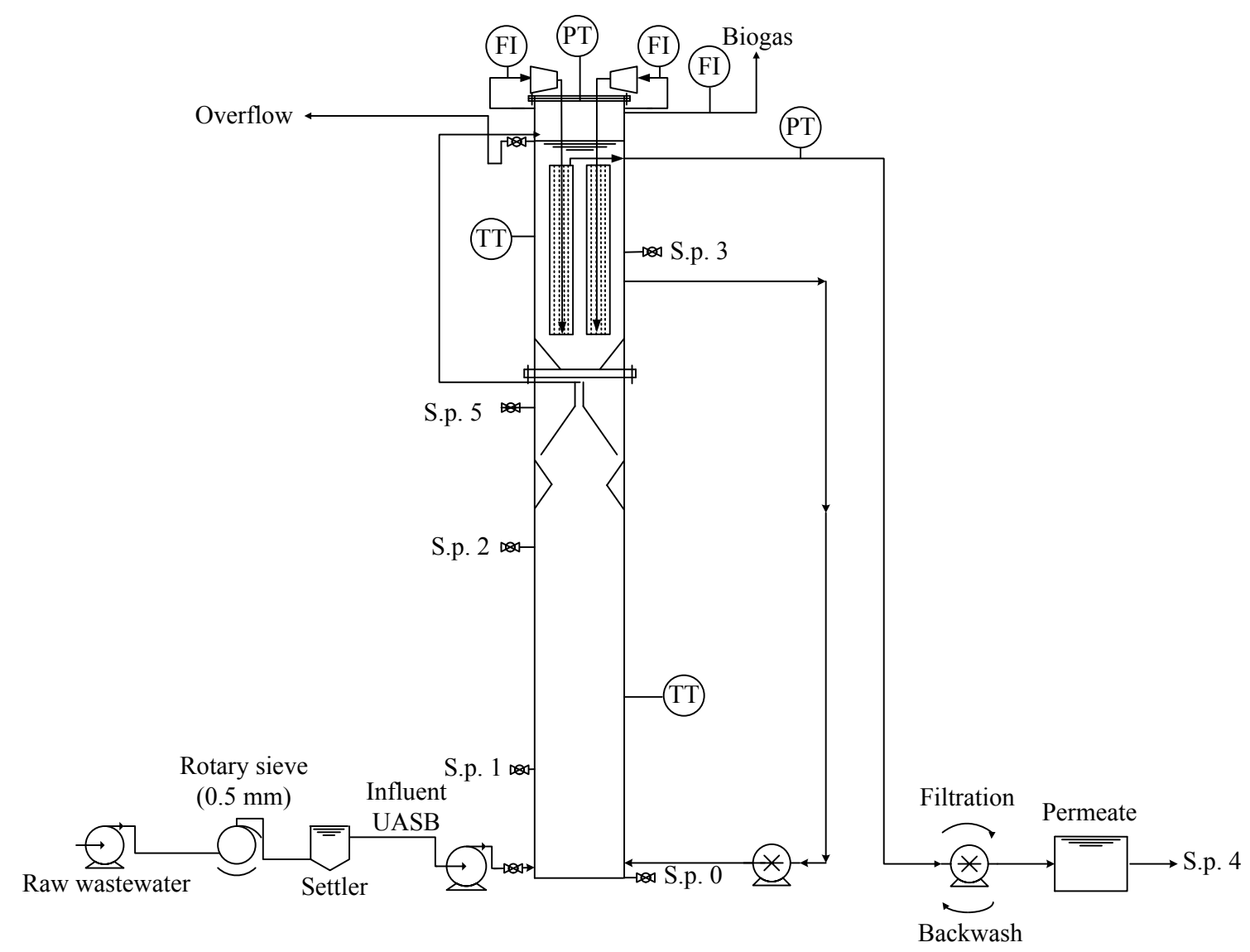

Figure 3.7. AnSMBR pilot plant flow scheme (FI- Flow-rate Indicate; PT -Pressure Transmit; TT- Temperature Transmit; S.p.- sampling point). 


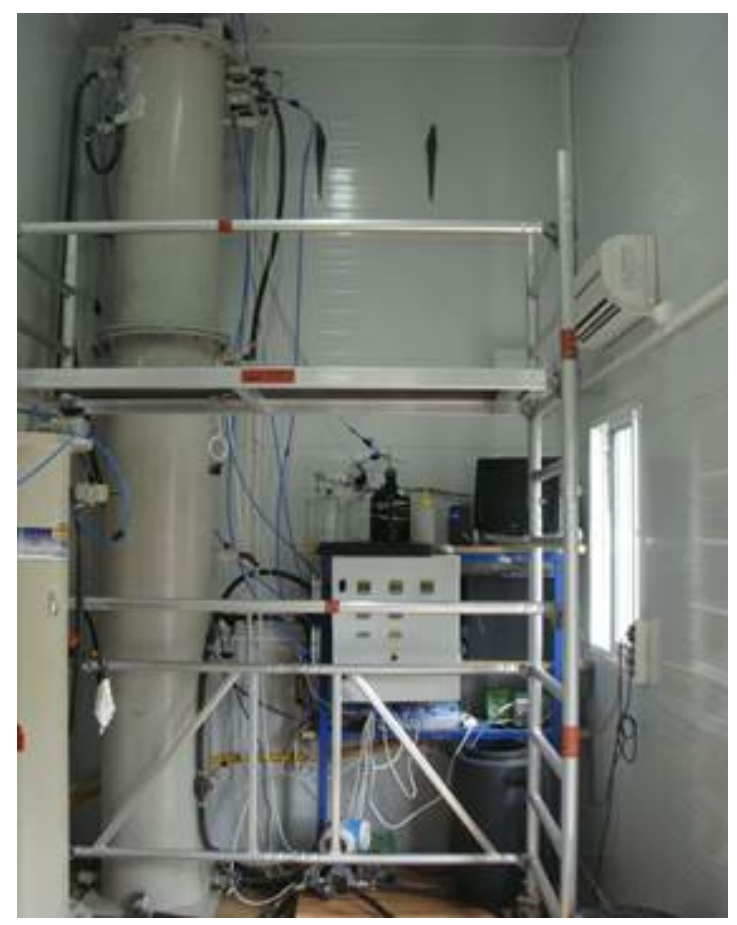

Figure 3.8. AnSMBR pilot plant: UASB reactor with polymeric hollow fiber membrane submerged internally on top.

\subsubsection{Equipments, instrumentation and operational mode}

Raw sewage was pumped from the municipal sewer to a rotary sieve (Fig. 3.1), pretreated in a circular primary settler (Fig. 3.2) and then fed to the bottom of the UASB reactor with a WATSON MARLOW pump (model WM520S).

In the upper part of the filtration section, the gas pressure of the headspace was measured by one Endress Hauser pressure transmitters (type PMC: 131 (0 to $10 \mathrm{KPa})$ ). The biogas production was measured by a biogas meter wich measures the amount of biogas generated in the headspace of the filtracion section. The fundamental elements that form this biogas meter are: an electrovalve and bobbin (model D399CVC, model 7700), a cylinder with water where conductive rods are submerged with a known volume between the rods of maximum and minimum level; a counter pulse that counts the number of times that the volume is displaced $(465 \mathrm{~mL})$. It is a positive displacement meter.

To control membrane fouling and to maintain the trans-membrane pressure (TMP), biogas sparging, relaxation time and filtration/backwash were used. 
The biogas was continuously sparged through a coarse bubble diffuser located at the bottom of the hollow fibers with two membrane compressor (model SECOH SV50), with different superficial velocities regulated and controlled by two rotameter (Cole Parmer).

The gas pressure in the headspace, the temperature, the transmembrane pressure, in the UASB and membrane tank, were recorded with control regulators (BS2100 regulator with relay output and 4/20 mA analogical, Desin Instruments) (similar to Fig. 3.5 a).

The filtration/backwash used a pump WATSON MARLOW (model WM520U), controlled by four timers (Model H3CR, OMRON) (similar to Fig. 3.5 b) to control the operating time. The initial operation cycle was fixed at $15 \mathrm{~min}$ filtration, $10 \mathrm{~s}$ relaxation time, 1 min back-flush and a further $10 \mathrm{~s}$ relaxation time, decreasing after a time to 7.5 min filtration, and the back-flush to $0.5 \mathrm{~min}$. To measure the pressure filtration and backwash of the membrane, has been used an Endress Hauser pressure transmitters (type PMC: 131 (-100 to $100 \mathrm{KPa})$ ).

In order to facilitate the circulation of solids between the filtration section and the biological section, and to try to reduce the fouling of the membrane a WATSON MARLOW pump (model WM520S) was used. The recirculation has been done from the middle of the filtration section to the bottom of the biological section.

Two temperature sensors (PT-100 sensors, Desin Instruments, $0-100^{\circ} \mathrm{C}$ of 3 wires; $\varnothing=$ $6 \mathrm{~mm}$; long: $300 \mathrm{~mm}$, cable 3 meters with reinforced dock) was placed at the bottom of the UASB reactor ( $1 \mathrm{~m}$ from the bottom), and the other one was placed on top, in the filtration section ( $1 \mathrm{~m}$ from the top).

The data of the headspace pressure of the filtration seccion, temperature of the UASB reactor and filtration seccion, presion of membrane were collected with data acquisition card Picolog Technology Ltd (similar to Fig. 3.6).

\subsubsection{Inoculum of the AnSMBR pilot plant}

The reactor was inoculated with $85 \mathrm{~L}$ of granular sludge (6.6 $\mathrm{kg}$ of volatile solid) from a mesophilic anaerobic reactor treating wastewater from a paper recycling factory without any previous acclimatization to psychrophilic conditions. After 10 months of operation, the reactor was reinoculated with $115 \mathrm{~L}$ of granular sludge $(7.5 \mathrm{~kg}$ VS) from the same mesophilic anaerobic reactor also without acclimation. 


\subsection{General characteristics of the membrane module}

It was used a polymeric hollow fiber membrane (fig. 3.9) (one for the AnMBR and two for the AnSMBR). The characteristics of the polymeric hollow fiber were described in table 3.1.

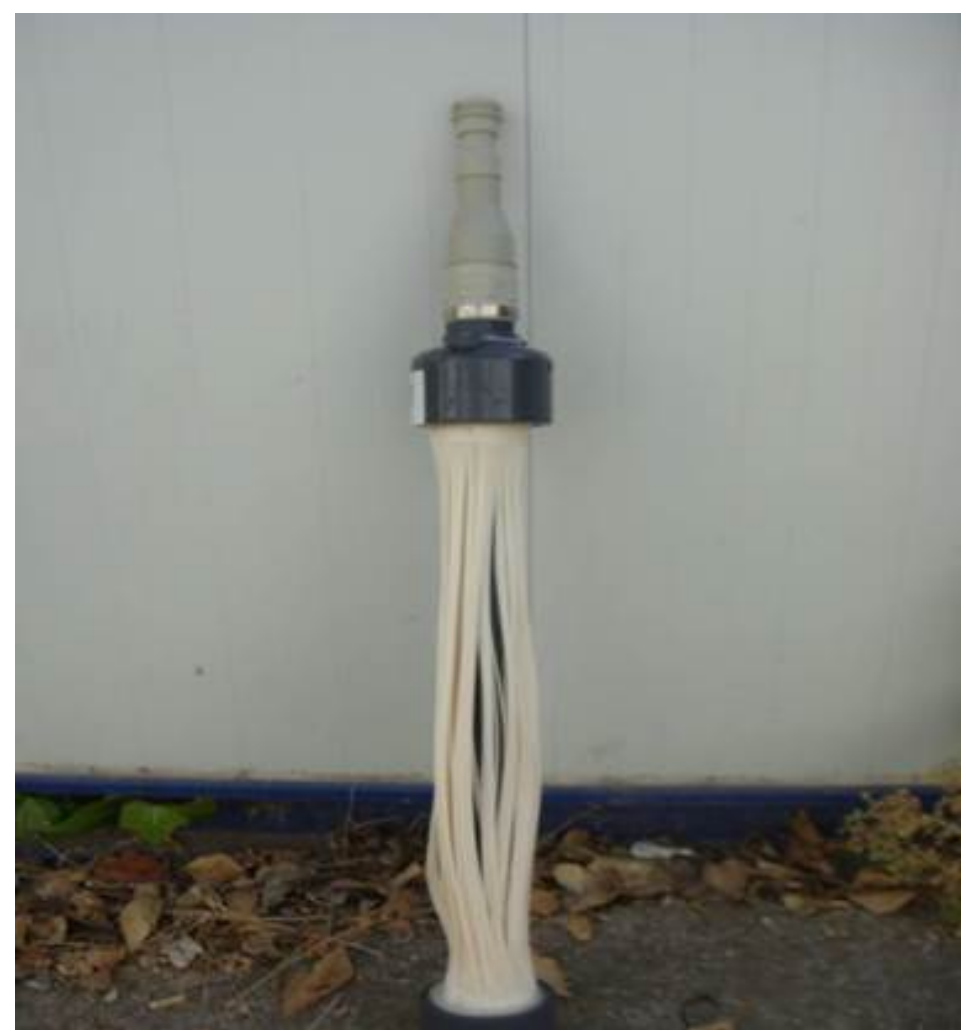

Figure 3.9. Membrane module scheme (Zenon ZW-10). 
Table 3.1. Characteristics of the membrane module Zenon ZW-10 used in both pilot plants.

\begin{tabular}{ccc}
\hline Type of membrane & \multicolumn{2}{c}{ Zenon ZeeWeed $^{(B)} \mathrm{ZW}-10$} \\
Nominal membrane area & 0.93 & $\mathrm{~m}^{2}$ \\
Module weight (dry) & 1.9 & $\mathrm{Kg}$ \\
Module weight (wet) & 2.1 & $\mathrm{Kg}$ \\
Nominal pore size & 0.04 & $\mu \mathrm{m}$ \\
Maximum transmembrane pressure & $62^{(1)}$ & $\mathrm{KPa}$ \\
Typical production permeate & $0.5-0.75^{(2)}$ & $\mathrm{L} / \mathrm{min}$ \\
Typical TMP of operation & $10-50^{(1)}$ & $\mathrm{KPa}$ \\
Maximum working temperature & 40 & ${ }^{\circ} \mathrm{C}$ \\
Operating pH range & $5-9$ & \\
Maximum cleaning temperature & 40 & ${ }^{\circ} \mathrm{C}$ \\
pH cleaning range & $2-10.5$ & $\mathrm{mg} / \mathrm{L}$ \\
Maximum exposure to OCl & 1000 & $\mathrm{KPa}$ \\
Maximum pressure backwash & 55 & $\mathrm{~m}^{3} / \mathrm{h}$ \\
\hline Maximum flow aeration per module & 3.6 & \\
\hline
\end{tabular}

(1) $40^{\circ} \mathrm{C}$; ${ }^{(2)}$ depending on the applications and wastewater to be treated 


\subsubsection{Membrane resistance and permeability of the AnMBR and AnSMBR}

In the figure 3.10 , the characterization of new membrane with tap water at $18 \pm 2^{\circ} \mathrm{C}$, with different fluxes are represented. With this characterization, the membrane resistance $\left(\mathrm{R}_{\mathrm{M}}\right)$ and permeability (Perm) are shown in table 3.2.
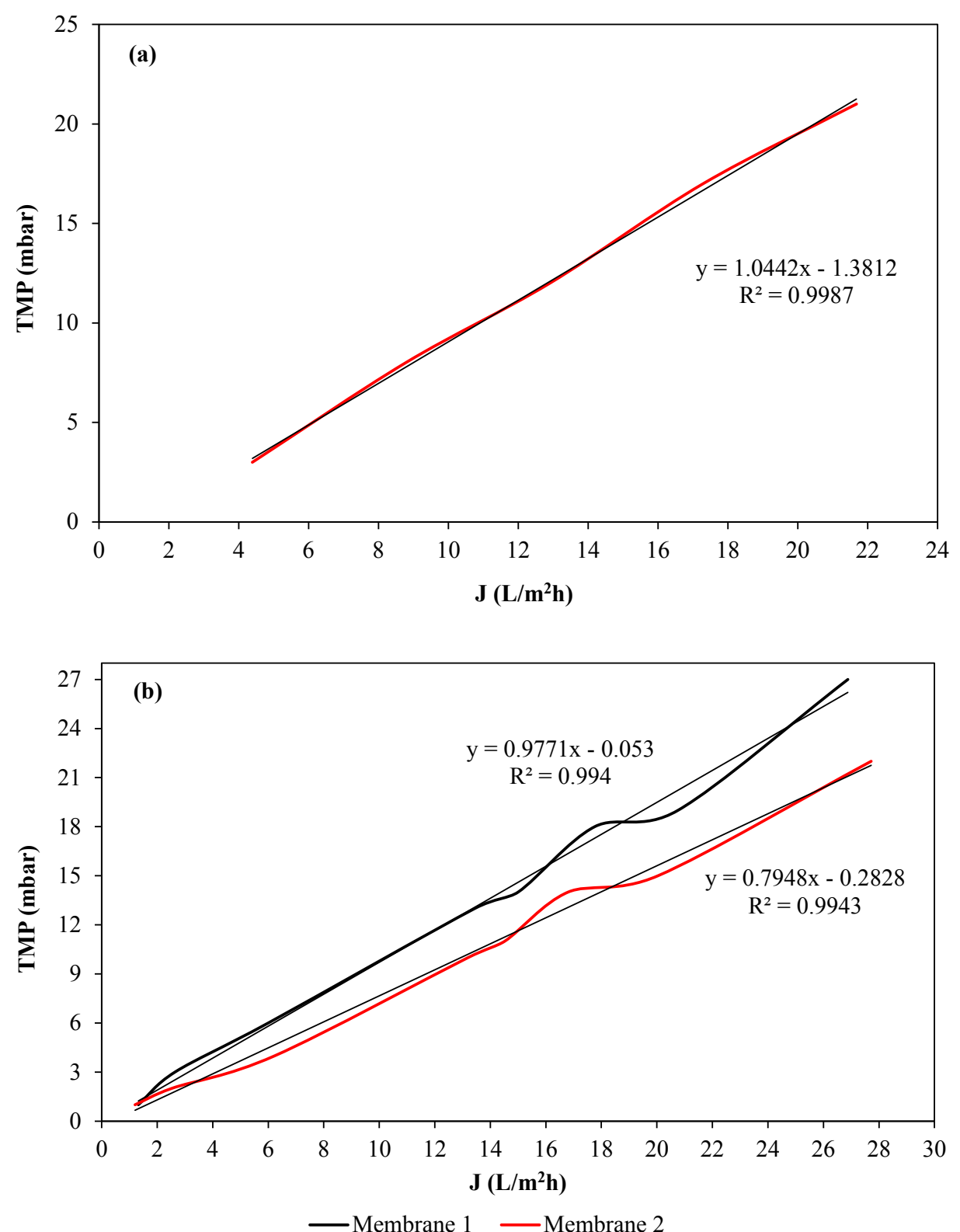

Figure 3.10. Characterization of the new membrane with tap water at $18 \pm 2^{\circ} \mathrm{C}$. (a) AnMBR, (b) AnSMBR. 
Table 3.2. Membrane resistance and permeability of the new membrane for both pilot plants.

\begin{tabular}{ccc}
\hline & $\mathbf{R}_{\mathbf{M}} * \mathbf{1 0}^{13}\left(\mathbf{m}^{-1}\right)$ & Perm $\left(\mathbf{L ~ m}^{-2} \mathbf{h}^{-1} \mathbf{m b a r}^{-1}\right)$ \\
\hline AnMBR & 0.0375 & 0.958 \\
AnSMBR & $0.0352^{*} / 0.0286^{* *}$ & $1.023 * / 1.258^{* *}$
\end{tabular}

*-membrane $1 * *$-membrane 2

\subsection{Membrane cleaning methods}

Membrane cleaning including physical and chemical cleaning was done at $18 \pm 2^{\circ} \mathrm{C}$, to carry out the recovery of the permeability.

\subsubsection{Physical cleaning}

Physical cleaning was carried outside the membrane tank and filtration seccion, with a moderate flow of tap water over the membrane module, in order to decrease the filtration resistance and removing only clogged materials.

\subsubsection{Chemical cleaning}

Chemical cleaning was carried outside the membrane tank and filtration seccion and was performed using acid and oxidants cleaners. The oxidant cleaner used in the cleaning of the two pilots plants was $\mathrm{NaClO}$ with $1000 \mathrm{ppm}$ and a total time between 4-6h. With the aim of intensifying the cleaning, the concentration solution is changed to every two hours to maintain the concentration in solution and was used cycles of filtration and backwash to extend the contact period of the cleaning solution with the membrane.

The acid cleaners used were citric acid $(1 \mathrm{~g} / \mathrm{L}, 2 \mathrm{~g} / \mathrm{L})$ and $\mathrm{HCl}(1 \mathrm{~g} / \mathrm{L})$ until $\mathrm{pH} 3$, and EDTA $(1 \mathrm{w} \%)$ until $\mathrm{pH} 6$ neutralized with $\mathrm{NaOH}(6 \mathrm{M})$. This cleaning was done to improve the cleaning performed with $\mathrm{NaClO}$. 


\subsection{Chemical Analysis Protocol}

The analyzes were carried out in the different sampling points of the AnMBR (fig. 3.3) and AnSMBR (fig. 3.7), for monitoring twice a week.

Alkalinity, tCOD, sCOD, total solids (TS), volatile solids (VS), TSS, volatile suspended solids (VSS), $\mathrm{BOD}_{5}$, total nitrogen $(\mathrm{N}-\mathrm{TKN})$ and ammonia nitrogen $\left(\mathrm{N}-\mathrm{NH}_{4}{ }^{+}\right)$were determined according to the Standard methods for examination of water and wastewater (APHA., AWWA. and WPCF., 2005). sCOD was determined following sample filtration through $0.45 \mu \mathrm{m}$.

\subsubsection{Volatile fatty acids (VFAs) concentration}

The concentrations of volatile fatty acids were determined by gas chromatography using Agilent 7820A GC-FID equipped with a G4513A autosampler and a Chromosorb WAW packed column $(2 \mathrm{~m} \times 1 / 8$ " $\times 2.1 \mathrm{~mm} \mathrm{SS})\left(10 \%\right.$ SP $1000,1 \% \mathrm{H}_{3} \mathrm{PO}_{4}$, WAW 100/120) (Teknokroma, Spain). The injector, oven and detector temperatures were $375^{\circ} \mathrm{C}, 130^{\circ} \mathrm{C}$ and $350^{\circ} \mathrm{C}$, respectively. $\mathrm{N}_{2}$ was used as the carrier gas at $45 \mathrm{~mL} \mathrm{~min}^{-1}$.

3.6.2. Nitrate nitrogen $\left(\mathrm{NO}_{3}{ }_{3}^{-}-\mathrm{N}\right)$, nitrite nitrogen $\left(\mathrm{NO}_{2}^{-}-\mathrm{N}\right)$, chloride $(\mathrm{Cl})$, sulfate $\left(\mathrm{SO}_{4}{ }^{2-}\right.$ Land soluble phosphorus $\left(P-P O_{4}^{3-}\right)$

Nitrate nitrogen, nitrite nitrogen, chloride, sulfate and soluble phosphorus concentrations were analyzed by HPLC-IC using a Waters 515 HPLC pump (Waters, Milford, USA), coupled with an ion conductivity detector (Waters 432, Milford, USA), and equipped with an IC-Pak Anion Guard-Pak column (Waters, Milford, USA), and an IC-Pak Anion HC (150 mm×4.6 mm) column (Waters, Milford, USA).

\subsubsection{Biogas composition}

Biogas composition was analyzed using a gas chromatograph (Varian CP-3800, Palo Alto, CA, USA) coupled with a thermal conductivity detector and equipped with a $\mathrm{CP}-$ Molsieve 5A $(15 \mathrm{~m} \times 0.53 \mathrm{~mm} \times 15 \mu \mathrm{m})$ and a CP-Pora BOND Q $(25 \mathrm{~m} \times 0.53 \mathrm{~mm} \times 15$ $\mu \mathrm{m})$ columns. The injector, oven and detector temperatures were $150^{\circ} \mathrm{C}, 40{ }^{\circ} \mathrm{C}$ and $175^{\circ} \mathrm{C}$, respectively. Helium was used as the carrier gas at $13.7 \mathrm{~mL} / \mathrm{min}$. 


\subsection{Methanogenic Activity (MA) test}

The methanogenic activity was done with the sludge of different heights of the two pilot plants.

The maximal methanogenic activity is defined as the methane production rate of the sludge under optimal conditions. MA tests were carried out in triplicate, incubated at $18^{\circ} \mathrm{C}$ to simulate actual operational conditions, the substrate/inoculum ratio selected was between $0.03-0.1 \mathrm{~g} \mathrm{COD} / \mathrm{g}$ VS d using $160 \mathrm{~mL}$ serum bottles. The susbtrate is a solution of VFAs (acetic, propionic, butyric acid (4:1:1)). A control test without VFAs was included to determine the production of biogas from the inoculum added. TS and VS were measured to determine the quantity of sludge added in the serum bottles prior to MA test. Each serum bottle contained inoculum, nutrient solution, respectively.

Nutrients and trace elements were added for optimal function of anaerobic microorganisms in the MA test and biochemical methane potential tests. A typical basic medium for batch tests is prepared from the following stock solutions (per liter): $\mathrm{KH}_{2} \mathrm{PO}_{4}, 37 \mathrm{~g} ; \mathrm{NH}_{4} \mathrm{Cl}, 170 \mathrm{~g} ; \mathrm{CaCl}_{2} .2 \mathrm{H}_{2} \mathrm{O}, 8 \mathrm{~g} ; \mathrm{MgCl}_{2} .4 \mathrm{H}_{2} \mathrm{O}, 9 \mathrm{~g}$; trace-metal solution: $\mathrm{H}_{3} \mathrm{BO}_{3}, 0.05 \mathrm{~g} ; \mathrm{FeCl}_{3} \cdot 4 \mathrm{H}_{2} \mathrm{O}, 2 \mathrm{~g} ; \mathrm{MnCl}_{2} \cdot 4 \mathrm{H}_{2} \mathrm{O}, 0.5 \mathrm{~g} ; \mathrm{CuCl}_{2} \cdot 2 \mathrm{H}_{2} \mathrm{O}, 0.03 \mathrm{~g}$; $\left(\mathrm{NH}_{4}\right)_{6} \mathrm{Mo}_{7} \mathrm{O}_{24} .4 \mathrm{H}_{2} \mathrm{O}, 0.09 \mathrm{~g} ; \mathrm{CoCl}_{2} \cdot 6 \mathrm{H}_{2} \mathrm{O}, 2 \mathrm{~g} ; \mathrm{NiCl}_{2} \cdot 6 \mathrm{H}_{2} \mathrm{O}, 0.05 \mathrm{~g} ; \mathrm{Na}_{2} \mathrm{SeO}_{3} .5 \mathrm{H}_{2} \mathrm{O}, 0.1$ g; EDTA, 1 g; resazurine, $0.5 \mathrm{~g}$; $\mathrm{ZnCl}_{2}, 0.05 \mathrm{~g}$; $0.1 \% \mathrm{HCl}$.

After adjusting $\mathrm{pH}$ to 7 by $\mathrm{NaOH}$, the final volume was adjusted to $80 \mathrm{ml}$ using distilled water. Oxygen in the liquid was purged by He for $5 \mathrm{~min}$. The serum bottles (fig. 3.11) were sealed with butyl rubber stoppers.

Biogas production was estimated by measuring the pressure in the headspace of the bottles using a pressure transmitter (IFM, 5 mbar precision) and the biogas composition using a gas chromatograph (Varian CP-3800, Palo Alto, CA, USA).

\subsection{Biochemical Methane Potential (BMP) tests}

BMP tests were carried out in triplicate to assess the biodegradability of the accumulated material in the membrane tank and filtration seccion of the two pilot plants. A control test without substrate was included. All the experiments were carried out under mesophilic conditions in a thermostatic room $\left(35.1 \pm 0.3^{\circ} \mathrm{C}\right)$ and were subjected to continuous agitation in an orbital shaker. The anaerobic inoculum used was obtained from a pilot sludge digester and pre-incubated for two days $\left(35.1 \pm 0.3^{\circ} \mathrm{C}\right)$ in 
order to minimize its residual biodegradable organic matter content. Serum bottles of $120 \mathrm{~mL}$ volume (Figure 3.11) were used in the BMP tests, with a reaction volume of $60 \mathrm{~mL}$ in order to have enough headspace for biogas accumulation. The substrate/inoculum ratio selected was $0.4 \mathrm{~g} \mathrm{VS} / \mathrm{g} \mathrm{VS}$. The $\mathrm{pH}$ of the substrate/inoculum mixture was measured to ensure optimum biological activity and the bottles were gassed with He and sealed immediately using rubber septa and aluminum crimp caps. Biogas production was estimated by measuring the pressure in the headspace of the bottles and the biogas composition. The specific methane yield (SMY), $\mathrm{mL} \mathrm{CH}_{4} / \mathrm{g} \mathrm{VS}_{\mathrm{fed}}$ was calculated by dividing the methane production associated with the substrate (after having subtracted the production due to inoculum) by the quantity of volatile solids of substrate at the beginning of the test. The theoretical methane production was calculated assuming that $350 \mathrm{~L}$ of methane was generated per $\mathrm{kg}$ of COD removed.
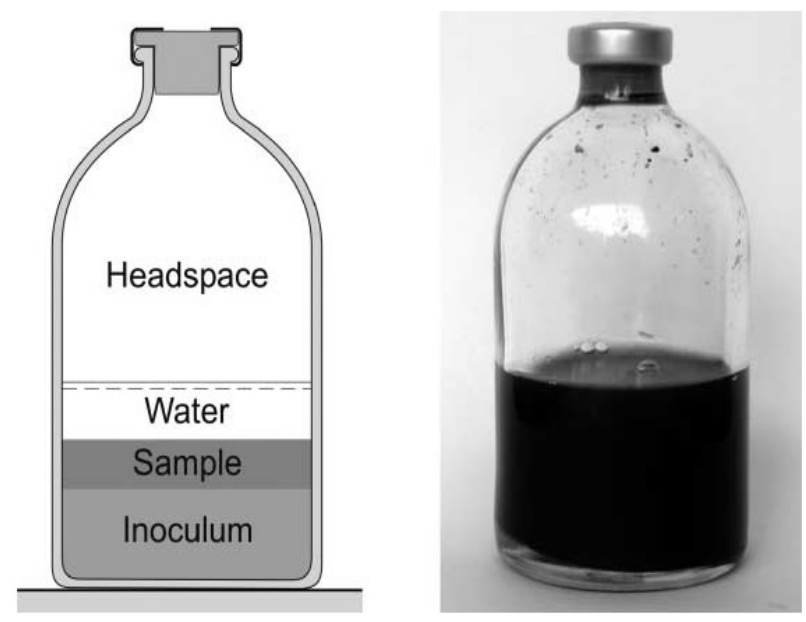

Figure 3.11. Experimental set-up for MA and BMP tests.

\subsection{Jar-test}

Jar-tests to determine the cationic polymer dose were used. Preliminary jar-tests were carried out to assess the effect of the polymer MPE50 ${ }^{\mathrm{TM}}$ with the aim to decrease the concentration of solids in the bulk solution accumulated on the membrane tank.

\subsection{Particle Size Distribution (PSD)}

Particle size distributions of the sludge in the UASB and filtration unit were determined by a Malvern Mastersizer 2000 instrument with a detection range of $0.02-2,000 \mu \mathrm{m}$. The scattered light was detected by means of a detector that converted the signal to a 
size distribution based on volume. Each sample was measured three times with a standard deviation of $0.1-4.5 \%$.

\subsection{Turbidity Metter}

The turbidity (NTU) was measured using a Turbidity Metter Microprocessor HI93703 from Hanna Instruments.

\subsection{Determination of desorbed $\mathrm{CH}_{4}$ in the effluent}

The methodology used for sampling and determination of desorbed methane, was as follows:

(a) $1.5 \mathrm{~L}$ of the effluent was carefully collected in $2.15 \mathrm{~L}$ borosilicate glass bottles avoiding any turbulence. The bottles were immediately closed with rubber stoppers and sealed with aluminum caps kept.

(b) After, the bottle was manually agitated for $3 \mathrm{~min}$ in order to desorb the dissolved methane in the liquid phase.

(c) Then, the headspace of the bottle was sampled and analyzed to determine the gas composition.

(d) The volume of the gas phase was assessed, by the difference between the total volume of the bottle and the volume of the liquid.). The amount of desorbed methane was calculated according to Equation (1).

$\mathrm{PV}=\mathrm{nRT}$

where $\mathrm{P}$, total pressure of the gas phase (atm); V, volume of the gas phase (L); $\mathrm{T}$, temperature of the experiment $(\mathrm{K})$; $\mathrm{R}$, ideal gas constant $\left(\mathrm{L}\right.$ atm $\left.\mathrm{K}^{-1} \mathrm{~mol}^{-1}\right)$, and knowing the volume of liquid, is calculated the $\mathrm{g} \mathrm{CH}_{4 \text { desorbed }} / \mathrm{L}$ in the effluent. 
(e) During 3 to $4 \mathrm{hrs}$ rested to reach equilibrium between the gas phase and liquid phase, the head space of the bottle was sampled and analyzed to determine the gas composition.

(f) When the equilibrium is reached the $\mathrm{CH}_{4}$ dissolved in equilibrium with water (liquid phase), was calculated with the Henry's Law constant at $20^{\circ} \mathrm{C}\left(1.418^{*} 10^{-3}\right.$ $\left.\mathrm{mol} \mathrm{atm} \mathrm{L}^{-1}\right)$.

\subsection{Cell viability}

The sludge for this analyse was taken from the UASB reactor and membrane tank of the both pilot plants.

A LIVE/DEAD® ${ }^{\circledR}$ BacLight $^{\mathrm{TM}}$ bacterial viability kit (L13152, Molecular Probes, Invitrogen Detection Technologies) was used to determine the live/dead ratio. Direct viable and total counts of bacteria were also obtained with Baclight viability kit. Samples were incubated in the dark at room temperature for time periods varying from 5 to $20 \mathrm{~min}$. The two BacLight stains, SYTO 9 and propidium iodide, dissolved in DMSO, were mixed together $(300 \mu \mathrm{L}+300 \mu \mathrm{L})$ and diluted 1:10 in a $\mathrm{NaCl}$ solution $(0.085 \%)$, providing $6 \mathrm{~mL}$ of BacLight stock solution. The stock solution was kept at $20^{\circ} \mathrm{C}$ and protected from light. When needed, a volume of $30 \mathrm{~mL}$ of BacLight was added to $1 \mathrm{~mL}$ of sample. After incubation, the stained sample was filtered through a $0.2 \mu \mathrm{m}$ Nuclepore black polycarbonate filter, and the filter was mounted in BacLight mounting oil, as described in the instructions provided by the manufacturer. Fluorescence microscopy conditions were the same as for AODC and CTC. Viable cells were fluorescent green, while non-viable cells were fluorescent red (Boulos et al., 1999). 


\subsection{References}

APHA., AWWA. and WPCF., 2005. Standard Methods for the Examination of Water and Wastewater., 21st ed. American Public Health Association, Washington DC. USA.

Boulos, L., Prévost, M., Barbeau, B., Coallier, J., Desjardins, R., 1999. LIVE/DEAD ${ }^{\circledR}$ BacLight $^{\mathrm{TM}}$ : Application of a new rapid staining method for direct enumeration of viable and total bacteria in drinking water. J. Microbiol. Methods 37, 77-86. 



\title{
CHAPTER 4
}

\section{Long-term operation of a pilot scale anaerobic membrane bioreactor (AnMBR) for the treatment of municipal wastewater under psychrophilic conditions}

\begin{abstract}
The performance of a pilot scale anaerobic membrane bioreactor (AnMBR), comprising an upflow anaerobic sludge blanket (UASB) reactor coupled to an external ultrafiltration membrane treating municipal wastewater at $18 \pm 2^{\circ} \mathrm{C}$, was evaluated over three years of stable operation. The reactor was inoculated with a mesophilic inoculum without acclimation. The AnMBR supported a tCOD removal efficiency of $87 \pm 1 \%$ at hydraulic retention time (HRT) of $7 \mathrm{~h}$, operating at a volumetric loading rate (VLR) of between 2 and $2.5 \mathrm{~kg} \mathrm{tCOD} / \mathrm{m}^{3} \mathrm{~d}$, reaching effluent tCOD concentrations of 100-120 $\mathrm{mg} / \mathrm{L}$ and $\mathrm{BOD}_{5}$ concentrations of $35-50 \mathrm{mg} \mathrm{O}_{2} / \mathrm{L}$. Specific methane yield varied from 0.18 to $0.23 \mathrm{Nm}^{3} \mathrm{CH}_{4} / \mathrm{kg} \mathrm{COD}_{\text {removed }}$ depending on the recirculation between the membrane module and the UASB reactor. The permeate flow rate, using cycles of 15 seconds backwash, $7.5 \mathrm{~min}$ filtration, and continuous biogas sparging (40-60 m/h), ranged from 10 to $14 \mathrm{~L} / \mathrm{m}^{2} \mathrm{~h}$ with trans-membrane pressure (TMP) values of $400-550$ mbar.
\end{abstract}





\title{
Long-term operation of a pilot scale anaerobic membrane bioreactor (AnMBR) for the treatment of municipal wastewater under psychrophilic conditions
}

\author{
J. Gouveia ${ }^{\text {a }}$, F. Plaza ${ }^{b}$, G. Garralon ${ }^{\text {b }}$, F. Fdz-Polanco ${ }^{a}$, M. Peña ${ }^{a, *}$ \\ ${ }^{a}$ Department of Chemical Engineering and Environmental Technology, School of Industrial Engineering, Dr. Mergelina s/n, 47011, University of Valladolid, Valladolid, Spain \\ ${ }^{\mathrm{b}}$ CADAGUA. Gran via 45, Bilbao, Spain
}

\section{H I G H L I G H T S}

- Viability of AnMBR at psychrophilic conditions for treating municipal wastewater.

- Effluent with high quality (100-120 $\left.\mathrm{mg} \mathrm{O}_{2} / \mathrm{L}\right)$ at HRT of $7 \mathrm{~h}$.

- The membrane permits the biodegradation of slowly biodegradable matter.

- SMY depends on the recirculation between the membrane module and the UASB reactor.

- Long-term reliability and operability of the AnMBR technology.

\section{A R T I C L E I N F O}

Article history:

Received 16 December 2014

Received in revised form 26 February 2015

Accepted 1 March 2015

Available online 6 March 2015

\section{Keywords:}

Anaerobic membrane bioreactor

Biomass retention

Psychrophilic temperature

Municipal wastewater

Specific methane yield

\begin{abstract}
A B S T R A C T
The performance of a pilot scale anaerobic membrane bioreactor (AnMBR), comprising an upflow anaerobic sludge blanket (UASB) reactor coupled to an external ultrafiltration membrane treating municipal wastewater at $18 \pm 2{ }^{\circ} \mathrm{C}$, was evaluated over three years of stable operation. The reactor was inoculated with a mesophilic inoculum without acclimation. The AnMBR supported a tCOD removal efficiency of $87 \pm 1 \%$ at hydraulic retention time (HRT) of $7 \mathrm{~h}$, operating at a volumetric loading rate (VLR) of between 2 and $2.5 \mathrm{~kg} \mathrm{tCOD} / \mathrm{m}^{3} \mathrm{~d}$, reaching effluent tCOD concentrations of $100-120 \mathrm{mg} / \mathrm{L}$ and $\mathrm{BOD}_{5}$ concentrations of $35-50 \mathrm{mg} \mathrm{O}_{2} / \mathrm{L}$. Specific methane yield varied from 0.18 to $0.23 \mathrm{Nm}^{3} \mathrm{CH}_{4} / \mathrm{kg} \mathrm{COD}_{\text {removed }}$ depending on the recirculation between the membrane module and the UASB reactor. The permeate flow rate, using cycles of $15 \mathrm{~s}$ backwash, $7.5 \mathrm{~min}$ filtration, and continuous biogas sparging $(40-60 \mathrm{~m} / \mathrm{h})$, ranged from 10 to $14 \mathrm{Lm}^{2} / \mathrm{h}$ with trans-membrane pressure (TMP) values of $400-550$ mbar.
\end{abstract}

(c) 2015 Elsevier Ltd. All rights reserved.

\section{Introduction}

Municipal wastewater is the most common type of wastewater, characterized by low organic strength and high particulate organic matter content (Ozgun et al., 2013a). The activated sludge process is the most widely used to treat this wastewater (Rittmann and McCarty, 2001; Metcalf and Eddy, 2003). However, this treatment presents some clear disadvantages when compared to anaerobic treatment, such as its high cost of aeration and the generation of large amounts of residual sludge. Thus, the main conceptual limitation of the activated sludge process is the high biomass yield that implies the use of energy $\left(\mathrm{O}_{2}\right)$ to transform biodegradable

\footnotetext{
* Corresponding author.

E-mail addresses: jgouveia@iq.uva.es (J. Gouveia), ggl@cadagua.es (G. Garralon), ffp@iq.uva.es (F. Fdz-Polanco), pena@iq.uva.es (M. Peña).
}

dissolved or suspended organic matter into settleable microorganisms that are often partially converted into biogas using anaerobic digestion.

In contrast, anaerobic processes, which are widely used for industrial wastewater treatment, have clear advantages such as a significantly lower generation of excess sludge and the conversion of organic matter into valuable biogas without energy consumption (Baek and Pagilla, 2006; Lin et al., 2013; Smith et al., 2012; van Lier et al., 2001). Therefore, the anaerobic process could be an attractive treatment for municipal wastewater in order to reduce sludge production and to optimize energy use. Nevertheless, the advantages of anaerobic treatment are not clear in the case of municipal wastewater, especially in cold weather (Baek and Pagilla, 2006; van Lier et al., 2001). Anaerobic processes strongly depend on operational temperature and therefore the heating of the large volume of municipal wastewater makes 



\subsection{Introduction}

Municipal wastewater is the most common type of wastewater, characterized by low organic strength and high particulate organic matter content (Ozgun et al., 2013a). The activated sludge process is the most widely used to treat this wastewater (Rittmann and McCarty, 2001; Metcalf and Eddy, 2003). However, this treatment presents some clear disadvantages when compared to anaerobic treatment, such as its high cost of aeration and the generation of large amounts of residual sludge. Thus, the main conceptual limitation of the activated sludge process is the high biomass yield that implies the use of energy $\left(\mathrm{O}_{2}\right)$ to transform biodegradable dissolved or suspended organic matter into settleable microorganisms that are often partially converted into biogas using anaerobic digestion.

In contrast, anaerobic processes, which are widely used for industrial wastewater treatment, have clear advantages such as a significantly lower generation of excess sludge and the conversion of organic matter into valuable biogas without energy consumption (Baek and Pagilla, 2006; Lin et al., 2013; Smith et al., 2012; van Lier et al., 2001). Therefore, the anaerobic process could be an attractive treatment for municipal wastewater in order to reduce sludge production and to optimize energy use. Nevertheless, the advantages of anaerobic treatment are not clear in the case of municipal wastewater, especially in cold weather (Baek and Pagilla, 2006; van Lier et al., 2001). Anaerobic processes strongly depend on operational temperature and therefore the heating of the large volume of municipal wastewater makes mesophilic anaerobic treatment economically unviable in cold or temperate countries. There are numerous examples of Upflow Anaerobic Sludge Blanket (UASB) reactor treating municipal wastewater in tropical countries, and the results obtained showed the feasibility of this system at an ambient temperature of around $20-35^{\circ} \mathrm{C}$ (Chernicharo and Machado, 1998; Wiegant, 2001). The low strength of municipal wastewater, together with the slow growth rate of methanogens at temperatures of below $20^{\circ} \mathrm{C}$, would entail high reactor volume as a result of the high residence times to avoid cell washout (Baek and Pagilla, 2006; Lin et al., 2013; Smith et al., 2012; van Lier et al., 2001). In addition, the hydrolysis of particulate matter into dissolved molecules becomes the rate-limiting step, which results in the accumulation of suspended solids (SS) in the reactor, and a decrease in both organic matter conversion efficiency and methanogenic activity (Lettinga et al., 2001; Martinez-Sosa et al., 2011). Conventional 
anaerobic technologies such as UASB and the expended granule sludge blanket (EGSB), based on biofilms or granules with good settling characteristics are adequate for retaining the biomass inside the reactor during the treatment of high strength wastewater under mesophilic conditions. However, when operating at temperatures in the psychrophilic range, these technologies are not sufficient to maintain the high concentration of active biomass, which is the compulsory condition required for the treatment of low strength wastewaters. In this context, the success of the anaerobic technology for municipal wastewater at low temperature depends on the complete separation of HRT and solid retention time (SRT) (Ho and Sung, 2010). The use of micro or ultrafiltration membranes allows the biomass to be completely retained, irrespective of their settling characteristics. Hence, membrane technology combined with anaerobic biological processes, known as the anaerobic membrane bioreactor (AnMBR), seems in theory to offer very attractive possibilities for the treatment of municipal wastewater at psychrophilic temperature (Ozgun et al., 2013a; Smith et al., 2013). Nevertheless, there are still critical technical-economic limitations that hinder the widespread implementation of AnMBRs, such as low operational fluxes, rapid membrane fouling and their high capital and operational costs (Kocadagistan and Topcu, 2007; Ozgun et al., 2013a). Fortunately, membrane acquisition and/or replacement costs have decreased significantly over the past decade due to a decline in membrane module costs (Santos et al., 2011). However, despite the aforementioned constraints, AnMBR has been identified as a key technology for the treatment of municipal wastewater, whose treatment performance is seemingly dependent on the chosen process configuration (Liao et al., 2006). To date, completely stirred tank anaerobic reactors (CSTR), UASB reactors and EGSB reactors have been investigated in combination with micro and ultrafiltration membranes. However, the optimal process configuration, i.e. anaerobic bioreactor type and the coupling of the bioreactor with the membrane module, needs to be determined. In this context, despite several studies having been conducted to date on municipal sewage treatment in anaerobic membrane reactors, the number of long-term studies carried out under psychrophilic conditions on a pilot scale is scarce (Lin et al., 2013; Ozgun et al. 2013; Shin et al., 2014).

The aim of this work was to experimentally assess the long term feasibility of the treatment of municipal wastewater under psychrophilic conditions $\left(18 \pm 2^{\circ} \mathrm{C}\right)$ in a pilot scale AnMBR consisting of an UASB reactor coupled with an ultrafiltration membrane unit. The operability of the membrane, the influence of the HRT, the volumetric loading 
rate (VLR), the effect of the membrane on the treatment of municipal wastewater and the recirculation rate between UASB and the membrane module on the effluent quality was investigated.

\subsection{Materials and methods \\ 4.2.1. Pilot plant configuration}

Fig. 4.1 shows the experimental pilot plant set up. The pilot plant consisted of a rotatory sieve (defender TR-40/25 Toro Wastewater Equipment Industries), a circular primary settler (with a total volume of $25 \mathrm{~L}$ and HRT between 1 and $3 \mathrm{~h}$ ) followed by a UASB reactor coupled to an external submerged membrane module. The volume of the UASB was $160 \mathrm{~L}$ and the volume of the membrane unit $150 \mathrm{~L}$. Both modules were equipped with biogas, temperature and pressure meters. Both the UASB reactor and membrane module were operated at $\mathrm{T}=18 \pm 2^{\circ} \mathrm{C}$. The characteristics of the tubular ultrafiltration membrane module (ZW-10 Zenon, GE) were as follows: mean pore size $0.04 \mu \mathrm{m}$ and filtration area $0.93 \mathrm{~m}^{2}$. The settler, the UASB reactor and the membrane module were placed in a room provided with an air-conditioning system, in order to maintain the temperature of the UASB reactor at $18^{\circ} \mathrm{C}$ during both winter and summer time.

To control membrane fouling and to maintain the trans-membrane pressure (TMP), biogas sparging, relaxation time and permeate back-flush were used. In the first period (day 1-328), the standard operation cycle was fixed at 1 minute back-flush, 5 seconds of relaxation time, and 30 minutes filtration followed by 5 seconds of relaxation time. During the second period (day 329-1371), the cycle was reduced to 15 seconds backflush, 5 seconds of relaxation time, 7.5 minutes filtration, and 5 seconds of relaxation time. The biogas was continuously sparged through a coarse bubble diffuser located at the bottom of the hollow fibers, with a superficial velocity of $25 \mathrm{~m} / \mathrm{h}$ in period I and of $40-60 \mathrm{~m} / \mathrm{h}$ during period II. Temperature and pressure filtration were stored online using data acquisition technology.

The effluent of the UASB reactor was conducted by gravity to the bottom of the membrane module. The system was operated with different recirculation flow rates from the membrane module to the UASB reactor (day 1-1014) in order to ensure good contact between the biomass and the wastewater, to control the concentration of solids in the effluent of the UASB and to minimize solid concentration in the membrane module. The superficial velocity in the UASB was maintained between 0.15 and 0.45 
m/h. From day 1015-1371, the AnMBR was operated without recirculation from the membrane module to the UASB reactor and the superficial velocity in the UASB was maintained at $0.2-0.3 \mathrm{~m} / \mathrm{h}$.

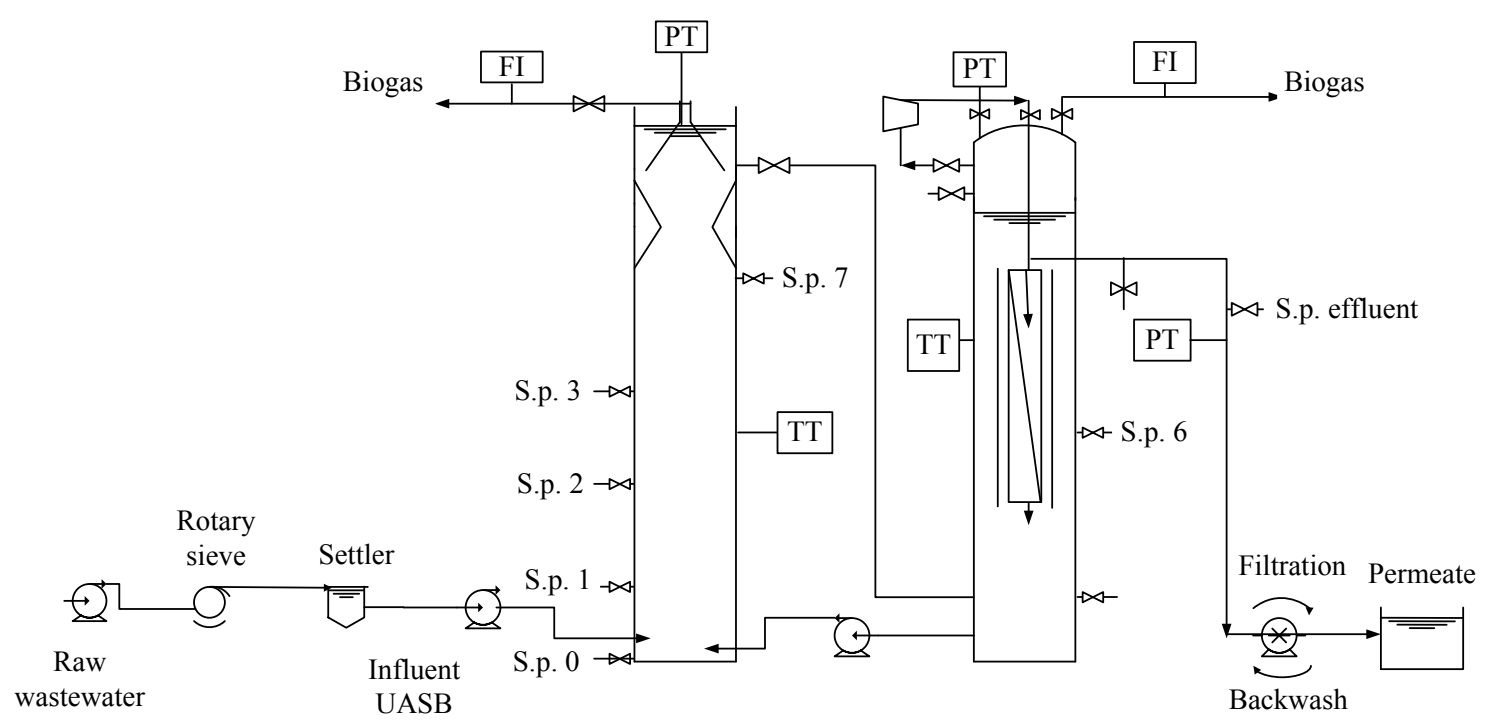

Figure 4.1. AnMBR pilot plant flow scheme (FI- Flow-rate Indicate; PT- Pressure Transmit; TT- Temperature Transmit; S.p.- Sampling point).

\subsubsection{Inoculum and feed wastewater}

The UASB reactor was inoculated with $60 \mathrm{~L}$ of sludge from a mesophilic $\left(35^{\circ} \mathrm{C}\right)$ anaerobic sludge pilot digester without previous acclimatization to psychrophilic conditions. The initial concentration of sludge in the UASB was around $10 \mathrm{~g} / \mathrm{L}$ of TSS (total suspended solid). After ten months of operation, the reactor was reinoculated with $43 \mathrm{~L}$ of non-acclimated sludge from a mesophilic digester (flocculent sludge) of the wastewater treatment plant (WWTP) of Valladolid with $51.4 \mathrm{~g}$ TSS/L. The pilot plant was continuously fed with the raw municipal wastewater from the city of Valladolid drawn from a nearby sewer.

\subsubsection{Chemical assays and sampling}

Liquid samples were taken twice a week from each of the elements of the plant to monitor the process performance, sampling points (S.p.) 0, 1, 2, 3, 7, 6 and effluent, as shown in figure 4.1. Alkalinity, tCOD, sCOD, total solids (TS), volatile solids (VS), total suspended solids (TSS), volatile suspended solids (VSS), biological oxygen 
demand $\left(\mathrm{BOD}_{5}\right)$, total nitrogen $(\mathrm{N}-\mathrm{TKN})$ and ammonia nitrogen $\left(\mathrm{N}-\mathrm{NH}_{4}{ }^{+}\right)$were determined according to the Standard methods for examination of water and wastewater (APHA., AWWA. and WPCF., 2005). sCOD was determined following sample filtration through $0.45 \mu \mathrm{m}$. The concentrations of volatile fatty acids (VFAs) were determined by gas chromatography using Agilent 7820A GC-FID equipped with a G4513A autosampler and a Chromosorb WAW packed column $(2 \mathrm{~m} \times 1 / 8$ " $\times 2.1 \mathrm{~mm}$ SS) $\left(10 \% \mathrm{SP} 1000,1 \% \mathrm{H}_{3} \mathrm{PO}_{4}\right.$, WAW 100/120) (Teknokroma, Spain). The injector, oven and detector temperatures were $375^{\circ} \mathrm{C}, 130^{\circ} \mathrm{C}$ and $350^{\circ} \mathrm{C}$, respectively. $\mathrm{N}_{2}$ was used as the carrier gas at $45 \mathrm{~mL} \mathrm{~min}^{-1}$. Nitrate nitrogen $\left(\mathrm{NO}_{3}{ }^{-} \mathrm{N}\right)$, nitrite nitrogen $\left(\mathrm{NO}_{2}{ }^{-}\right.$ $-\mathrm{N})$, chloride $\left(\mathrm{Cl}^{-}\right)$, sulfate $\left(\mathrm{SO}_{4}{ }^{2-}\right)$ and soluble phosphorus $\left(\mathrm{P}-\mathrm{PO}_{4}{ }^{3-}\right)$ concentrations were analyzed by HPLC-IC using a Waters 515 HPLC pump (Waters, Milford, USA), coupled with an ion conductivity detector (Waters 432, Milford, USA), and equipped with an IC-Pak Anion Guard-Pak column (Waters, Milford, USA), and an IC-Pak Anion HC (150 mm×4.6 mm) column (Waters, Milford, USA). Biogas composition was analyzed using a gas chromatograph (Varian CP-3800, Palo Alto, CA, USA) coupled with a thermal conductivity detector and equipped with a CP-Molsieve $5 \mathrm{~A}(15 \mathrm{~m} \times 0.53$ $\mathrm{mm} \times 15 \mu \mathrm{m})$ and a CP-Pora BOND Q $(25 \mathrm{~m} \times 0.53 \mathrm{~mm} \times 15 \mu \mathrm{m})$ columns. The injector, oven and detector temperatures were $150^{\circ} \mathrm{C}, 40^{\circ} \mathrm{C}$ and $175^{\circ} \mathrm{C}$, respectively. Helium was used as the carrier gas at $13.7 \mathrm{~mL} / \mathrm{min}$.

\subsubsection{Biochemical methane potential assay}

Biochemical methane potential (BMP) tests were carried out in triplicate to assess the biodegradability of the accumulated material in the membrane module. The BMP tests were conducted directly using the suspension from the membrane module, with the concentrated sludge obtained after centrifuging the suspension at 10,000 rpm for 10 min, and the supernatant obtained. A control test without substrate was included. All the experiments were carried out under mesophilic conditions in a thermostatic room $\left(35.1 \pm 0.3^{\circ} \mathrm{C}\right)$ and were subjected to continuous agitation in an orbital shaker. The anaerobic inoculum used was obtained from a pilot sludge digester and pre-incubated for two days $\left(35.1 \pm 0.3^{\circ} \mathrm{C}\right)$ in order to minimize its residual biodegradable organic matter content. Serum bottles of $120 \mathrm{~mL}$ volume were used in the BMP tests, with a reaction volume of $60 \mathrm{~mL}$ in order to have enough headspace for biogas accumulation. The substrate/inoculum ratio selected was $0.4 \mathrm{~g}$ VS/g VS. The $\mathrm{pH}$ of the 
substrate/inoculum mixture was measured to ensure optimum biological activity and the bottles were gassed with He and sealed immediately using rubber septa and aluminum crimp caps. Biogas production was estimated by measuring the pressure in the headspace of the bottles and the biogas composition. The specific methane yield (SMY), $\mathrm{mL} \mathrm{CH}_{4} / \mathrm{g} \mathrm{VS}_{\text {fed }}$ was calculated by dividing the methane production associated with the substrate (after having subtracted the production due to inoculum) by the quantity of volatile solids of substrate at the beginning of the test. The theoretical methane production was calculated assuming that $350 \mathrm{~L}$ of methane was generated per $\mathrm{kg}$ of COD removed.

\subsection{Results and discussion}

The UASB reactor was continuously fed with municipal wastewater after pre-treatment in a rotary sieve $(1 \mathrm{~mm} \mathrm{mesh})$ and primary sedimentation. The main wastewater characteristics fed to the UASB reactor are listed in Table 4.1. There is a significant variation in the tCOD of the municipal wastewater during the entire period of operation. The particulate COD fed to the UASB reactor represented around 30-46\% of the tCOD. Ammonium nitrogen and phosphate concentrations in the influent were $71 \pm 14$ and $10 \pm 2$ $\mathrm{mg} / \mathrm{L}$, respectively. 
Table 4.1. Presettled wastewater characteristics fed to the UASB reactor (average values).

\begin{tabular}{lc}
\hline Parameter & Influent (mg/L) \\
\hline tCOD & $892 \pm 271$ \\
sCOD & $501 \pm 165$ \\
tBOD $_{5}$ & $573 \pm 233$ \\
BBOD $_{5}$ & $335 \pm 31$ \\
$\mathrm{TSS}$ & $123 \pm 35$ \\
$\mathrm{VSS}$ & $110 \pm 30$ \\
$\mathrm{~N}-\mathrm{TKN}^{\mathrm{N}-\mathrm{NH}_{4}{ }^{+}}$ & $92 \pm 12$ \\
$\mathrm{P}_{-} \mathrm{PO}_{4}$ & $71 \pm 14$ \\
$\mathrm{SO}_{4}{ }^{2-}$ & $10 \pm 2$ \\
\hline
\end{tabular}

\subsubsection{Removal efficiency of COD}

The AnMBR was operated by gradually increasing the VLR via a decrease in the HRT of the UASB reactor. Fig. 4.2 shows the removal efficiencies of tCOD, VLR (calculated considering only the volume of the UASB reactor) and tCOD of the influent and effluent of the AnMBR. Table 4.2 summarizes the steady state results obtained for the different HRTs tested. The HRT varied between $17 \mathrm{~h}$ and $11 \mathrm{~h}$ during the period with recirculation and between $13 \mathrm{~h}$ and $7 \mathrm{~h}$ during the period without recirculation. The results showed that, the total removal efficiency was similar regardless of the HRT and VLR tested, probably due to the presence of the membrane. The total removal efficiency obtained was higher than $80 \%$, with tCOD values in the effluent ranging from 110 to $125 \mathrm{mg} \mathrm{O}_{2} / \mathrm{L}$ in both periods. During the period with recirculation, the HRT was decreased to $11 \mathrm{~h}$. Under this operational condition and with a VLR of $2.61 \mathrm{~kg}$ $\mathrm{tCOD} / \mathrm{m}^{3} \mathrm{~d}$, a tCOD removal efficiency of $90.1 \pm 1.2 \%$, an effluent tCOD of $121 \pm 12.9$ mg $\mathrm{O}_{2} / \mathrm{L}$ and an effluent $\mathrm{BOD}_{5}$ of $36 \pm 5.7 \mathrm{mg} \mathrm{O}_{2} / \mathrm{L}$ were obtained. The HRT was decreased to $7 \mathrm{~h}$ when operating without recirculation from the membrane module to the 
UASB reactor, and, even at such a low HRT, good quality effluent was obtained under a VLR of $2.2 \mathrm{~kg} \mathrm{COD} / \mathrm{m}^{3} \mathrm{~d}$; the tCOD of the effluent was $122 \pm 36 \mathrm{mg} \mathrm{O} / 2$. However, when the VLR increased at a constant HRT of $7 \mathrm{~h}$, the tCOD removal efficiency of the AnMBR clearly decreased. During the last period with a HRT of $7 \mathrm{~h}$ and VLRs above 4 $\mathrm{kg} \mathrm{COD} / \mathrm{m}^{3} \mathrm{~d}$, a continuous increase in the tCOD of the effluent was observed, reaching effluent tCOD values of $125-250 \mathrm{mg} \mathrm{O}_{2} / \mathrm{L}$ and effluent $\mathrm{BOD}_{5}$ of $40-125 \mathrm{mg} \mathrm{O} / \mathrm{L}$ at VLRs of $4.5-5.5 \mathrm{~kg} \mathrm{COD} / \mathrm{m}^{3} \mathrm{~d}$ (Fig. 4.2). 


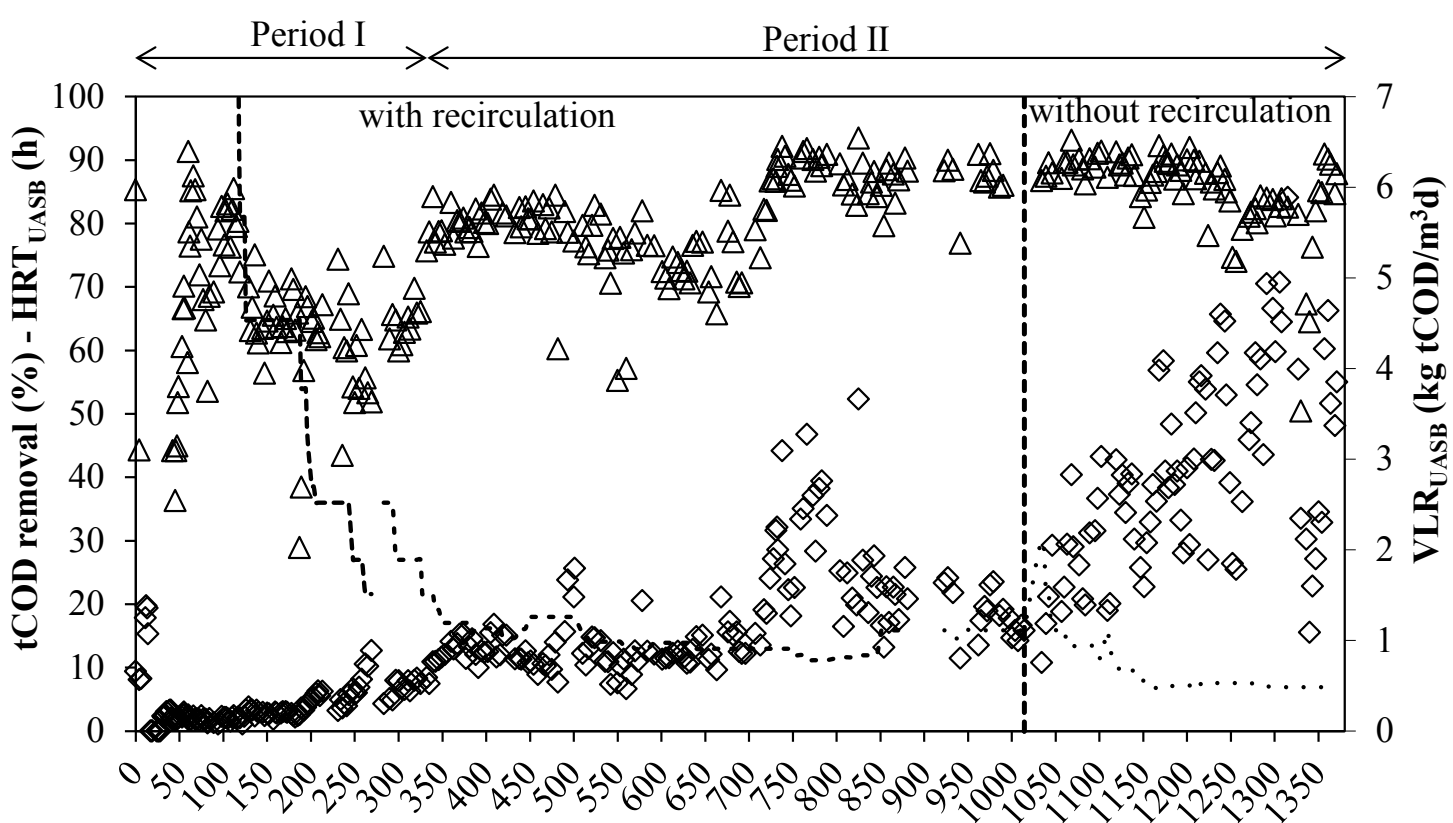

Time (day)

(a)

$$
\lrcorner \text { tCOD removal } \diamond \mathrm{VLR}_{\mathrm{UASB}}---\mathrm{HRT}_{\mathrm{UASB}}
$$

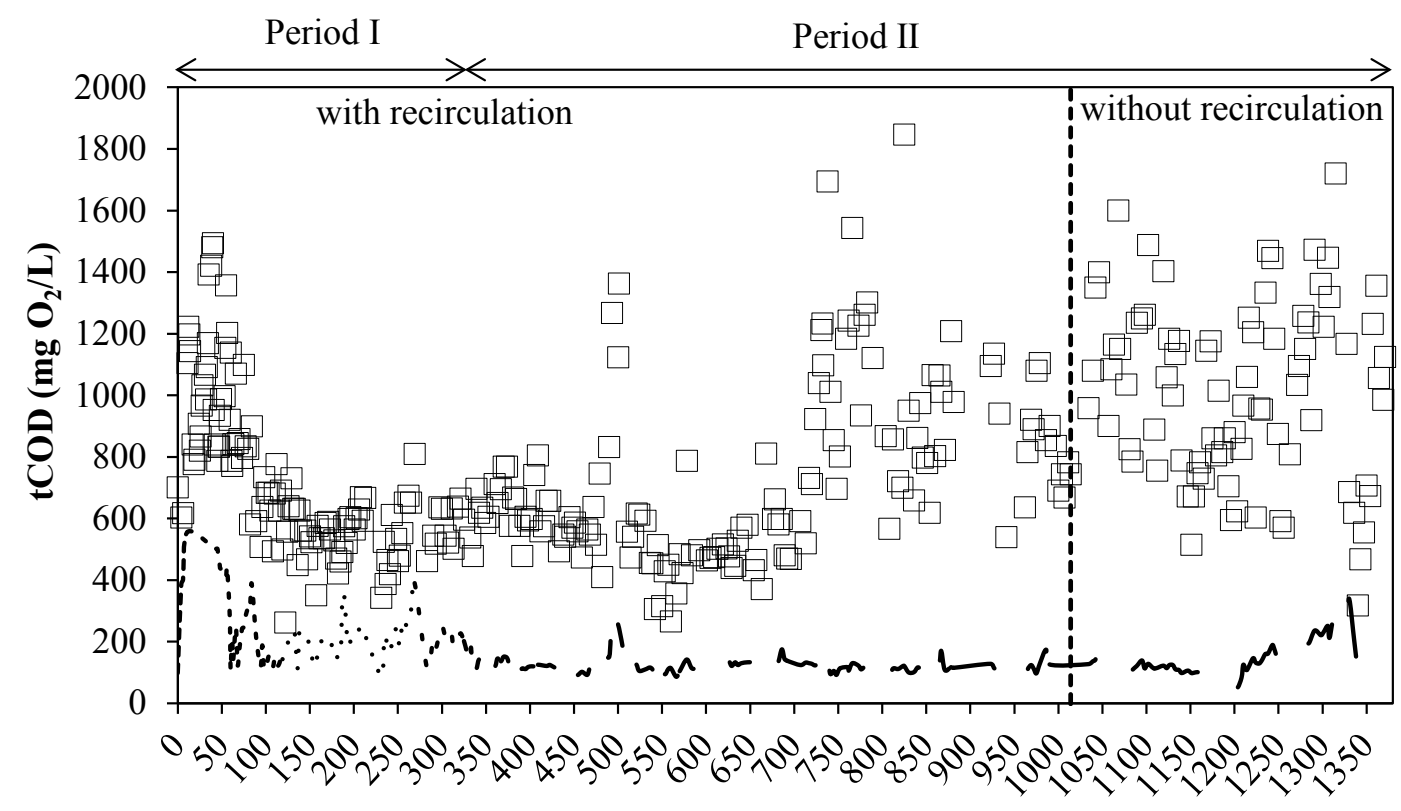

Time (day)

(b)

tCOD influent ------ tCOD effluent

Figure 4.2. (a) Evolution of tCOD removal efficiency of the AnMBR, VLR and HRT of UASB reactor. (b) Evolution of tCOD in the influent and effluent of AnMBR during the entire period of operation. 
The mean value of total VFA in the effluent at a VLR of $2-2.5 \mathrm{~kg} C O D / \mathrm{m}^{3} \mathrm{~d}$ was $21.2 \pm 14.6 \mathrm{mg} / \mathrm{L}$ (composed of acetic, propionic, butyric acid at $68.5 \pm 48.4 \%$, $15.2 \pm 9.5 \%$, and $16.3 \pm 11.1 \%$, respectively). VLRs of $3.5-4.5 \mathrm{~kg} \mathrm{COD} / \mathrm{m}^{3} \mathrm{~d}$ resulted in an increase of VFA, with effluent VFA concentrations of $47.2 \pm 33.4 \mathrm{mg} / \mathrm{L}$.

The results obtained confirmed that AnMBR treating municipal wastewater at psychrophilic temperature $\left(18 \pm 2^{\circ} \mathrm{C}\right)$ achieved effluent tCOD values below the legal discharge limit at HRT of 7-10h and VLRs of $2.5 \mathrm{~kg} \mathrm{tCOD} / \mathrm{m}^{3} \mathrm{~d}$. Similar tCOD removal efficiencies were obtained by Martinez-Sosa et al., (2012), working at $20 \pm 1^{\circ} \mathrm{C}$ with higher HRT (17.76-26.4h) but lowers VLRs $\left(0.4-0.9 \mathrm{~kg}\right.$ COD $\left./ \mathrm{m}^{3} \mathrm{~d}\right)$. Likewise, Smith et al., (2013) also obtained similar COD removal $\left(92 \pm 5 \%\right.$ ) at $15 \pm 1^{\circ} \mathrm{C}$, with a VLR of 0.66 $\mathrm{Kg} \mathrm{COD} / \mathrm{m}^{3} \mathrm{~d}$ and an HRT of $16 \mathrm{~h}$ when working with synthetic wastewater, however with municipal wastewater the COD removal efficiency averaged $69 \pm 10 \%$. Gao et al., ( 2014), working with municipal wastewater at three temperatures $\left(35^{\circ} \mathrm{C}, 25^{\circ} \mathrm{C}\right.$ and $\left.15^{\circ} \mathrm{C}\right)$ with volumetric loading rates between 1.2 and $1.44 \mathrm{~g} \mathrm{COD} / \mathrm{L} \mathrm{d}$ and a HRT of $6 \mathrm{~h}$, reported a decrease in COD removal efficiency in correspondence with temperature, ranging from $74 \%$ to $67 \%$ and $51 \%$ respectively. 
Table 4.2. Principal parameters of operation of AnMBR, (average values).

\begin{tabular}{|c|c|c|c|c|c|c|c|}
\hline $\begin{array}{r}\text { Time } \\
\text { (d) }\end{array}$ & $\begin{array}{l}\text { HRT }_{\text {UASB }} \\
\text { (h) }\end{array}$ & $\begin{array}{c}\text { VLR } \\
\left(\mathrm{gCOD} / \mathrm{L}_{\mathrm{UASB}} \mathrm{d}\right)\end{array}$ & $\begin{array}{c}\text { F/M } \\
\left(\mathrm{gCOD} / \mathrm{gVS}_{\mathrm{UASB}} \mathrm{d}\right)\end{array}$ & $\begin{array}{l}\text { tCOD effluent } \\
(\mathrm{mg} / \mathrm{L})\end{array}$ & $\begin{array}{l}\text { BOD }_{5} \text { effluent } \\
(\mathrm{mg} / \mathrm{L})\end{array}$ & $\begin{array}{c}\text { Biogas } \\
(\mathrm{L} / \mathrm{d})\end{array}$ & $\begin{array}{c}\text { Total removal efficiency } \\
\% \text { tCOD }\end{array}$ \\
\hline $353-381(*)$ & 17.1 & $0.95 \pm 0.09$ & $0.065 \pm 0.013$ & $138 \pm 11.3$ & $52.5 \pm 9.8$ & $29.5 \pm 4.6$ & $79.7 \pm 1.9$ \\
\hline $384-416(*)$ & 16.1 & $0.91 \pm 0.13$ & $0.086 \pm 0.008$ & $119 \pm 10.7$ & $30.3 \pm 4.2$ & $29 \pm 4.8$ & $80.9 \pm 2.5$ \\
\hline $517-553(*)$ & 14.1 & $0.81 \pm 0.18$ & $0.089 \pm 0.007$ & $114 \pm 15.2$ & $34 \pm 3$ & $23.1 \pm 3.3$ & $75.1 \pm 7.4$ \\
\hline $557-584(*)$ & 13.2 & $0.84 \pm 0.28$ & $0.085 \pm 0.010$ & $111 \pm 16.6$ & $33 \pm 1$ & $18.6 \pm 4.7$ & $74.2 \pm 7.9$ \\
\hline $620-720(*)$ & 13.0 & $0.98 \pm 0.21$ & $0.083 \pm 0.010$ & $132 \pm 12.7$ & $47.1 \pm 3.3$ & $22 \pm 8.7$ & $76 \pm 5.2$ \\
\hline $720-748(*)$ & 13.0 & $1.91 \pm 0.51$ & $0.146 \pm 0.046$ & $121 \pm 20.5$ & $47 \pm 9.5$ & $69.1 \pm 14$ & $88.5 \pm 2.7$ \\
\hline 766-789(*) & 11.2 & $2.6 \pm 0.39$ & $0.173 \pm 0.016$ & $121 \pm 12.9$ & $36 \pm 5.7$ & $127.6 \pm 46$ & $90.1 \pm 1.2$ \\
\hline $1063-1095(-)$ & 13.4 & $2.00 \pm 0.43$ & $0.127 \pm 0.026$ & $115 \pm 13.3$ & $43.7 \pm 5.1$ & $83.4 \pm 17.4$ & $89.5 \pm 1.8$ \\
\hline 1109-1137(-) & 10.0 & $2.73 \pm 0.19$ & $0.157 \pm 0.057$ & $117 \pm 6.6$ & $39.8 \pm 7.9$ & $91.5 \pm 18.6$ & $89.8 \pm 1.2$ \\
\hline $1216-1273(-)$ & 7.6 & $3.20 \pm 0.90$ & $0.38 \pm 0.136$ & $160 \pm 22.3$ & $64.1 \pm 12.9$ & $90.8 \pm 10.5$ & $82.9 \pm 4.8$ \\
\hline $1298-1327(-)$ & 7.0 & $4.70 \pm 0.62$ & $0.322 \pm 0.079$ & $226 \pm 13.5$ & $122 \pm 1.4$ & $85.7 \pm 12.4$ & $82.6 \pm 1$ \\
\hline $1328-1354(-)$ & 7.0 & $2.2 \pm 0.85$ & $0.261 \pm 0.140$ & $122 \pm 36$ & $42 \pm 11.5$ & $59.8 \pm 14.9$ & $72.9 \pm 7.8$ \\
\hline 1355-1371(-) & 7.0 & $3.94 \pm 0.45$ & $0.206 \pm 0.085$ & $140 \pm 7.4$ & $46 \pm 16.7$ & $63.8 \pm 15.7$ & $88.6 \pm 2.2$ \\
\hline
\end{tabular}

(*) with recirculation

(-) without recirculation 


\subsubsection{Start up and Sludge Granulation}

The UASB reactor was inoculated with sludge from a mesophilic pilot plant anaerobic digester operating at a SRT of 20 days, fed with primary and secondary sludge from the WWTP of Burgos (Spain) (Period I). After ten months of operation at low temperature with VLR lower than $0.5 \mathrm{~kg} \mathrm{COD} / \mathrm{m}^{3} \mathrm{~d}$, the removal efficiency remained below $60 \%$. The reactor was re-inoculated with sludge from a mesophilic digester from the WWTP of Valladolid (Spain), which allowed the VLR to be increased and supported higher organic matter removal efficiencies (period II). However, this increase in VLR had to be conducted slowly. Hence, a period of six months was needed to reduce the HRT down to $13 \mathrm{~h}$ while maintaining the effluent tCOD at 100-120 $\mathrm{mg} \mathrm{O}_{2} / \mathrm{L}$. In this work, the first inoculation and the re-inoculation were performed without acclimation to psychrophilic conditions, thus entailing long startup periods. Sludge adaptation in the experimental system from mesophilic to psychrophilic conditions involved the loss of active biomass, which, together with the low strength wastewater, was probably responsible for the slow process start up. This period could be reduced in correspondence with a more efficient acclimation to the psychrophilic conditions, by gradually decreasing the temperature. In the work carried out by Gao et al., (2014); Giménez et al., (2012); Martinez-Sosa et al., (2012); Pretel et al., (2014) the startup was carried out at mesophilic conditions and the temperature was decreased stepwise (around $35^{\circ} \mathrm{C}, 25^{\circ} \mathrm{C}, 20^{\circ} \mathrm{C}$ ). Bae et al., (2014) indicate that the results reported were obtained after an acclimation period of 225 days at $25^{\circ} \mathrm{C}$. Also, Shin et al., (2014) working without temperature control $\left(8^{\circ} \mathrm{C}-30^{\circ} \mathrm{C}\right)$, started the reactor during the winter period, reported higher COD removal after full acclimation during the following spring and summer. Moreover, Smith et al., (2013) reported, by comparing bacterial and archaeal microbial communities in the AnMBR after 275 days of inoculation, and in three different inocula, using pyrosequencing to target 16S rRNA genes, that those mesophilic inocula are suitable for seeding psychrophilic AnMBR treating low strength wastewater.

In the present work, granulation of the biomass was observed approximately eight months after re-inoculation, despite the reactor being operated with low superficial rates $(0.15-0.25 \mathrm{~m} / \mathrm{h})$. The presence of the membrane might have contributed to sludge granulation, as it prevented the loss of inorganic material, promoting the formation of granules. These granules remained during the rest of the reactor's operation, co-existing with filamentous bacteria. The color of the granules was black during the entire period 
of operation, and the size was between 1 and $2.5 \mathrm{~mm}$. Controversy still exists in literature regarding the factors affecting anaerobic biomass granulation during the treatment of municipal wastewater (Aiyuk et al., 2006). In some cases, the need to add sugars to facilitate the formation of granules has been reported (Mergaert et al., 1992), and in other cases granulation did not occur in the presence of sugars. Liu et al., (2012), by working in the range of temperature between 27 and $30^{\circ} \mathrm{C}$ and with relation Food/Microorganisms (F/M) of 0.1-3.8 g COD/g SSd, attributed granulation to the high F/M ratio. Aiyuk and Verstraete, (2004), working at $33^{\circ} \mathrm{C}$, with a VLR between 1 and 2 $\mathrm{Kg} \mathrm{COD} / \mathrm{m}^{3} \mathrm{~d}$ and HRT of 4,8 and $10 \mathrm{~h}$ reported loss of granular sludge integrity, while other authors (Ghangrekar et al., 2005) reported granulation at VLRs in the range of 2.0-4.5 kg COD $/ \mathrm{m}^{3} \mathrm{~d}$. Abbasi and Abbasi, (2012) recently analyzed the influence of key operational parameters affecting sludge granulation and granule stability in UASB reactors. They conclude that it is as yet not possible to give a precise recipe adequate for all substrates and reactor operations conditions.

\subsubsection{Solids concentration in the UASB reactor and membrane module}

The concentration of VS was measured at different heights within the UASB reactor, S.p. $0,1,2,3$ and 7 . The variations observed were directly related to the changes in the superficial rate. The concentration of VS at the bottom (S.p. 0) of the reactor ranged from 39 to $45 \mathrm{~g} \mathrm{VS} / \mathrm{L}$, from 7 to $11 \mathrm{~g} \mathrm{VS} / \mathrm{L}$ at the middle height (S.p. 1, 2, 3) and from 1 to $8 \mathrm{~g} \mathrm{VS} / \mathrm{L}$ below the tree phase separator (S.p. 7). Considering the individual volume of each zone, the amount of VS estimated in the UASB remained at 1630-2300 g VS throughout the AnMBR operation. The VS concentration in the central zone of the membrane module also remained constant at $5.95 \pm 2.04 \mathrm{~g} / \mathrm{L}$. No biomass wastage was carried out in the UASB reactor, except for the sampling associated to the monitoring of the different parameters. Purging of solids from the membrane module was carried out during cleaning operation. The total amount of VS wasted from the AnMBR accounted for $0.5 \mathrm{~kg} /$ year due to the sampling and $2.2 \mathrm{~kg} \mathrm{VS} /$ year due to wastage from the membrane module. This represented a negligible growth of the biomass based on the removal of tCOD recorded. Shin et al., (2014), using a pilot scale anaerobic fluidized membrane bioreactor (AFMBR) treating municipal wastewater without temperature control $\left(9-30^{\circ} \mathrm{C}\right)$, obtained a biosolid production average of $0.051 \mathrm{~g} \mathrm{VSS} / \mathrm{g} \mathrm{COD}$ removed independently of the temperature, with a wasting ratio of $1 \%$. The difference observed 
in the biosolid production could be due to the different solid concentration in the bulk liquid in the membrane module, and different SRT. Bae et al., (2014), using synthetic wastewater at $25^{\circ} \mathrm{C}$ in an AFMBR, obtained a sludge production rate of $0.003 \mathrm{~g} \mathrm{VSS} / \mathrm{g}$ $\mathrm{COD}_{\text {removed }}$ with a wasting ratio around $0.8-0.5 \%$. Nevertheless Pretel et al., (2014) reported a sludge production rate of $0.16 \mathrm{TSS} / \mathrm{kg} \mathrm{COD}$ removed, $0.43 \mathrm{TSS} / \mathrm{kg} \mathrm{COD}_{\text {removed }}$ and $0.55 \mathrm{TSS} / \mathrm{kg} \mathrm{COD}$ removed at the respective temperatures of $33^{\circ} \mathrm{C}, 22^{\circ} \mathrm{C}$ and $17^{\circ} \mathrm{C}$ and SRT of 70 days, 38 days and 30 days, working with a semi-industrial AnMBR plant treating sulfate-rich urban wastewater.

\subsubsection{Biogas composition in the UASB reactor and in the membrane module}

Biogas production and biogas composition were periodically measured in the UASB reactor and in the membrane module separately. No significant difference in the biogas composition was observed during the operation with and without recirculation. However, the composition of biogas was slightly different between the UASB reactor and the membrane module. The values of the biogas composition in both periods in the UASB reactor were: $\mathrm{CO}_{2}=7-12 \%, \mathrm{H}_{2} \mathrm{~S}=0.25-0.37 \%, \mathrm{~N}_{2}=5-12 \%$ and $\mathrm{CH}_{4}=80-83 \%$, while in the membrane module biogas was composed of $\mathrm{CO}_{2}=9-13 \%, \mathrm{H}_{2} \mathrm{~S}=0.1-0.3 \%$, $\mathrm{N}_{2}=2-6.5 \%$ and $\mathrm{CH}_{4}=83-86 \%$. These results of biogas composition recorded in the UASB reactor were similar to those reported by Elmitwalli et al., (2002) working with an anaerobic filter+an anaerobic hybrid, at $13^{\circ} \mathrm{C}$ and to the results of Alvarez et al., (2008) working with a hydrolytic upflow sludge bed and UASB at $21-14^{\circ} \mathrm{C}$ treating municipal wastewater. Martinez-Sosa et al., (2012) working with an integrated anaerobic fluidized-bed membrane bioreactor at $20^{\circ} \mathrm{C}$ with municipal wastewater supplemented with glucose also sowed around $80 \%$ of methane in the biogas. Giménez et al., (2012) reported a biogas composition (mean values) of $\mathrm{CO}_{2}=4.4 \%, \mathrm{H}_{2} \mathrm{~S}=1.3 \%$, $\mathrm{N}_{2}=48.6 \%$ and $\mathrm{CH}_{4}=45.7 \%$ working in a semi-industrial SAnMBR treating sulfaterich urban wastewater at $20^{\circ} \mathrm{C}$.

The high values of $\mathrm{N}_{2}$ in the present study, and low values of $\mathrm{CO}_{2}$, were associated with the low total alkalinity of the wastewater, which ranged from $450-550 \mathrm{mg} \mathrm{CaCO} / \mathrm{L}$, whereas total alkalinity in the UASB reactor remained at $450-700 \mathrm{mg} \mathrm{CaCO}_{3} / \mathrm{L}$.

The composition of $\mathrm{CH}_{4}$ was 2-3 percentage points higher in the membrane module than in the UASB reactor. This can be attributed to the higher temperature in the membrane module $\left(1.5-2^{\circ} \mathrm{C}\right)$ than in the UASB reactor due to the turbulence in the 
membrane, both contributing to the desorption of the dissolved methane. Moreover, the contribution of the membrane module's biogas production to the total biogas produced was different with or without recirculation. During process operation with recirculation, the biogas from the membrane module represented $26.4 \%$ of the total biogas production. However, the biogas production of the membrane module represented $13.7 \%$ of the total production during process operation without recirculation. This difference was attributed to the greater amount of liquid flowing to the membrane module during the recirculation period and subjected to the higher turbulence of the membrane module that facilitated the desorption of the dissolved methane in the module. Therefore the membrane operation conditions, at a high rate of biogas sparging, facilitated the recovery of the methane from the AnMBR, which otherwise would be dissolved in the effluent in the UASB reactor due to the low operation temperatures. Thus, the membrane contributed to the reduction of methane dissolved in the effluent of the AnMBR. In this context, Giménez et al., (2012) reported that the biogas-assisted mixing avoided super-saturation and guaranteed the minimum concentration of dissolved methane at the effluent, (i.e. the saturation concentration).

\subsubsection{Specific Methane Yield}

The specific methane yield was calculated from the total production and composition of biogas (UASB reactor and membrane module) and tCOD removed (difference between the tCOD fed to the UASB reactor and tCOD of permeate). The specific methane production obtained throughout the operation of the AnMBR was $0.199 \mathrm{Nm}^{3} \mathrm{CH}_{4} / \mathrm{kg}$ tCOD ${ }_{\text {removed }}$. The SMY was low compared with the theoretical value $\left(0.35 \mathrm{Nm}^{3} \mathrm{CH}_{4} / \mathrm{Kg}\right.$ COD), which was attributed to the fact that not all particulate material retained by the membrane was biodegraded. In AnMBRs, together with the biological removal, a physical removal of particulate matter occurs due to the presence of the membrane, which does not contribute to the production of methane. Hence, a detailed analysis of each operation period reveals differences in the SMY. The SMY during the recirculation period obtained was $0.235 \mathrm{Nm}^{3} \mathrm{CH}_{4} / \mathrm{kg}$ tCOD removed, which compares

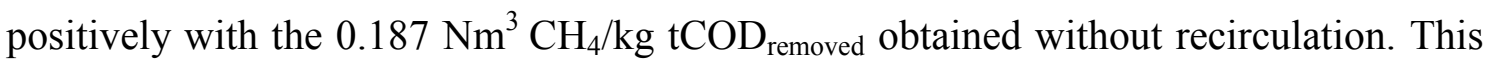
higher productivity $(25.6 \%)$ could be attributed to the partial biodegradation of the slowly biodegradable particulate COD that accumulated in the system. The recirculation of the suspension from the membrane module to the UASB reactor permitted a better 
contact between the biomass and the particulate COD. Therefore, the membrane contributed to the increase in the specific production of methane. The particulate COD, in conventional UASB reactors operated at low temperature, leaving the reactor without significant treatment, with higher HRT being needed, in order to obtain an effluent quality similar to that obtained in the present study. The SMY obtained in this work were in accordance with values reported in literature. The SMP obtained by Ozgun et al., (2013b), in an UASB reactor working at $25 \pm 2^{\circ} \mathrm{C}$ and fed with synthetic wastewater, was $0.13 \mathrm{Nm}^{3} \mathrm{CH}_{4} / \mathrm{kg} \mathrm{COD}_{\text {removed }}$ and $0.11 \mathrm{Nm}^{3} \mathrm{CH}_{4} / \mathrm{kg} \mathrm{COD}$ removed at an upflow velocity of $1.2 \mathrm{~m} / \mathrm{h}$ and $0.6 \mathrm{~m} / \mathrm{h}$, respectively. Gao et al., (2014) obtained a SMY of $0.19 \mathrm{~L} \mathrm{CH}_{4} / \mathrm{g} \mathrm{COD}_{\text {removed, }} 0.19 \mathrm{~L} \mathrm{CH}_{4} / \mathrm{g} \mathrm{COD}_{\text {removed, }}$ and $0.14 \mathrm{~L} \mathrm{CH}_{4} / \mathrm{g} \mathrm{COD}_{\text {removed }}$ working at temperature of $35^{\circ} \mathrm{C}, 25^{\circ} \mathrm{C}$ and $15^{\circ} \mathrm{C}$ respectively, with municipal wastewater. Martinez-Sosa et al., (2012) using an AnSMBR treating low-strength wastewater for 90 days under psychrophilic conditions $\left(20^{\circ} \mathrm{C}\right)$ obtained an average SMY of $0.24 \mathrm{Nm}^{3} \mathrm{CH}_{4} / \mathrm{kg} \mathrm{COD}$ removed. The authors indicated that, even considering the theoretical methane dissolved, calculated according to Henry's law, in the biogas

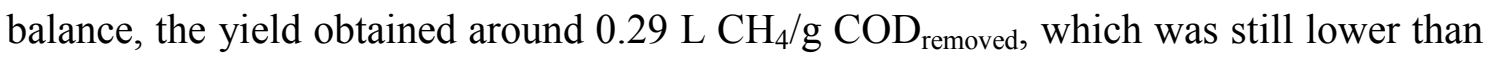
the theoretical value and indicated that particulate or soluble organics were not completely degraded, but physically retained by the membrane.

\subsubsection{Nitrogen and phosphorus removal}

The $\mathrm{N}-\mathrm{TKN}$ and $\mathrm{N}-\mathrm{NH}_{4}{ }^{+}$were determined in the soluble phase of the influent and effluent of the UASB reactor, inside the membrane module and at the effluent from the membrane (Fig. 4.3). Most of the N-TKN in the residual wastewater was present in the form of $\mathrm{N}-\mathrm{NH}_{4}{ }^{+},(\approx 75.45 \pm 0.95 \%$ of the total $\mathrm{N}-\mathrm{TKN})$. There was no significant increase in the concentration of $\mathrm{N}-\mathrm{NH}_{4}{ }^{+}$in the effluent of the AnMBR as a result of the treatment process $(79.84 \pm 2.2 \%$ of the total $\mathrm{N}-\mathrm{TKN})$. However, $\mathrm{N}-\mathrm{TKN}$ accumulated within the membrane module. The concentration of soluble $\mathrm{N}-\mathrm{TKN}$ and $\mathrm{N}-\mathrm{NH}_{4}{ }^{+}$ gradually increased up to $213.58 \mathrm{mg} / \mathrm{L}$ and $104.02 \mathrm{mg} / \mathrm{L}$, respectively, in the membrane module. This increase in nitrogen content throughout the operation of the AnMBR could be due both to the hydrolysis of the accumulated particulate organic matter and also to the cell decay. Phosphorous concentration underwent a similar trend, with no significant difference between the concentration of $\mathrm{P}$ at the soluble phase of the influent and effluent of the AnMBR being recorded. A build-up in P concentration was also 
recorded inside the soluble phase of the membrane module up to $23.8 \pm 14.6 \mathrm{mg} \mathrm{P}-$ $\mathrm{PO}_{4} / \mathrm{L}$. This predictably low removal of nitrogen and phosphorus in the AnMBR could be beneficial if the effluent is to be used for agriculture or irrigation purpose. Lin et al., (2013) suggested that the forward osmosis membrane process could provide another perspective to resolve this challenge, since the FO process can almost totally reject $\mathrm{N}$ and $\mathrm{P}$ contaminants. In this respect, an increase in TNK and $\mathrm{NH}_{4}{ }^{+}$concentration in the membrane module was observed by Chen et al., (2014), in a FO-AnMBR at $25^{\circ} \mathrm{C}$ treating synthetic wastewater, achieving nearly $100 \%$ total phosphorus removal and $62 \% \mathrm{~N}-\mathrm{NH}_{4}^{+}$removal.

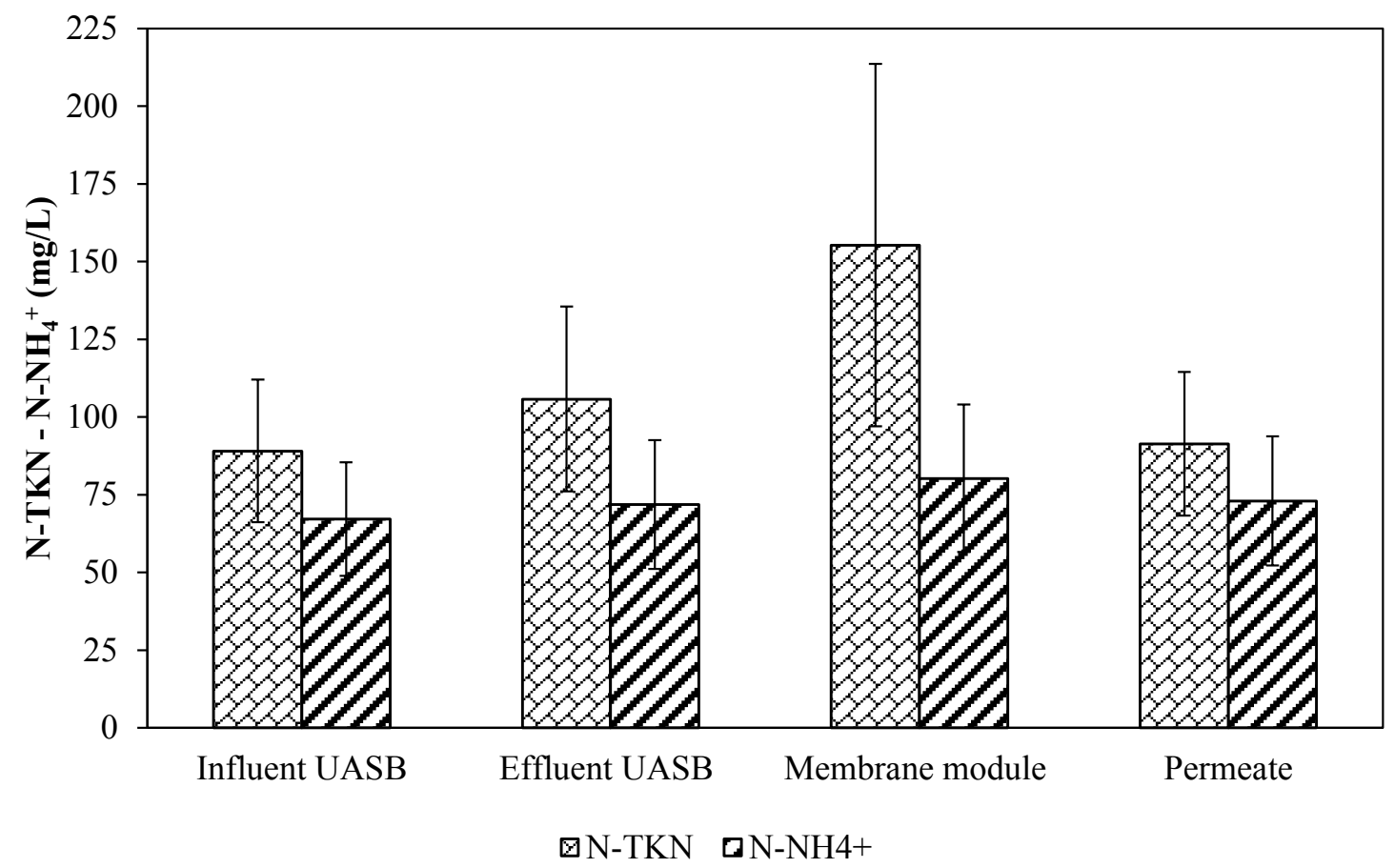

Figure 4.3. $\mathrm{N}-\mathrm{TKN}, \mathrm{N}-\mathrm{NH}_{4}{ }^{+}$concentration in the AnMBR (mean values) during the entire period of operation. 


\subsubsection{Accumulation of particulate COD}

One of the fundamental effects of the functioning membrane was the accumulation of particulate COD inside the system. Fig. 4.4 shows a clear difference between the values of sCOD inside the membrane module and the tCOD in the AnMBR effluent. This difference, caused by the different porous diameter of lab filter for $\operatorname{SCOD}(0.45 \mu \mathrm{m})$ and the membrane $(0.04 \mu \mathrm{m})$, generates a very high quality effluent, and the subsequent accumulation in the membrane module of non-biodegradable matter and the slowly biodegradable particulate COD. The sCOD in the membrane module increased up to 4000 and $6000 \mathrm{mg} / \mathrm{L}$ during the period with recirculation and without recirculation, respectively, while the tCOD in the effluent remained at $100-120 \mathrm{mg} / \mathrm{L}$. The particulate COD in the range of 0.45 microns to 0.04 microns is slowly biodegradable and nonsettleable at low temperatures due both to its size and to the high turbulence existing in the central zone of the membrane module. This accumulation increased with the increase of the VLR and depended on the content of particulate matter of the wastewater. In fact, the higher values of SCOD corresponded to VLR ranging from 3.5 to $5 \mathrm{~kg} \mathrm{COD} / \mathrm{m}^{3} \mathrm{~d}$. The decrease in accumulated COD values was due either to the purging of the membrane module or to the cleaning of the membrane. This accumulation of particulate // colloidal material was also reported in recent literature, independently of the use of micro or ultrafiltration membranes. Bae et al., (2014) working with synthetic wastewater at $25^{\circ} \mathrm{C}$ in an anaerobic fluidized membrane bioreactor, using a PVDF membrane with a pore size of 0.1 microns, reported that the sCOD of the bulk liquid was 10-26 times higher than that of the permeate. MartinezSosa et al., (2012) also concluded that organic compounds were not completely degraded, but physically retained by the membrane. Moreover Shin et al., (2014) suggests that the limiting steps in organic degradation at low temperature are the hydrolysis of VSS and colloidal materials rather than methanogenesis. 


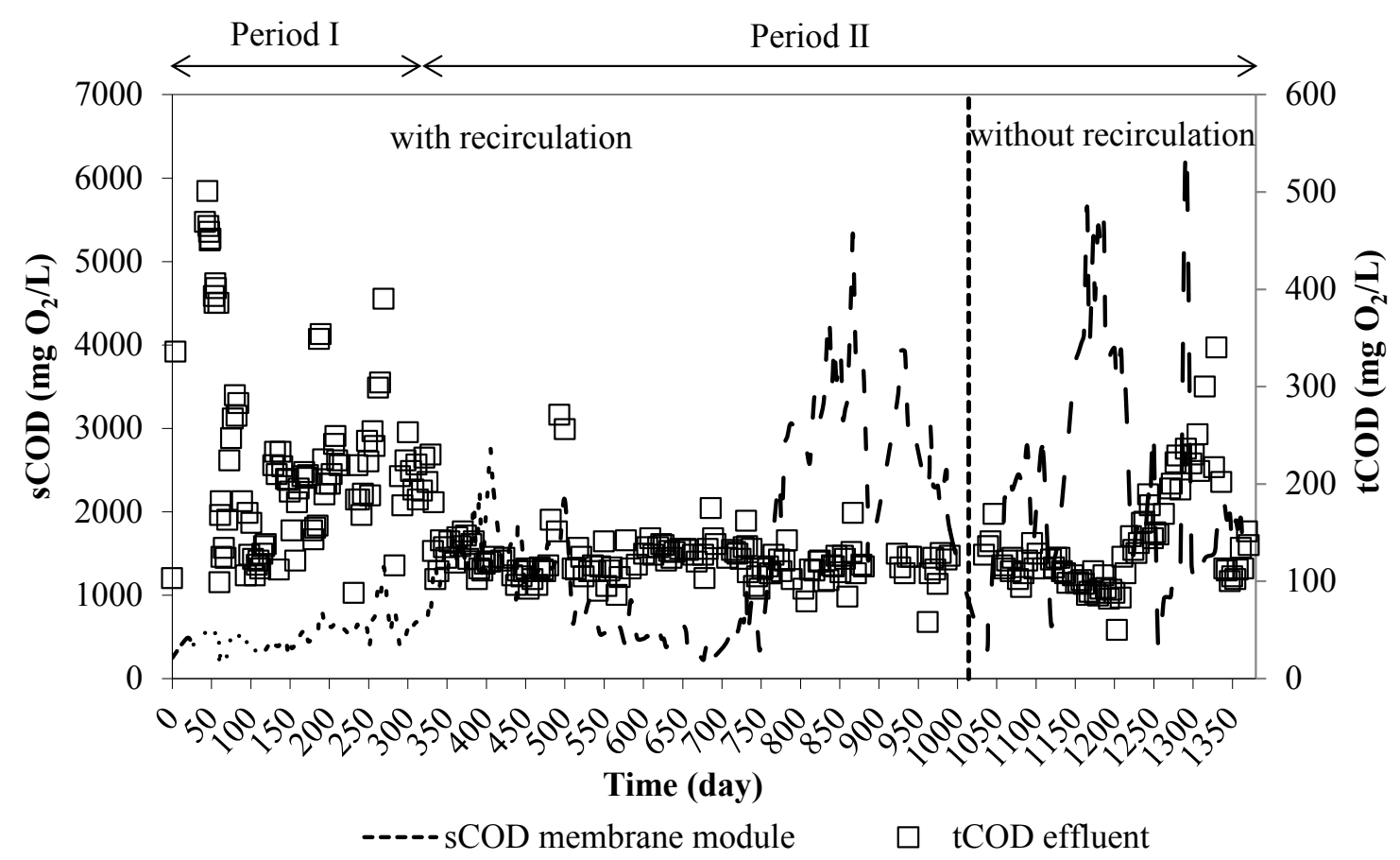

Figure 4.4. Evolution of SCOD accumulation in the membrane module and $t \mathrm{COD}_{\text {effluent }}$ during the entire period of operation.

\subsubsection{Biochemical methane potential assay of accumulated particulate matter}

To facilitate membrane filtration and to reduce the fouling, several purges of the membrane module were carried out in order to eliminate accumulated material. The purges were carried out every time the membrane module was chemically cleaned. Every time, the volume purged was around $145 \mathrm{~L}$ and the amount of volatile solids purged was $1 \mathrm{~kg}$ (mean value). The BMP from the accumulated material in the membrane module was carried out in order to determine the mesophilic anaerobic biodegradability, envisaging a process configuration where the solids wasted (purges) from the anaerobic membrane module at psychrophilic temperature could be further stabilized in a mesophilic anaerobic digester. The specific methane yield by day 17 was $417.65 \mathrm{~mL} \mathrm{CH}_{4} / \mathrm{g} \mathrm{VS}_{\text {fed }}$ for the suspension, $390.21 \mathrm{~mL} \mathrm{CH}_{4} / \mathrm{g} \mathrm{VS}_{\text {fed }}$ for the concentrated solid and $166.93 \mathrm{~mL} \mathrm{CH}_{4} / \mathrm{g} \mathrm{VS}_{\text {fed }}$ for the supernatant. Thus, the mesophilic biodegradability of this particulate organic matter present in the suspension, in the concentrated sludge and in the supernatant was $56.81 \%, 38.84 \%$ and $28.30 \%$, respectively. 


\subsubsection{Membrane behavior}

Fig. 4.5 illustrates the performance of the membrane throughout the operation of the AnMBR. Biogas was continuously sparged (coarse bubbles) at the bottom of the hollow fibbers with a superficial velocity $\left(\mathrm{u}_{\mathrm{g}}\right)$ of $23 \mathrm{~m} / \mathrm{h}$. During period $\mathrm{I}$, the low solid concentration $(<0.5 \mathrm{~g} / \mathrm{L})$ and the low flux resulted in a low TMP (50 mbar). Nevertheless, solid concentration inside the membrane module increased up to 5-7 $\mathrm{g}$ $\mathrm{VSS} / \mathrm{L}$ during period II, which together with the increase in the permeate flow, entailed a significant increase in the TMP and a subsequent increase in $u_{g}$ to $40-60 \mathrm{~m} / \mathrm{h}$. The filtration cycle was then decreased to 7.5 minutes filtration, 15 seconds back-flush and 10 seconds of relaxation time in order to maintain the TMP and to reduce membrane fouling. The membrane module operated at high fluxes of permeate, $14-15 \mathrm{~L} / \mathrm{m}^{2} \mathrm{~h}$ (recirculation period) and $10-12 \mathrm{~L} / \mathrm{m}^{2} \mathrm{~h}$ (without recirculation), which resulted in TMPs ranging from 500 to 550 mbar (Fig. 5.5), with specific gas demand per membrane area of between $0.4-1 \mathrm{Nm}^{3} / \mathrm{m}^{2} \mathrm{~h}$. During the last stage of the work, the permeate flow along the cycle was inconstant, decreasing slightly at around $1-2 \%$. The permeate fluxes obtained are higher than those reported in literature, considering the long-term operation of the membrane. Smith et al., (2012) reported, in a recent review, sub-critical fluxes values of 7,10 and $17 \mathrm{~L} / \mathrm{m}^{2} \mathrm{~h}$, depending on operation conditions, solid concentration, SRT, and the methodology followed to control the fouling. Nevertheless, these fluxes are still low compared with those obtained in the aerobic membrane bioreactor (Lin et al., 2013; Smith et al., 2012). Robles et al., (2012) also reported a high flux of around 13-10 L/m $\mathrm{m}^{2} \mathrm{~h}$, with solid concentrations of between 10 and $25 \mathrm{~g} / \mathrm{L}$, and temperatures in the range of $33-20^{\circ} \mathrm{C}$ with an average specific gas demand per membrane area of $0.23 \mathrm{Nm}^{3} / \mathrm{m}^{2} \mathrm{~h}$.

In the present study, the membrane was chemically cleaned seven times, throughout the operation period. This represents a cleaning session approximately every six months of operation. The cleaning was carried out using $1000 \mathrm{ppm}$ of $\mathrm{NaClO}$ for between 4 and 6 hours and at room temperature. After these cleaning periods, the permeability reached a value of $0.128 \mathrm{~L} / \mathrm{m}^{2} \mathrm{~h}$ mbar, representing a recovery of $61.4 \%$ of the initial permeability. Physical deterioration of the fibers was not observed during the long-term operation of the AnMBR. Lin et al., (2013) reported that the typical cleaning protocol used in AnMBRs comprised a weekly clean in place, and a cleaning out of place using $1000 \mathrm{mg} / \mathrm{L} \mathrm{NaClO}$ and $2000 \mathrm{mg} / \mathrm{L}$ citric acid, conducted twice yearly. Nevertheless, in 
the present study only chemical cleaning out place was carried out. Shin et al., (2014), working with a pilot scale anaerobic fluidized membrane bioreactor (AFMBR), used only the scouring effect of the fluidized GAC and relaxation, to prevent fouling. Their AFMBR operated continuously for 485 days at net fluxes of $4.1-7.1 \mathrm{~L} / \mathrm{m}^{2} \mathrm{~h}$, and no chemical cleaning was carried out during the entire period. Although the authors suggested that, the chemical cleaning of the membrane would have been desirable once quarterly. Nevertheless, Robles et al., (2012) reported that, no chemical cleaning was conducted during system operating for more than one year.

The behavior obtained in the present study demonstrates the long-term reliability and operability of the AnMBR technology for treating municipal wastewater in psychrophilic conditions. The quality of the effluent, free from solids and mineralized nutrients, makes it suitable for irrigation or agricultural purposes, or for nutrient recovery. Nevertheless more research should be conducted on dissolved methane losses in the effluent, the optimum SRT in the AnMBR, and the optimal operation protocol in order to increase the permeate flux and the economic feasibility of the AnMBR.

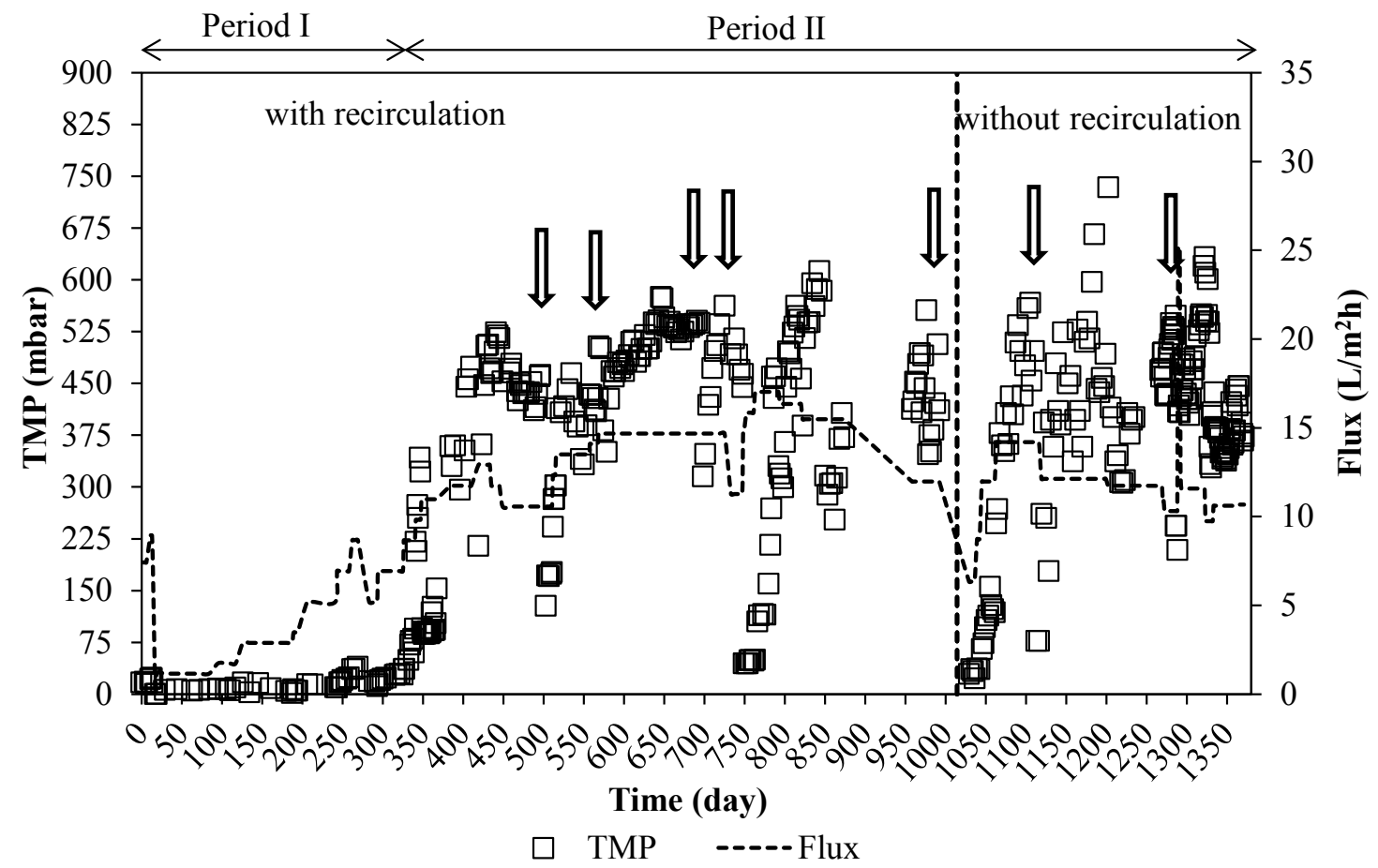

Figure 4.5. Evolution of TMP and permeate flux during the entire period of operation (arrows indicate the chemical cleaning). 


\subsection{Conclusions}

The results obtained for the long-term operation show the feasibility of the AnMBR technology for the treatment of municipal wastewater at psychrophilic temperature. Operating at VLR between 2 and $2.5 \mathrm{~kg} \mathrm{tCOD} / \mathrm{m}^{3} \mathrm{~d}$ and HRT of $7 \mathrm{~h}$, the tCOD removal efficiencies obtained were $87 \pm 1 \%$, and reaching values of tCOD in the effluent of $100-120 \mathrm{mg} \mathrm{O}_{2} / \mathrm{L}$. The specific methane yield obtained was 0.18 and $0.23 \mathrm{Nm}^{3} \mathrm{CH}_{4} / \mathrm{kg}$ $\mathrm{COD}_{\text {removed }}$ depending on the recirculation between the membrane module and the UASB reactor. The membrane operated with flux of between 10 and $14 \mathrm{~L} / \mathrm{m}^{2} \mathrm{~h}$ during the three years of stable operation, requiring chemical cleaning every six months. 


\subsection{Acknowledgements}

This work was part of the project IPT-2011-1078-310000 led by CADAGUA and supported by the Spanish Ministry of the Environment. The ultrafiltration membrane module (ZW-10 Zenon) was supplied by General Electric. The Environmental Technology group of Valladolid University is a member of the Consolider-Novedar programme and has been nominated as a "Grupo de Excelencia" by the Regional Government of Castilla y León (GR 76). 


\subsection{References}

Abbasi, T., Abbasi, S. a., 2012. Formation and impact of granules in fostering clean energy production and wastewater treatment in upflow anaerobic sludge blanket (UASB) reactors. Renew. Sustain. Energy Rev. 16, 1696-1708.

Aiyuk, S., Forrez, I., Lieven, D.K., van Haandel, A., Verstraete, W., 2006. Anaerobic and complementary treatment of domestic sewage in regions with hot climates-A review. Bioresour. Technol. 97, 2225-2241.

Aiyuk, S., Verstraete, W., 2004. Sedimentological evolution in an UASB treating SYNTHES, a new representative synthetic sewage, at low loading rates. Bioresour. Technol. 93, 269-278.

Alvarez, J. a, Armstrong, E., Gómez, M., Soto, M., 2008. Anaerobic treatment of lowstrength municipal wastewater by a two-stage pilot plant under psychrophilic conditions. Bioresour. Technol. 99, 7051-7062.

APHA., AWWA. and WPCF., 2005. Standard Methods for the Examination of Water and Wastewater., 21st ed. American Public Health Association, Washington DC. USA.

Bae, J., Shin, C., Lee, E., Kim, J., McCarty, P.L., 2014. Anaerobic treatment of lowstrength wastewater: A comparison between single and staged anaerobic fluidized bed membrane bioreactors. Bioresour. Technol. 165, 75-80.

Baek, S.H., Pagilla, K.R., 2006. Aerobic and anaerobic membrane bioreactors for municipal wastewater treatment. Water Environ. Res. 78, 133-140.

Chen, L., Gu, Y., Cao, C., Zhang, J., Ng, J.-W., Tang, C., 2014. Performance of a submerged anaerobic membrane bioreactor with forward osmosis membrane for low-strength wastewater treatment. Water Res. 50, 114-123.

Chernicharo, C., Machado, R., 1998. Feasibility of the uasb/af system for domestic sewage treatment in developing countries. Water Sci. Technol. 38, 325-332. 
Elmitwalli, T. a, Oahn, K.L.T., Zeeman, G., Lettinga, G., 2002. Treatment of domestic sewage in a two-step anaerobic filter/anaerobic hybrid system at low temperature. Water Res. 36, 2225-2232.

Gao, D.-W., Hu, Q., Yao, C., Ren, N.-Q., 2014. Treatment of domestic wastewater by an integrated anaerobic fluidized-bed membrane bioreactor under moderate to low temperature conditions. Bioresour. Technol. 159, 193-198.

Ghangrekar, M.M., Asolekar, S.R., Joshi, S.G., 2005. Characteristics of sludge developed under different loading conditions during UASB reactor start-up and granulation. Water Res. 39, 1123-1133.

Giménez, J.B., Martí, N., Ferrer, J., Seco, A., 2012. Methane recovery efficiency in a submerged anaerobic membrane bioreactor (SAnMBR) treating sulphate-rich urban wastewater: evaluation of methane losses with the effluent. Bioresour. Technol. 118, 67-72.

Ho, J., Sung, S., 2010. Methanogenic activities in anaerobic membrane bioreactors (AnMBR) treating synthetic municipal wastewater. Bioresour. Technol. 101, 2191-2196.

Kocadagistan, E., Topcu, N., 2007. Treatment investigation of the Erzurum City municipal wastewaters with anaerobic membrane bioreactors. Desalination 216, $367-376$.

Lettinga, G., Rebac, S., Zeeman, G., 2001. Challenge of psychrophilic anaerobic wastewater treatment. Trends Biotechnol. 19, 363-370.

Liao, B.Q., Kraemer, J.T., Bagley, D.M., 2006. Anaerobic Membrane Bioreactors: Applications and Research Directions. Crit. Rev. Environ. Sci. Technol. 36, 489530.

Lin, H., Peng, W., Zhang, M., Chen, J., Hong, H., Zhang, Y., 2013. A review on anaerobic membrane bioreactors: Applications, membrane fouling and future perspectives. Desalination 314, 169-188. 
Liu, Y., Liu, H., Cui, L., Zhang, K., 2012. The ratio of food-to-microorganism (F/M) on membrane fouling of anaerobic membrane bioreactors treating low-strength wastewater. Desalination 297, 97-103.

Martinez-Sosa, D., Helmreich, B., Horn, H., 2012. Anaerobic submerged membrane bioreactor (AnSMBR) treating low-strength wastewater under psychrophilic temperature conditions. Process Biochem. 47, 792-798.

Martinez-Sosa, D., Helmreich, B., Netter, T., Paris, S., Bischof, F., Horn, H., 2011. Anaerobic submerged membrane bioreactor (AnSMBR) for municipal wastewater treatment under mesophilic and psychrophilic temperature conditions. Bioresour. Technol. 102, 10377-10385.

Mergaert, K., Vanderhaegen, B., Verstraete, W., 1992. Review Paper Pre-Treatment of Municipal Wastewater 26, 1025-1033.

Metcalf and Eddy, 2003. Wastewater Engineering, treatment and reuse. McGraw-Hill. Four Edition.

Ozgun, H., Kaan, R., Evren, M., Kinaci, C., Spanjers, H., Lier, J.B. Van, 2013a. A review of anaerobic membrane bioreactors for municipal wastewater treatment: Integration options, limitations and expectations. Sep. Purif. Technol. 118, 89-104.

Ozgun, H., Ersahin, M.E., Tao, Y., Spanjers, H., van Lier, J.B., 2013b. Effect of upflow velocity on the effluent membrane fouling potential in membrane coupled upflow anaerobic sludge blanket reactors. Bioresour. Technol. 147, 285-292.

Pretel, R., Robles, A., Ruano, M. V, Seco, A., Ferrer, J., 2014. The operating cost of an anaerobic membrane bioreactor (AnMBR) treating sulphate-rich urban wastewater. Sep. Purif. Technol. 126, 30-38.

Rittmann, B.E., McCarty, P.L., 2001. Environmental Biotechnology: Principles and Applications. McGraw-Hill Companies.

Robles, A., Ruano, M.V., Ribes, J., Ferrer, J., 2012. Sub-critical long-term operation of industrial scale hollow-fibre membranes in a submerged anaerobic MBR (HFSAnMBR) system. Sep. Purif. Technol. 100, 88-96. 
Santos, a., Ma, W., Judd, S.J., 2011. Membrane bioreactors: Two decades of research and implementation. Desalination 273, 148-154.

Shin, C., Mccarty, P.L., Kim, J., Bae, J., 2014. Pilot-scale temperate-climate treatment of domestic wastewater with a staged anaerobic fluidized membrane bioreactor (SAF-MBR). Bioresour. Technol. 159, 95-103.

Smith, A.L., Skerlos, S.J., Raskin, L., 2013. Psychrophilic anaerobic membrane bioreactor treatment of domestic wastewater. Water Res. 47, 1655-1665.

Smith, A.L., Stadler, L.B., Love, N.G., Skerlos, S.J., Raskin, L., 2012. Perspectives on anaerobic membrane bioreactor treatment of domestic wastewater: a critical review. Bioresour. Technol. 122, 149-159.

Van Lier, J.B., Tilche, a, Ahring, B.K., Macarie, H., Moletta, R., Dohanyos, M., Pol, L.W., Lens, P., Verstraete, W., 2001. New perspectives in anaerobic digestion. Water Sci. Technol. 43, 1-18.

Wiegant, W.M., 2001. Experiences and potential of anaerobic wastewater treatment in tropical regions. Water Sci. Technol. 44, 107-113 



\section{CHAPTER 5}

\section{Specific cake resistance}





\subsection{Introduction}

The principal disadvantage is the fouling of the membrane. From a physico chemical point of view, such fouling in AnMBR has been found to be highly influenced by a number of biotic (bacteria, protozoa and phytoplankton) and abiotic parameters. The principal biotic parameter is the concentration of microorganisms. With a size of $0.1-15$ $\mu \mathrm{m}$, micro organisms are totally retained by $\mathrm{MF}(\geq 0.1 \mu \mathrm{m})$ and $\mathrm{UF}(0.01-0.1 \mu \mathrm{m})$ membranes (Charfi et al., 2012).

Laspidou and Rittmann, (2002) considers the products of the metabolism of microorganisms like extracellular polymeric substances (EPS), including bound EPS and soluble EPS also known as soluble microbial products (SMP), are also considered as principal fouling agents. According to some authors (Gao et al., (2010); Lin et al., (2009)), bound EPS enables microorganisms to adhere to a membrane and to aggregate and form a biofilm. Abiotic parameters also have a great impact on fouling. High temperatures reduce particle size, leading to smaller and denser aggregate structure (Lin et al., 2009; Massé et al., 2006). Other important parameter conditioning the fouling of membranes in an AnMBR is the TSS concentration; when high, it leads to a sudden, rapid fouling (Ho and Sung, 2009). Other parameter which seems to be crucial to membrane fouling is the optimization of the SRT. A short SRT prevents the hydrolysis of organic matter which can lead to rapid membrane fouling (Trzcinski and Stuckey, 2010; Nghiem et al., 2006). On the other hand, a very long SRT (>50days) will cause an increase in the viscosity of the sludge and, consequently, a rapid increase in resistance at the membrane's surface with a consequent significant drop in the permeate flux (He et al., 2005).

According to Lee et al., (2003) and Liao et al., (2006), high SRTs correspond to more biogas production due to the improved stabilization of organic matter by overcoming hydrolysis limitations, less sludge production and higher biomass concentrations in the reactor, and increased SRTs also yield to sludge stabilization, which means less active biomass and accumulation of inert organic and inorganic matter. Unfortunately, it is very difficult to assess and evaluate the impact of SRT on membrane fouling since many parameters, i.e. biomass concentration, sludge viscosity, F:M ratio and EPS concentrations, which are also related to fouling, inevitably change depending on the variations of this parameter. 


\subsubsection{Specific cake resistance ( $\alpha)$}

Cake layer formation is generally regarded as the most important fouling mechanism in AnMBRs. Therefore, the parameter $\alpha$, indicating the sludge filterability, may also indicate the quality of cake accumulating on the membrane surface. Thus a lower specific cake resistance means a compact and less porous cake layer formed with smallsized particles, whereas a higher $\alpha$ indicates a cake layer with high porosity (Dereli et al., 2014).

During a filtration process, the flux is related to cake and membrane resistance through the resistance in series model:

$\mathrm{J}=\frac{1}{\mathrm{~A}} \frac{\mathrm{dV}}{\mathrm{dt}}=\frac{\mathrm{TMP}}{\mu} \frac{1}{\mathrm{R}_{\mathrm{M}}+\mathrm{R}_{\mathrm{C}}}$

where $A$ represents the membrane area, $V$ the permeate volume, $t$ the time, $R_{M}$ the apparent membrane resistance and the $\mathrm{R}_{\mathrm{C}}$ the cake resistance. In a dead-end filtration, cake resistance is related to the specific cake resistance $(\alpha, \mathrm{m} / \mathrm{Kg})$ through the amount of deposited particles (Perry and Green, 1999).

$\mathrm{R}_{\mathrm{C}}=\frac{\mathrm{V}}{\mathrm{A}} \alpha \cdot \mathrm{C}$

where $\mathrm{C}$ represents the solids concentration. If $\mathrm{R}_{\mathrm{C}}$ from Eq. (2) is substituted in Eq. (1), and a constant flux is assumed, we obtain

$\mathrm{TMP}=\frac{\mu \cdot \alpha \cdot \mathrm{C} \cdot \mathrm{J}}{\mathrm{A}} \mathrm{V}+\mu \cdot \mathrm{R}_{\mathrm{M}} \cdot \mathrm{J}$

The specific cake resistance is then determined through the evaluation of the slope of a plot of TMP against permeate volume (Fig. 5.1). 


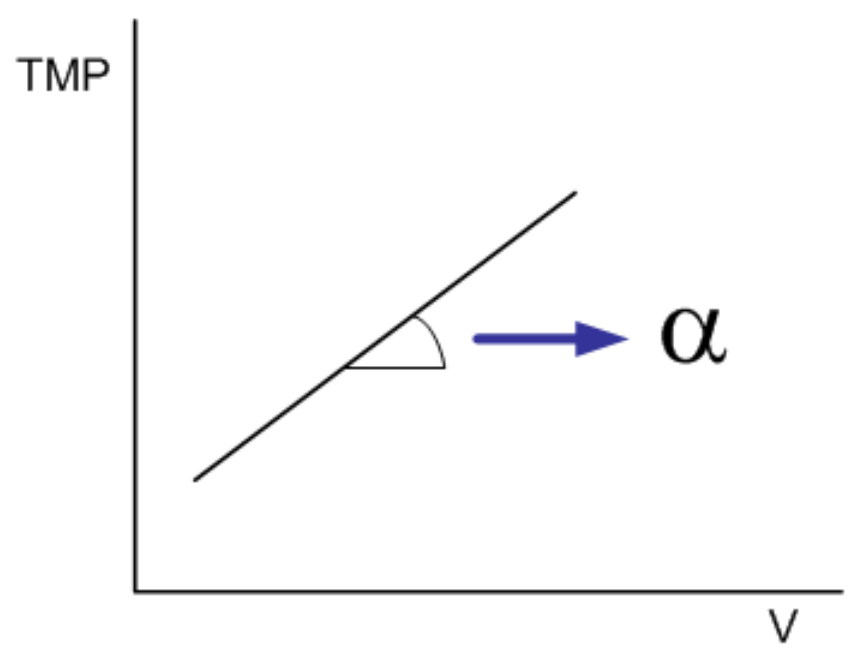

Figure 5.1. Diagram of the slope to determine the specific cake resistance.

The extreme conditions ( $\mathrm{pH}$ and temperature) related to AnMBR treatment will induce decreased particle size distribution (PSD) of sludge liquor, which in turn negatively affect membrane fouling (Lin et al., 2013). The cake layer deposited on the membrane surface in the aerobic SMBR system has a filtration resistance of around $10^{14} \mathrm{~m} / \mathrm{kg}$ (Chu and $\mathrm{Li}, 2005$ ), which is much higher than the value of $10^{11} \mathrm{~m} / \mathrm{kg}$ determined for activated sludge during dewatering (Buyukkamaci, 2004). In SMBR systems, small flocs only account for a small fraction of the total sludge suspension in terms of volume, while they seem to take major responsibility for the membrane fouling in SMBR systems (Wisniewski and Grasmick, 1998; Ng and Hermanowicz, 2005). According to Li et al., (2011), the particle size of the flocs alone could not satisfactorily explain the observation that small flocs play a critical role on membrane fouling.

The addition of Coagulants/Flocculants and addition of Adsorbents/Flux Enhancers, being the objective reduce the amount of colloidal material in the area of the membrane and increase the flux of the membrane (Akram and Stuckey, 2008; Hu and Stuckey, 2007; Wu et al., 2009).

\subsubsection{Coagulant/Flocculants}

Coagulation it's described as the agent induced aggregation of particles suspended in liquid media into larger particles, and favoring with the help of slow stirring, the contacts between the destabilized particles, forming flocs that are more easily removed (Desai and Sahu, 2014). 
Flocculation is the action of polymers to form bridges between the flocs and bind the particles into large agglomerates or clumps. Bridging occurs when segments of the polymer chain adsorb on different particles and help particles aggregate (Wang et al., 2005; Migo et al., 1993). Once suspended particles are flocculated into larger particles, they can usually be removed from the liquid by sedimentation, provided that a sufficient density difference exists between the suspended matter and the liquid. The process of coagulation/flocculation consists of three steps: coagulation of the suspended solids, growing of the microflocs and elimination of the floc aggregates formed (Ryan et al., 2008).

\subsubsection{Adsorbent/Flux Enhancers}

There are membrane performance enhancers, which can be added to the membrane tank, to improve the filtration process. The Membrane Performance Enhancer (MPE) technology reduced membrane fouling significantly while not affecting the membranes with negative zeta-potentials (Yoon et al, 2005; Hwang et al., 2007). The MPE is able to increase the porosity of the cake layer formed on the membrane surface and results in higher permeability and less chemical cleanings (Hwang et al., 2007). There are different commercial houses that offer these products. According to Nalco the characteristics and targets of MPE-technology are:

- Significant increase of the permeability

- Compatibility with all main membranes in the MBR market

- Significant increase for peak and average flow

- Reduction of the transmembrane pressure

- Biological degradation

- Reduction of EPS

- Significant reduction of fine particles

- Reduction of the chemical cleaning frequency 


\subsection{Objectives}

The purpose of this study was determine the specific cake resistance from different sampling points of the UASB reactor and membrane tank, in the AnMBR pilot plant during the period of operation. Determine if the addition of a Membrane Performance Enhancer (cationic polymer PermaCare MPE50 ${ }^{\mathrm{TM}}$ ), enhances or not the process of membrane filtration, at lab-scale and in the pilot plant, respectively.

\subsection{Material and Methods}

The sludge analyzed was obtained from the AnMBR of the following sampling points: biological reactor (S.p.1, S.p.7 and upper part of internal 3-phase separator (S.p.bell)) and filtration unit (S.p.6). A cationic polymers $M P E 50^{\mathrm{TM}}$ wich contains a Polyquaternary Amine, from Nalco, was used.

\subsubsection{Critical flux measurement}

The critical flux was determined applying a flux step method (Le Clech et al., 2003). It consisted of successive filtration steps of $10 \mathrm{~min}$, with flux increments of $2 \mathrm{~L} / \mathrm{m}^{2} \mathrm{~h}$ and a gas superficial velocity of $0.035 \mathrm{~m} / \mathrm{h}$. One minute of back-flush was included between each cycle. Critical flux measurement automatically stopped when TMP reached 150 mbar. The critical flux was assumed to be exceeded when the slope of the TMP against time failed a hypothesis test, with null hypothesis $\mathrm{dTMP} / \mathrm{dt}=0$ (Montgomery et al., 2001). The critical flux indicates the flux at which cake layer formation becomes noticeable.

\subsubsection{Specific cake resistance $(\alpha)$}

The specific cake resistance of sludge samples (S.p.1, S.p.7, S.p.bell, and S.p.6) was measured in a filtration unit, without gas sparging. A single hollow fiber membrane tube of $459 \mathrm{~mm}$ length and $18.6 \mathrm{~mm}$ diameter, with a useful area of $0.00268 \mathrm{~m}^{2}$, was used for this purpose (Fig. 5.2). The single hollow fiber was placed in a filtration unit (height $600 \mathrm{~mm}$, internal diameter $33.9 \mathrm{~mm}$ ) with a useful volume of $0.66 \mathrm{~L}$, wich contained the sludge. Measurements were performed at $18 \pm 2^{\circ} \mathrm{C}$. The single hollow fiber used for cake resistance determination had the same characteristics as those used for the operation of 
the reactors. Filtration was performed at different flux between 6 and $25 \mathrm{~L} / \mathrm{m}^{2} \mathrm{~h}$, by means of a peristaltic pump that collected the permeate from the membrane. TMP was measured by a pressure sensor located in the permeate line. Measurements were performed in duplicates and at a constant concentration of volatile solids.

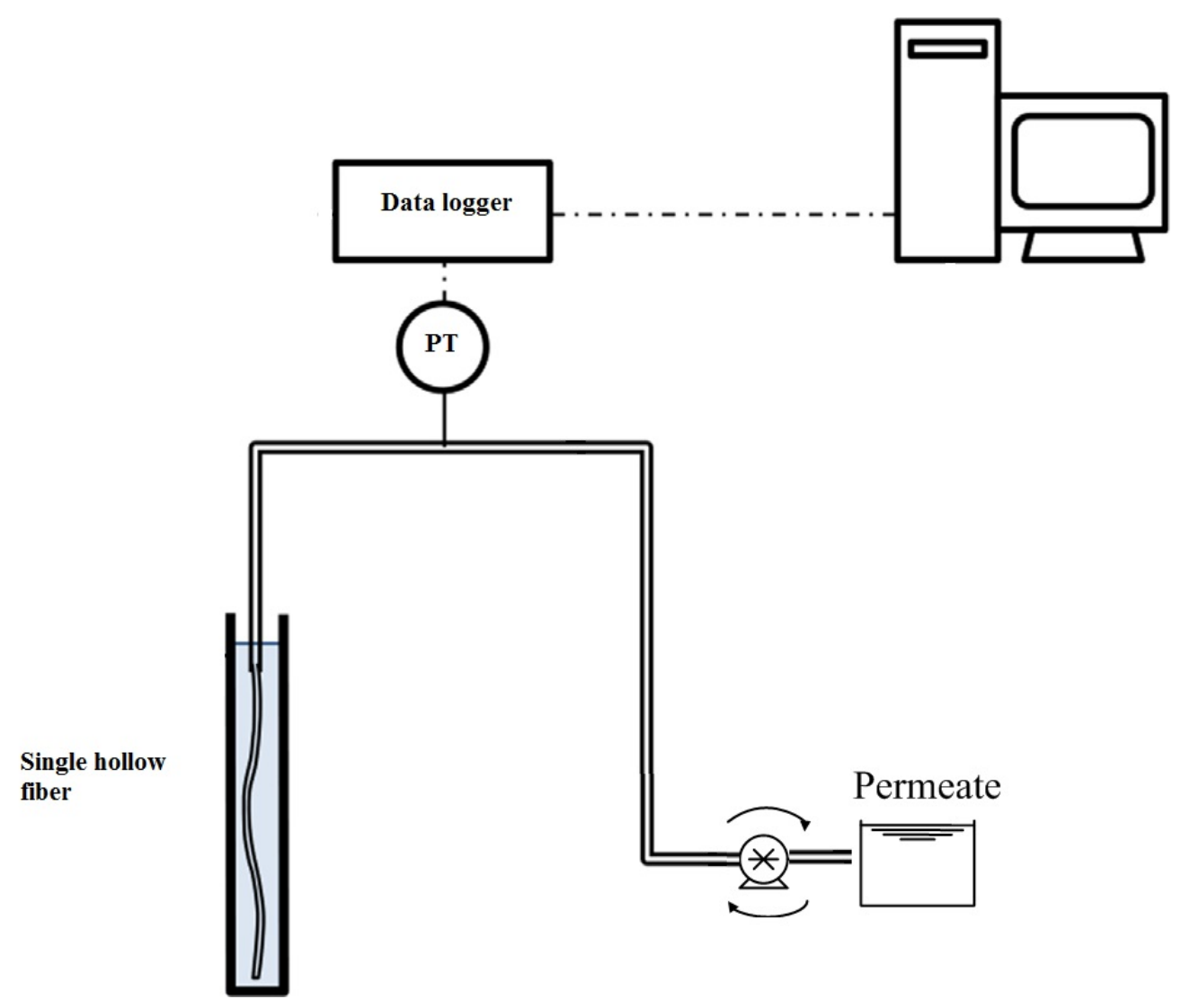

Figure 5.2. Diagram of the setup for measurement the specific cake resistance.

\subsubsection{Jar-test}

The mixing conditions used for the cationic polymer (PermaCare MPE50 ${ }^{\mathrm{TM}}$ ), were 10 min rapid mixing at 180 r.p.m. to mix very well the MPE50 ${ }^{\mathrm{TM}}$ with the liquid, followed by slow mixing for $10 \mathrm{~min}$ at 80 r.p.m. to promote flocculation, followed $45 \mathrm{~min}$ agitators off to give way to the decantation.

\subsubsection{Particle Size Distribution}

The sludge analyzed was obtained from the AnMBR: biological reactor (S.p.1, S.p.7 and upper part of internal 3-phase separator (S.p.bell)) and filtration unit (S.p.6). In the 
corresponding tables are represented particle size distribution (\% number) from the sludge suspension from the different sampling points.

\subsubsection{Turbidity Metter}

Turbidity measurements were done with different concentrations of MPE50 ${ }^{\mathrm{TM}}$ with tap water to represent the effect of turbidity with different concentrations of polymer and the TMP with the increase of flux. Turbidity was measured with sludge from S.p.6 and $\mathrm{MPE} 50^{\mathrm{TM}}+$ tap water.

\subsubsection{Chemical Analysis Protocol}

Analyzes were carried out with the supernatant of the sampling points of the AnMBR. tCOD, sCOD, total solids, volatile solids, were determined according to the Standard methods for examination of water and wastewater (APHA., AWWA. and WPCF., 2005). sCOD was determined following sample filtration through $0.45 \mu \mathrm{m}$.

\subsection{Results and Discussion}

\subsubsection{Analysis of critical flux measurements}

Figure 5.3 (a), 5.4 (a), 5.5 (a) and 5.6 (a) presents a typical response curve, resulting from a stepwise flux increase during a critical flux measurement, in the diferents samples from the AnMBR. During the first stages of flux increase, TMP increments are linear (Fig. 5.3 (b), 5.4 (b), 5.5 (b) and 5.6 (b)). However, at a specific flux, the resulting TMP deviates from the linear correlation and increases to higher levels.

Fig. 5.3 (b), 5.4 (b), 5.5 (b) and 5.6 (b) also shows the pressure at the end of each filtration and back flush cycle, performed between each flux increase. It should be noted that the back flush TMP shows a linear correlation with the imposed flux, which means a constant resistance. A constant resistance during the back flush cycles, even over the critical flux, indicates that the pressure increase during the filtration period was mainly due to reversible phenomena. 

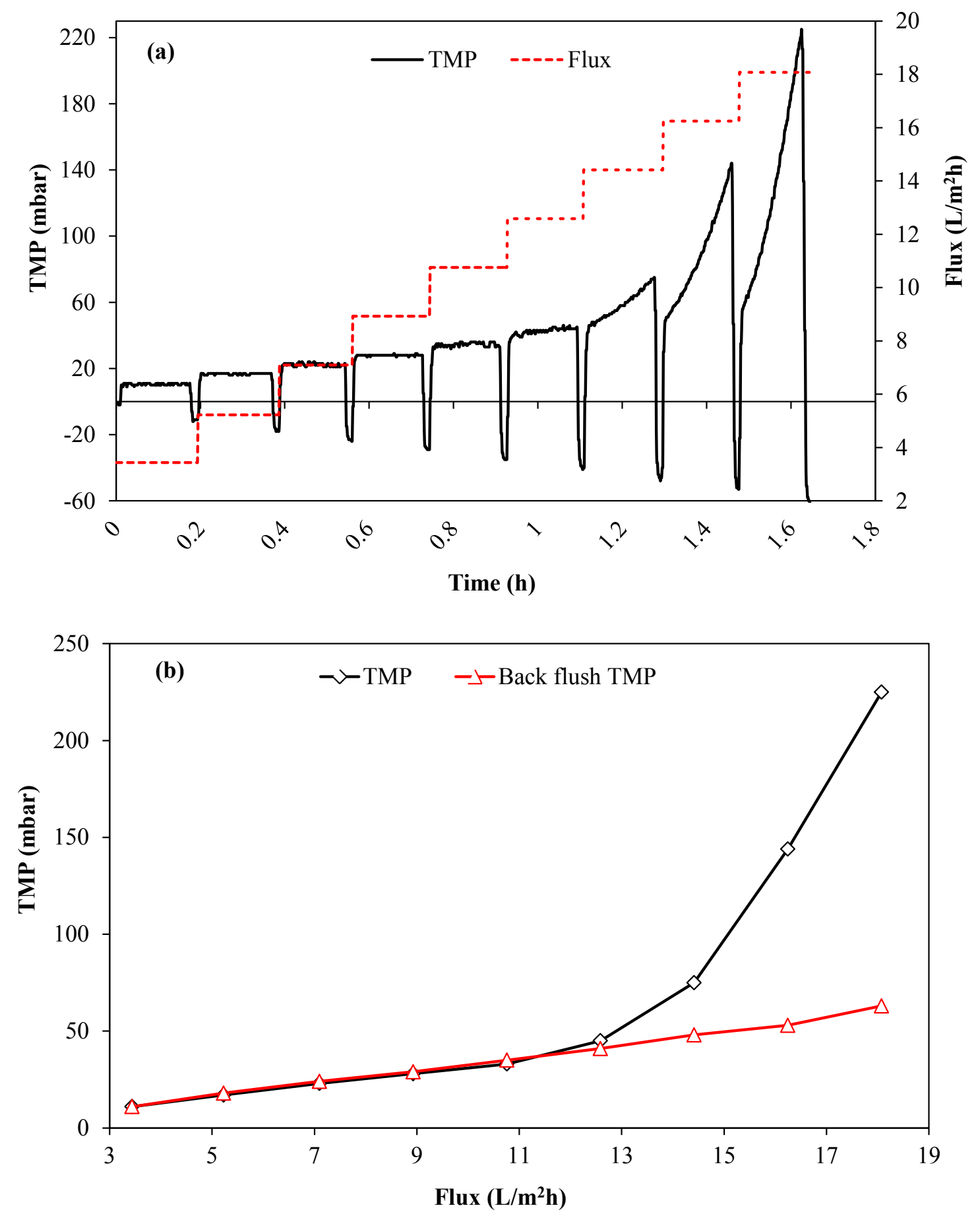

Figure 5.3. Critical flux measurement for the S.p.1: (a) stepwise flux increase and TMP response evolution, (b) TMP at end of each filtration and back flush period. Experimental conditions: biomass concentration, $13.81 \mathrm{~g}$ TS/L. 


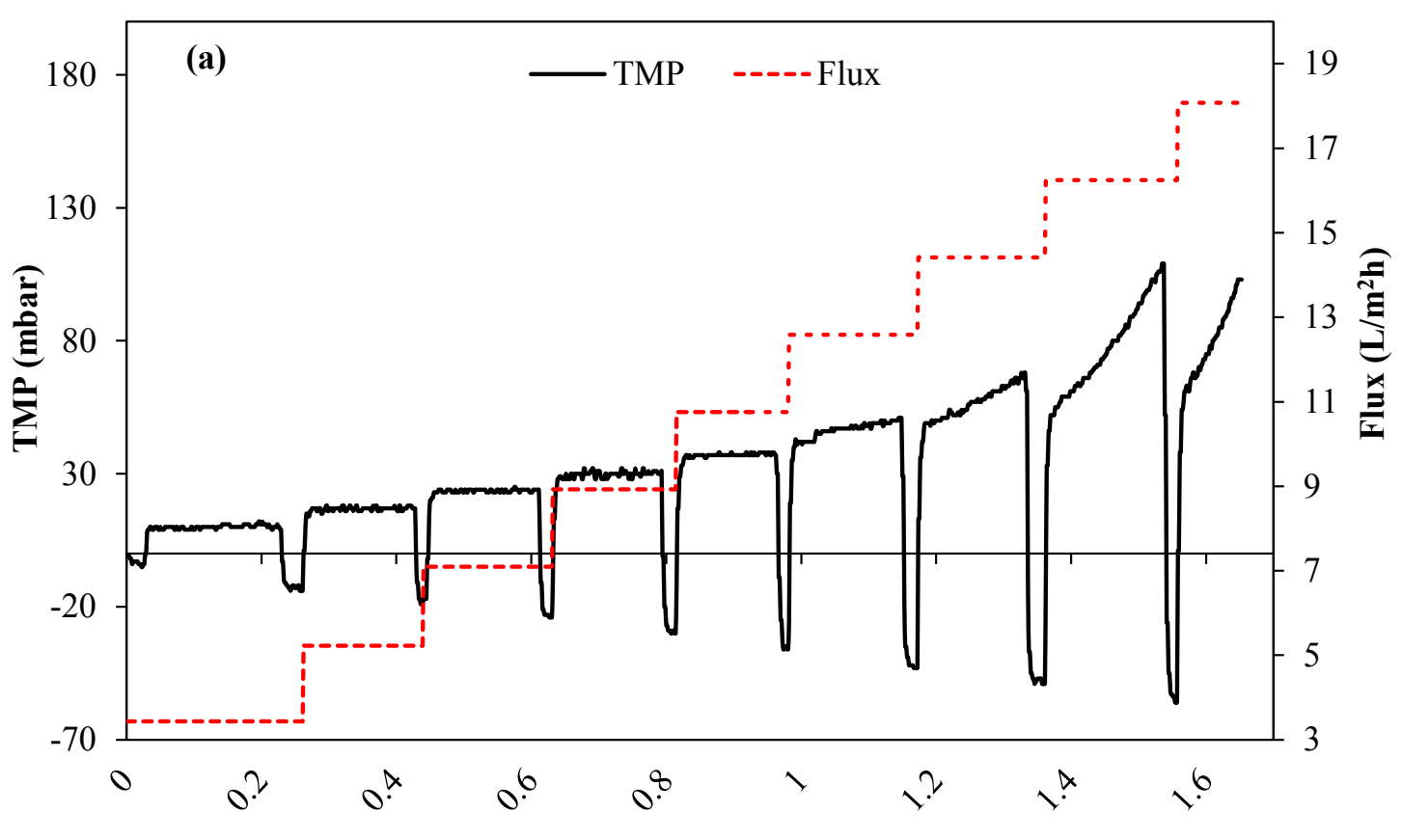

Time (h)

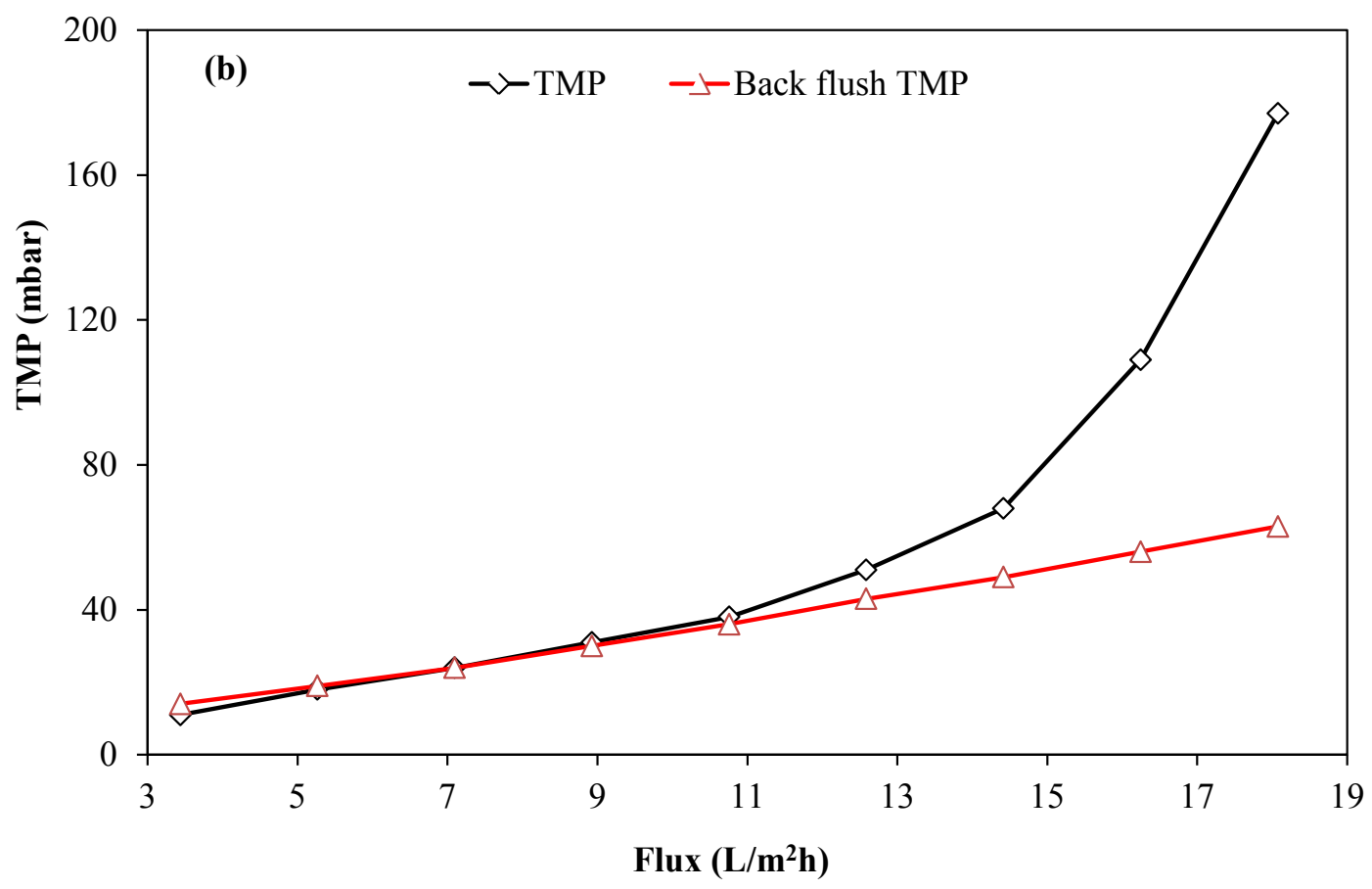

Figure 5.4. Critical flux measurement for the S.p.7: (a) stepwise flux increase and TMP response evolution, (b) TMP at end of each filtration and back flush period. Experimental conditions: biomass concentration, $10.03 \mathrm{~g} \mathrm{TS} / \mathrm{L}$. 


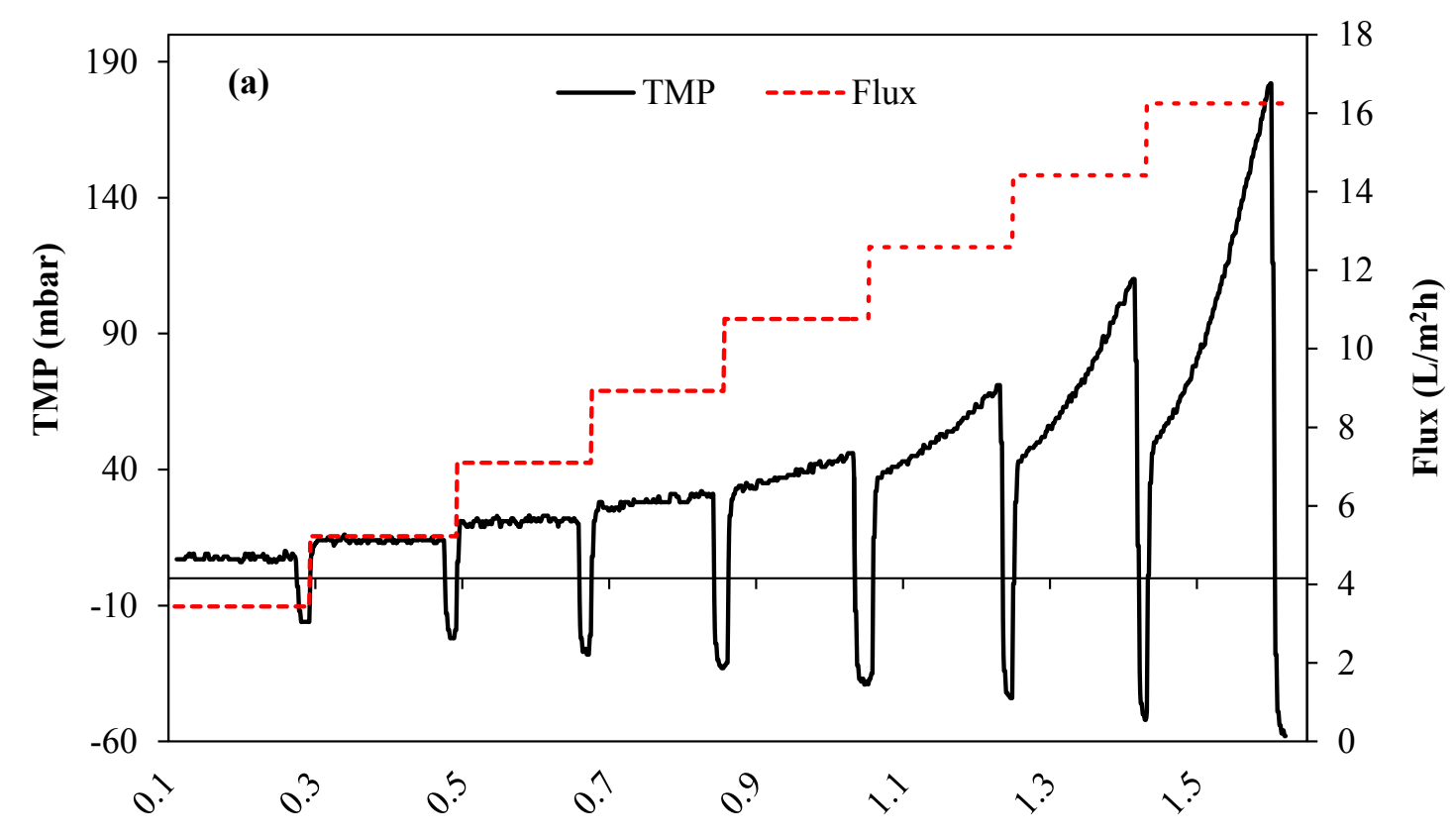

Time (h)

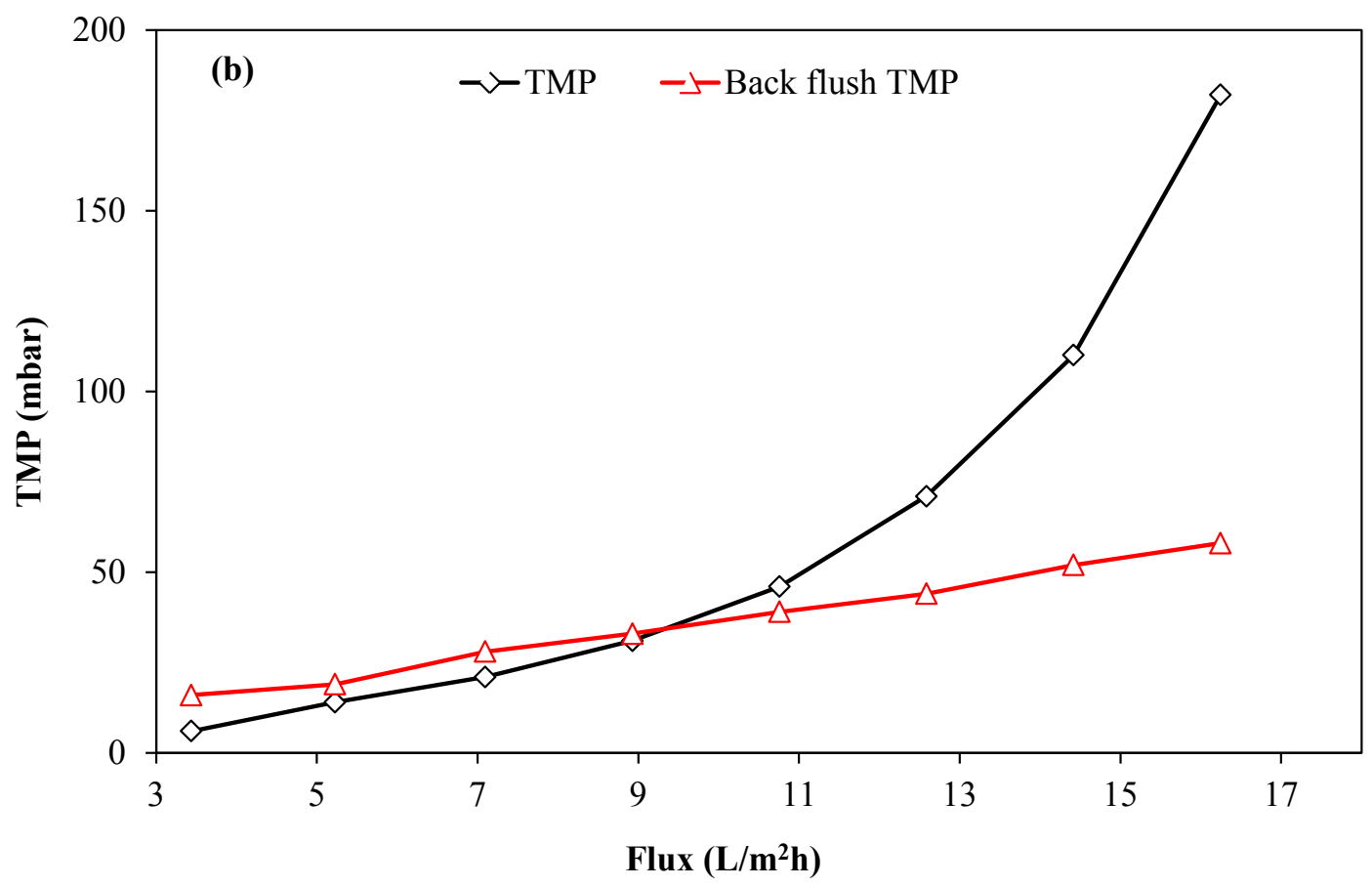

Figure 5.5. Critical flux measurement for the S.p.bell: (a) stepwise flux increase and TMP response evolution, (b) TMP at end of each filtration and back flush period. Experimental conditions: biomass concentration, $1.52 \mathrm{~g} \mathrm{TS} / \mathrm{L}$. 


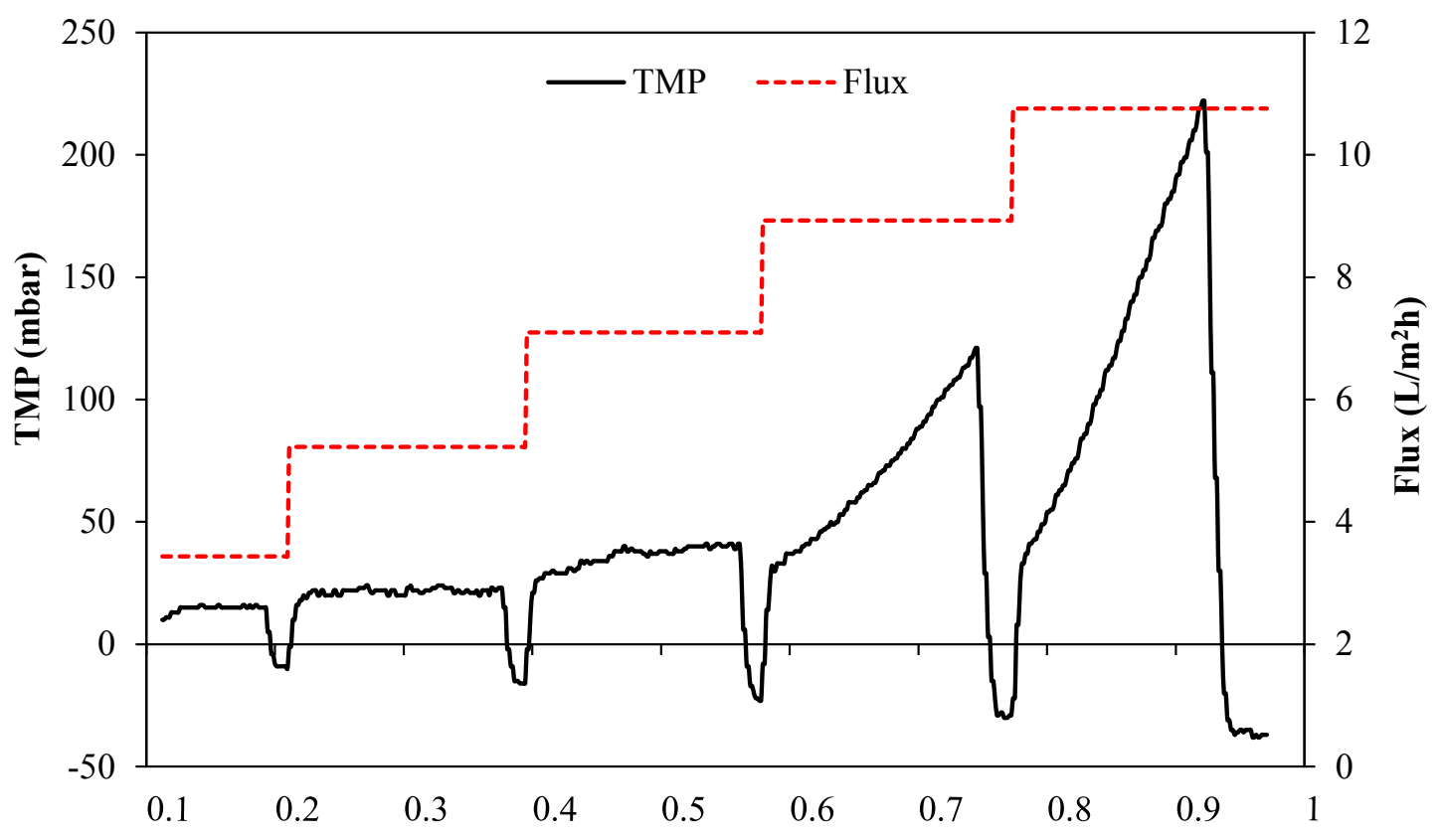

Time (h)

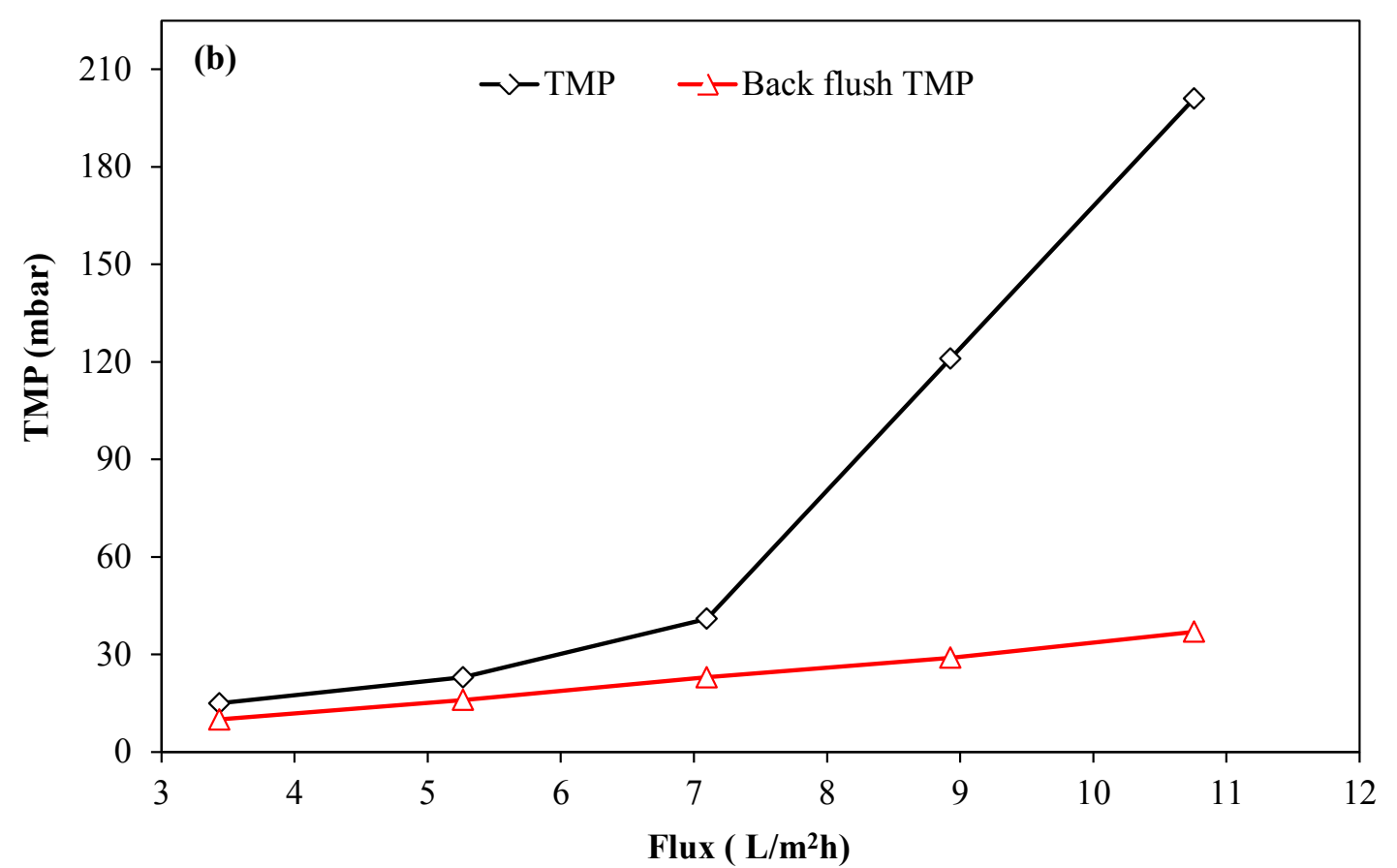

Figure 5.6. Critical flux measurement for the S.p.6: (a) stepwise flux increase and TMP response evolution, (b) TMP at end of each filtration and back flush period. Experimental conditions: biomass concentration, $12.80 \mathrm{~g} \mathrm{TS} / \mathrm{L}$. 
In the table 5.1 were summarized the critical flux in each sampling point of the AnMBR pilot plant on day 450 of operation, with gas superficial velocity of $0.035 \mathrm{~m} / \mathrm{h}$. The critical flux has been exceeded, due to the formation of a cake layer over the membrane surface.

Table 5.1. Critical flux of the AnMBR pilot plant on day 450.

\begin{tabular}{ccc}
\hline & TS (g/L) & Critical flux $\left(\mathbf{L} / \mathbf{m}^{2} \mathbf{h}\right)$ \\
\hline S.p.1 & 13.81 & 14.4 \\
S.p.7 & 10.03 & 14.4 \\
S.p.bell & 1.52 & 12.5 \\
S.p.6 & 12.80 & 7 \\
\hline
\end{tabular}

\subsubsection{Analysis of specific cake resistance}

\section{- Specific cake resistance on day 404}

In figure 5.7 was represented the experimental data with the suspension of the S.p.6, where is represented the slope that is used for calculating the specific cake resistance, being observed that increasing the flux, the slope increases leading to an increase in the specific cake resistance. To the others sampling points the experimental data are not shown.

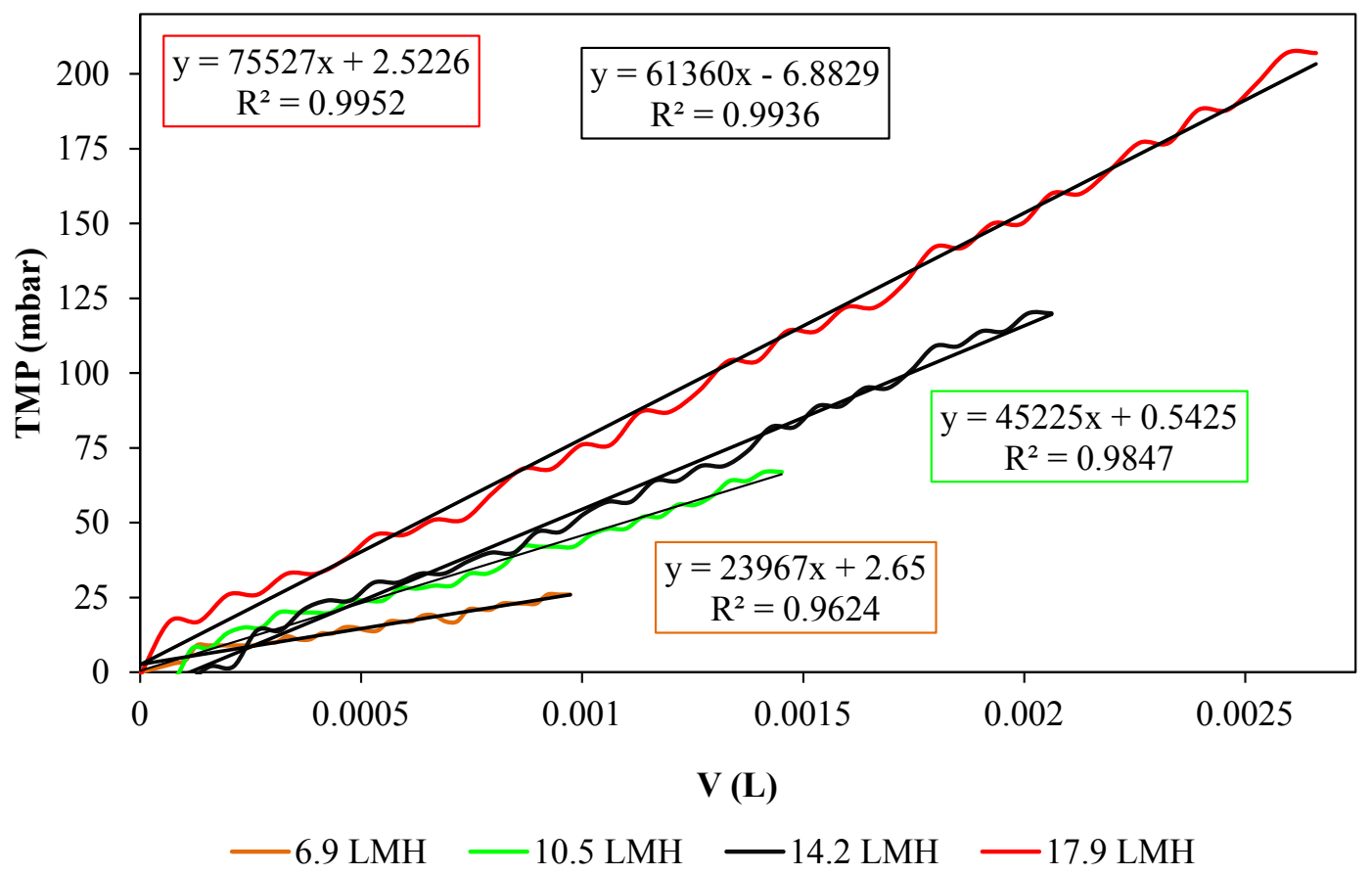

Figure 5.7. Experimental data of the S.p.6 on day $404(\mathrm{TS}=13.67 \mathrm{~g} / \mathrm{L})$. 
Using the equation 3 from section 5.1.1 the specific cake resistance was calculated from the different samplings points as a function of the flow rates.

Table 5.2 summarizes the different specific cake resistance obtained for differents sampling points on day 404. The results showed that in the S.p.1 and 7 the specific resistance is very similar, whereas in the S.p.bell increasing the flux, the specific resistance is also increased.

Table 5.2. Specific cake resistance of the bulk solution from the different S.p. of the AnMBR on day 404, without gas recirculation.

\begin{tabular}{ccccc}
\hline & \multicolumn{4}{c}{$\boldsymbol{\alpha}^{*} \mathbf{1 0}^{14}(\mathbf{m} / \mathbf{K g})$} \\
\hline Flux $\left(\mathbf{L} / \mathbf{m}^{2} \mathbf{h}\right)$ & S.p.1 & S.p.7 & S.p.bell & S.p.6 \\
$\mathbf{6 . 9}$ & 0.52 & 0.54 & 1.62 & 2.46 \\
$\mathbf{1 0 . 5}$ & 0.69 & 0.61 & 1.83 & 3.02 \\
$\mathbf{1 4 . 2}$ & 0.91 & 0.71 & 2.31 & 3.04 \\
$\mathbf{1 7 . 9}$ & 1.1 & 0.88 & 3.12 & 2.98 \\
$\mathbf{2 1 . 5}$ & 1.2 & 0.96 & 3.98 & n.a. \\
\hline
\end{tabular}

n.a. - not analysed

In the table 5.3 the particle size distribution (\% number) of the suspension from the different sampling points on day 404 was summarize. The sampling points 1,7 and 6 show us identical particle size distribution, because it is due to the hardly settleable particles.

Table 5.3. Particle size distribution from the different S.p. of the AnMBR on day 404 .

\begin{tabular}{cccc}
\hline S.p. & d (0.1) & d (0.5) & d (0.9) \\
\hline $\mathbf{1}$ & $0.457 \mu \mathrm{m}$ & $0.594 \mu \mathrm{m}$ & $1.064 \mu \mathrm{m}$ \\
$\mathbf{7}$ & $0.459 \mu \mathrm{m}$ & $0.597 \mu \mathrm{m}$ & $1.064 \mu \mathrm{m}$ \\
bell & $0.402 \mu \mathrm{m}$ & $0.551 \mu \mathrm{m}$ & $1.021 \mu \mathrm{m}$ \\
$\mathbf{6}$ & $0.454 \mu \mathrm{m}$ & $0.589 \mu \mathrm{m}$ & $1.067 \mu \mathrm{m}$ \\
\hline
\end{tabular}




\section{- Specific cake resistance filtered by $0.45 \mu \mathrm{m}$ on day 443}

In order to determine the effect of particle size distribution on the specific cake resistance, the suspension from differents sampling points is filtered with a filter of 0.45 $\mu \mathrm{m}$ (mean pore size). The specific cake resistance of the unfiltered sample (suspension) and after filtered by $0.45 \mu \mathrm{m}$ (Fig. 5.8) was determined.
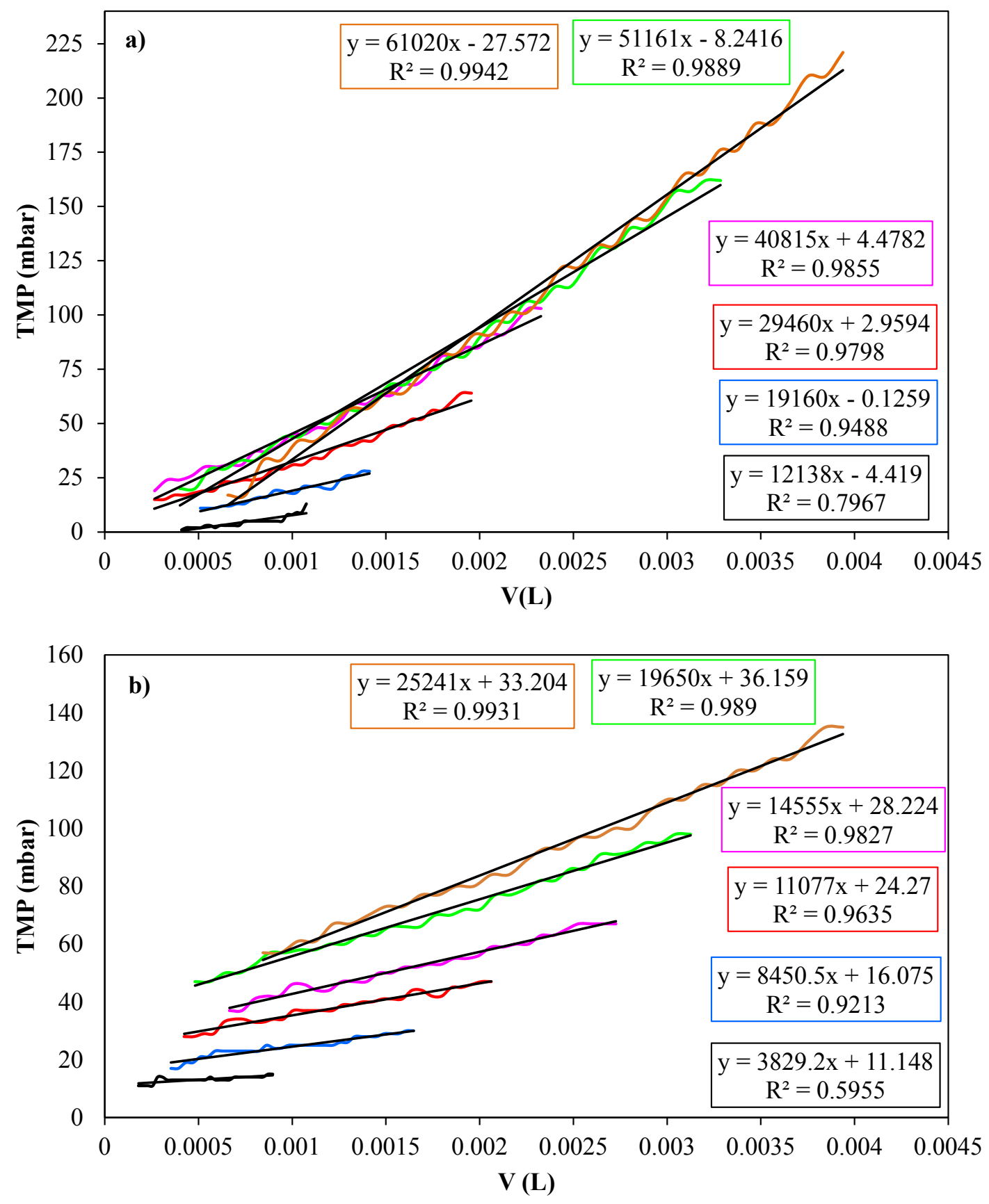

$-6.9 \mathrm{LMH}-10.5 \mathrm{LMH}-14.2 \mathrm{LMH}-17.9 \mathrm{LMH}-21.5 \mathrm{LMH}-25.2 \mathrm{LMH}$

Figure 5.8. Experimental data of from S.p.6. a) without filtering $(\mathrm{TS}=5.79 \mathrm{~g} / \mathrm{L}) \mathbf{b})$ filtered by $0.45 \mu \mathrm{m}(\mathrm{TS}=0.97 \mathrm{~g} / \mathrm{L})$. 
Table 5.4 summarizes the specific cake resistance of the suspension from the different sampling points, and the same suspension but filtered by $0.45 \mu \mathrm{m}$. Being filtered through $0.45 \mu \mathrm{m}$ was observed an increase in the specific cake resistance of the various sampling points. The solid concentration was measured before and after filtering by $0.45 \mu \mathrm{m}$.

From the same unfiltered and filtered suspension, the particle size distribution was measured and summarize in table 5.5. In the S.p.7, bell and 6 the effect of the previous filtration by $0.45 \mu \mathrm{m}$ were observed. The small particle sizes in the S.p.7, bell and 6 causing an increase in the specific cake resistance around $89.5 \pm 2.5 \%, 17.4 \pm 7.4 \%$ and $55.6 \pm 4.8 \%$, respectively. 
Table 5.4. Specific cake resistance of the bulk solution from diferents sampling points on day 443, without gas recirculation.

\begin{tabular}{|c|c|c|c|c|c|c|c|c|}
\hline \multirow[b]{3}{*}{ Flux $\left(L / m^{2} h\right)$} & \multicolumn{8}{|c|}{$\alpha^{*} 10^{14}(\mathrm{~m} / \mathrm{Kg})$} \\
\hline & \multicolumn{2}{|c|}{ S.p.1 } & \multicolumn{2}{|c|}{ S.p.7 } & \multicolumn{2}{|c|}{ S.p.bell } & \multicolumn{2}{|c|}{ S.p.6 } \\
\hline & $\begin{array}{l}\text { Without } \\
\text { filtering }\end{array}$ & $\begin{array}{c}\text { Filtering by } \\
0.45 \mu \mathrm{m}\end{array}$ & $\begin{array}{l}\text { Without } \\
\text { filtering }\end{array}$ & $\begin{array}{c}\text { Filtering by } \\
0.45 \mu \mathrm{m}\end{array}$ & $\begin{array}{l}\text { Without } \\
\text { filtering }\end{array}$ & $\begin{array}{c}\text { Filtering by } \\
0.45 \mu \mathrm{m}\end{array}$ & $\begin{array}{l}\text { Without } \\
\text { filtering }\end{array}$ & $\begin{array}{c}\text { Filtering by } \\
0.45 \mu \mathrm{m}\end{array}$ \\
\hline 6.9 & 0.26 & n.a. & 0.32 & 3.94 & 2.74 & 2.95 & 2.93 & 5.53 \\
\hline 10.5 & 0.46 & n.a. & 0.28 & 3.91 & 2.23 & 2.03 & 3.02 & 7.96 \\
\hline 14.2 & 0.51 & n.a. & 0.48 & 3.99 & 3.35 & 3.84 & 3.45 & 7.75 \\
\hline 17.9 & 0.58 & n.a. & 0.52 & 4.08 & 3.36 & 4.75 & 3.80 & 8.09 \\
\hline 21.5 & 0.67 & n.a. & 0.61 & 4.89 & 4.27 & 5.28 & 3.95 & 9.06 \\
\hline 25.2 & 0.74 & n.a. & 0.70 & 5.90 & 5.31 & 6.52 & 4.03 & 9.95 \\
\hline
\end{tabular}

n.a. - not analysed 
Table 5.5. Particle size distribution from the different S.p. of the AnMBR on day 443.

\begin{tabular}{lll}
\hline$d(0.1)$ & $d(0.5)$ & $d(0.9)$
\end{tabular}

\begin{tabular}{ccc|cc|cc}
\hline S.p. & $\begin{array}{c}\text { Without } \\
\text { filtering }\end{array}$ & $\begin{array}{c}\text { Filtering } \\
\text { by } \mathbf{0 . 4 5} \boldsymbol{\mu m}\end{array}$ & $\begin{array}{c}\text { Without } \\
\text { filtering }\end{array}$ & $\begin{array}{c}\text { Filtering } \\
\text { by } \mathbf{0 . 4 5} \boldsymbol{\mu m}\end{array}$ & $\begin{array}{c}\text { Without } \\
\text { filtering }\end{array}$ & $\begin{array}{c}\text { Filtering } \\
\text { by } \mathbf{0 . 4 5} \boldsymbol{\mu m}\end{array}$ \\
\hline $\mathbf{1}$ & $2.477 \mu \mathrm{m}$ & n.a. & $3.702 \mu \mathrm{m}$ & n.a. & $9.896 \mu \mathrm{m}$ & n.a. \\
$\mathbf{7}$ & $2.529 \mu \mathrm{m}$ & $0.190 \mu \mathrm{m}$ & $4.048 \mu \mathrm{m}$ & $0.256 \mu \mathrm{m}$ & $11.996 \mu \mathrm{m}$ & $0.449 \mu \mathrm{m}$ \\
bell & $1.849 \mu \mathrm{m}$ & $0.160 \mu \mathrm{m}$ & $2.673 \mu \mathrm{m}$ & $0.204 \mu \mathrm{m}$ & $5.209 \mu \mathrm{m}$ & $0.341 \mu \mathrm{m}$ \\
$\mathbf{6}$ & $2.138 \mu \mathrm{m}$ & $0.034 \mu \mathrm{m}$ & $3.108 \mu \mathrm{m}$ & $0.063 \mu \mathrm{m}$ & $6.953 \mu \mathrm{m}$ & $0.115 \mu \mathrm{m}$ \\
\hline n.a. - not analysed & & & & &
\end{tabular}

- Specific cake resistance on day 808

Figure 5.9 illustrates the experimental data with the suspension of the S.p.6, three months after a purge on membrane tank.

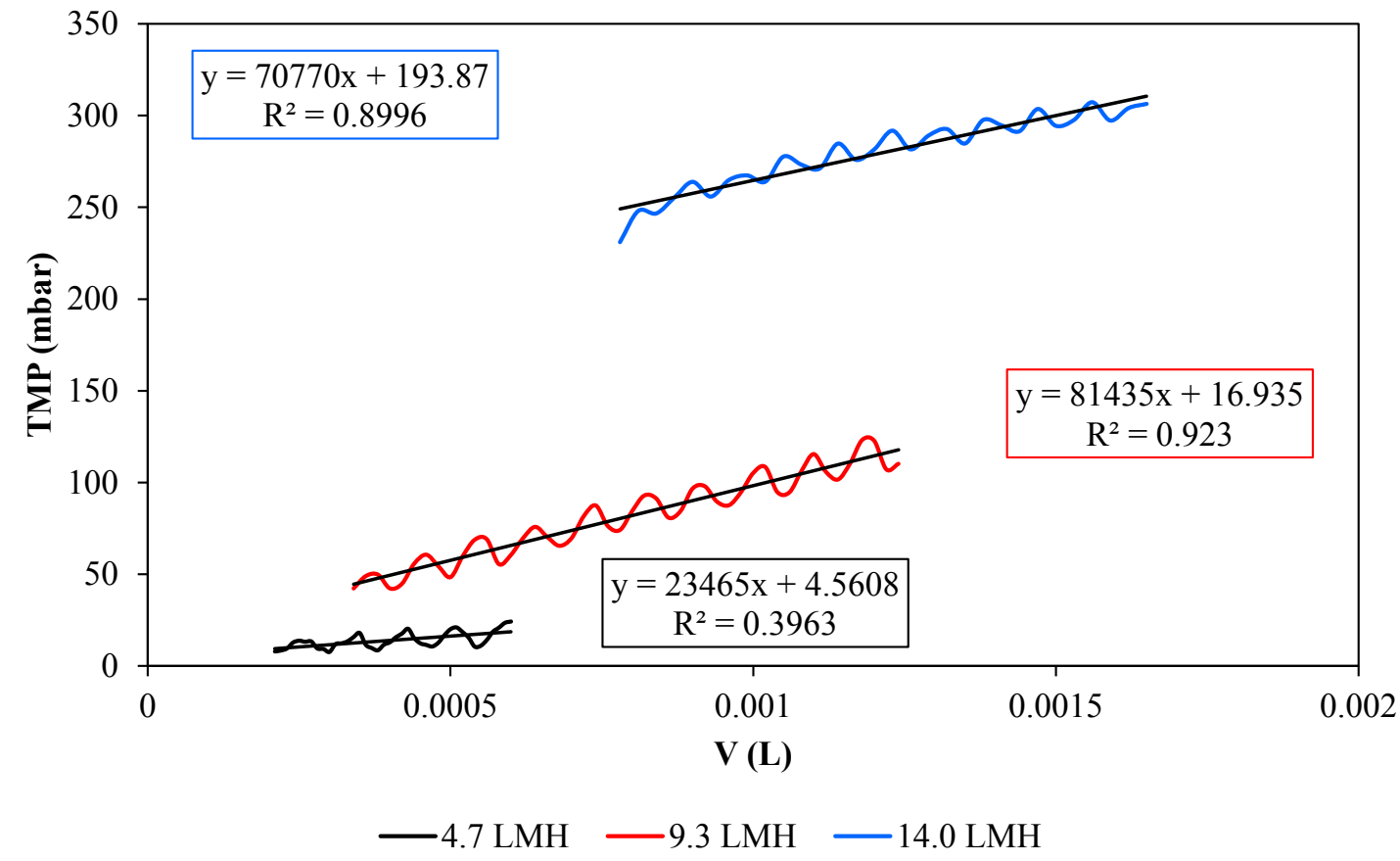

Figure 5.9. Experimental data of the S.p.6 on day $808(\mathrm{TS}=8.42 \mathrm{~g} / \mathrm{L})$.

Table 5.6 summarizes the values of the specific cake resistance of the differents sampling points of the pilot plant. The specific cake resistance in all the sampling points resistance increases significantly, due to the higher superficial velocity on the UASB 
and hardly settleable particles, and higher biogas sparging on membrane tank causing rupture of the biomass and to higher flux of $15 \mathrm{~L} / \mathrm{m}^{2} \mathrm{~h}$.

Table 5.6. Specific cake resistance of the bulk solution from the different S.p. of the AnMBR on day 808 , without gas recirculation.

\begin{tabular}{cccc}
\hline & \multicolumn{3}{c}{$\boldsymbol{\alpha}^{*} \mathbf{1 0}^{\mathbf{1 4}}(\mathbf{m} / \mathbf{K g})$} \\
\hline Flux (L/m $\left.{ }^{2} \mathbf{h}\right)$ & S.p.1 & S.p.bell & S.p.6 \\
$\mathbf{4 . 7}$ & 1.75 & 2.12 & 5.51 \\
$\mathbf{9 . 3}$ & 3.51 & 4.96 & 9.56 \\
$\mathbf{1 4 . 0}$ & 4.83 & 11 & 5.54 \\
\hline
\end{tabular}

\section{- Specific cake resistance on day 1082}

On day 1082, was collected a sample of the suspension from S.p.6 and was calculated experimentally the specific cake resistance, without gas recirculation (Fig. 5.10). Three experiments are made with the bulk solution, the supernatant after three and eight hours after decanting, to ensure that the largest particles have been removed. Increasing the time of sedimentation in the suspension, remaining only remain the particles hardly settleable. 

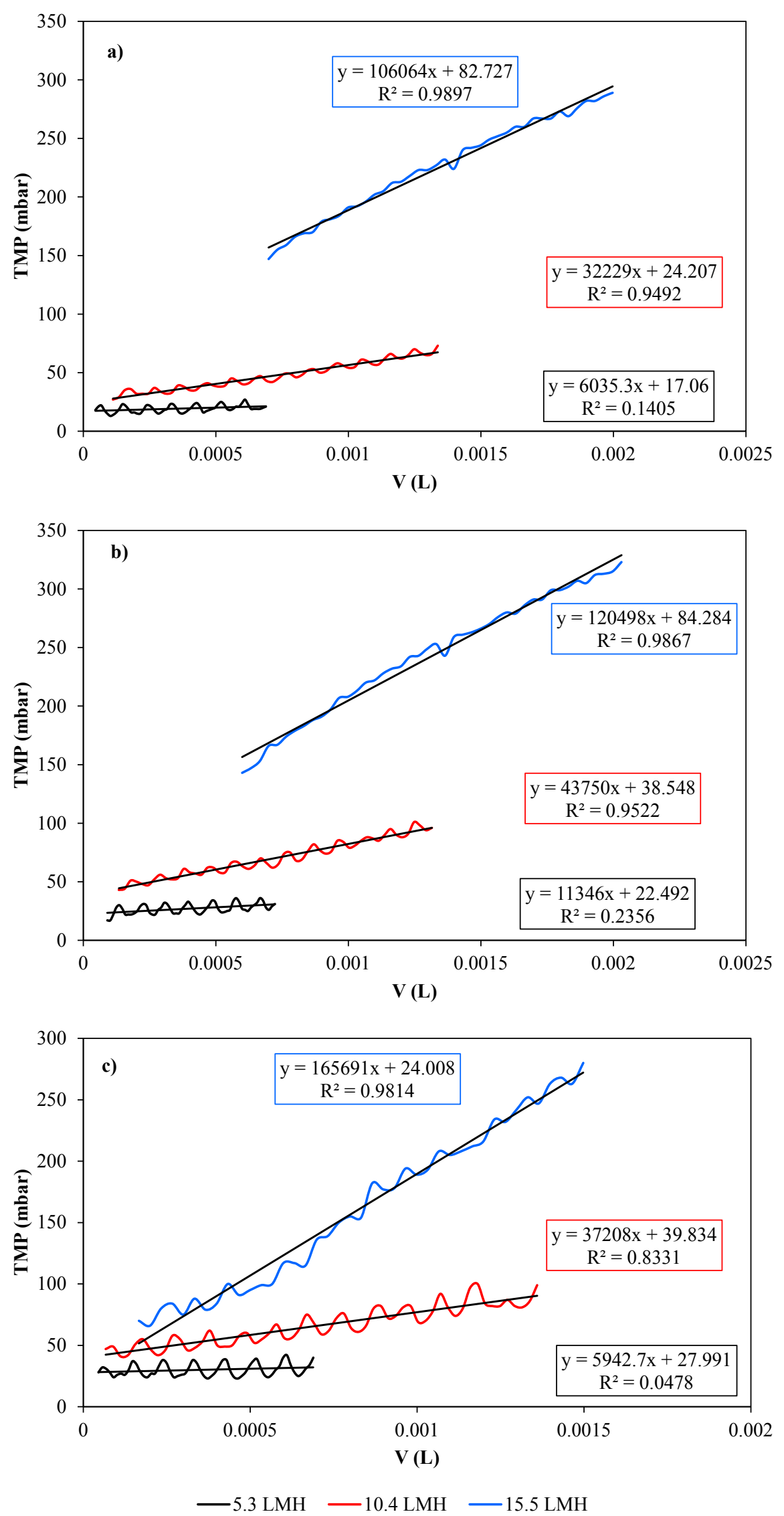

Figure 5.10. Experimental data of the S.p. 6 on day 1082 a) bulk solution (TS $=6.69$ $\mathrm{g} / \mathrm{L})$ b) $3 \mathrm{~h}$ decanted $(\mathrm{TS}=4.65 \mathrm{~g} / \mathrm{L})$ c) $8 \mathrm{~h}$ decanted $(\mathrm{TS}=3.78 \mathrm{~g} / \mathrm{L})$. 
Table 5.7. Specific cake resistance of the bulk solution from S.p.6 of the AnMBR on day 1082, without gas recirculation.

\begin{tabular}{cccc}
\hline & \multicolumn{3}{c}{$\boldsymbol{\alpha}^{*} \mathbf{1 0}^{\mathbf{1 4}}(\mathbf{m} / \mathbf{K g})$} \\
\hline Flux (L/m $\left.\mathbf{m}^{\mathbf{h}}\right)$ & S.p.6 & 3h decanted & 8h decanted \\
$\mathbf{5 . 2}$ & 1.58 & 4.27 & 2.75 \\
$\mathbf{1 0 . 4}$ & 4.27 & 8.35 & 8.73 \\
$\mathbf{1 5 . 5}$ & 9.42 & 15.4 & 26 \\
\hline
\end{tabular}

According with the Table 5.8, the particle size before and after the experiment are almost equal, occurring a small decrease in the size, which means that the increase in the specific cake resistance is due to the increase of the flux and the particle size (Table $5.8)$.

Table 5.8. Particle size distribution from the S.p.6 of the AnMBR on day 1082.

\begin{tabular}{cccc}
\hline S.p. & $\mathbf{d}(\mathbf{0 . 1})$ & $\mathbf{d}(\mathbf{0 . 5})$ & $\mathbf{d}(\mathbf{0 . 9})$ \\
\hline bulk solution & $0.539 \mu \mathrm{m}$ & $0.721 \mu \mathrm{m}$ & $1.551 \mu \mathrm{m}$ \\
3h decanted & $0.532 \mu \mathrm{m}$ & $0.701 \mu \mathrm{m}$ & $1.399 \mu \mathrm{m}$ \\
8h decanted & $0.529 \mu \mathrm{m}$ & $0.690 \mu \mathrm{m}$ & $1.339 \mu \mathrm{m}$ \\
\hline
\end{tabular}

Working with flux of $5 \mathrm{~L} / \mathrm{m}^{2} \mathrm{~h}$, after decanting 3 and 8 hours, the specific cake resistances are practically the same, increasing in 63 and $68.2 \%$, respectively. The same behavior occurs with a flux of $10 \mathrm{~L} / \mathrm{m}^{2} \mathrm{~h}$, resulting in an increase of 48.9 and $51.1 \%$, respectively. 


\section{- Specific cake resistance on day 1266}

Just a few days after doing a purge, the fig. 5.11 illustrates the experimental specific cake resistance on day 1266.

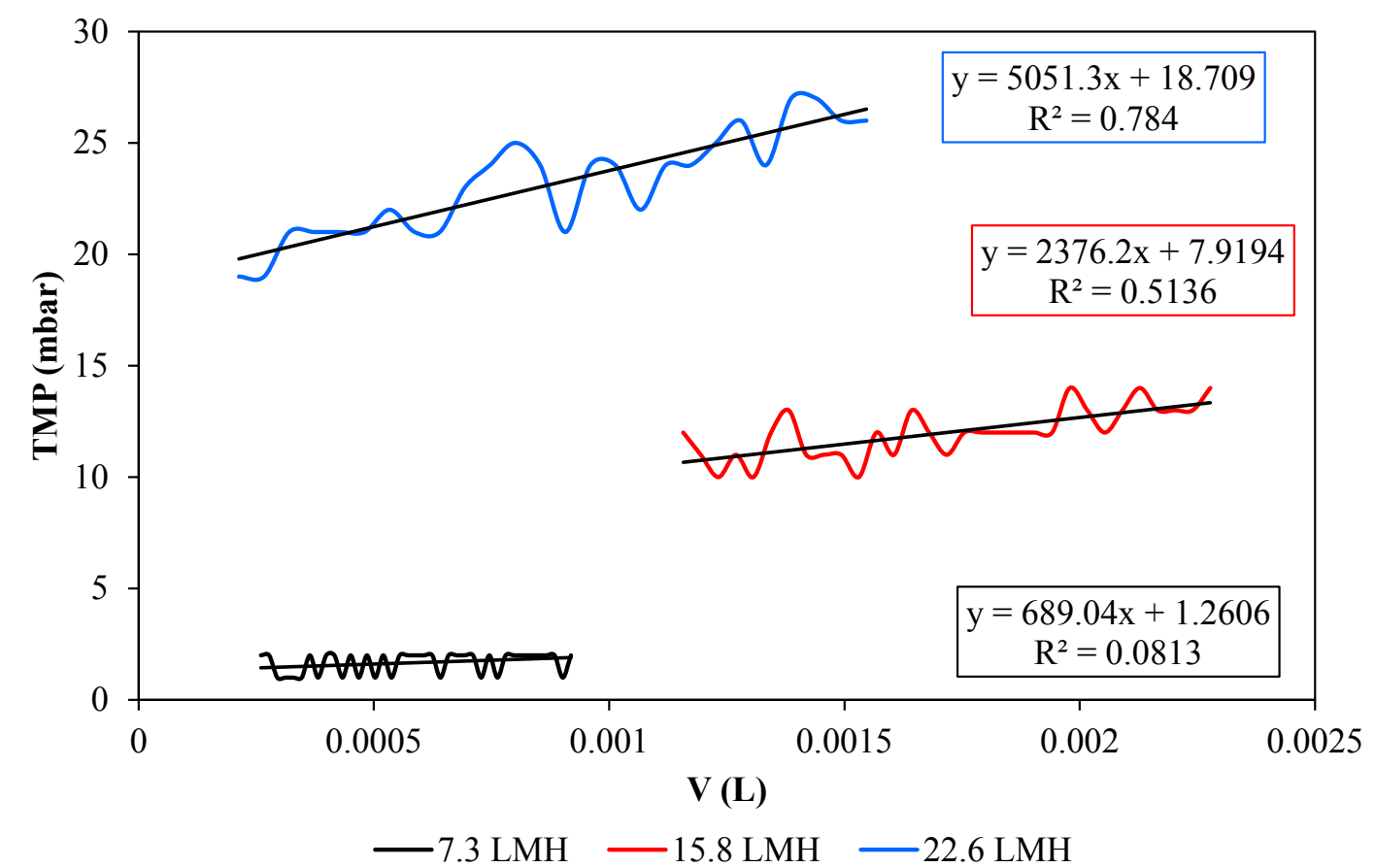

Figure 5.11. Experimental data of the S.p.6 on day $1266(\mathrm{TS}=5.91 \mathrm{~g} / \mathrm{L})$.

Table 5.9 summarizes the specific cake resistance with the increase of the flux. Working with higher fluxes and without gas recirculation, the specific cake resistance in the S.p.7 and 6, remain constant, meanwhile in the S.p.bell suffers a sudden increase in the specific cake resistance. Even though it the concentration of TS on S.p.bell and S.p.6 are diferent, the specific resistance it's higher in the S.p.bell, due to the hardly settleable particles. In the S.p.6 the higher TS concentration is due to the agitation, rupture and accumulation of the biomass. 
Table 5.9. Specific cake resistance of the bulk solution from the different S.p. of the AnMBR on day 1266, without gas recirculation.

\begin{tabular}{cccc}
\hline & \multicolumn{3}{c}{$\boldsymbol{\alpha}^{*} \mathbf{1 0}^{14}(\mathbf{m} / \mathbf{K g})$} \\
\hline Flux $\left(\mathbf{L} / \mathbf{m}^{2} \mathbf{h}\right)$ & S.p.7 & S.p.bell & S.p.6 \\
$\mathbf{7 . 3}$ & 0.18 & 0.37 & 0.16 \\
$\mathbf{1 5 . 8}$ & 0.23 & 0.43 & 0.26 \\
$\mathbf{2 2 . 5}$ & 0.24 & 0.51 & 0.38 \\
\hline
\end{tabular}

Considering a flux between $10-12 \mathrm{~L} / \mathrm{m}^{2} \mathrm{~h}$, average flux operation of the membrane module, table 5.10 summarize the evolution of the specific cake resistance during the tests.

Table 5.10. Specific cake resistance of the sludge from different sampling points with a flux between $10-12 \mathrm{~L} / \mathrm{m}^{2} \mathrm{~h}$.

\begin{tabular}{ccccc}
\hline & \multicolumn{4}{c}{$\boldsymbol{\alpha}^{*} \mathbf{1 0}^{\mathbf{1 4}}(\mathbf{m} / \mathbf{K g})$} \\
\hline $\mathbf{4 0 4}$ & S.p.1 & S.p.7 & S.p.bell & S.p.6 \\
$\mathbf{4 4 3}$ & 0.69 & 0.61 & 1.83 & 3.02 \\
$\mathbf{1 0 8 2}$ & 0.46 & 0.28 & 2.23 & 3.02 \\
& n.a. & n.a. & n.a. & 4.27 \\
\hline
\end{tabular}

n.a.- not analysed

As described earlier, specific cake resistance remains constant during the most part of operation of the AnMBR between $3-4.5^{*} 10^{14} \mathrm{~m} / \mathrm{Kg}$, except on day 808 that increases to $9.56 * 10^{14} \mathrm{~m} / \mathrm{Kg}$. In the day 1266 , the specific cake resistance remains low between $0.16-0.26^{*} 10^{14} \mathrm{~m} / \mathrm{Kg}$, with a high total solids concentration, having done a purge few days before. 


\subsubsection{Adsorbent/flux enhancers at lab-scale}

The experiences were made in order to determine if the addition of MPE50 ${ }^{\mathrm{TM}}$ improves the specific cake resistance, the experience was divid into two steps and to observe the effect of the polymer was analyzed turbidity and TMP.

1. Only with tap water at $18 \pm 2^{\circ} \mathrm{C}$ and $\mathrm{MPE} 50^{\mathrm{TM}}$ to determine if the TMP is affected.

2. Assays were performed with diferent concentrations of $\mathrm{MPE} 50^{\mathrm{TM}}$ to determine the optimum concentration, and then calculate the specific cake resistance with the supernatant.

Table 5.11 summarize the effect of turbidity with different concentrations of polymer and were observed the increasing in turbidity when the polymer concentration was increased.

Table 5.11. Turbidity measurements (mean values) with different concentrations of MPE50 ${ }^{\mathrm{TM}}$ with tap water.

\begin{tabular}{cc}
\hline MPE50 $^{\text {TM }}(\mathbf{p p m})$ & Turbidity (NTU) \\
\hline 0 & $0.027 \pm 0.005$ \\
50 & $0.033 \pm 0.005$ \\
100 & $0.087 \pm 0.005$ \\
200 & $0.547 \pm 0.031$ \\
\hline
\end{tabular}

In the fig. 5.12 was represented the evolution of TMP with the flux, were observed the influence of the polymer concentration in the increase of the TMP. 


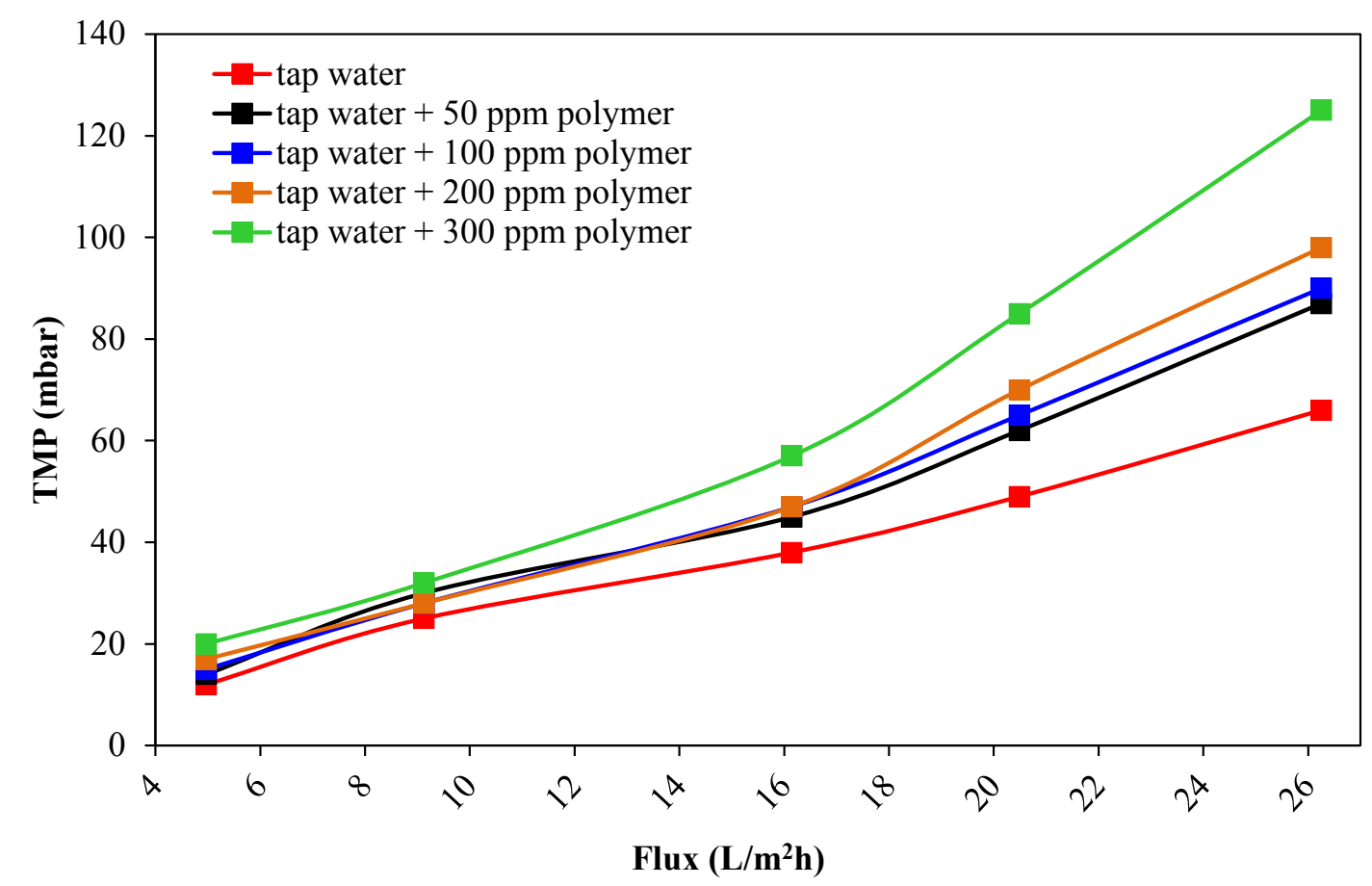

Figure 5.12. Evolution of TMP with different dosages of polymer + tap water.

In the second step, the experiences with the bulk suspension from S.p.6 were carried out with the supernatant after the polymer was added and no change in $\mathrm{pH}$ was observed. The bulk suspension from S.p. 6 for this assay was a tCOD $=3663 \mathrm{mg} / \mathrm{L}, \mathrm{sCOD}=398$ $\mathrm{mg} / \mathrm{L}, \mathrm{TS}=1.65 \mathrm{~g} / \mathrm{L}$ and $\mathrm{VS}=1.03 \mathrm{~g} / \mathrm{L}$.

The bulk suspension was an initial turbidity of 3320 NTU, a value very higher, when compared with the addition of the polymer achieving an optimal concentration between 600-650 ppm, reaching turbidity of 36 NTU (Fig.5.13). Collins et al., (2006), working with sludge from a pilot MBR at western US municipality with a MLSS around $10000-11000 \mathrm{mg} / \mathrm{L}$ and a range of temperature between $16-22^{\circ} \mathrm{C}$, reached the optimal dosage of $600 \mathrm{mg} / \mathrm{L}$ MPE50 ${ }^{\mathrm{TM}}$. 


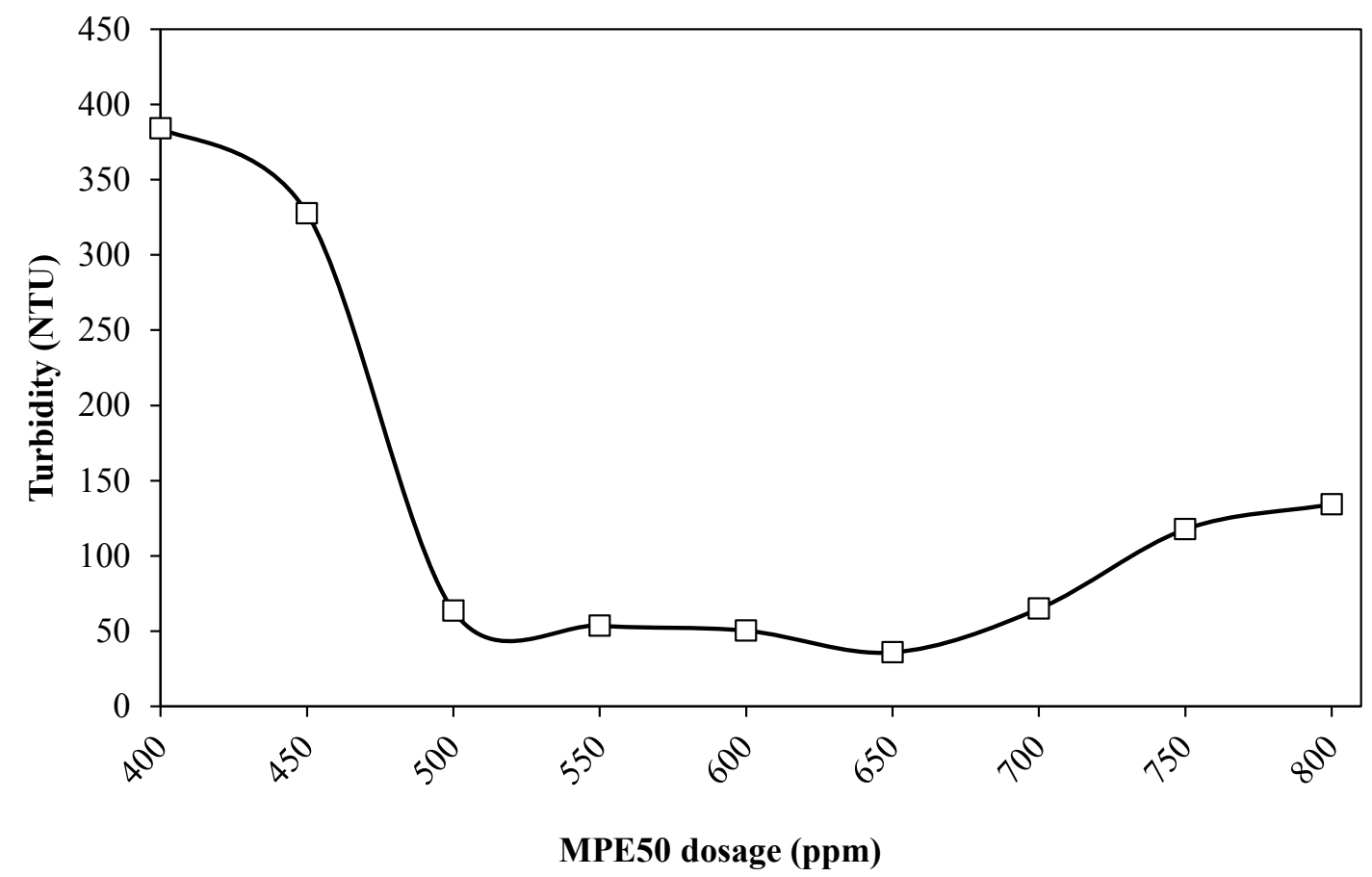

Figure 5.13. Turbidity of the supernatant of the bulk suspension from S.p.6 after 45 min of sedimentation with addition of MPE50 $0^{\mathrm{TM}}$.

The turbidity removal was quantified as the percentage of turbidity reduction with the control as the reference for comparison, according to following equation:

Turbidity removal $(\%)=\frac{\mathrm{NTU}_{\text {control }}-\mathrm{NTU}_{\text {sample }}}{\mathrm{NTU}_{\text {control }}}$

where $\mathrm{NTU}_{\text {control }}$ is the turbidity of the bulk suspension, $\mathrm{NTU}_{\text {sample }}$ is the turbidity of the sample with the polymer.

Calculated as such, the turbidity removal indicates the extent of the interaction (flocculation and/or adsorption) between the flocculants and the sludge (and other wastewater particles). The stronger interaction leads to more turbidity reduction, i.e., a larger difference $\left(\mathrm{NTU}_{\text {Control }}-\mathrm{NTU}_{\text {Sample }}\right)$ and a larger value of the flocculation activity (Qiu, 2005). 
The increase in the concentration of the MPE $50^{\mathrm{TM}}$ demonstrated very good ability to reducing the turbidity of the supernatant.

With concentrations between 600-650 ppm, the MPE50 ${ }^{\mathrm{TM}}$ have the ability to reduce the turbidity of the supernatant, was reached a turbidity removal around 98.5-98.9\% (Fig. 5.14).

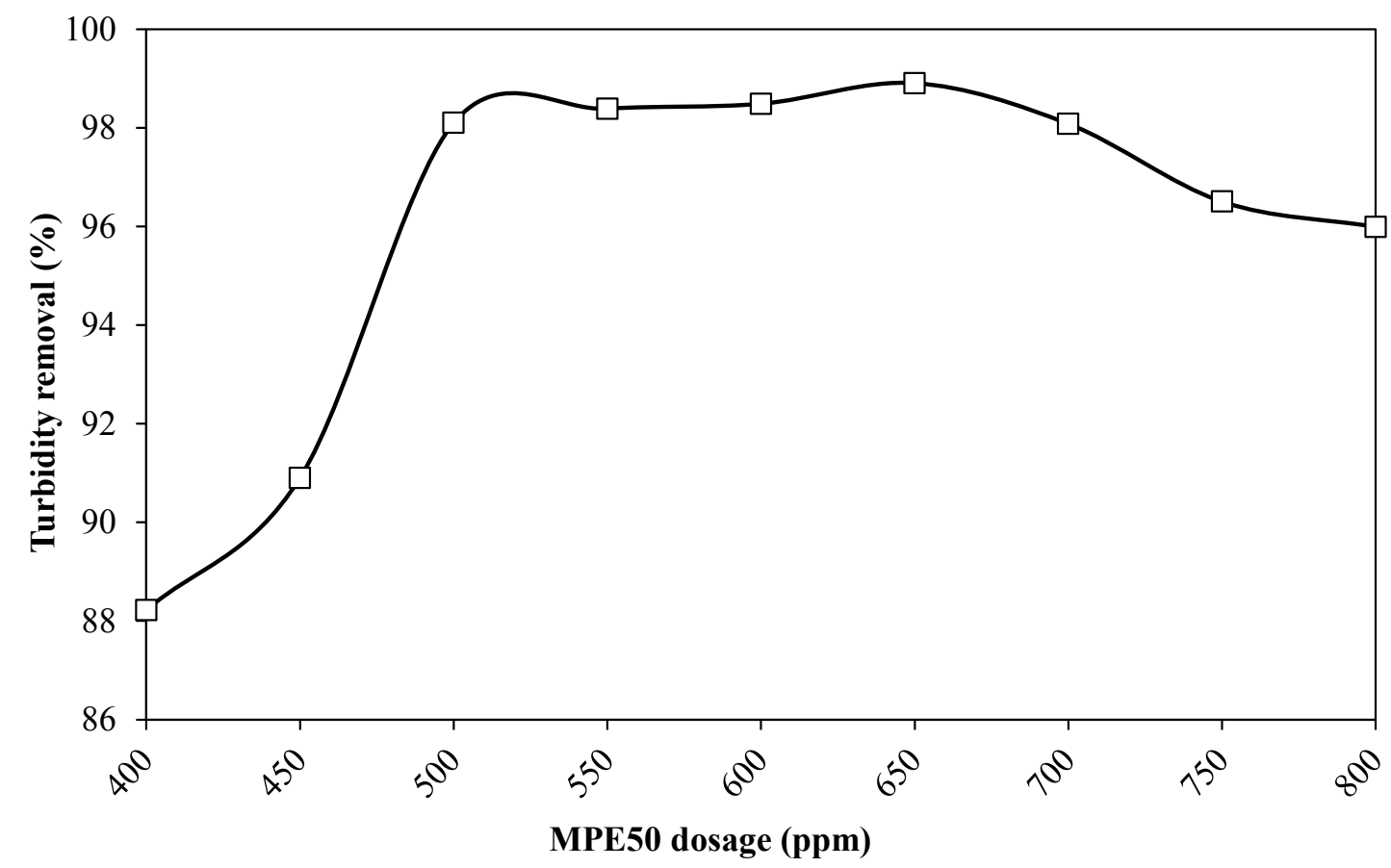

Figure 5.14. Percentage removal of turbidity to different dosages of polymer from the S.p.6.

Table 5.12 summarizes the physical-chemical analyses (tCOD, sCOD, TS and VS) from the bulk suspension before adding MPE $50^{\mathrm{TM}}$, permeate of the bulk suspension and from the supernatant with different MPE50 ${ }^{\mathrm{TM}}$ dosages. A significant decrease in tCOD on the bulk suspension with different dosages of MPE50 ${ }^{\mathrm{TM}}$ was observed, reaching an optimum dosage of $650 \mathrm{ppm}$ with a $\mathrm{tCOD}_{\text {removal }}$ of $96.92 \%$, and a removal of TS and VS of 49.8 and $61.7 \%$, respectively. 
Table 5.12. Evolution of tCOD removal efficiency with different dosages of MPE $50^{\mathrm{TM}}$ with the supernatant.

\begin{tabular}{|c|c|c|c|c|c|}
\hline $\begin{array}{c}\text { MPE50 }^{\mathrm{TM}} \text { dosage } \\
(\mathrm{ppm})\end{array}$ & $\begin{array}{l}\text { tCOD } \\
(\mathrm{mg} / \mathrm{L})\end{array}$ & $\begin{array}{l}\text { sCOD } \\
(\mathrm{mg} / \mathrm{L})\end{array}$ & $\begin{array}{c}\text { TS } \\
(\mathrm{g} / \mathrm{L})\end{array}$ & $\begin{array}{c}\mathrm{VS} \\
(\mathrm{g} / \mathrm{L})\end{array}$ & $\begin{array}{c}\text { tCOD removal } \\
(\%)\end{array}$ \\
\hline Bulk solution & 3663 & 398 & 1.65 & 1.03 & - \\
\hline Permeate* & 75 & n.a. & 0.70 & 0.33 & 97.95 \\
\hline 400 & 130 & 97 & 0.86 & 0.38 & 96.45 \\
\hline 450 & 123 & 90 & 0.84 & 0.36 & 96.64 \\
\hline 500 & 108 & 81 & 0.64 & 0.22 & 97.05 \\
\hline 550 & 114 & 88 & 0.68 & 0.47 & 96.89 \\
\hline 600 & 114 & 86 & 0.62 & 0.37 & 96.89 \\
\hline 650 & 113 & 87 & 0.83 & 0.39 & 96.92 \\
\hline
\end{tabular}

*_ filtered with the fiber (pore size $0.04 \mu \mathrm{m}$ ) $\quad$ n.a. - not analysed

Table 5.13 summarizes the permeate supernatant filtered with the fiber, and was observed that the tCOD, TS and VS with different doses of polymer concentration were very similar to permeate without polymer.

Table 5.13. Evolution of tCOD with different dosages of MPE50 ${ }^{\mathrm{TM}}$ with the supernatant filtered with the fiber.

\begin{tabular}{ccccc}
\hline $\begin{array}{c}\text { MPE50 } \\
(\mathbf{p p m})\end{array}$ & $\begin{array}{c}\text { TCOD } \\
(\mathbf{m g} / \mathbf{L})\end{array}$ & $\begin{array}{c}\text { SCOD } \\
(\mathbf{m g} / \mathbf{L})\end{array}$ & $\begin{array}{c}\text { TS } \\
(\mathbf{g} / \mathbf{L})\end{array}$ & $\begin{array}{c}\text { VS } \\
(\mathbf{g} / \mathbf{L})\end{array}$ \\
\hline Bulk solution & 3663 & 398 & 1.65 & 1.03 \\
Permeate* & 75 & n.a. & 0.70 & 0.33 \\
$\mathbf{5 0 0 * *}$ & 56 & n.a. & 0.60 & 0.19 \\
$\mathbf{5 5 0 * *}$ & 72 & n.a. & 0.76 & 0.40 \\
$\mathbf{6 0 0}^{* * *}$ & 66 & n.a. & 0.56 & 0.15 \\
$\mathbf{6 5 0}^{* * *}$ & 75 & n.a. & 0.95 & 0.49 \\
\hline
\end{tabular}

$*_{-}$filtered with the fiber (pore size $0.04 \mu \mathrm{m}$ ) $\quad * *_{-}$supernatant filtered with the fiber (pore size $0.04 \mu \mathrm{m}$ ) n.a. - not analysed 


\subsubsection{Specific cake resistance with addition of polymer}

Using the equation 3 from section 5.1., the specific cake resistance of the supernatant for different dosages of polymer during the corresponding period was calculated. The bulk suspension from S.p.6 for this assay was a TS=5.79 g/L and VS=3.85 g/L.

Table 5.14 summarizes the specific cake resistance obtained for differents dosages of polymer. In the bulk solution without polymer, the specific cake resistance remains constant, even increasing the flux. On the other hand, with the addition of polymer in the bulk solution, the increase of the specific cake resistance was observed.

Adding $400 \mathrm{ppm}$ of polymer without aire recirculation, the specific cake resistance decreased from 142 to $38.6^{*} 10^{14} \mathrm{~m} / \mathrm{Kg}$, varying the flux between $3-10 \mathrm{~L} / \mathrm{m}^{2} \mathrm{~h}$. Immediately, the same dosage of polymer with aire recirculation of $1.21 \mathrm{~m} / \mathrm{h}$ was added, and a decrease on the specific cake resistance with a flux of $6 \mathrm{~L} / \mathrm{m}^{2} \mathrm{~h}$ was observed.

Table 5.14. Specific cake resistance of the bulk suspension from S.p. 6 with different dosages of polymer on day 525 .

$$
\alpha^{*} 10^{14}(\mathrm{~m} / \mathrm{Kg})
$$

\begin{tabular}{|c|c|c|c|c|c|}
\hline MPE50 $^{\mathrm{TM}}$ dosage $(\mathrm{ppm})$ & \multirow[t]{2}{*}{ Bulk solution } & \multirow[t]{2}{*}{200} & \multirow[t]{2}{*}{400} & \multirow[t]{2}{*}{$400+$ aire } & \multirow[t]{2}{*}{800} \\
\hline Flux $\left(\mathrm{L} / \mathrm{m}^{2} \mathrm{~h}\right.$ & & & & & \\
\hline 3.1 & n.a. & 73.8 & 142 & 162 & 138 \\
\hline 6.6 & 2.93 & 25.7 & 50.7 & 37 & 48.6 \\
\hline 10.2 & 3.02 & 22.2 & 38.6 & 36.5 & n.a. \\
\hline 13.7 & 3.45 & n.a. & n.a. & n.a. & n.a. \\
\hline 17.8 & 3.80 & n.a. & n.a. & n.a. & n.a \\
\hline 21.5 & 3.95 & n.a & n.a & n.a & n.a \\
\hline 25.2 & 4.03 & n.a & n.a & n.a & n.a \\
\hline
\end{tabular}

n.a. - not analysed 
Table 5.15 summarizes the specific resistance done with lowest dosages of polymer. The bulk solution from S.p.6 for this assay was a TS=1.94 g/L and VS=0.43 g/L. The behavior for the bulk solution on day 544 was much higher than for the day 525 , due to the low TS concentration in the bulk solution.

Table 5.15. Specific cake resistance of the bulk solution from S.p. 6 with different dosages of polymer on day 544 .

\begin{tabular}{|c|c|c|c|c|}
\hline \multicolumn{5}{|c|}{$\alpha^{*} 10^{14}(\mathrm{~m} / \mathrm{Kg})$} \\
\hline MPE50 $^{\mathrm{TM}}$ dosage (ppm) & \multirow[t]{2}{*}{ Bulk solution } & \multirow[t]{2}{*}{200} & \multirow[t]{2}{*}{250} & \multirow[t]{2}{*}{300} \\
\hline Flux $\left(\mathrm{L} / \mathbf{m}^{2} h\right.$ & & & & \\
\hline 3.2 & 24.6 & 72.2 & n.a. & 47.5 \\
\hline 6.8 & 32.0 & 28.6 & 22.2 & 25.5 \\
\hline 10.5 & 32.7 & 18.2 & 9.3 & 29.0 \\
\hline 13.3 & 31.9 & n.a. & n.a. & 28.0 \\
\hline
\end{tabular}

n.a. - not analysed

\subsubsection{Adsorbent/Flux Enhancers on the pilot plant (AnMBR)}

The purpose of this study was adding and observes the behavior of the filtration unit with the addition of a cationic polymer (PermaCare MPE50 ${ }^{\mathrm{TM}}$ ), in the pilot plant.

To evaluate the performance of the polymer in the pilot plant, two experiments were made. In both assays, the polymer was added in the UASB effluent, coming into the bottom of the filtration unit. Samples for physico-chemical analyses from the S.p.6 for experiment 1 during $4.7 \mathrm{~h}$ and experiment 2 during 6.8h, for analysis of COD, TS and VS were collected.

In the first experiment a polymer dosage with a concentration of $430 \mathrm{ppm}$, was added in the effluent UASB entering into the bottom of the filtration unit with a superficial velocity of $60 \mathrm{~m} / \mathrm{h}, \mathrm{TS}=12.72$ and $\mathrm{VS}=9.77 \mathrm{~g} / \mathrm{L}$, and a flux of $11.3 \mathrm{~L} / \mathrm{m}^{2} \mathrm{~h}$.

In the figures below, the evolution of the TMP with the addition of the polymer in the pilot plant along the $4.7 \mathrm{~h}$ was represented. 
A small decreasing of TMP was observed after 16 min (Fig. 5.15), starting to increase again, after the 48 minute, reaching the initial value of TMP before starting the experiment.

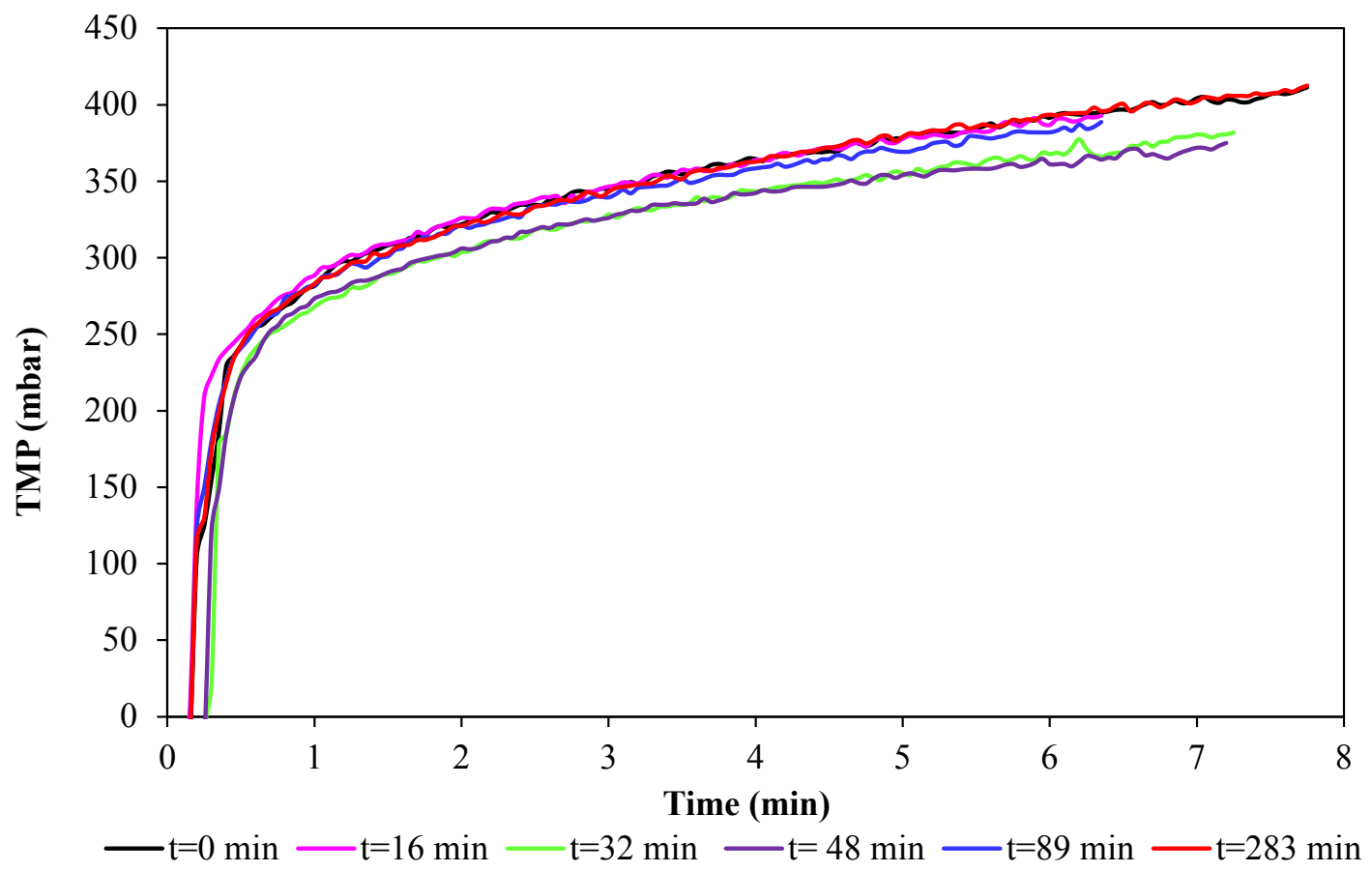

Figure 5.15. Evolution of the TMP during the filtration cycle, in the minute 0, 16, 32, 48 and 283, after adding the polymer MPE50 ${ }^{\mathrm{TM}}$.

The results achieved with the addition of the polymer in the pilot plant showed, that the TMP has not decreased, and there has been no flocculation of the particulate material.

The results have been very different from those carried out at lab-scale, which could be due to various factors, such as the polymer concentration added, the bad agitation of the polymer in the filtration unit and zone where they the polymer is added. 
Table 5.16 summarizes the specific resistance obtained in the membrane tank, during the assay, working with a flux of $11.3 \mathrm{~L} / \mathrm{m}^{2} \mathrm{~h}$ and $\mathrm{u}_{\mathrm{g}}=60 \mathrm{~m} / \mathrm{h}$.

The specific cake resistance decrease between the minute 32 and 48 around $7.14 \pm 0.22 \%$ was observed, corresponding to a decrease in TMP, tCOD and SCOD.

Table 5.16. Specific cake resistance from S.p.6, after adding the polymer, with a flux of $11.3 \mathrm{~L} / \mathrm{m}^{2} \mathrm{~h}$ and $\mathrm{u}_{\mathrm{g}}=60 \mathrm{~m} / \mathrm{h}$.

\begin{tabular}{cc}
\hline Time (min) & $\boldsymbol{\alpha}^{* 1 \mathbf{1 0}^{14}}(\mathbf{m} / \mathbf{K g})$ \\
\hline 0 & 2.05 \\
16 & 2.05 \\
32 & 1.92 \\
48 & 1.93 \\
89 & 2.06 \\
283 & 2.15 \\
\hline
\end{tabular}

In fig. 5.16 was presented the physico-chemical parameters of the S.p.6 with the addition of polymer. During the first $48 \mathrm{~min}$ the tCOD decrease around $7.8 \pm 0.1 \%$, while the sCOD decrease around $33.9 \pm 11.8 \%$. The tCOD on the effluent was unchanged, remaining around $97.3 \pm 3.9 \mathrm{mg} \mathrm{O}_{2} / \mathrm{L}$. 

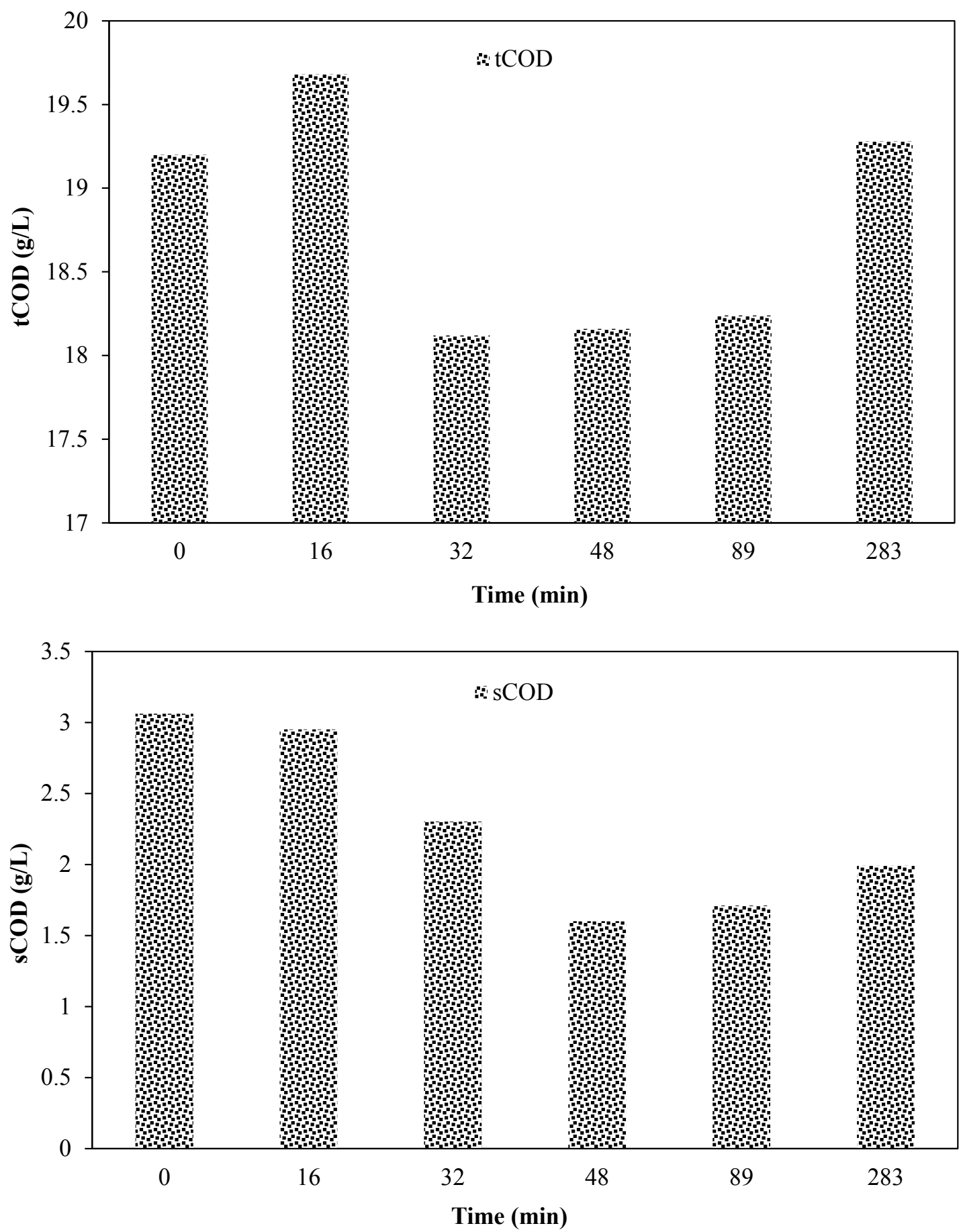

Figure 5.16. Evolution of tCOD and sCOD on S.p.6 during the first assay, after adding the polymer MPE $50^{\mathrm{TM}}$.

In the second experiment a polymer dosage with a concentration of $322 \mathrm{ppm}$, was added in the effluent UASB entering into the bottom of the filtration unit with a superficial velocity in the first $85 \mathrm{~min}$ of $9.98 \mathrm{~m} / \mathrm{h}$ and since minute 85 until 410 was $60 \mathrm{~m} / \mathrm{h}$, TS= 16.24 and $\mathrm{VS}=11.6 \mathrm{~g} / \mathrm{L}$, and a flux of $11.3 \mathrm{~L} / \mathrm{m}^{2} \mathrm{~h}$. 
In the figure 5.17, was represented the evolution of the TMP with the addition of the polymer in the pilot plant, along the $6.8 \mathrm{~h}$. The superficial velocity was decrease $\approx$ $83.4 \%$, to see what their influence on TMP. In this assay the influence of superficial velocity was verified, decreasing the superficial velocity the TMP increases quickly, and increasing the superficial velocity from 9.98 to $60 \mathrm{~m} / \mathrm{h}$, there was a decrease in TMP around $62.5 \%$.

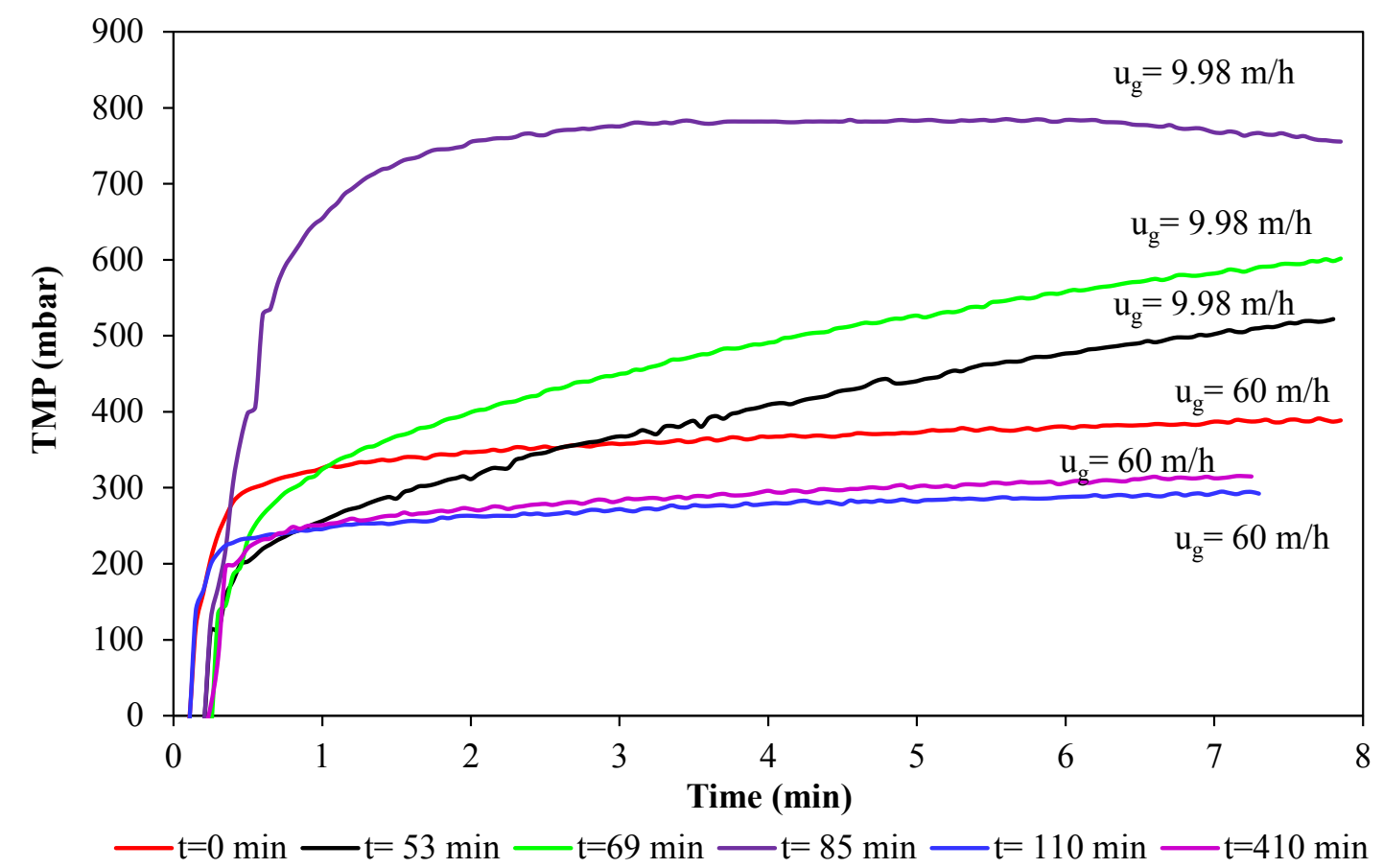

Figure 5.17. Evolution of the TMP during the filtration cycle, in the minute 0, 53, 69, 85,110 and 410 , after adding the polymer MPE $50^{\mathrm{TM}}$.

Table 5.17 summarizes the specific resistance obtained in the filtration unit, during the assay, working with a flux of $11.3 \mathrm{~L} / \mathrm{m}^{2} \mathrm{~h}$ and superficial velocity of 9.98 and $60 \mathrm{~m} / \mathrm{h}$, respectively.

The biogas agitation between the minute 1 and 69 was decreased from 60 to $9.98 \mathrm{~m} / \mathrm{h}$. Immediatly, an increase on the specific cake resistance around $79.4 \%$ was observed, but when reaching the minute 89 the specific cake resistance starts to decrease between 5.7 to $85.1 \%$, due to the effect of the polymer. On minute 110 , the biogas superficial velocity was increased to $60 \mathrm{~m} / \mathrm{h}$ and a quickly decreasing of the specific cake resistance was observed. 
Table 5.17. Specific cake resistance from S.p.6, after adding the polymer with a flux of 11.3 $\mathrm{L} / \mathrm{m}^{2} \mathrm{~h}$ and differents superficial velocities.

\begin{tabular}{ccc}
\hline Time (min) & $\boldsymbol{\alpha}^{*} \mathbf{1 0}^{\mathbf{1 4}}(\mathbf{m} / \mathbf{K g})$ & $\mathbf{u}_{\mathbf{g}}(\mathbf{m} / \mathbf{h})$ \\
\hline 0 & 1.29 & 60 \\
53 & 5.42 & 9.98 \\
69 & 6.25 & 9.98 \\
85 & 1.64 & 9.98 \\
110 & 0.93 & 60 \\
410 & 1.32 & 60 \\
\hline
\end{tabular}

In fig. 5.18, the tCOD and sCOD of the S.p.6 with the addition of polymer was represented. During the entire assay period, tCOD remains constant around of $14.9 \pm 0.64 \mathrm{~g} \mathrm{O} 2 / \mathrm{L}$. On the minute 85 , a small decrease on tCOD due to the effect of the polymer was observed. Meanwhile, a decrease on SCOD from the minute 1 to 110 of $57.6 \pm 1.03 \%$ was observed. The tCOD of the effluent was unchanged, remaining constant around $120.8 \pm 29.3 \mathrm{mg} \mathrm{O}_{2} / \mathrm{L}$. 

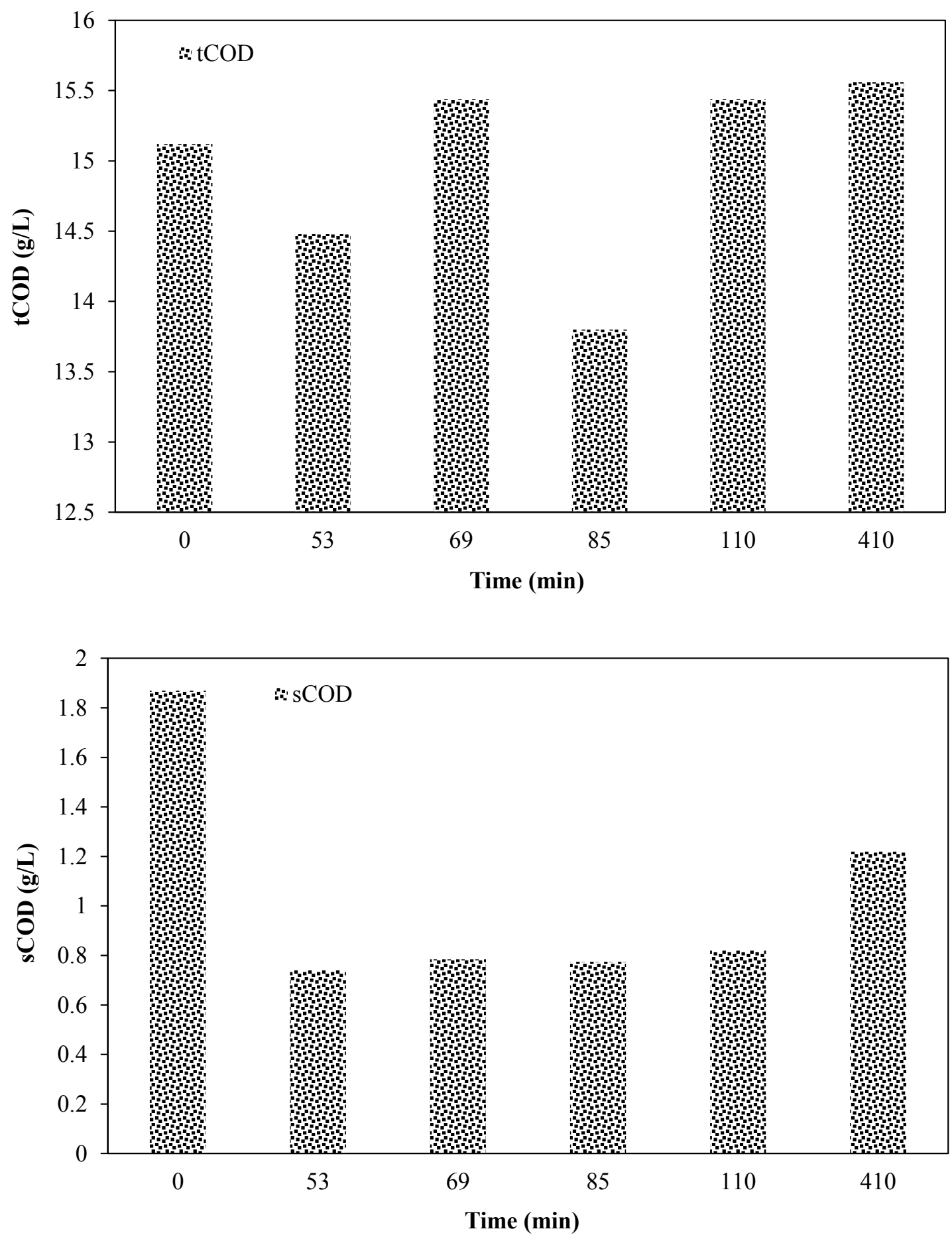

Figure 5.18. Evolution of tCOD and sCOD on S.p.6 during the second assay, after adding the polymer MPE $50^{\mathrm{TM}}$. 


\subsection{Conclusions}

The superficial velocity and the characteristic of biomass (particle size, concentration of solids) were the principal factors which influence the sedimentation of particulate material resulting in a sudden increase in the TMP.

The specific cake resistance in the lower part of the UASB reactor was remained at values around $0.3-0.7 * 10^{14} \mathrm{~m} / \mathrm{Kg}$ to fluxes between $10-12 \mathrm{~L} / \mathrm{m}^{2} \mathrm{~h}$, while increasing the flux the specific resistance increases, possibly due to the compressibility of the cake.

In the zone of the bell, with the fluxes between $10-12 \mathrm{~L} / \mathrm{m}^{2} \mathrm{~h}$, the specific cake resistance increase to values around $1.8-2.2 * 10^{14} \mathrm{~m} / \mathrm{Kg}$.

When the suspension from the bell was filtered by $0.45 \mu \mathrm{m}$, working with a flux between $10-14 \mathrm{~L} / \mathrm{m}^{2} \mathrm{~h}$, the specific cake resistance increased from 2.0 to $3.84 * 10^{14}$ $\mathrm{m} / \mathrm{Kg}$.

At lab-scale, the use of MPE50 allowed flocculation and the improving of theTCOD, SCOD and turbidity.

The results with the polymer in the AnMBR are very scarce, because the concentration of polymer used was very low compared with the lab-scale, but a slight difference in tCOD, sCOD and in specific cake resistance was observed. 


\subsection{References}

Akram, A., Stuckey, D.C., 2008. Flux and performance improvement in a submerged anaerobic membrane bioreactor ( SAMBR ) using powdered activated carbon (PAC). Process Biochem. 43, 93-102.

Buyukkamaci, N., 2004. Biological sludge conditioning by Fenton's reagent. Process Biochem. 39, 1503-1506.

Charfi, A., Amar, N. Ben, 2012. Analysis of fouling mechanisms in anaerobic membrane bioreactors Total Suspended Solid concentration. Water Res. 46, 26372650 .

Chu, H.P., Li, X.Y., 2005. Membrane fouling in a membrane bioreactor (MBR): Sludge cake formation and fouling characteristics. Biotechnol. Bioeng. 90, 323-331.

Coca, M., Peña, M., González, G., 2005. Variables affecting efficiency of molasses fermentation wastewater ozonation. Chemosphere 60, 1408-1415.

Dereli, R.K., Grelot, A., Heffernan, B., van der Zee, F.P., van Lier, J.B., 2014. Implications of changes in solids retention time on long term evolution of sludge filterability in anaerobic membrane bioreactors treating high strength industrial wastewater. Water Res. 59, 11-22.

Desai, R., Sahu, O., 2014. Comparatively Study of Polymer and Regular Coagulant for Municipal Waste Water Treatment 2, 82-91.

Gao, D.W., Zhang, T., Tang, C.Y.Y., Wu, W.M., Wong, C.Y., Lee, Y.H., Yeh, D.H., Criddle, C.S., 2010. Membrane fouling in an anaerobic membrane bioreactor: Differences in relative abundance of bacterial species in the membrane foulant layer and in suspension. J. Memb. Sci. 364, 331-338.

He, Y., Xu, P., Li, C., Zhang, B., 2005. High-concentration food wastewater treatment by an anaerobic membrane bioreactor. Water Res. 39, 4110-4118.

Ho, J., Sung, S., 2009. Effects of solid concentrations and cross-flow hydrodynamics on microfiltration of anaerobic sludge. J. Memb. Sci. 345, 142-147. 
Hu, A., Stuckey, D., 2007. Activated Carbon Addition to a Submerged Anaerobic Membrane Bioreactor: Effect on Performance, Transmembrane Pressure, and Flux. J. Environ. Eng. 133, 73-80.

Hwang, B.K., Lee, W.N., Park, P.K., Lee, C.H., Chang, I.S., 2007. Effect of membrane fouling reducer on cake structure and membrane permeability in membrane bioreactor. J. Memb. Sci. 288, 149-156.

Kanai, M., Ferre, V., Wakahara, S., Yamamoto, T., Moro, M., 2010. A novel combination of methane fermentation and MBR-Kubota Submerged Anaerobic Membrane Bioreactor process. Desalination 250, 964-967.

Kang, I.J., Yoon, S.H., Lee, C.H., 2002. Comparison of the filtration characteristics of organic and inorganic membranes in a membrane-coupled anaerobic bioreactor. Water Res. 36, 1803-1813.

Karimi, A.A., Vickers, J.C., Harasick, R.F., 1999. Microfiltration goes. Am. Water Work. Assoc. 91, 90-103.

Laspidou, C.S., Rittmann, B.E., 2002. Non-steady state modeling of extracellular polymeric substances, soluble microbial products, and active and inert biomass. Water Res. 36, 1983-1992.

Le Clech, P., Jefferson, B., Chang, I.S., Judd, S.J., 2003. Critical flux determination by the flux-step method in a submerged membrane bioreactor. J. Memb. Sci. 227, 8193.

Lee, W., Kang, S., Shin, H., 2003. Sludge characteristics and their contribution to microfiltration in submerged membrane bioreactors. J. Memb. Sci. 216, 217-227.

Liao, B.-Q., Kraemer, J.T., Bagley, D.M., 2006. Anaerobic Membrane Bioreactors: Applications and Research Directions. Crit. Rev. Environ. Sci. Technol. 36, 489530.

Lin, H., Peng, W., Zhang, M., Chen, J., Hong, H., Zhang, Y., 2013. A review on anaerobic membrane bioreactors: Applications, membrane fouling and future perspectives. Desalination 314, 169-188. 
Lin, H.J., Xie, K., Mahendran, B., Bagley, D.M., Leung, K.T., Liss, S.N., Liao, B.Q., 2009. Sludge properties and their effects on membrane fouling in submerged anaerobic membrane bioreactors (SAnMBRs). Water Res. 43, 3827-3837.

Massé, A., Spérandio, M., Cabassud, C., 2006. Comparison of sludge characteristics and performance of a submerged membrane bioreactor and an activated sludge process at high solids retention time. Water Res. 40, 2405-2415.

Migo, V.P., Matsumura, M., Del Rosario, E.J., Kataoka, H., 1993. Decolorization of molasses wastewater using an inorganic flocculant. J. Ferment. Bioeng. 75, 438442.

Montgomery, D., Peck, E., Vining, G., 2001. Introduction to Linear Regression Analysis, John Wiley \& Sons, New York.

Mutlu, S.H., Yetis, U., Gurkan, T., Yilmaz, L., 2002. Decolorization of wastewater of a baker's yeast plant by membrane processes. Water Res. 36, 609-616.

Ng, H.Y., Hermanowicz, S.W., 2005. Specific Resistance to Filtration of Biomass from Membrane Bioreactor Reactor and Activated Sludge: Effects of Exocellular Polymeric Substances and Dispersed Microorganisms. Water Environ. Res. 77, $187-192$.

Nghiem, L.D., Oschmann, N., Schäfer, A.I., 2006. Fouling in greywater recycling by direct ultrafiltration. Desalination 187, 283-290.

Ozgun, H., Kaan, R., Evren, M., Kinaci, C., Spanjers, H., Lier, J.B. Van, 2013. A review of anaerobic membrane bioreactors for municipal wastewater treatment: Integration options, limitations and expectations. Sep. Purif. Technol. 118, 89104.

Perry, R.H., Green, D.W., 1999. Perry's Chemical Engineers' Handbook, seventh ed., McGraw-Hill, New York.

Ryan, D., Gadd, A., Kavanagh, J., Zhou, M., Barton, G., 2008. A comparison of coagulant dosing options for the remediation of molasses process water. Sep. Purif. Technol. 58, 347-352. 
Schäfer, A.I., Fane, A.G., Waite, T.D., 2001. Cost Factors and Chemical Pretreatment Effects in the Membrane Filtration of Waters Containing Natural Organic Matter. Water Res. 35, 1509-1517.

Trzcinski, A.P., Stuckey, D.C., 2010. Treatment of municipal solid waste leachate using a submerged anaerobic membrane bioreactor at mesophilic and psychrophilic temperatures: Analysis of recalcitrants in the permeate using GC-MS. Water Res. 44, 671-680.

Wang, Y., Liang, Z., Yuan, X., Xu, Y., 2005. Preparation of cellular iron using wastes and its application in dyeing wastewater treatment. J. Porous Mater. 12, 225-232.

Wisniewski, C., Grasmick, A., 1998. Floc size distribution in a membrane bioreactor and consequences for membrane fouling. Colloids Surfaces A Physicochem. Eng. Asp. 138, 403-411.

Wolfrom, M.L., Kolb, D.K., Langer, A.W., 1953. Chemical Interactions of Amino Compounds and Sugars. VII. pH Dependency. J. Am. Chem. Soc. 75, 3471-3473.

Wu, B., An, Y., Li, Y., Sin, F., 2009. Effect of adsorption / coagulation on membrane fouling in microfiltration process post-treating anaerobic digestion effluent. Desalination 242, 183-192.

Yoon, S.H., Collins, J.H., Musale, D., Sundararajan, S., Tsai, S.P., Hallsby, G.A., Kong, J.F., Koppes, J., Cachia, P., 2005. Effects of flux enhancing polymer on the characteristics of sludge in membrane bioreactor process. Water Sci. Technol. 51, $151-157$. 


\title{
CHAPTER 6
}

\section{A novel configuration for anaerobic submerged membrane bioreactor (AnSMBR) configuration. Long- term treatment of municipal wastewater under psychrophilic conditions}

\begin{abstract}
A novel design for a pilot scale anaerobic submerged membrane bioreactor (AnSMBR) equipped with an ultrafiltration unit, treating municipal wastewater at $18 \pm 2^{\circ} \mathrm{C}$, and inoculated with a mesophilic inoculum without acclimation, was implemented and evaluated over 3 years of stable operation. The AnSMBR operated with a volumetric loading rate between 1.6 to $2.0 \mathrm{Kg} \mathrm{COD} / \mathrm{m}^{3}{ }_{\text {UASB }}$.d, 12.8 to $14.2 \mathrm{~h}$ hydraulic retention time, and reached a tCOD removal efficiency of around 90\%. Biosolid production was

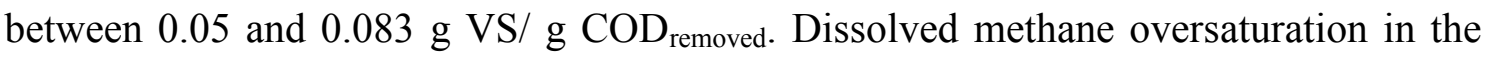
effluent was observed, reaching average values of $19.1 \pm 0.84 \mathrm{mg} \mathrm{CH}_{4} / \mathrm{L}$. The permeate flow rate ranged from 10 to $14 \mathrm{~L} / \mathrm{m}^{2} \mathrm{~h}$ with trans-membrane pressure (TMP) values of 400-550 mbar, using cycles of $30 \mathrm{~s}$ backwash, $7.5 \mathrm{~min}$ filtration, and continuous biogas sparging $(9-16 \mathrm{~m} / \mathrm{h})$. During the three years of continuous operation, the membrane was not physically or chemically cleaned.
\end{abstract}





\title{
A novel configuration for an anaerobic submerged membrane bioreactor (AnSMBR). Long-term treatment of municipal wastewater under psychrophilic conditions
}

\author{
J. Gouveia ${ }^{\text {a }}$, F. Plaza ${ }^{\text {b }}$, G. Garralon ${ }^{\text {b }}$, F. Fdz-Polanco ${ }^{\text {a }}$, M. Peña ${ }^{a, *}$ \\ a Department of Chemical Engineering and Environmental Technology, School of Industrial Engineering, Dr. Mergelina s/n, 47011, University of Valladolid, Valladolid, Spain \\ ${ }^{\mathrm{b}}$ CADAGUA, Gran Via 45, Bilbao, Spain
}

\section{H I G H L I G H T S}

- Viability of the new membrane configuration for treating municipal wastewater.

- The configuration of the AnSMBR allows better distribution of the accumulated solid.

- Solid concentration and biogas sparging; main parameters for long-term operation.

- Three years of continuous operation without physical and chemical cleaning.

\section{A R T I C L E I N F O}

\section{Article history:}

Received 30 June 2015

Received in revised form 5 September 2015

Accepted 10 September 2015

Available online 18 September 2015

\section{Keywords:}

Submerged anaerobic membrane bioreactor Psychrophilic temperature

Municipal wastewater

Methane oversaturation

\begin{abstract}
A B S T R A C T
A novel design for a pilot scale anaerobic submerged membrane bioreactor (AnSMBR) equipped with an ultrafiltration unit, treating municipal wastewater at $18 \pm 2{ }^{\circ} \mathrm{C}$, and inoculated with a mesophilic inoculum without acclimation, was implemented and evaluated over 3 years of stable operation. The AnSMBR operated with a volumetric loading rate between 1.6 to $2.0 \mathrm{~kg} \mathrm{COD} / \mathrm{m}_{\mathrm{UASB}}^{3} \mathrm{~d}, 12.8$ to $14.2 \mathrm{~h}$ hydraulic retention time, and reached a tCOD removal efficiency of around 90\%. Biosolid production was between 0.05 and $0.083 \mathrm{~g} \mathrm{VS} / \mathrm{g} \mathrm{COD}_{\text {removed. }}$. Dissolved methane oversaturation in the effluent was observed, reaching average values of $19.1 \pm 0.84 \mathrm{mg} \mathrm{CH} / \mathrm{L}$. The permeate flow rate ranged from 10 to $14 \mathrm{~L} / \mathrm{m}^{2} \mathrm{~h}$ with transmembrane pressure (TMP) values of $400-550$ mbar, using cycles of $30 \mathrm{~s}$ backwash, $7.5 \mathrm{~min}$ filtration, and continuous biogas sparging $(9-16 \mathrm{~m} / \mathrm{h})$. During the three years of continuous operation, the membrane was not physically or chemically cleaned.
\end{abstract}

(c) 2015 Elsevier Ltd. All rights reserved.

\section{Introduction}

The anaerobic treatment of wastewater has many advantages over aerobic treatment. It requires low energy consumption and low macro/micro-nutrients, while it provides low wastage of biological solids, and transforms the organic matter into valuable biogas. On the other hand, it has some disadvantages such as process sensitivity, vulnerability, odor problems, long start-up period, and post treatments in order to achieve discharge standards. In addition, during anaerobic treatments, greenhouse gas emissions are lower in comparison to aerobic technologies, if methane is used as an energy source (Bialek et al., 2014; Lew et al., 2009). On the contrary, the loss of dissolved methane in the effluent should be avoided, not only due to the loss of energy, but also because of

\footnotetext{
* Corresponding author. Tel.: +34 983423166.

E-mail address: pena@iq.uva.es (M. Peña).
}

its higher global warming potential (Matsuura et al., 2015; Smith et al., 2013). Over the past years, anaerobic membrane technology has been of growing interest and has been investigated for the treatment of different wastewaters, including municipal and industrial wastewaters (Lin et al., 2013; Ozgun et al., 2013; Skouteris et al., 2012; Smith et al., 2012). Anaerobic membrane technology brings together the advantages of anaerobic processes with the production of solid free effluent, which provides an appropriate alternative to complete biomass retention, enabling an independent control of the hydraulic residence time (HRT) and the solid retention time (SRT). One of the goals of anaerobic treatment processes is to maintain a long SRT because of the slow growth rate of anaerobic microorganisms, especially when operating at psychrophilic conditions and with low strength wastewater, such as municipal wastewater (van Lier et al., 2001). The anaerobic membrane bioreactor (AnMBR) produces a better effluent quality in terms of suspended solids, chemical oxygen demand (COD), and 



\subsection{Introduction}

The anaerobic treatment of wastewater has many advantages over aerobic treatment. It requires low energy consumption and low macro/micro-nutrients, while it provides low wastage of biological solids, and transforms the organic matter into valuable biogas. On the other hand, it has some disadvantages such as process sensitivity, vulnerability, odor problems, long start-up period, and post treatments in order to achieve discharge standards. In addition, during anaerobic treatments, greenhouse gas emissions are lower in comparison to aerobic technologies, if methane is used as an energy source (Bialek et al., 2014; Lew et al., 2009). On the contrary, the loss of dissolved methane in the effluent should be avoided, not only due to the loss of energy, but also because of its higher global warming potential (Matsuura et al., 2015; Smith et al., 2013). Over the past years, anaerobic membrane technology has been of growing interest and has been investigated for the treatment of different wastewaters, including municipal and industrial wastewaters (Lin et al., 2013; Ozgun et al., 2013; Skouteris et al., 2012; Smith et al., 2012). Anaerobic membrane technology brings together the advantages of anaerobic processes with the production of solid free effluent, which provides an appropriate alternative to complete biomass retention, enabling an independent control of the hydraulic residence time (HRT) and the solid retention time (SRT). One of the goals of anaerobic treatment processes is to maintain a long SRT because of the slow growth rate of anaerobic microorganisms, especially when operating at psychrophilic conditions and with low strength wastewater, such as municipal wastewater (van Lier et al., 2001). The anaerobic membrane bioreactor (AnMBR) produces a better effluent quality in terms of suspended solids, chemical oxygen demand (COD), and pathogen count. Furthermore, there is a possibility of reusing and recycling the treated effluent for non-drinkable purposes and for agricultural irrigation. The anaerobic membrane technology is a viable technology for the treatment of municipal wastewater at psychrophilic conditions in cold countries (Smith et al., 2015, 2013). Nevertheless, due to the low temperature and the low strength wastewater, the recovery of dissolved methane is key to approaching energy-neutral operation for domestic wastewater treatment (Smith et al., 2012). The membrane fouling and the low permeate flux compared with the aerobic membrane bioreactor are the main disadvantages of anaerobic membrane technology. The AnMBR has two possible configurations, 
submerged and side-stream. In the former, the membrane is directly immersed in the mixed liquor, while in the latter the membrane is located outside the bioreactor and the mixed liquor circulates through it at an elevated flow, which is required to achieve a high cross flow velocity. Nowadays, submerged AnMBR is the more commonly applied configuration due to its lower energy consumption (Judd, 2006). In addition, the shear stress caused by the high velocity of the side-stream configuration has a negative effect on the microbial activity.

In the submerged configuration, the membrane is placed inside the reactor or inside an external tank. Depending on the type of the reactor or the degree of mixing, the placement of the membrane inside the reactor or inside an external tank could contribute in different ways to the fouling of the membrane, and therefore to the different energy consumption in long-term maintenance. In a previous study, Gouveia et al., (2015), operating a pilot scale AnMBR with a submerged membrane located in an external tank connected to the upflow anaerobic sludge blanket reactor (UASB), observed an accumulation of solids at the bottom of the membrane module. This suspension showed poor flow ability and sedimentability characteristics, impeding its recirculation to the UASB reactor, thus preventing adequate contact with the active biomass and consequently its possible biodegradation. In addition, the accumulation of this suspension contributes to the increase in solid concentration in the area surrounding the membrane, and therefore to the increased fouling of the membrane. In order to facilitate the circulation of solids between the membrane section and the biological section, and to try to reduce the fouling of the membrane, this paper proposes a novel configuration in which the membrane is placed on top of the UASB reactor. Thereby, the aim of this work was to experimentally study the general performance of a pilot scale AnSMBR with a novel membrane configuration, UASB reactor and filtration section in a single unit, and determine the long-term feasibility of the treatment of municipal wastewater under psychrophilic conditions. 


\subsection{Material and methods}

\subsubsection{AnSMBR configuration}

Fig. 6.1 shows the experimental pilot plant set up. Raw sewage is pumped from the municipal sewer to a rotary sieve (defender TR-40/25 Toro Wastewater Equipment Industries), pre-treated in a circular primary settler (with a total volume of $25 \mathrm{~L}$ and HRT between 1 and $3 \mathrm{~h}$ ) and then pumped to the UASB reactor with a submerged ultrafiltration membrane placed on top of the reactor. In order to improve settling ability, two baffles are placed between the three-phase separator and the ultrafiltration section. The total volume of the UASB reactor was $326 \mathrm{~L}$, (useful volume of $284 \mathrm{~L}$ ). The filtration section (total volume $=175 \mathrm{~L}$ ) was equipped with two ultrafiltration membrane modules (ZW-10 Zenon, GE), with a mean pore size of $0.04 \mu \mathrm{m}$, and a filtration area of $0.93 \mathrm{~m}^{2} /$ module. Both settler and reactor were placed in a room provided with an air-conditioned system in order to control the temperature of the UASB reactor at $18^{\circ} \mathrm{C}$. The pilot plant was equipped with biogas flow meters, pressure meters, and two temperature sensors. One sensor was placed at the bottom of the UASB reactor ( $1 \mathrm{~m}$ from the bottom), and the other one was placed on top, in the filtration section ( $1 \mathrm{~m}$ from the top). Temperature and pressure filtration were stored online using a data acquisition system by Pico Technology.

In order to control the membrane fouling and to maintain the TMP biogas sparging, relaxation time, and permeate back-flush were used. The initial operation cycle was fixed at 15 minutes filtration, 10 seconds relaxation time, 1 minute back-flush and a further 10 seconds relaxation time. The biogas was continuously sparged, (coarse bubbles) at the bottom of the hollow fibers with a superficial velocity of between 8 and $16 \mathrm{~m} / \mathrm{h}$. The operation of the AnSMBR was divided into two periods; Period I, before reinoculation (day 0-308), and Period II, after reinoculation (day 309-1060). During Period II, the AnSMBR was operated without recirculation from the filtration section to the bottom of the UASB reactor (period II.1 from day 309 to day 491) and with recirculation (period II.2 from day 492 to day 1060). The upflow velocity operating without recirculation was $0.12 \pm 0.03 \mathrm{~m} / \mathrm{h}$, and with recirculation $0.34 \pm 0.03 \mathrm{~m} / \mathrm{h}$. 


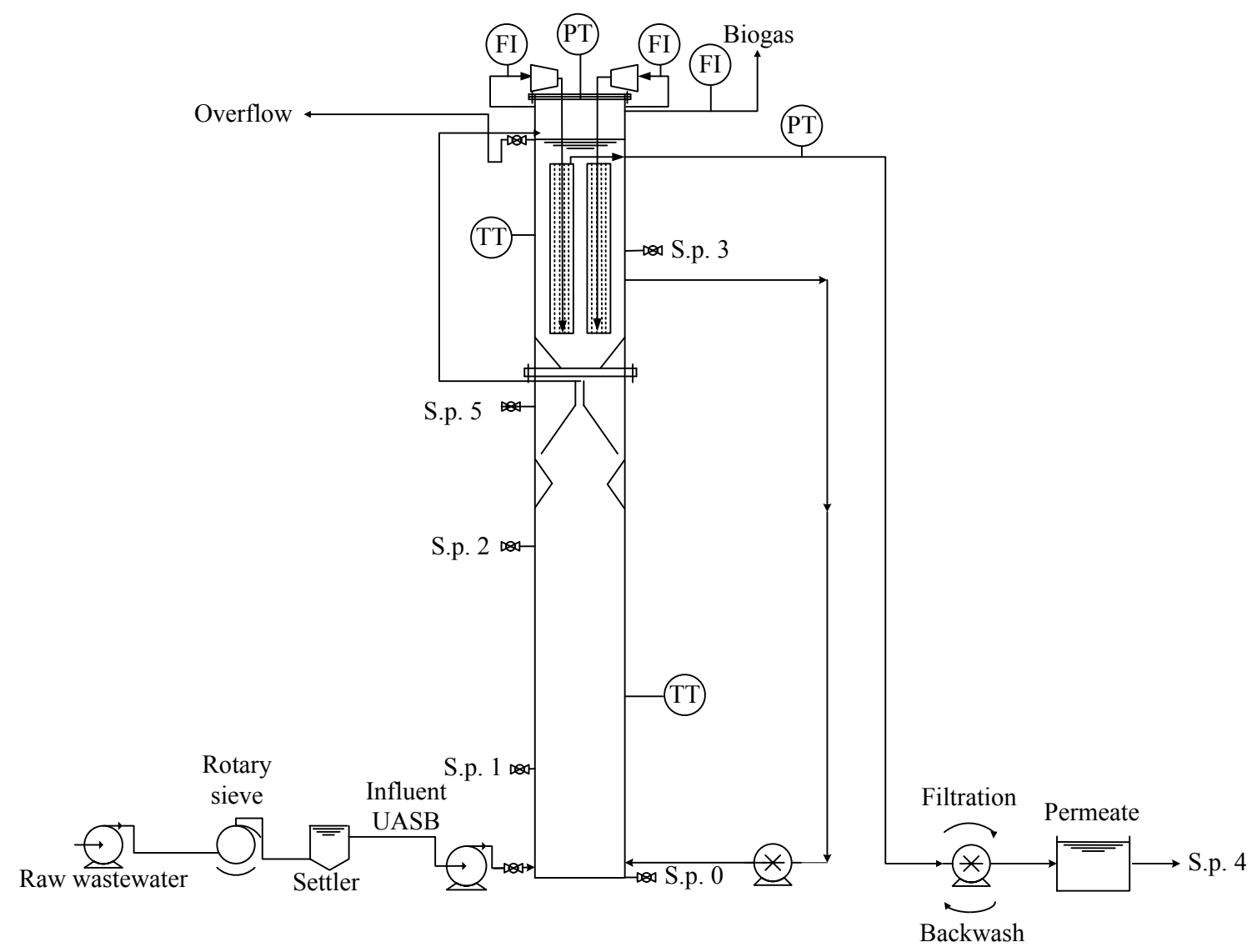

Figure 6.1. AnSMBR pilot plant flow scheme (FI- Flow-rate Indicator; PT- Pressure Transmitter; TT- Temperature Transmitter; S.p.- Sampling points).

\subsubsection{Inoculum and feed wastewater}

The reactor was inoculated with granular sludge (6.6 $\mathrm{kg}$ of volatile solid (VS)) from a mesophilic anaerobic reactor treating wastewater from a paper recycling factory without any previous acclimatization to psychrophilic conditions. After 10 months of operation, the reactor was reinoculated with granular sludge $(7.5 \mathrm{Kg} \mathrm{VS})$ from the same mesophilic anaerobic reactor also without acclimation. The pilot plant was fed with raw municipal wastewater from the city of Valladolid obtained from a nearby sewer.

\subsubsection{Chemical assays and sampling}

Samples were taken twice a week from the pilot plant to monitor the process performance. The sampling points (S.p.) 0, 1, 2, 3, 5 and effluent (4), are shown in Figure 6.1. Alkalinity, tCOD, sCOD, total solids (TS), volatile solids (VS), total suspended solids (TSS), volatile suspended solids (VSS), biological oxygen demand $\left(\mathrm{BOD}_{5}\right)$, total nitrogen $(\mathrm{N}-\mathrm{TKN})$ and ammonia nitrogen $\left(\mathrm{N}-\mathrm{NH}_{4}{ }^{+}\right)$were determined 
according to the Standard methods for the examination of water and wastewater (APHA., AWWA. and WPCF., 2005). sCOD was determined following sample filtration through $0.45 \mu \mathrm{m}$. The concentrations of volatile fatty acids (VFAs) were determined by gas chromatography using Agilent 7820A GC-FID equipped with a G4513A autosampler and a Chromosorb WAW packed column $(2 \mathrm{~m} \times 1 / 8$ " $\times 2.1 \mathrm{~mm}$ SS) $\left(10 \%\right.$ SP $1000,1 \% \mathrm{H}_{3} \mathrm{PO}_{4}$, WAW 100/120) (Teknokroma, Spain). Nitrate nitrogen $\left(\mathrm{NO}_{3}{ }^{-}-\mathrm{N}\right)$, nitrite nitrogen $\left(\mathrm{NO}_{2}{ }^{-}-\mathrm{N}\right)$, chloride $\left(\mathrm{Cl}^{-}\right)$, sulphate $\left(\mathrm{SO}_{4}{ }^{2-}\right)$ and soluble phosphorus $\left(\mathrm{P}-\mathrm{PO}_{4}{ }^{3-}\right)$ concentrations were analyzed by HPLC-IC using a Waters 515 HPLC pump (Waters, Milford, USA) coupled with an ion conductivity detector (Waters 432, Milford, USA) and equipped with an IC-Pak Anion Guard-Pak column (Waters, Milford, USA) and an IC-Pak Anion HC (150 mm×4.6 mm) column (Waters, Milford, USA). Biogas composition was analyzed using a gas chromatograph (Varian CP-3800, Palo Alto, CA, USA) coupled with a thermal conductivity detector and equipped with a $\mathrm{CP}-$ Molsieve $5 \mathrm{~A}(15 \mathrm{~m} \times 0.53 \mathrm{~mm} \times 15 \mu \mathrm{m})$ and a CP-Pora BOND Q $(25 \mathrm{~m} \times 0.53$ $\mathrm{mm} \times 15 \mu \mathrm{m}$ ) columns. Helium was used as the carrier gas.

\subsubsection{Determination of dissolved $\mathrm{CH}_{4}$}

The methodology used for the sampling and determination of dissolved methane in the reactor and in the effluent of the AnSMBR was as follows:

1. A known volume of liquid was carefully collected in $2.15 \mathrm{~L}$ glass bottles avoiding any turbulence. The bottles were immediately closed with rubber stoppers and sealed with aluminum caps.

2. After filling, the bottle was manually agitated for $3 \mathrm{~min}$ in order to desorb the dissolved methane in the liquid phase.

3. Next, the pressure in the head space was measured and the gas contained was sampled and analyzed to determine the gas composition. The amount of desorbed methane was calculated according to the ideal gas behavior. (At the end of the experiment, the volume of the gas phase was assessed by calculating the difference between the total volume of the bottle and the exact measured volume of the liquid phase). 
4. The bottles were kept from 3 to 4 hours at a controlled temperature in order to reach equilibrium between the gas phase and liquid phase.

5. Finally, the head space of the bottle was again sampled and analyzed to determine the gas composition. The remaining methane dissolved in the liquid phase was calculated according to Henry's Law, with a constant value of $1.48 * 10^{-3} \mathrm{~mol} \mathrm{~atm}^{-1} \mathrm{~L}^{-1}$ at $20^{\circ} \mathrm{C}$ for water (Metcalf \&Eddy, 2003).

The total amount of dissolved methane in each sample was calculated taking into account the desorbed methane plus the methane in the liquid phase when in equilibrium with the desorbed gas phase. The percentage of oversaturation was calculated on the basis of the theoretical value of methane dissolved in the liquid phase, calculated according to Henry's Law using the constant formerly mentioned for clean water. It was calculated considering local atmospheric pressure for the effluent, the local atmospheric pressure plus the water column $(1.9 \mathrm{~m})$ for sampling point 2 , and taking into account a methane composition in the biogas phase of $80 \%$ for both samples. The conductivity of the wastewater was around $950-1400 \mu \mathrm{S} / \mathrm{cm}$.

\subsubsection{Biochemical methane potential (BMP) assays}

Biochemical methane potential assays at mesophilic conditions were carried out from the solid waste purged from the filtration section. The substrate/inoculum ratio selected for the BMP assays was between 0.23 and $0.40 \mathrm{~g} \mathrm{VS} / \mathrm{g}$ VS. The methodology used for the BMP assay is described in detail in a previous work (Gouveia et al., 2015).

\subsection{Results and discussion}

The UASB was continuously fed with municipal wastewater, pre-treated in a rotary sieve (1 mm mesh) and a primary settler. The main characteristics of the wastewater feeding the UASB are listed in Table 6.1. Particulate COD represents between 28 and $46 \%$ of tCOD. The $\mathrm{pH}$ of the wastewater was constant throughout the operation with values around 7.2 \pm 0.6 . The alkalinity of the wastewater reached values of $494.7 \pm 40.4$ $\mathrm{mg} \mathrm{CaCO} / \mathrm{L}$. As shown in the figures, the reactor operated continuously for 1060 days. The whole operation is divided into three periods: I. Start-up, II.1 operation without recirculation and II.2 operation with recirculation. 
Table 6.1. Presettled wastewater characteristics fed to the UASB (average values).

\begin{tabular}{cc}
\hline Parameter & Influent $(\mathrm{mg} / \mathrm{L})$ \\
\hline tCOD & $978 \pm 210$ \\
sCOD & $610 \pm 146$ \\
tBOD $_{5}$ & $474 \pm 203$ \\
sBOD $_{5}$ & $329 \pm 146$ \\
$\mathrm{TS}$ & $83.0 \pm 8.63$ \\
$\mathrm{VS}$ & $51.2 \pm 8.13$ \\
$\mathrm{~N}-\mathrm{TNK}$ & $92 \pm 10$ \\
$\mathrm{~N}-\mathrm{NH}_{4}{ }^{+}$ & $75 \pm 16$ \\
$\mathrm{P}^{-\mathrm{PO}_{4}}$ & $10 \pm 2$ \\
$\mathrm{SO}_{4}{ }^{2-}$ & $47 \pm 25$ \\
\hline
\end{tabular}

\subsubsection{Start-up}

The UASB reactor was started-up with a Food/Microorganism ratio of $0.06 \mathrm{~g} \mathrm{tCOD/g}$ VS $d$ and gradually increased by decreasing the hydraulic residence time. As shown in Figure 6.2 during period I (from day 0 to day 308), after 3 months of operation with tCOD removal efficiencies of around $70 \%$, the coincidence of two negative factors (two weeks out of operation due to pumping problems from the sewer, as well as a very low temperature of $12^{\circ} \mathrm{C}$ contributed to VFA accumulation (370 mg $\mathrm{AcH}$ ) and the subsequent loss of COD removal efficiency $(<50 \%)$. In order to recover the removal efficiency and to avoid VFA accumulation, the action undertaken was to decrease the influent flow rate, while simultaneously increasing the inlet temperature to $18^{\circ} \mathrm{C}$. This action was sufficient to improve the performance of the COD removal when operating at a high hydraulic residence time (HRT $=56-28 \mathrm{~h})$. Nevertheless, the removal efficiency decreased markedly with increasing organic loading rates, even after 75-100 days of the episode of acidification. Methanogenic activity tests, using the sludge from the bottom of the UASB reactor, were carried out at $18^{\circ} \mathrm{C}$, obtaining values of $0.004 \mathrm{~g} \mathrm{COD} / \mathrm{g} \mathrm{VS} \mathrm{d}$ and thus indicating that at low temperature it is very difficult to recover normal conditions after a severe episode of VFA inhibition. In order to recover this activity, part of the sludge was purged and the reactor was reinoculated (day 308) with granular 
sludge. As a result of this reinoculation, the reactor could be operated with higher volumetric loading rates, although with a slow but progressive decrease in the hydraulic residence time in order to obtain a higher COD removal efficiency. This behaviour indicates a slow adaptation to psycrophilic conditions. The slow adaptation to psychrophilic conditions was also observed in a previous work of Gouveia et al., (2015) operating an AnMBR and inoculated with flocculent sludge from a mesophilic anaerobic digester from the municipal wastewater treatment plant of Valladolid. A long start-up period is needed to obtain higher tCOD removal when mesophilic sludge is used to inoculate a psychrophilic reactor. Shin et al., (2014), worked with an anaerobic fluidized membrane bioreactor (SAF-MBR) at temperatures of at $8-15^{\circ} \mathrm{C}$ during the first winter. At this point, before acclimation, removal efficiencies of $81 \%$ and $85 \%$ were obtained for $\mathrm{COD}$ and $\mathrm{BOD}_{5}$ respectively. After becoming fully acclimated, during the following summer and winter the COD removals increased to $94 \%$ and $90 \%$. Nevertheless, McKeown et al., (2009), working with a laboratory-scale expanded granular sludge bed-anaerobic filter (EGSB-AF) hybrid bioreactor between $15^{\circ} \mathrm{C}$ and $4^{\circ} \mathrm{C}$, and treating synthetic, volatile fatty acid (VFA) - based wastewater, concluded that mesophilic inocula can physiologically adapt to sub-optimal operational temperatures, reaching efficiencies and sludge loading rates at $4^{\circ} \mathrm{C}$ (day 1243) which are comparable to those achieved at $15^{\circ} \mathrm{C}$ (day 0). Bowen et al., (2014) indicate that one of the strategies for seeding low-temperature anaerobic reactors is the use of mesophilic sludge acclimated to low temperatures. They conclude that the sludge sourced from a bioreactor acclimated to treating domestic wastewater at $15^{\circ} \mathrm{C}$ would not be able to function below $8^{\circ} \mathrm{C}$. 
(a)

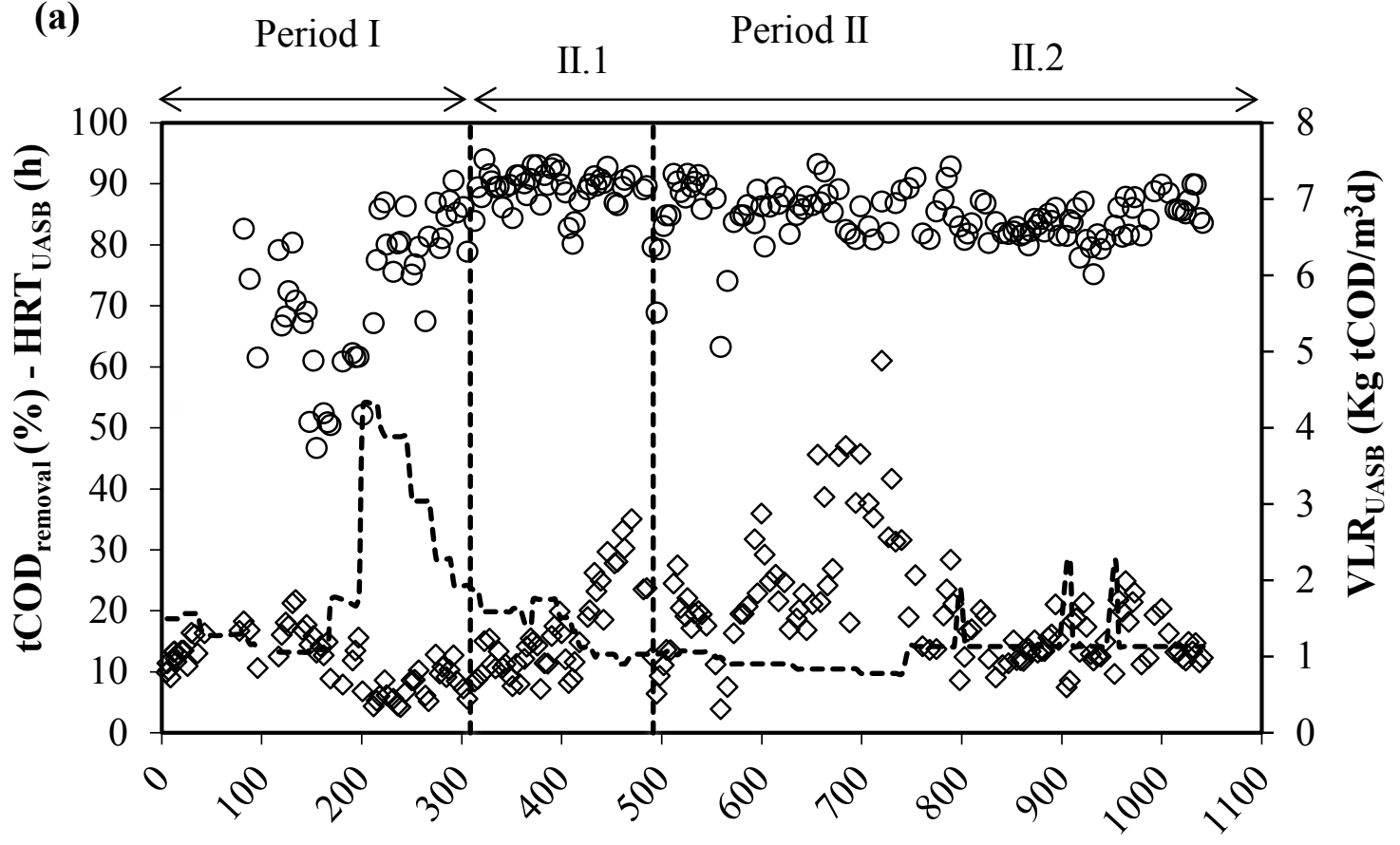

Time (days)

o tCOD removal $\diamond \mathrm{VLR}_{\mathrm{UASB}}---\mathrm{HRT}_{\mathrm{UASB}}$

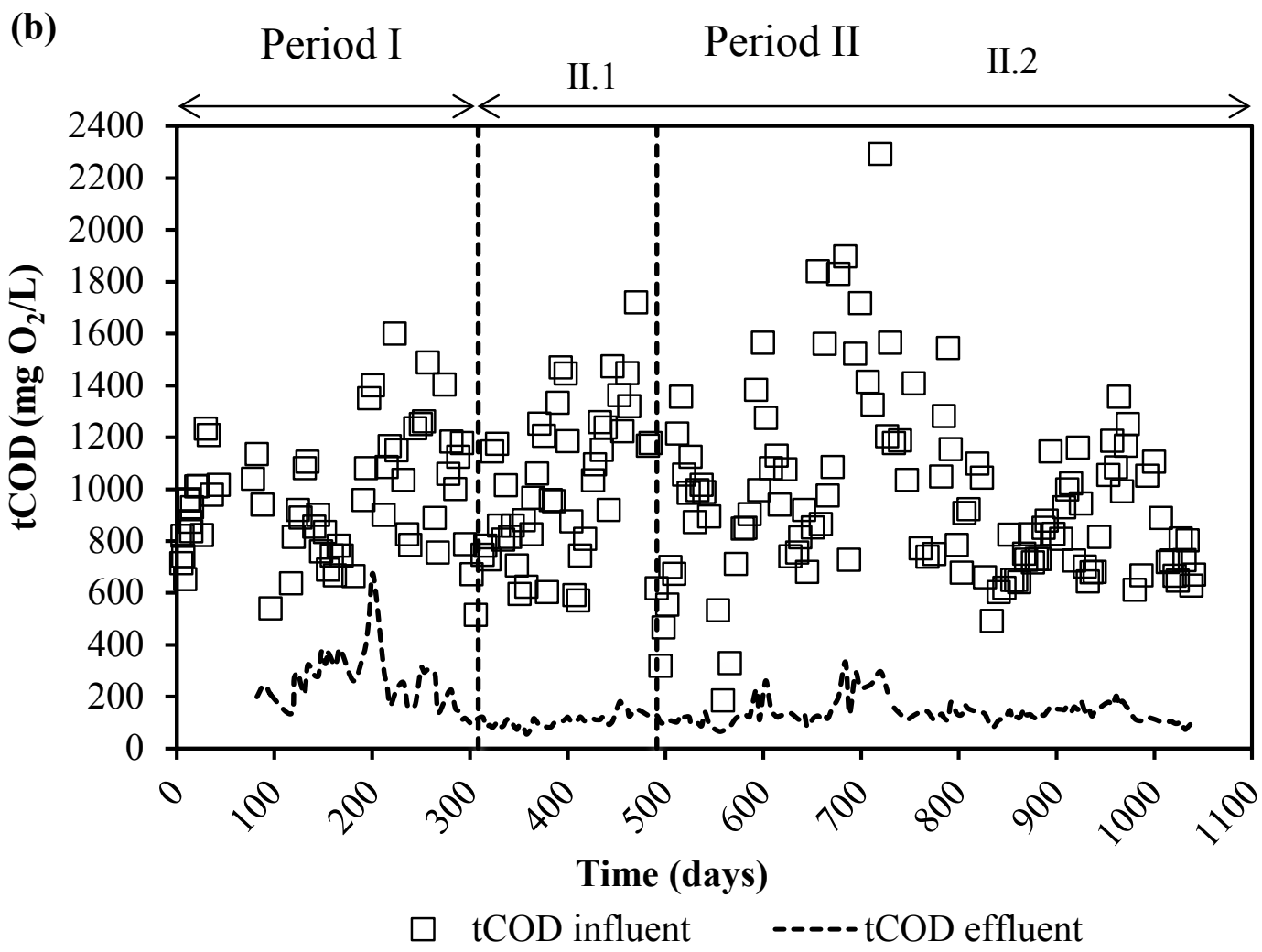

Figure 6.2. (a) Evolution of tCOD removal efficiency of the AnSMBR, VLR ${ }_{U A S B}$ and $\mathrm{HRT}_{\mathrm{UASB}}$. (b) Evolution of tCOD in the influent and effluent of AnSMBR during the period of operation. 


\subsubsection{COD removal efficiency}

Figure 6.2 shows the tCOD removal efficiencies, volumetric loading rate (VLR), HRT and the tCOD of the influent and effluent of the AnSMBR during the operation of the pilot plant. The parameters VLR and HRT are both calculated considering the useful volume of the biological section. Table 6.2 summarizes the average results obtained for pseudo-steady state periods with different HRTs. During the operation without recirculation (Period II.1) the VLR was gradually increased from 1 to $2.4 \mathrm{~kg} \mathrm{tCOD} / \mathrm{m}^{3} \mathrm{~d}$ by decreasing the HRT in the biological section from 20 to $11 \mathrm{~h}$, leading to a decrease in the quality of the effluent from $93.7 \pm 11.2 \mathrm{mg} / \mathrm{L}$ to $147 \pm 17.5 \mathrm{mg} / \mathrm{L}$. The respective $\mathrm{BOD}_{5}$ increased from $30 \mathrm{mg} / \mathrm{L}$ to $75 \pm 5 \mathrm{mg} / \mathrm{L}$.

As can be seen in Table 6.2, the results obtained during the recirculation period (Period II.2) were similar to those obtained during Period II.1. By operating with VLR between $1.84 \pm 0.27 \mathrm{~kg} \mathrm{tCOD} / \mathrm{m}^{3} \mathrm{~d}(\mathrm{HRT}=14 \mathrm{~h})$ and $2.7 \pm 0.85 \mathrm{~kg} \mathrm{tCOD} / \mathrm{m}^{3} \mathrm{~d}(\mathrm{HRT}=10.5 \mathrm{~h})$ the tCOD of the effluent increased from $134 \pm 26 \mathrm{mg} / \mathrm{L}$ to $176 \pm 80 \mathrm{mg} / \mathrm{L}$. When the VLR increased to $3.18 \mathrm{~kg} \mathrm{tCOD} / \mathrm{m}^{3} \mathrm{~d}(\mathrm{HRT}=9.8 \mathrm{~h})$, the tCOD of the effluent increased to $225 \pm 58 \mathrm{mg} / \mathrm{L}$.

The results obtained in this work confirm that the AnSMBR treating municipal wastewater at psychrophilic temperature $\left(18 \pm 2^{\circ} \mathrm{C}\right)$ achieves a removal efficiency of $89.6 \pm 2 \%$, reaching values of the tCOD in the effluent around $120 \mathrm{mg}$ tCOD/L at HRT of $13-14 \mathrm{~h}$ and VLR between $1.5-2 \mathrm{~kg}$ tCOD $/ \mathrm{m}^{3} \mathrm{~d}$. Comparing these results with those obtained in a previous work (Gouveia et al., 2015) with a different AnMBR configuration and fed with identical wastewater but inoculated with flocculent sludge, it was observed that the current work obtained similar percentages of tCOD removal, but operating with higher HRT, between $13-14 \mathrm{~h}$, as opposed to $8-10 \mathrm{~h}$ in the previous work. This difference could be due to the different adaptation and evolution of each inoculum to the psychrophilic conditions. The specific methanogenic activity at $18^{\circ} \mathrm{C}$ of the sludge from the bottom of the UASB reactor was slightly lower in the present work than in the previous work, between $0.04-0.06 \mathrm{~g} \mathrm{COD} / \mathrm{g} \mathrm{VS} \mathrm{d}$ as opposed to $0.05-0.11 \mathrm{~g}$ $\mathrm{COD} / \mathrm{g}$ VS d, respectively. Similar tCOD removal was found in the literature consulted. Dong, (2015), working with a pilot AnMBR fed with sewage from the Burlington Skyway Wastewater Treatment Plant, at $23 \pm 1^{\circ} \mathrm{C}$, with HRT of $8.5 \mathrm{~h}$ and VLR between 0.858-1.09 $\mathrm{kg} \mathrm{tCOD} / \mathrm{m}^{3} \mathrm{~d}$, obtained COD removal efficiencies between $88 \pm 3.9 \%-91.8 \pm 1.9 \%$. Huang et al., (2013) with three submerged anaerobic membrane 
bioreactors (SAnMBRs), at $25-30^{\circ} \mathrm{C}$, VLR of $1.02 \pm 0.14 \mathrm{~kg} \mathrm{tCOD} / \mathrm{m}^{3} \mathrm{~d}$, achieved total COD removal efficiencies of $84 \pm 6 \%, 85 \pm 3 \%, 86 \pm 3 \%$, respectively. Martin-Garcia et al., (2011) working with a granular-AnMBR, HRT of $16 \mathrm{~h}$, VLR of $0.51 \mathrm{~kg} \mathrm{tCOD} / \mathrm{m}^{3} \mathrm{~d}$, upflow velocity of $1 \mathrm{~m} / \mathrm{h}$, and fed with real domestic wastewater and without external temperature control, obtained a similar COD removal of $86 \%$.

VFA in the effluent of the AnSMBR were practically not detected for VLR lower than 1 $\mathrm{kg} C O D / \mathrm{m}^{3} \mathrm{~d}$ and it was around $22 \pm 15.4 \mathrm{mg} / \mathrm{L}$ for VLR between $2-2.2 \mathrm{~kg} \mathrm{COD} / \mathrm{m}^{3} \mathrm{~d}$, operating without recirculation (Period II.1). The VFA composition was acetic, propionic and butyric acid at $56 \pm 35.8 \%, 30.4 \pm 28.4 \%$, and $13.5 \pm 6.8 \%$, respectively. Similar results were observed operating with recirculation. At VLR of $1.84-1.91 \mathrm{~kg}$ $\mathrm{COD} / \mathrm{m}^{3} \mathrm{~d}$, the VFA concentration in the effluent was $29.5 \pm 24.3 \mathrm{mg} / \mathrm{L}$ (composed by acetic and propionic acid at $54 \pm 44.4 \%, 46 \pm 8.1 \%$, respectively). When the VLR increased to $3.18 \mathrm{~kg} \mathrm{COD} / \mathrm{m}^{3} \mathrm{~d}$, the tCOD removal decreased and the VFAs concentration in the effluent increased to values of around $59 \pm 31 \mathrm{mg} / \mathrm{L}$, being mainly composed of acetic acid and propionic acid (49.6 $\pm 27.4 \%, 40.9 \pm 24.8 \%)$. 
Table 6.2. Principal parameters of operation of AnSMBR (average values).

\begin{tabular}{|c|c|c|c|c|c|c|c|}
\hline $\begin{array}{l}\text { Time } \\
\text { (d) }\end{array}$ & $\begin{array}{c}\text { HRT }_{\text {UASB }} \\
\text { (h) }\end{array}$ & $\begin{array}{c}\text { VLR } \\
\left(\mathrm{Kg} \mathrm{tCOD} / \mathrm{m}^{3}{ }_{\text {UASB }} \mathrm{d}\right) \\
\end{array}$ & $\begin{array}{c}\text { F/M } \\
(\mathrm{Kg} \text { tCOD/Kg VS } \\
\text { UASB d })\end{array}$ & $\begin{array}{l}\text { tCOD effluent } \\
(\mathrm{mg} / \mathrm{L})\end{array}$ & $\begin{array}{c}\text { BOD }_{5} \text { effluent } \\
(\mathrm{mg} / \mathrm{L})\end{array}$ & $\begin{array}{c}\mathrm{CH}_{4}^{\mathrm{c}} \\
\left(\mathrm{L} / \mathrm{g} \mathrm{COD}_{\text {fed }}\right) \\
\end{array}$ & $\begin{array}{l}\text { tCOD } \\
\text { efemoval } \\
\text { efficiency }(\%)\end{array}$ \\
\hline $320-344^{\mathrm{a}}$ & 19.9 & $0.97 \pm 0.16$ & $0.060 \pm 0.010$ & $93.7 \pm 11.2$ & n.a. & $0.22 \pm 0.02$ & $89.7 \pm 2.2$ \\
\hline $348-358^{\mathrm{a}}$ & 20.3 & $0.72 \pm 0.11$ & $0.045 \pm 0.007$ & $73.7 \pm 13.8$ & n.a. & $0.19 \pm 0.04$ & $89.2 \pm 2.8$ \\
\hline $411-418^{a}$ & 15.9 & $0.94 \pm 0.19$ & $0.081 \pm 0.016$ & $113 \pm 6.9$ & $34.3 \pm 0.2$ & $0.26 \pm 0.01$ & $83.7 \pm 2.8$ \\
\hline $420-428^{a}$ & 14.2 & $1.56 \pm 0.04$ & $0.134 \pm 0.003$ & $112 \pm 1.5$ & $30 \pm 5$ & $0.22 \pm 0.01$ & $89.5 \pm 0.4$ \\
\hline $470-485^{a}$ & 12.9 & $2.12 \pm 0.43$ & $0.144 \pm 0.028$ & $133 \pm 12.2$ & n.a. & $0.18 \pm 0.01$ & $90.0 \pm 0.9$ \\
\hline $491-509^{\mathbf{b}}$ & 13.1 & $0.88 \pm 0.20$ & $0.058 \pm 0.013$ & $104 \pm 10.5$ & $34.3 \pm 8.4$ & $0.21 \pm 0.02$ & $80.1 \pm 5.5$ \\
\hline $519-545^{b}$ & 13.3 & $1.55 \pm 0.12$ & $0.091 \pm 0.007$ & $105 \pm 18.0$ & $37 \pm 9$ & $0.21 \pm 0.03$ & $89.4 \pm 1.8$ \\
\hline $554-566^{b}$ & 12.0 & $0.60 \pm 0.24$ & $0.035 \pm 0.013$ & $73 \pm 8.5$ & n.a. & $0.19 \pm 0.02$ & $74.9 \pm 9.9$ \\
\hline $699-740^{\mathbf{b}}$ & 9.8 & $3.18 \pm 0.80$ & $0.238 \pm 0.050$ & $225 \pm 58.3$ & $111.8 \pm 52.8$ & $0.18 \pm 0.01$ & $85.3 \pm 2.9$ \\
\hline $761-775^{b}$ & 14.2 & $1.10 \pm 0.02$ & $0.087 \pm 0.002$ & $130 \pm 14.8$ & $46.4 \pm 5.6$ & $0.18 \pm 0.01$ & $82.7 \pm 1.9$ \\
\hline $782-792^{b}$ & 14.2 & $1.84 \pm 0.27$ & $0.145 \pm 0.021$ & $134 \pm 26.6$ & n.a. & $0.14 \pm 0.01$ & $88.9 \pm 3.2$ \\
\hline $803-908^{\mathbf{b}}$ & 15.3 & $1.11 \pm 0.27$ & $0.066 \pm 0.015$ & $132 \pm 18.9$ & $54.2 \pm 5.9$ & $0.19 \pm 0.01$ & $80.9 \pm 1.9$ \\
\hline
\end{tabular}

n.a. - not analysed $\quad{ }^{\mathbf{a}}$ without recirculation (period II.1) $\quad{ }^{\mathbf{b}}$ with recirculation (period II.2) ${ }^{\mathbf{c}}$ produced + desorbed 


\subsubsection{Nitrogen and phosphorus removal}

The $\mathrm{N}-\mathrm{TKN}$ and $\mathrm{N}-\mathrm{NH}_{4}{ }^{+}$were determined in the soluble phase of the influent, at sampling points S.p.2, S.p.3 and at the effluent of the AnSMBR. According to Table 8.1 , most of the $\mathrm{N}-\mathrm{TKN}$ in the influent was present in the form of $\mathrm{N}-\mathrm{NH}_{4}{ }^{+}(80.7 \pm$ $7.2 \%$ of the total $\mathrm{N}-\mathrm{TKN}$ ). There was no significant increase in the concentration of $\mathrm{N}-$ $\mathrm{NH}_{4}{ }^{+}$in the effluent of the AnSMBR as a result of the treatment process $(83.2 \pm 9.0 \%$ of the total N-TKN). Soluble phosphorous concentration underwent a similar trend, with no significant difference between the concentration of $\mathrm{P}$ at the soluble phase of the influent and effluent of the AnSMBR being recorded.

\subsubsection{Biogas}

The biogas composition in Period II.1 and Period II.2, without and with recirculation, respectively is reported in Table 6.3. These results showed that the recirculation had no significant effect on the composition of the biogas. There was no difference either in the hydraulic residence time, as shown in the work of Souza et al., (2011), where a clear increase in the methane composition was obtained by increasing the HRT. The $\mathrm{N}_{2}$ composition was lower compared with the values from the literature. Matsuura et al., (2015) working with an UASB reactor, treating municipal sewage at ambient temperatures $\left(10-28^{\circ} \mathrm{C}\right)$, obtained nitrogen concentrations in biogas of between 25 and $33 \%$.

The dissolved methane was estimated in order to determine the loss of methane in the effluent of the AnSMBR. Table 6.4 summarizes the methane desorbed $\left(\mathrm{mg} \mathrm{CH}_{4} / \mathrm{L}\right.$ of wastewater treated) from the effluent of the AnSMBR (S.p.4) and from the UASB section (S.p.2) together with the percentage of oversaturation. As can be seen in Table 6.4, the mean value of desorbed methane from the biological section (S.p.2) was $39.2 \pm 6.9 \mathrm{mg} \mathrm{CH} / \mathrm{L}$, while from the effluent of the AnSMBR it was $19.1 \pm 0.9 \mathrm{mg}$ $\mathrm{CH}_{4} / \mathrm{L}$. The results showed that the mean value of oversaturation in the UASB (S.p.2) was $109.1 \pm 17.7 \%$, while for the effluent of the AnSMBR it was $15.3 \pm 5.3 \%$. This significant difference could be because of a higher turbulence in the filtration section than in the biological section, due to the biogas sparging which contributes to the desorption of the dissolved methane and decreases the loss of methane in the effluent of the AnSMBR. Giménez et al., (2012) reported that biogas-assisted mixing avoided 
super-saturation and guaranteed the minimum concentration of dissolved methane at the effluent of the AnMBR. Nevertheless, Smith et al., (2015) reported average values of oversaturation of $2.2 \pm 0.74$ when treating domestic wastewater in an AnMBR at $15^{\circ} \mathrm{C}$, and similar results at $12^{\circ} \mathrm{C}$. In addition, significant differences are observed in the dissolved methane at the effluent from the UASB reactors working at psychrophilic conditions. Souza et al., (2011), when working at $25^{\circ} \mathrm{C}$, reported a degree of oversaturation of between 40 and $70 \%$ in the effluent of different UASB reactors. Urban et al., (2007), in a study carried out with municipal wastewater in a UASB pilot plant, obtained values of between 20 and $25 \mathrm{mg} \mathrm{CH}_{4 \text { dissolved }} / \mathrm{L}$ when working at temperatures between $20-25^{\circ} \mathrm{C}$. Matsuura et al., (2015) described a supersaturated effluent in a pilotscale UASB with an average of $13 \%$.

Table 6.3. Biogas composition during Period II.1 and Period II.2.

\begin{tabular}{ccc}
\hline & Period II.1 (\%) & Period II.2 (\%) \\
\hline $\mathbf{C O}_{2}$ & $9-12$ & $5-10$ \\
$\mathbf{H}_{2} \mathrm{~S}$ & $0.2-0.3$ & $0.1-0.3$ \\
$\mathbf{N}_{2}$ & $6-9$ & $7-12$ \\
$\mathrm{CH}_{4}$ & $80-83$ & $81-83$ \\
\hline
\end{tabular}


Table 6.4. Desorbed methane to the gas phase and methane dissolved in the liquid phase after desorption, in samples from the UASB reactor (S.p.2) and from the effluent (S.p.4).

\begin{tabular}{|c|c|c|c|c|c|c|}
\hline \multirow[t]{2}{*}{ Day } & \multicolumn{3}{|c|}{ UASB reactor (S.p.2) } & \multicolumn{3}{|c|}{ Effluent AnSMBR (S.p.4) } \\
\hline & Gas phase & Liquid phase & Oversaturation & Gas phase & Liquid phase & Oversaturation \\
\hline & $\left(\mathrm{mg} \mathrm{CH}_{4} / \mathrm{L}_{\mathrm{H} 2 \mathrm{O}}\right)$ & $\left(\mathrm{mg} \mathrm{CH}_{4} / \mathrm{L}_{\mathrm{H} 2 \mathrm{O}}\right)$ & $(\%)$ & $\left(\mathrm{mg} \mathrm{CH}_{4} / \mathrm{L}_{\mathrm{H} 2 \mathrm{O}}\right)$ & $\left(\mathrm{mg} \mathrm{CH}_{4} / \mathrm{L}_{\mathrm{H} 2 \mathrm{O}}\right)$ & $(\%)$ \\
\hline 517 & $39.4 \pm 1.7$ & $2.71 \pm 0.11$ & $98.5 \pm 8.2$ & n.a. & n.a. & n.a. \\
\hline $\mathbf{5 9 0}$ & $43.7 \pm 1.5$ & $3.53 \pm 0.12$ & $122.7 \pm 7.1$ & n.a. & n.a. & n.a. \\
\hline 609 & $45.2 \pm 1.6$ & $3.47 \pm 0.01$ & $129.5 \pm 7.4$ & $19.4 \pm 1.5$ & $1.53 \pm 0.12$ & $18.1 \pm 8.5$ \\
\hline 624 & $44.7 \pm 1.6$ & $3.43 \pm 0.11$ & $126.9 \pm 7.3$ & $19.5 \pm 1.6$ & $1.45 \pm 0.12$ & $18.2 \pm 8.9$ \\
\hline 723 & $22.8 \pm 1.5$ & $1.90 \pm 0.12$ & $16.5 \pm 7.1$ & $18.9 \pm 1.6$ & $1.42 \pm 0.12$ & $14.6 \pm 9.1$ \\
\hline 855 & $38.0 \pm 1.5$ & $2.83 \pm 0.11$ & $92.5 \pm 7.3$ & $17.2 \pm 1.5$ & $1.32 \pm 0.11$ & $4.5 \pm 8.4$ \\
\hline 881 & $36.2 \pm 1.5$ & $2.80 \pm 0.11$ & $83.9 \pm 7.1$ & n.a. & n.a. & n.a. \\
\hline 939 & $39.4 \pm 1.7$ & $2.65 \pm 0.11$ & $98.3 \pm 8.1$ & $20.1 \pm 1.4$ & $1.65 \pm 0.11$ & $22.7 \pm 7.9$ \\
\hline 1267 & n.a. & n.a. & n.a. & $19.8 \pm 2.9$ & $0.77 \pm 0.11$ & $16.9 \pm 16.3$ \\
\hline
\end{tabular}

n.a. - not analysed 


\subsubsection{Specific methane yield}

The specific methane yield (SMY) was calculated by the ratio between the methane production and the tCOD removed. The tCOD removed was determined by subtracting the tCOD of the influent, and the tCOD of the effluent of the AnSMBR. The methane production was calculated taking into account the methane production measured plus the methane dissolved in the effluent, considering a mean value of $18.8 \pm 1.7 \mathrm{mg} \mathrm{CH} / \mathrm{L}$ of wastewater treated.

No significant difference was observed in the SMY when operating without or with recirculation, the respective values obtained were 0.226 and $0.216 \mathrm{Nm}^{3} \mathrm{CH}_{4} / \mathrm{g}$ tCOD ${ }_{\text {removed. }}$ This would mean that the reactor operating without recirculation appears to be adequately mixed. This slight difference could indicate a good distribution of the accumulated particulate material in the new configuration. The value obtained indicates that around $60 \%$ of the tCOD is biologically removed and around $40 \%$ is accumulated in the system due to the ultrafiltration process, however it is not biodegraded. In a previous work by Gouveia et al., (2015), working with identical wastewater and temperature but with a different membrane configuration, obtained SMY values of $0.187 \mathrm{Nm}^{3} \mathrm{CH}_{4} / \mathrm{g} \mathrm{tCOD}_{\text {removed }}$ without recirculation and $0.235 \mathrm{Nm}^{3} \mathrm{CH}_{4} / \mathrm{g}_{\mathrm{gCOD}}$ removed with recirculation. In both configurations the SMY were below the theoretical value. The SMY value obtained in the current work is similar to that reported in literature. Martinez-Sosa et al., (2012), using an AnSMBR and treating low-strength wastewater under psychrophilic conditions $\left(20^{\circ} \mathrm{C}\right)$, obtained an average SMY of $0.24 \mathrm{Nm}^{3} \mathrm{CH}_{4} / \mathrm{kg}$

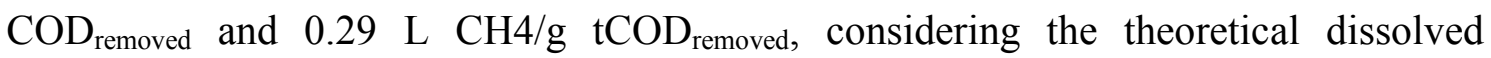
methane. Lin et al., (2011) reported SMY of $0.26 \mathrm{~L} \mathrm{CH}_{4} / \mathrm{g} \mathrm{tCOD}_{\text {removed }}$ by treating domestic wastewater in a submerged anaerobic membrane bioreactor. Gao et al., (2014) obtained a SMY of $0.19 \mathrm{~L} \mathrm{CH}_{4} / \mathrm{g} \mathrm{tCOD}_{\text {removed }}$ working at 35 and $25^{\circ} \mathrm{C}$, and a value of $0.14 \mathrm{~L} \mathrm{CH}_{4} / \mathrm{g} \mathrm{tCOD}_{\text {removed }}$ at $15^{\circ} \mathrm{C}$.

\subsubsection{Accumulation of particulate COD}

Figure 6.3 shows the evolution of the sCOD inside the filtration section (S.p.3) and the tCOD of the effluent (S.p.4). As can be seen, there was a great difference between the tCOD of the effluent and the sCOD inside the filtration section. This difference was due to the ultrafiltration membrane, which fully retained inside the system any particulate/colloidal matter larger than $0.04 \mu \mathrm{m}$. This retention caused the accumulation 
of particulate matter. The accumulated materials were inorganic and organic solids that were non-biodegradable or slowly biodegradable from the wastewater, as well as cellular debris and biological organic material. The municipal wastewater fed to the UASB reactor had a particulate COD content at around $26-48 \%$ of the tCOD. The accumulation rate depends on the particulate material content of the wastewater, its biodegradability, the volumetric loading rate, the purges carried out, the recirculation between the filtration section and the biological section, and the configuration between the membrane and the reactor. As can be seen in Figure 6.3, during the continuous purge, the sCOD inside the filtration section (S.p.3) remained almost constant, while it was seen to increase during the rest of the operating conditions, except in those cases when purges were performed or the feeding pump was stopped due to sewage failures. When operating without recirculation (Period II.1), working at VLRs of between 0.94 and $2.4 \mathrm{~kg} \mathrm{tCOD} / \mathrm{m}^{3}{ }_{\text {UASB }} \mathrm{d}$, an increase of the tCOD accumulation rate was observed in the filtration section of 239 to $702 \mathrm{mg} \mathrm{tCOD} / \mathrm{L} \mathrm{d}$ respectively, while the accumulation rate of the soluble COD was practically constant between $82-126 \mathrm{mg} \mathrm{sCOD} / \mathrm{L} \mathrm{d}$. Nevertheless, operating with recirculation (Period II.2) and working with VLRs of between 1 and $1.55 \mathrm{~kg} \mathrm{tCOD} / \mathrm{m}^{3}$ UASB $\mathrm{d}$, the accumulation rate in the filtration section was between 90-119 $\mathrm{mg}$ tCOD/L $\mathrm{d}$ and the soluble COD was around 14-18 mg/L d. This accumulation effect of particulate/colloidal material caused by the membrane has been reported in recent literature (Gouveia et al., 2015; Bae et al. 2014; Martinez-Sosa et al. 2012).

As previously mentioned, there was no significant effect of the recirculation on the specific methane yield. Nevertheless, the recirculation improved the degree of mixing. As Figure 6.4 shows, tCOD at the filtration section (S.p.3) decreased and remained below the tCOD values of the upper part of the UASB reactor (S.p.2) during the recirculation period, while sCOD remained almost similar during that period in both sections. Comparing this behaviour with that obtained in a previous work (Gouveia et al., 2015), it seems that the new membrane configuration when operating with recirculation allows for a better distribution of the accumulated material through the system. 


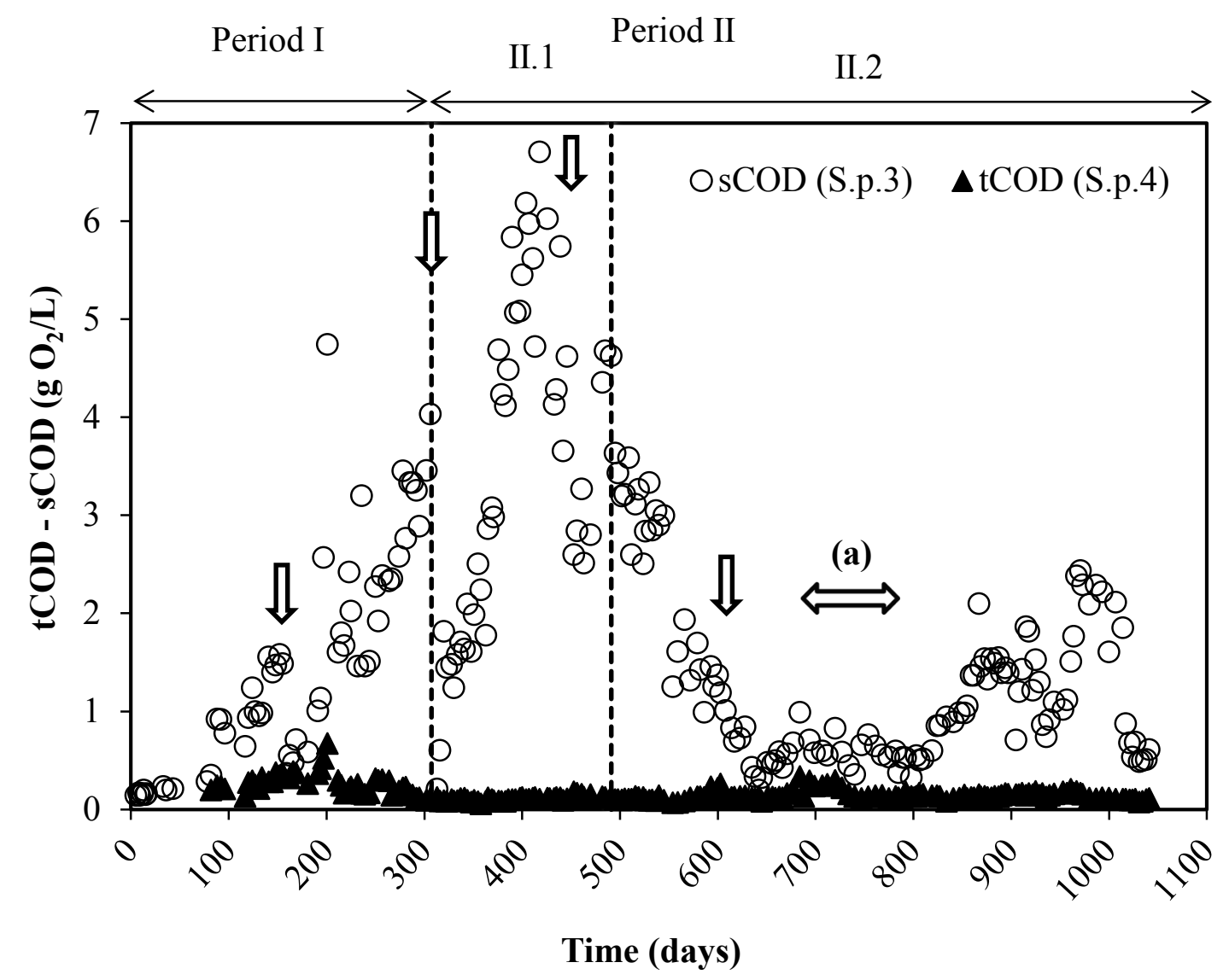

Figure 6.3. Evolution of tCOD of the effluent (S.p.4), sCOD in the filtration section (S.p.3) during the entire period of operation (arrows indicate the purges of accumulated material; (a) - continuous purge). 


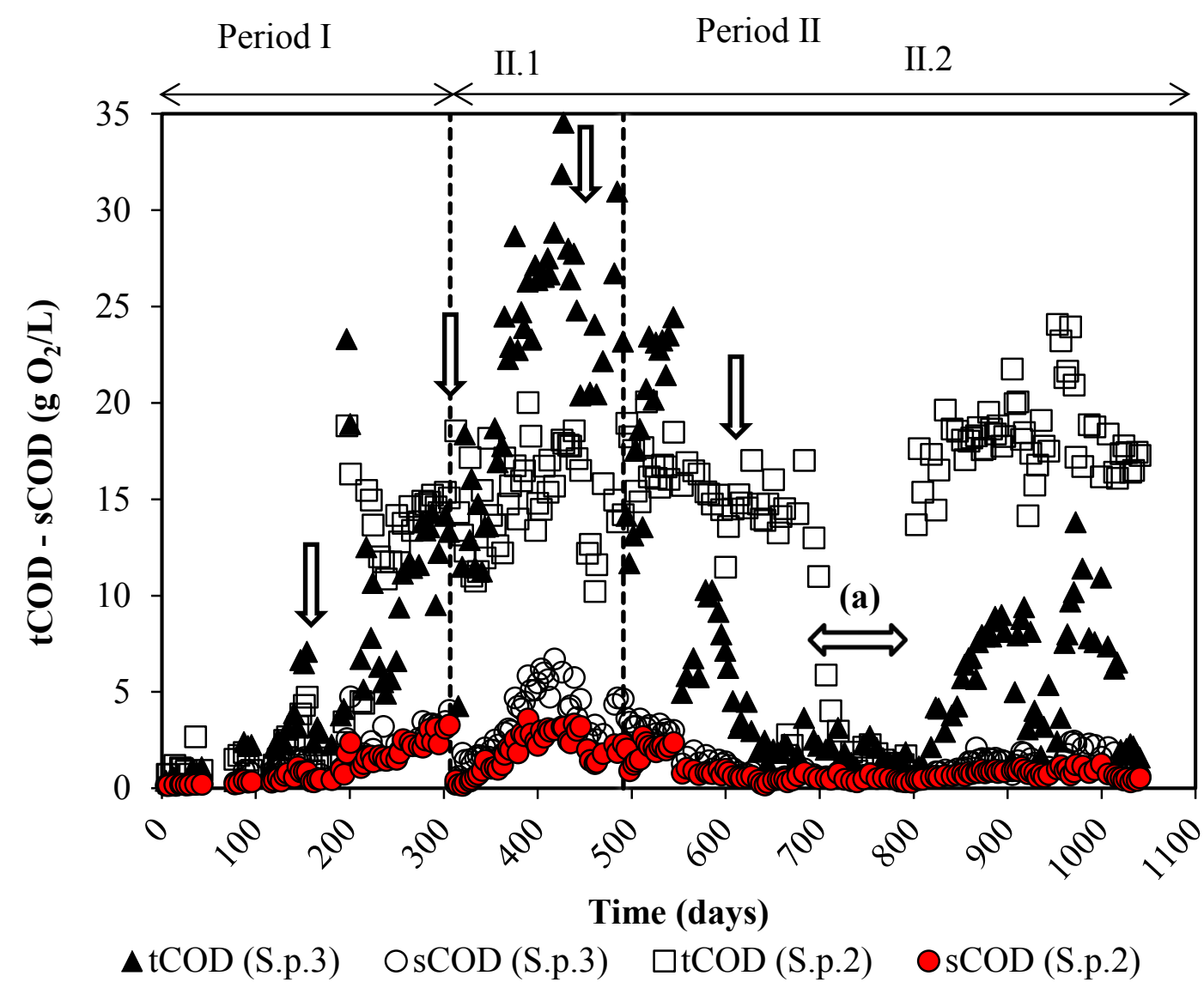

Figure 6.4. Evolution of tCOD, sCOD in the UASB (S.p.2) and filtration section (S.p.3) during the entire period of operation (arrows indicate the purges of accumulated material; (a) continuous purge).

\subsubsection{Biosolids production}

The VS concentration was measured in the biological section (S.p.0, 1 and 2) and in the filtration section (S.p.3 and 5). In the biological section, the VS concentration was maintained between $58.3 \pm 2.3 \mathrm{~g} \mathrm{VS} / \mathrm{L}, 55.5 \pm 7.8 \mathrm{~g} \mathrm{VS} / \mathrm{L}$ and $6.5 \pm 3.5 \mathrm{~g} \mathrm{VS} / \mathrm{L}$, respectively. No degranulation or loss of granular sludge integrity was observed throughout the operation. Taking into account the volume of each zone, the amount of VS in the biological section was maintained between $4.5 \mathrm{~kg}$ and $5.7 \mathrm{~kg}$ throughout the whole operation of the pilot plant. No biomass wastage of the biological section was carried out, except for the samples taken to monitor the process. However, in the filtration section, four periodical purges were carried out approximately every 150 days, and a continuous purge from day 684 to day 792. Table 6.5 summarizes the purges carried out throughout the operation. The biosolid production (BS) was calculated 
taking into account the volume removed from the filtration section $\left(\mathrm{V}_{\text {purged }}\right)$ and the concentration of VS contained therein (g VS/L) at the moment of the purge, considering the following equations:

$\mathrm{WFR}=\frac{\mathrm{V}_{\text {purged }}}{\text { days between purges }}$

$\operatorname{MFR}=\frac{\mathrm{V}_{\text {purged }} *[\mathrm{VS}]}{\text { days between purges }}$

$\mathrm{BS}=\frac{\mathrm{MFR}}{[\mathrm{tCOD} \text { removed } / \mathrm{d}]}$

$\mathrm{WR}=\frac{\mathrm{WFR}}{\mathrm{Q}_{\text {fed }}} * 100$

where WFR is the wasting flow rate (L/d), MFR is the mass flow rate of volatile solids wasted (g VS/d), BS is the biosolid production ( $\left.\mathrm{g} \mathrm{VS}_{\text {wasted }} / \mathrm{g} \mathrm{tCOD}_{\text {removed }}\right)$, WR is the wasting ratio (\%) and $\mathrm{Q}_{\text {fed }}$ the flow rate of wastewater fed to the UASB reactor $(\mathrm{L} / \mathrm{d})$.

As shown in Table 6.5, the purges were carried out with different VS concentrations in the filtration section, and different volumes. Under these conditions, the biosolid

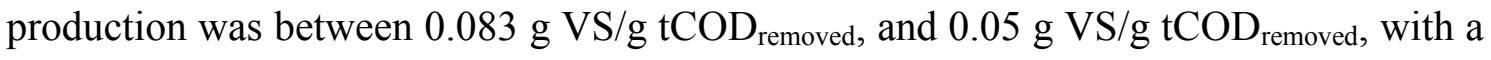
wasting ratio between 1.1 and $0.3 \%$ respectively. The lower biosolid production from the purge on day 609 was due to the lower concentration of VS in the filtration section, caused by the recirculation from the filtration section to the bottom of the biological section. During the continuous purge, even when operating with a wasting ratio of $3 \%$, the biosolid production was around $0.03 \mathrm{~g} \mathrm{VS} / \mathrm{g}$ tCOD ${ }_{\text {removed }}$ due to the low solid concentration in the filtration section, lower than $1 \mathrm{~g} \mathrm{VS} / \mathrm{L}$.

The results obtained in the present work were similar to those reported in the literature. Shin et al., (2014) in a pilot scale anaerobic fluidized membrane bioreactor (AFMBR) working without temperature control $\left(9-30^{\circ} \mathrm{C}\right)$, obtained an average biosolid production of $0.051 \mathrm{~g} \mathrm{VSS} / \mathrm{g} \mathrm{COD}_{\text {removed }}$ with a wasting ratio of $1 \%$. Bae et al., (2014), using 
synthetic wastewater at $25^{\circ} \mathrm{C}$ in an AFMBR, obtained a sludge production of $0.003 \mathrm{~g}$ $\mathrm{VSS} / \mathrm{g} \mathrm{COD}_{\text {removed }}$ with a wasting ratio between $0.8-0.5 \%$. Nevertheless, Pretel et al.,( 2014), working with an AnMBR, treating sulphate-rich urban wastewater, obtained low/moderate sludge production of $0.16,0.43$ and $0.55 \mathrm{Kg} \mathrm{TSS} / \mathrm{Kg} \mathrm{COD}$ removed at 35, 22 , and $17^{\circ} \mathrm{C}$, respectively. Wei et al., (2014) reported a biomass yield between 0.015 and $0.026 \mathrm{~g}$ MLVSS/g COD working at mesophilic conditions with synthetic municipal wastewater.

Biochemical methane potential tests of the biosolids wasted in the current work were conducted under mesophilic conditions $\left(35^{\circ} \mathrm{C}\right)$ in order to determine the mesophilic anaerobic biodegradability. The BMP tests showed that the biodegradability was between 28 and 42\%, with specific methane production at day 16 of between 123 and $327 \mathrm{~mL} \mathrm{CH}_{4} / \mathrm{g} \mathrm{VS}_{\text {fed. }}$. 
Table 6.5. Purges carried out from the filtration section (S.p.3) of the AnSMBR.

\begin{tabular}{lcccccc}
\hline & & \multicolumn{5}{c}{ AnSMBR } \\
\hline days & & $\mathbf{1 5 6}$ & $\mathbf{3 0 7}$ & $\mathbf{4 4 8}$ & $\mathbf{6 0 9}$ & $\mathbf{6 8 4 - 7 9 2}$ \\
$\mathbf{V}_{\text {purged }}$ & $(\mathrm{L})$ & 425.32 & 380 & 160 & 160 & 1964.32 \\
VS & $(\mathrm{g} / \mathrm{L})$ & 7.44 & 7.16 & 16.08 & 2.28 & 0.89 \\
VS & $(\mathrm{g})$ & 3162.5 & 2720.8 & 2571.2 & 364.8 & 1748.4 \\
Wasting flow rate & $(\mathrm{L} / \mathrm{d})$ & 2.73 & 2.52 & 1.13 & 0.99 & 18.19 \\
Mass VS wasted & $(\mathrm{g} \mathrm{VS} / \mathrm{d})$ & 20.27 & 18.02 & 18.24 & 2.27 & 16.19 \\
Biosolids production & $(\mathrm{g} \mathrm{VS} / \mathrm{g} \mathrm{COD}$ removed $)$ & 0.067 & 0.083 & 0.050 & 0.004 & 0.026 \\
Wasting ratio & $(\%)$ & 0.59 & 1.07 & 0.30 & 0.18 & 3.03 \\
Recirculation & & no & no & no & yes & yes \\
\hline
\end{tabular}

(a) continuous purge from day 684 until day 792 . 


\subsubsection{Membrane behavior}

Figure 6.5 illustrates the performance of the membrane throughout the experimental period of the AnSMBR pilot plant. Biogas sparging, and the above mentioned purges, were the parameters modified to control TMP. Biogas was continuously sparged at the bottom of the hollow fibers, with different flow rates. A superficial biogas velocity of 9 $\mathrm{m} / \mathrm{h}$ was enough to maintain a low increase in TMP over approximately the first 400 days of operation due to the low solid concentration and low permeate flux. When the flux was gradually increased from $8 \mathrm{~L} / \mathrm{m}^{2} \mathrm{~h}$ to $15 \mathrm{~L} / \mathrm{m}^{2} \mathrm{~h}$, together with a high solid concentration in the filtration section, a remarkable increase in TMP was originated. In order to maintain the filtration pressure, the biogas superficial velocity was increased up to $16 \mathrm{~m} / \mathrm{h}$ and the filtration time was simultaneously decreased from 15 to 7.5 minutes, and the back-flush from 1 to 0.5 minutes. Moreover on day 448 and on day 609 two purges were carried out, and on day 493 the mixed liquid from the filtration section was recirculated to the bottom of the UASB in order to decrease the solid concentration. The recirculation and periodical purges permitted the maintenance of a low concentration of solids in the filtration section and, therefore, a high permeate flux and a moderate increase in the TMP. During this stage the flux was maintained between $14-15 \mathrm{~L} / \mathrm{m}^{2} \mathrm{~h}$ and the TMP was kept at around 300-350 mbar. The decrease of superficial biogas velocity to $12 \mathrm{~m} / \mathrm{h}$ and to $9 \mathrm{~m} / \mathrm{h}$, after 725 days of continuous operation, caused a significant increase in TMP, even when the permeate flux was gradually decreased from $15 \mathrm{~L} / \mathrm{m}^{2} \mathrm{~h}$ to $12 \mathrm{~L} / \mathrm{m}^{2} \mathrm{~h}$. Under these conditions, the TMP increased up to $570 \mathrm{mbar}$, although the concentration of solids in the filtration section was lower than $2 \mathrm{~g} / \mathrm{L}$. The increase, once again, of the biogas velocity to $16 \mathrm{~m} / \mathrm{h}$, caused a pressure recovery from 590 mbar to 350 mbar. As can be seen in Figure 5, the change of the superficial biogas velocity has a significant effect on the pressure filtration. When the permeate flux was decreased a great deal due to occasional operational problems, the TMP decreased, but returned quickly to the initial level after restarting. The results obtained show that the main parameters involved in the fouling of the membrane were the permeate flux, the superficial velocity of biogas and the solid concentration, which depends on the recirculation rate and periodical purges carried out. Defining the fouling rate as the daily increase of the TMP, a fouling rate of between 1-3 mbar/d was obtained with high biogas sparging $(16 \mathrm{~m} / \mathrm{h})$, high permeate flux $\left(12 \mathrm{~L} / \mathrm{m}^{2} \mathrm{~h}\right)$ and a solid concentration lower than $2 \mathrm{~g} \mathrm{VS} / \mathrm{L}$. Meanwhile, the fouling rate increased up to $19 \mathrm{mbar} / \mathrm{d}$ when the 
permeate flux increased to $15.7 \mathrm{~L} / \mathrm{m}^{2} \mathrm{~h}$ and the solid concentration to $12-14 \mathrm{~g} \mathrm{VS} / \mathrm{L}$. Martinez-Sosa et al., (2011), working with an AnSMBR at $20^{\circ} \mathrm{C}$ and flux constant of 7 $\mathrm{L} / \mathrm{m}^{2} \mathrm{~h}$, reported an increase on TMP of $2.61 \mathrm{mbar} / \mathrm{d}$.

In the present work, the membrane operated for most of the time with a flow rate around 12-14 L/m $\mathrm{m}^{2} \mathrm{~h}$ with transmembrane pressure between 350-600 mbar. During the three years of continuous operation, the membrane was not physically or chemically cleaned. The different membrane behavior observed in the current work and the previous work (Gouveia et al., 2015) could be due to the combination of three factors: the different membrane configuration (which allowed better solid circulation from the membrane section to the UASB reactor), the higher biosolid wasted in the current work, and the lower superficial velocity of the biogas sparging applied. In both configurations, the specific gas demand was between $0.5-1 \mathrm{~m}^{3} / \mathrm{m}^{2} \mathrm{~h}$, nevertheless the biogas superficial velocity was different. In the previous work, biogas velocity ranged between 30-60 $\mathrm{m} / \mathrm{h}$, and in the current work the biogas superficial velocity was between $9-16 \mathrm{~m} / \mathrm{h}$. Continuous biogas sparging is needed in the filtration section, and the superficial biogas velocity is a fundamental parameter for controlling TMP increase. Nevertheless, a high superficial velocity does not improve the fouling rate in long-term operation. Li et al., (2014), working with a submerged Anammox membrane bioreactor at $35.0 \pm 0.5^{\circ} \mathrm{C}$, using synthetic wastewater, reported a flux between 7.08 to $14.16 \mathrm{~L} / \mathrm{m}^{2} \mathrm{~h}$, with a volatile suspended solid concentration of $3 \mathrm{~g} / \mathrm{L}$ and biogas sparging between 0 and $0.2 \mathrm{~m}^{3} / \mathrm{h}$, with periodic removal for chemical cleaning. Bae et al., (2014) working with synthetic wastewater at $25^{\circ} \mathrm{C}$ in an anaerobic fluidized membrane bioreactor, using a PVDF membrane with a pore size of $0.1 \mu \mathrm{m}$, reported a flux between 6 and $9 \mathrm{~L} / \mathrm{m}^{2} \mathrm{~h}$. Robles et al., (2013), working with a SAnMBR plant, reported that a biogas sparging of around $0.23 \mathrm{Nm}^{3} / \mathrm{m}^{2} \mathrm{~h}$ was enough to operate for two and a half years with a flux of $8 \mathrm{~L} / \mathrm{m}^{2} \mathrm{~h}$. Meanwhile, Fox and Stuckey, (2015), working with AnMBR, fed with synthetic wastewater, reported that biogas sparging reduced fouling substantially, using a critical flux of $11.8 \mathrm{~L} / \mathrm{m}^{2} \mathrm{~h}$ and a sparging rate of $6 \mathrm{~L} / \mathrm{min}$. 


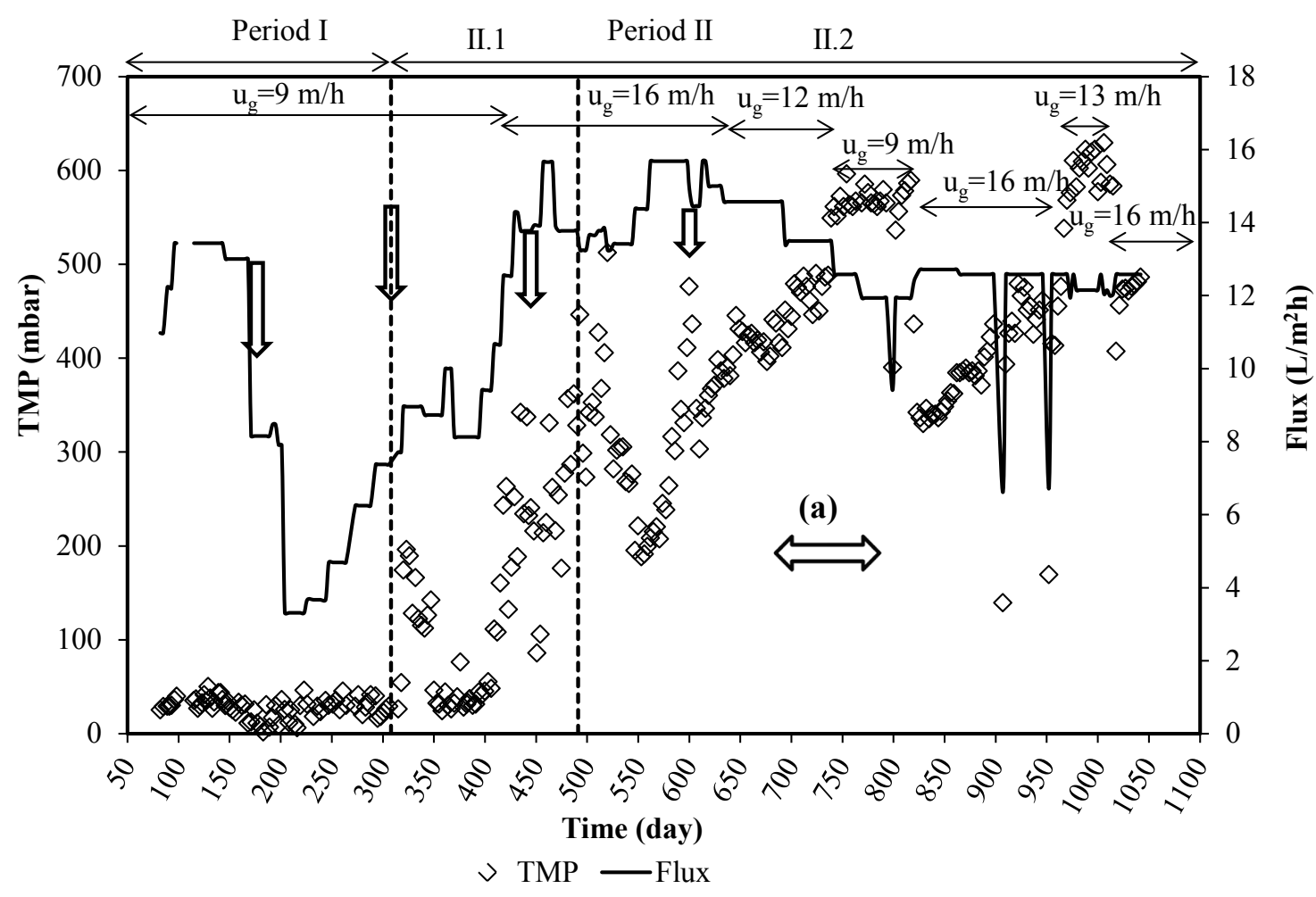

Figure 6.5. Evolution of TMP and permeate flux during the entire period of operation (arrows indicate the purges of accumulated material; (a) continuous purge).

\subsection{Conclusions}

The results show the reliability and stability of AnSMBR technology for the treatment of municipal wastewater at psychrophilic conditions. The membrane configuration, placed on top of the UASB reactor, together with a superficial biogas velocity of between $16-9 \mathrm{~m} / \mathrm{h}$, allows the continuous operation of the membrane for three years without physical or chemical cleaning, operating with a permeate flux between 14-12 $\mathrm{L} / \mathrm{m}^{2} \mathrm{~h}$. The solid concentration in the filtration section, controlled by recirculation from the filtration section to the UASB reactor and by periodical purges every 150 days, has been a fundamental parameter for the long-term stability of the technology. 


\subsection{Acknowledgements}

This work was part of the project IPT-2011-1078-310000 led by CADAGUA and supported by the Spanish Ministry of Environment. The ultrafiltration membrane module (ZW-10 Zenon) was supplied by General Electric. The Environmental Technology group of the Valladolid University is a member of the Consolider-Novedar programme and "Grupo de Excelencia" from the Regional Government of Castilla y León (GR 76). 


\subsection{References}

APHA., AWWA. and WPCF., 2005. Standard Methods for the Examination of Water and Wastewater, 21st ed. American Public Health Association, Washington DC. USA.

Bae, J., Shin, C., Lee, E., Kim, J., McCarty, P.L., 2014. Anaerobic treatment of lowstrength wastewater: A comparison between single and staged anaerobic fluidized bed membrane bioreactors. Bioresour. Technol. 165, 75-80.

Bialek, K., Cysneiros, D., Flaherty, V.O., 2014. Hydrolysis, acidification and methanogenesis during low-temperature anaerobic digestion of dilute dairy wastewater in an inverted fluidised bioreactor. Environ. Biotechnol. 8737-8750.

Bowen, E.J., Dolfing, J., Davenport, R.J., Read, F.L., Curtis, T.P., 2014. Lowtemperature limitation of bioreactor sludge in anaerobic treatment of domestic wastewater. Water Sci. Technol. 69, 1004-1013.

Dong, Q., 2015. Characterization of Anaerobic Membrane Bioreactors (AnMBR ) Treating Municipal Wastewater. Waterloo, Ontario, Canada.

Fox, R.A., Stuckey, D.C., 2015. The effect of sparging rate on transmembrane pressure and critical fl ux in an AnMBR. J. Environ. Manage. 151, 280-285.

Gao, D.-W., Hu, Q., Yao, C., Ren, N.-Q., 2014. Treatment of domestic wastewater by an integrated anaerobic fluidized-bed membrane bioreactor under moderate to low temperature conditions. Bioresour. Technol. 159, 193-198.

Giménez, J.B., Martí, N., Ferrer, J., Seco, A., 2012. Methane recovery efficiency in a submerged anaerobic membrane bioreactor (SAnMBR) treating sulphate-rich urban wastewater: evaluation of methane losses with the effluent. Bioresour. Technol. 118, 67-72. 
Gouveia, J., Plaza, F., Garralon, G., Fdz-Polanco, F., Peña, M., 2015. Long-term operation of a pilot scale anaerobic membrane bioreactor (AnMBR) for the treatment of municipal wastewater under psychrophilic conditions. Bioresour. Technol. 185, 225-233.

Huang, Z., Ong, S.L., Ng, H.Y., 2013. Performance of submerged anaerobic membrane bioreactor at different SRTs for domestic wastewater treatment. J. Biotechnol. 164, $82-90$.

Judd, S., 2006. The MBR Book Principles and Applications of Membrane Bioreactors for Water and Wastewater Treatment, 1st ed. Elsevier B.V.

Lew, B., Tarre, S., Beliavski, M., Dosoretz, C., Green, M., 2009. Anaerobic membrane bioreactor (AnMBR) for domestic wastewater treatment. Desalination 243, 251257.

Li, Z., Xu, X., Xu, X., Yang, F., Zhang, S., 2014. Sustainable operation of submerged Anammox membrane bioreactor with recycling biogas sparging for alleviating membrane fouling. Chemosphere 140, 106-113.

Lin, H., Chen, J., Wang, F., Ding, L., Hong, H., 2011. Feasibility evaluation of submerged anaerobic membrane bioreactor for municipal secondary wastewater treatment. Desalination 280, 120-126.

Lin, H., Peng, W., Zhang, M., Chen, J., Hong, H., Zhang, Y., 2013. A review on anaerobic membrane bioreactors: Applications, membrane fouling and future perspectives. Desalination 314, 169-188.

Martinez-Sosa, D., Helmreich, B., Horn, H., 2012. Anaerobic submerged membrane bioreactor (AnSMBR) treating low-strength wastewater under psychrophilic temperature conditions. Process Biochem. 47, 792-798.

Martinez-Sosa, D., Helmreich, B., Netter, T., Paris, S., Bischof, F., Horn, H., 2011. Anaerobic submerged membrane bioreactor (AnSMBR) for municipal wastewater treatment under mesophilic and psychrophilic temperature conditions. Bioresour. Technol. 102, 10377-10385. 
Martin-Garcia, I., Monsalvo, V., Pidou, M., Le-Clech, P., Judd, S.J., McAdam, E.J., Jefferson, B., 2011. Impact of membrane configuration on fouling in anaerobic membrane bioreactors. J. Memb. Sci. 382, 41-49.

Matsuura, N., Hatamoto, M., Sumino, H., Syutsubo, K., Yamaguchi, T., Ohashi, A., 2015. Recovery and biological oxidation of dissolved methane in effluent from UASB treatment of municipal sewage using a two-stage closed downflow hanging sponge system. J. Environ. Manage. 151, 200-209.

McKeown, R.M., Scully, C., Mahony, T., Collins, G., O’Flaherty, V., 2009. Long-term (1,243 days), low-temperature (4-15 degrees C), anaerobic biotreatment of acidified wastewaters: bioprocess performance and physiological characteristics. Water Res. 43, 1611-1620.

Metcalf \&Eddy, W.E.T. and R., 2003. Metcalf \&Eddy, 4th ed. McGraw Hill.

Ozgun, H., Kaan, R., Evren, M., Kinaci, C., Spanjers, H., Lier, J.B. Van, 2013. A review of anaerobic membrane bioreactors for municipal wastewater treatment: Integration options, limitations and expectations. Sep. Purif. Technol. 118, 89-104.

Pretel, R., Robles, A., Ruano, M. V, Seco, A., Ferrer, J., 2014. The operating cost of an anaerobic membrane bioreactor (AnMBR) treating sulphate-rich urban wastewater. Sep. Purif. Technol. 126, 30-38.

Robles, A., Ruano, M.V., Ribes, J., Ferrer, J., 2013. Advanced control system for optimal filtration in submerged anaerobic MBRs (SAnMBRs). J. Memb. Sci. 430, $330-341$.

Shin, C., Mccarty, P.L., Kim, J., Bae, J., 2014. Pilot-scale temperate-climate treatment of domestic wastewater with a staged anaerobic fluidized membrane bioreactor (SAF-MBR). Bioresour. Technol. 159, 95-103.

Skouteris, G., Hermosilla, D., López, P., Negro, C., Blanco, Á., 2012. Anaerobic membrane bioreactors for wastewater treatment: A review. Chem. Eng. J. 198$199,138-148$. 
Smith, A.L., Skerlos, S.J., Raskin, L., 2015. Anaerobic membrane bioreactor treatment of domestic wastewater at psychrophilic temperatures ranging from $15^{\circ} \mathrm{C}$ to $3^{\circ} \mathrm{C}$. Environ. Sci. Water Res. Technol. 1, 56-64.

Smith, A.L., Skerlos, S.J., Raskin, L., 2013. Psychrophilic anaerobic membrane bioreactor treatment of domestic wastewater. Water Res. 47, 1655-1665.

Smith, A.L., Stadler, L.B., Love, N.G., Skerlos, S.J., Raskin, L., 2012. Perspectives on anaerobic membrane bioreactor treatment of domestic wastewater: a critical review. Bioresour. Technol. 122, 149-159.

Souza, C.L., Chernicharo, C. a L., Aquino, S.F., 2011. Quantification of dissolved methane in UASB reactors treating domestic wastewater under different operating conditions. Water Sci. Technol. 64, 2259-2264.

Urban, I., Weichgrebe, D., Rosenwinkel, K.-H., 2007. Anaerobic treatment of municipal wastewater using the UASB-technology. Water Sci. Technol. 56, 37-44.

Van Lier, J.B., Tilche, A., Ahring, B. K., Macarie, H., Moletta, R., Dohanyos, M., Pol, L.W., Lens, P., Verstraete, W., 2001. New perspectives in anaerobic digestion. Water Sci. Technol. 43, 1-18.

Wei, C.-H., Harb, M., Amy, G., Hong, P.-Y., Leiknes, T., 2014. Sustainable organic loading rate and energy recovery potential of mesophilic anaerobic membrane bioreactor for municipal wastewater treatment. Bioresour. Technol. 166, 326-334. 


\section{CHAPTER 7}

Membrane cleaning 



\subsection{Fundamentals of Membrane fouling}

One of the most frustrating issues in MBR application is membrane fouling, which causes a significant reduction in the flux, membrane efficiency, and membrane replacement period, and increases the operation costs. Several attempts have been made to reduce membrane fouling in MBR technologies from chemical/physical membrane cleanings to the applications of transverse vibration and media fluidization on membrane surface (Ngo et al., 2008; Kola et al., 2014; Aslam et al., 2014).

Membrane fouling is closely related to particle deposition on the membrane surface that forms a cake layer, to a great extent reversible fouling, and colloidal and soluble matter deposited at the entrance or inside the membrane pores, and to a great extent irreversible fouling (Charfi and Amar, 2012; Meng et al., 2009).

The configuration of submerged hollow-fiber membrane modules determines fouling distribution. The non-uniform distribution of the permeate flow between individual fibers in the fiber bundle and along each one is a consequence of the following factors: dead zones surrounding the two headers; high membrane density and non-uniformity of fiber packing which has a direct impact on clogging and bubble-induced shear distribution; and fiber tightness that affects fiber movement (Braak et al., 2011). Irregular distribution of local fluxes results not only in changes in local permeability and in the fouling rate at the different regions of the membrane module and along the fiber (Li et al., 2014), but also in the physical and chemical cleaning efficiencies. The development of a fouling minimization strategy needs to identify where the fouling is located. The in-series resistance model is widely used to describe fouling behavior, but different resistance components are identified according to the experimental methods employed to estimate the contribution of each one (Khalili-garakani et al., 2011; Sarioglu et al., 2012). The differences in filtration and backwash resistance can be employed to distinguish between external and internal fouling (Jeison and van Lier, 2006).

\subsubsection{Overview of membrane fouling}

Membrane flux in MBRs can be affected by concentration polarization (CP), external fouling, and internal fouling according to its locations relative to the membrane structure (Castaing et al., 2011; El Rayess et al., 2012; Judd, 2011). 
- Concentration polarization. Concentration polarization is defined as an accumulation of solutes or particles in a thin liquid layer adjacent to the membrane surface (Bhattacharjee et al., 1999; Porter, 1972; Zhao et al., 2000), which is an inherent phenomenon of membrane filtration.

- External fouling. The deposition of particles, colloids and macromolecules on the membrane surfaces leads to external fouling. It is also termed 'fouling layer' on membrane surfaces. In general, external fouling can be divided into two kinds of fouling layers: cake layer due to the accumulation of retained solids on the membrane, and gel layer resulted from the precipitation of soluble macromolecules, colloids, and inorganic solutes (Van den Brink et al., 2013; Wang et al., 2012; Wang and Waite, 2009).

- Internal fouling. Internal fouling is caused by the adsorption and deposition of solutes and fine particles within the internal structure of membranes, e.g., adsorption of foulants to pore-walls and pore narrowing or blocking (El Rayess et al., 2012; Giraldo et al., 2006; Le-Clech et al., 2006).

As been said previously, membrane fouling can be classified into biofouling, organic fouling and inorganic fouling based on the biological and chemical characteristics of membrane foulants.

According to Wang et al., (2014), the biological, organic and inorganic nature of membrane foulants determines the selection of membrane cleaners, which can have significant influences on membrane cleaning efficiency. In the Fig. 7.1, the same author says that the following four types of fouling (reversible, irreversible, residual and irrecoverable fouling) can be defined based on the attachment strength of fouling materials to the membranes or the method used to recover the initial permeability of the membranes.

- Reversible fouling. Reversible fouling results from the loose attachment of fouling materials to membrane surfaces, which can be removed by physical cleaning method, e.g., relaxation, a strong shear force or backflush. It is also termed 'removable' or 'temporary' fouling (Judd, 2011; Meng et al., 2009). 
- Irreversible fouling. Formation of a strong matrix of fouling layer with solutes during a continuous filtration will result in reversible fouling being transformed into an irreversible fouling layer, e.g., formation of gel layer under long-term sub-critical flux operation (Wang et al., 2008).

- Residual fouling. Residual fouling cannot be removed by chemically enhanced backflush or maintenance cleaning but can be removed by recovery cleaning. This concept was proposed by Judd, (2011) and Kraume et al., (2009).

- Irrecoverable fouling. Once a membrane is fouled during long-term operation, the original virgin membrane permeability is never recovered. There is a remaining resistance which can be defined as 'irrecoverable fouling', and it is not readily removed by typical chemical cleaning (Judd, 2011; Resosudarmo et al., 2013). It is also referred to as 'permanent fouling' or 'long-term irreversible fouling', which builds up over a number of years and might ultimately determine membrane life (Ayala et al., 2011).

\subsection{Overview of membrane cleaning}

Membrane cleaning is typically classified into in-situ and ex-situ cleaning based on membrane modules within membrane bioreactor or out of bioreactor during cleaning. It is also categorized into physical, chemical and biological/biochemical cleaning according to fouling removal mechanisms or cleaning agents used.

\subsubsection{In-situ and ex-situ cleaning}

Membrane cleaning can be classified into 'in-situ' (online cleaning) and 'ex-situ' cleaning [offline cleaning or cleaning out of place (COP)]. The membrane modules remain inside the membrane bioreactor during in-situ cleaning, and are placed in another tank during the ex-situ cleaning, In the Fig. 7.1 are summarizes the protocols of 'in-situ' and 'ex-situ' cleaning adapted in MBRs.

As shown in Figure 7.1. there are some series of cleaning methods belong to in-situ membrane cleaning, e.g., intermittent filtration (relaxation), online ultrasonication, particle or suspended carrier scouring, backflush, biological/biochemical cleaning, chemically enhanced backflush (CEB), maintenance cleaning or termed CIP, cleaning in 
air (CIA) and also recovery (intensive) cleaning. Ex-situ cleaning requires the removal of membrane modules from membrane tank, and physical cleaning combined with chemical cleaning can be carried out (Fig. 7.1).

In-situ cleaning is preferred in MBRs during operation compared to ex-situ membrane cleaning. In-situ cleaning is performed more frequently than ex-situ cleaning. The time interval for ex-situ cleaning is typically once every 1-3 years, while in-situ cleaning can be carried out every $10 \mathrm{~min}$, or weeks, or several months dependent on membrane fouling conditions and cleaning strategies used.

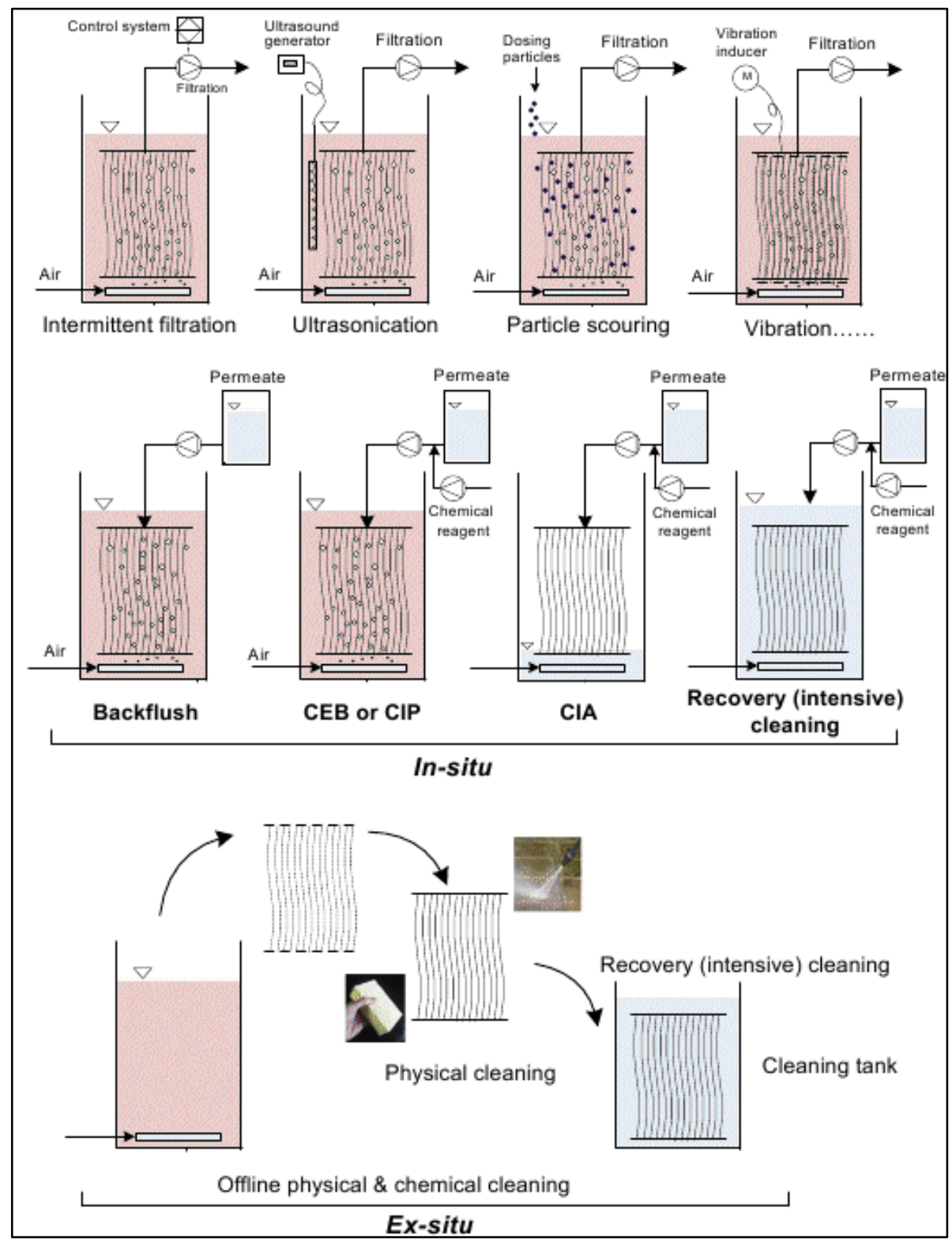

Figure 7.1. In-situ and ex-situ cleaning of membranes. CEB: chemically enhanced backwash; CIP: cleaning-in-place; CIA: cleaning in air (in the drained membrane tank) (Wang et al., 2014). 


\subsubsection{Physical, chemical, and biological cleaning}

1. Physical cleaning is normally and widely achieved either by backflushing, i.e., reversing the flow, or relaxation, which is simply ceasing permeation whilst continuing to scour the membrane with air bubbles (Judd, 2011). Some authores like Kobayashi et al., (2003); Van den Brink et al., (2013); Yang Q. et al., (2006) and Yang X. et al., (2013) proposed a series of other strategies, for instance, online ultra-sonication, mechanical cleaning, adding suspended particles and carriers and vibration, respectively, performed in situ (Fig. 7.2). In general, physical cleaning, which is adopted to remove reversible fouling (e.g., deposited biosolids and cake layer), is less effective compared to chemical cleaning. However, it requires no chemical reagents, and thus is less likely to cause membrane degradation/damage except for some harsh mechanical cleaning.

The physical cleaning can be categorized into hydraulic, mechanical, ultrasonic and other cleaning.

\section{Hydraulic cleaning}

Is a widely-used approach for eliminating reversible fouling in MBRs, includes air scouring, backflushing and relaxation (intermittent filtration) for in-situ membrane cleaning in submerged MBRs (Huang and Wen, 2012).

- Air scouring or aeration is a widely used method for membrane cleaning. The cross flow velocity or shear stress induced by aeration can eliminate $\mathrm{CP}$ and/or remove reversible fouling (Qin et al., 2010; Ratkovich et al., 2009; Xia et al., 2013).

- The principal parameters for backflushing using permeate are backflush flux, duration, and frequency (Hwang et al., 2009; Raffin et al., 2012). According to Wang et al., (2014), some authors have reported in the literature, some data, which are optimum values for the frequencies of backwashing, and can be divided into two groups, i.e., less frequent and longer backflushing (7-16 min filtration/30-60 s backwashing), and more frequent and shorter backflushing (512 min filtration/5-20 s backwashing) for HF and MT membranes. An optimal 
backwashing frequency and duration is dependent on operational parameters (permeate flux, temperature, etc.), foulant properties and backwashing flux.

- In-situ relaxation allows diffusive back transport of membrane foulants away from the membrane surface driven by a concentration gradient, and often is associated with air scouring to enhance the diffusion. It has been well recognized that the intermittent filtration mode (filtration coupled with relaxation) can suppress membrane fouling, which has been incorporated in most MBR designs as standard operating strategies for enhancing membrane performance (LeClech et al., 2006; Wu et al., 2008). The filtration/relaxation durations in AeMBRs and AnMBRs are diversified.

In AeMBRs relaxation is commonly performed for 1-2 min every 7-15 min of filtration for both HF and FS membranes (Huang and Wen, 2012; Judd, 2011), whereas in the AnMBRs, there appears to be a tendency that more frequent relaxation is generally used, e.g., 4-10 min filtration followed by $0.5-2 \mathrm{~min}$ relaxation. It might be attributed to the distinct fouling behaviors between AeMBR and AnMBR. Although the membrane used in AeMBRs can be generally used in AnMBRs, the sludge suspension in AnMBRs is different from that in AeMBRs, which may result in varied fouling properties (Liao et al., 2006; Lin et al., 2013).

\section{Mechanical cleaning}

The mechanisms of mechanical cleaning by adding particles and carriers are as follows (Huang et al., 2008; Rosenberger et al., 2011; Yang Q. et al., 2006; Zhong et al., 2007): (1) the suspended particles/carriers mechanically scour the membrane surface; (2) the turbulence induced by the suspended particles/carriers can enhance the foulant back-transport away from the membrane surface; (3) the suspended particles/carriers vibrate HF membranes; (4) Some polymeric substances and/or fine colloids can be absorbed by the suspended particles/carriers. In general, the first three mechanisms play a dominant role in membrane cleaning. 
Vibration and rotation of membranes can generate high shear or turbulence at the membrane surface, which can realize on-line cleaning of membranes (Beier et al., 2006; Kimura et al., 2000; Low et al., 2009; Prip Beier and Jonsson, 2009). Currently, the reported vibration systems include the Vibratory Shear Enhanced Process (VSEP) and Vibrating Hollow Fiber Modules (VHFM) (Bilad et al., 2012; Low et al., 2005).

In the VHFM systems, the membrane is vibrated by a separated vibrating engine that produces axial oscillations and the membrane and engine are connected via a sliding rod (Bilad et al., 2012). Meanwhile, Lowa et al., (2004), says that the VSEP system filters streams containing a variety of contaminants without the fouling exhibited by traditional membrane systems. The main reason why VSEP can outperform traditional crossflow membrane separation is that the VSEP system is able to prevent foulants from accumulating on the membrane surface.

Other mechanical cleaning is the scraping. This method consists in using a spatula to scarp the fouling layer off the membrane. The harsh mechanical cleaning (offline) could remove fouling layers off the membrane, but the permeate side was found to be covered with bacteria, protozoa and extracellular polymeric substances (EPS) (Van den Brink et al., 2013).

\section{Ultrasonic cleaning}

Ultrasonication has been used for membrane cleaning in various membrane filtration processes (Chai et al., 1999; Xu et al., 2013). Ultrasonic cleaning is effective in alleviating the concentration polarization and removing cake layers on the membrane (Ahmad et al., 2012). Recent study has also shown that on-line ultrasonication can also, to some extent, control gel layer fouling in an AnMBR for sludge digestion (Xu et al., 2013). Ultrasonic cleaning can be performed either in situ or ex situ (Lim and Bai, 2003; Sui et al., 2008). There are several key parameters influencing cleaning efficiencies, e.g., ultrasonic frequency, power density, and duration.

2. Chemical cleaning is defined as to remove irreversible fouling by using chemical reagents and can be generally classified into four categories, such as bases (caustic soda), acids (hydrochloric, sulfuric, citric, oxalic, etc.), oxidants (hypochlorite and hydrogen peroxide), and other chemicals (chelating agents, surfactants, etc.) (Liu et al., 2001). As shown in Fig. 7.1, chemical cleaning can have several protocols based on the 
cleaning process, i.e., in-situ maintenance cleaning and in-situ recovery (intensive) cleaning. In-situ maintenance cleaning includes: CIP, i.e., cleaning membrane in situ without draining the membrane tank; CIA, which is to clean membrane with the membrane tank drained. Recovery cleaning, allowing the membranes to be soaked in cleaning reagent with higher concentration in the drained membrane tank (Fig. 7.1), can be conducted either in situ (in-situ recovery cleaning) or ex situ during offline cleaning of membranes. In addition, chemical agents can also be used together with other physical means to enhance its effectiveness or to reduce the chemical loading. The major mechanisms of various chemical cleaning processes are summarized in Fig. 7.2.

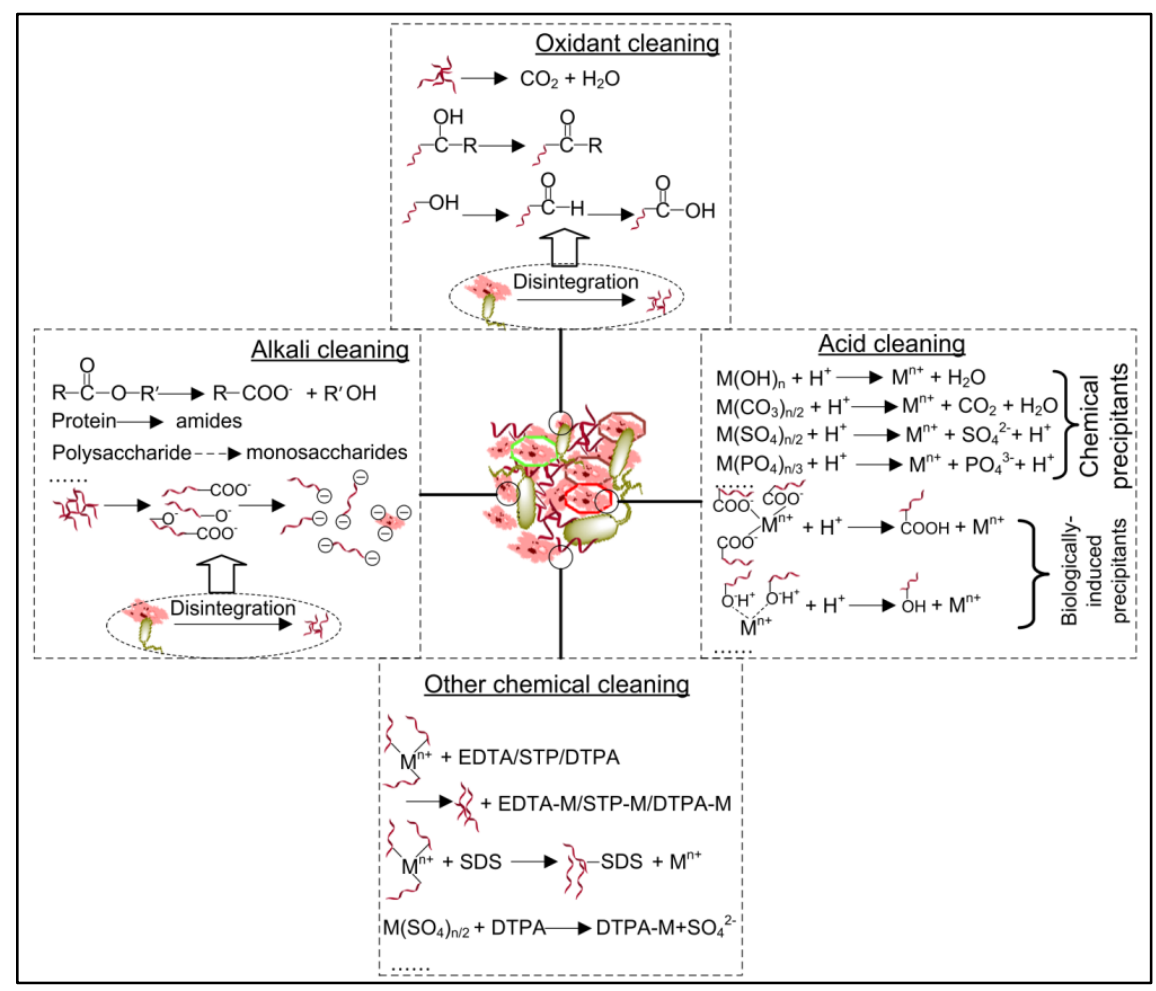

Figure 7.2. Mechanisms of chemical cleaning using acids, bases, oxidants and other chemicals. The binding sites shown are only for ilustration purposes. Symbols: microbes (biomass); $*$ colloids; $\sim$ solutes. DTPA: ethylenetrinitrilopentaacetic acid; EDTA: ethylene diamine tetraacetic acid; SDS: sodium dodecyl sulfate; STP: sodium tripolyphosphate (Wang et al., 2014). 


\section{Acids}

Acid cleaning is targeted to eliminate inorganic fouling (crystals), which are caused by chemical precipitation of inorganic matters (multivalent cations) and biologicallyinduced mineralization between biopolymer and salts. As shown in Fig. 7.2, neutralization and double decomposition reactions are the key mechanisms for removing the chemical and biologically-induced precipitants on membrane surfaces. For instance, iron oxides precipitates can be dissolved through the above-mentioned reactions in the presence of acids. The widely-used acids include oxalic, citric, nitric, hydrochloric, phosphoric, and sulfuric acids. It is worth noting that citric acid/oxalic acid can also form complexes with metal ions (e.g., iron) during membrane cleaning besides neutralization and double decomposition. In some circumstances, citric acid can offer a better cleaning efficiency than other chemical reagents.

\section{Bases}

Alkaline cleaning can remove organic foulants deposited on membrane surfaces. $\mathrm{NaOH}$ is widely used as the cleaning reagent. At caustic conditions, large organic particles such as colloids and microbes can be disintegrated into fine particles and/or soluble organic matters. Organic matters, such as proteins and carbohydrates, can be hydrolyzed and solubilized into small molecules as illustrated in Fig. 7.2. Fats and oils can also react with bases through saponification, generating water-soluble soap micelles. At $\mathrm{pH}$ 11, the functional groups of organic foulants are deprotonated and therefore, the foulants are negatively charged. The repulsive interaction among the foulants within the fouling layer coupled with the cross flow velocity (CFV) induced by aeration is enough to loosen the fouling layer and to transport the foulants from the membrane surface to the bulk solution. It has been reported that $\mathrm{NaOH}$ is more effective in removing proteinrelated foulants compared to carbohydrates.

\section{Oxidants and disinfectants}

Oxidants aim to remove organic and biological foulants through oxidation and/or disinfection. The commonly-used oxidants are $\mathrm{NaClO}$ and hydrogen peroxide $\left(\mathrm{H}_{2} \mathrm{O}_{2}\right)$ for membrane cleaning, while other kinds of oxidants have been also used, e.g., polyvinyl pyrrolidone (PVP) -iodine, peracetic acid and sodium perborate. The major 
mechanisms of oxidant cleaning, as shown in Fig. 7.2, are to disinfect the membranes and to oxidize the functional groups of organic foulants to ketonic, aldehydic, and carboxylic groups. The presence of these functional groups increases the hydrophilicity of their parent compounds, reducing the adhesion of foulants to membranes. Oxidants can also disintegrate the colloids and microbe flocs into fine particles and soluble organic matters, facilitating their further oxidation process.

\section{Other chemicals}

Other chemical reagents used for membrane cleaning include metal chelating chemicals [citric acid as documented earlier EDTA, sodium tripolyphosphate (STP), and diethylenetrinitrilopenta acetic acid (DTPA)], surfactants [sodium dodecyl sulfate (SDS)], and other detergents. Metal chelating agents can form a strong complex with metal ions. As illustrated in Fig. 7.2, biopolymers originally associated with metal ions are replaced by metal chelating agents via a ligand exchange reaction, releasing the biopolymers to their original loose conformation. The surfactants and related detergents, which have both hydrophilic and hydrophobic structures, exhibit amphiphilic characteristics. They are known to solubilize macromolecules since they can form micelles with fat, oil, and proteins in water and help to clean membranes fouled by these materials. The surfactant molecules can absorb organic foulants through hydrophobic tails and break up organic foulant-metal ion bindings through hydrophilic interaction between hydrophilic heads and water molecules. Some commercialized detergents/reagents for membrane cleaning are also developed and can utilize the advantages of various cleaning reagents, and thus improve membrane cleaning efficiencies.

3. Biological cleaning can be broadly designated as the use of cleaning mixtures which contain bioactive agents (enzymes) to enhance removal membrane foulants (Maartens et al., 1996; Muñoz-Aguado et al., 1996; Zhao et al., 2000). Enzymes play a critical role in organic degradation and transformation processes (Chen and Columbia, 2011). Enzymes are selective catalysts, designed for specific targets and offer the advantages over traditional caustic or acid cleaning regimes of being biodegradable and posing fewer pollution problems (D’Souza and Mawson, 2005; Shi et al., 2014). 


\subsubsection{Cleaning protocols}

There are several cleaning protocols which are used in the cleaning of the membranes. Some are used continuously, such as physico-chemical and maintenance cleaning (CIP), for the maintenance operation of the membrane and other cleaning methods are carried out at each time period, when the membrane permeability is not recovered, like recovery cleaning $(\mathrm{COP})$.

The physico-chemical cleaning methods use physical cleaning methods with the addition of chemical agents to enhance cleaning effectiveness. The typical physicochemical cleaning method used in MBRs is CEB by adding a lower concentration of chemical cleaning agent to the backflush water. CEB is periodically carried out if normal physical cleaning (e.g., backflushing) cannot effectively recover membrane permeability (Buzatu et al., 2012).

The concentration of chemical reagents used in CEB is generally lower than that of maintenance and recovery cleaning and can be carried out daily or up every 7-14 d (Wang et al., 2014). According to Gabarrón et al., (2013), the typical concentration for CEB using sodium hypochlorite is in the range of 100-500 mg/L. Meanwhile, Zsirai et al., (2012), reports that sometimes, higher concentration cleaning reagents are also adopted in CEB, e.g., 1000-3000 mg/L NaClO solution. The simultaneous use of ultrasound during chemical cleaning is another physico-chemical cleaning example. Some results indicate that the simultaneous combination of physical and chemical cleaning is a powerful way to enhance membrane cleaning efficiency.

Maintenance cleaning is conducted in situ and is used to maintain membrane permeability and helps reduce the frequency of recovery cleaning and cleaning out place. It is performed either with the membrane in situ, a normal CIP.

Maintenance cleaning, usually taking 30-60 minutes for a complete cycle, is normally carried out every 3-120 d, with a mean value of $28 \mathrm{~d}$ days at moderate reagent concentrations of 300-2000 mg/L NaOCI and 0.2-1.5 wt\% for acid citric. Membrane cleaning studies on anaerobic systems have generally indicated that a combination of caustic and acid washes are required to remove organic and inorganic (namely struvite) foulants from organic anMBR membranes. 
Maintenance cleaning, if employed, adds insignificantly to downtime. It is evident that maintenance cleaning adopts moderate chemical concentrations compared to recovery cleaning (Judd, 2011; Wang et al., 2014).

Recovery cleaning or COP is generally carried out when further filtration is no longer sustainable due to an increase of TMP and consequently a decrease in the permeability (Le-Clech et al., 2006).

Wang et al., (2014), reported that the recovery cleaning is mainlay conducted once or twice a year, when compared with the maintenance cleaning is much longer, and the cleaning recipes of reagents are similar to maintenance cleaning, being the most popular the combination of $\mathrm{NaClO}$ and citric acid cleaning although other cleaning schemes such as $\mathrm{H}_{2} \mathrm{SO}_{4} / \mathrm{NaOH}, \mathrm{NaClO} /$ oxalic acid, $\mathrm{NaClO} / \mathrm{HCl}$, and $\mathrm{H}_{2} \mathrm{O}_{2} /$ citric acid are also used. The concentrations of $\mathrm{NaClO}$ and citric acid used are between $500-3000 \mathrm{mg} / \mathrm{L}$ and $0.4-2 \mathrm{wt} \%$, respectively.

The use combined of cleaning reagents are used in order to enhance membrane cleaning efficiency, cleaning reagents are often jointly or sequentially used. For instance, combination of oxidants and bases can significantly increase relative flux to $150 \%$ compared to $400 \mathrm{ppm} \mathrm{NaClO}$ alone $(60 \%)$ and $0.1 \mathrm{M} \mathrm{NaOH}$ alone $(<10 \%)$. The use of oxidants can form more ketonic, aldehydic, and carboxylic groups in organic foulants, and they can be further deprotonated at a caustic environment to allow the foulants all negatively charged. Through the combined mechanisms, foulants can be well removed from the membrane surface/membrane pores.

Oxidants and acids are also combined in membrane cleaning. Oxidants can remove organic foulants, while use of acids ensures the relatively complete dissolution of inorganic or organic-inorganic complexes. It has to be mentioned that in different MBRs membrane fouling may be different. For achieving a better cleaning efficiency, experiments should be carried out to determine an optimized combination of cleaning reagents for specific membrane cleaning conditions. Some cleaning parameters, like cleaning frequency, duration (downtime), reagent concentration, cleaning protocols (CIP, CIA or COP) and cleaning temperature can impact the cleaning process and permeability recovery rate. 


\subsection{Objectives}

The aim of this chapter was to determine the effectiveness of various methods of physical and chemical cleaning of the membrane. The cleaning efficiency was expressed in terms of permeability and membrane resistance, after every cleaning type. This study was conducted with the membrane of the AnMBR pilot plant and with the membranes of the AnSMBR plant once dismantled the installation.

\subsection{Material and Methods}

\subsubsection{Cleaning methods}

The cleaning methods used in this chapter are described in the seccion 3.5.

\subsubsection{Membrane Resistance $\left(R_{\underline{M}}\right)$ and Permeability (Perm) determination}

Membrane resistance was determined by recording the TMP at increasing flux steps. For this purpose, membrane module was extracted from the reactor, and submerged in tap water. The membrane module was temporarily stopped during resistance and membrane permeability determination. Flux steps for membrane resistance determination were 5, 10, 15 and $20 \mathrm{~L} / \mathrm{m}^{2} \mathrm{~h}$. Membrane permeability is evaluated as the slope of the applied flux $(\mathrm{J})$ at each step versus the mean TMP. Membrane resistance is correlated to the permeability:

$\mathrm{R}_{\mathrm{M}}=\frac{\mathrm{TMP}}{\mathrm{J} \eta}=\frac{1}{\operatorname{Perm} \mu}$

Perm $=\frac{\mathrm{J}}{\mathrm{TMP}}$

where $(\mu)$ represents the permeate viscosity. The membrane was simply rinsed with clean water prior to resistance determination. Then the measured resistance represents the sum of the resistance of the membrane itself, plus the resistance due to fouling and stable cake formation, i.e. the one that cannot be easely reverted by back-flush cycles. This resistance is therefore referred to as apparent membrane resistance (Jeison and van Lier, 2007). 


\subsubsection{General description of the cleaning procedures in the AnMBR}

The physical and chemical cleaning procedures were used to reduce filtration TMP, and to recovery the membrane resistance and the permeability in both pilot plants. The procedures were described below.

During the continuous operation of the AnMBR pilot plant and in order to maintain stable operation of the membrane, the hydraulic physical cleaning by means filtration and backwash cycles and continuous biogas sparging were used. However, as a consequence of membrane fouling it has been necessary every so often (approximately every 6 months) chemical cleaning of the membrane ex situ.

Every time the membrane was removed for chemical cleaning, physical cleaning by applying water jets with tap water was done. Before and after each physical and chemical cleaning the membrane was characterized, in order to determine the resistance and permeability of the membrane.

The membrane was chemically cleaned seven times, througthout the period of operation. The chemical cleaning was carried out submerging the membrane in a PVC tube with a total volume of $25 \mathrm{~L}$ (useful volume $16 \mathrm{~L}$ for chemical cleaning) with a solution of $\mathrm{NaClO}(1000 \mathrm{ppm})$ for between $4-6 \mathrm{~h}$ at $18 \pm 2^{\circ} \mathrm{C}$. With the aim of intensifying the cleaning, cycles of filtration and backwash to extend the contact period of the cleaning solution with the membrane were used.

In order to improve the permeability of the membrane, after the basic chemical cleaned, also acid cleaned had been carried out. A solution of $\mathrm{HCl}$ with a concentration of $1 \mathrm{~g} / \mathrm{L}$, during 2 hours and a temperature of $18 \pm 2^{\circ} \mathrm{C}$ was used. During the cleaning protocol the cycle of filtration and backwash used in the filtration process was maintained.

\subsubsection{General description of the cleaning procedures in the AnSMBR pilot plant}

After three years of operation, without any external physical/chemical cleaning, with a filtration cycle of $7.5 \mathrm{~min}$ ( $91.8 \%$ of the total cycle time), a backwash of $30 \mathrm{~s} \mathrm{(6.1 \%} \mathrm{of}$ the total cycle time) and a relaxation cycle of $10 \mathrm{~s}(2.0 \%$ of the total cycle time), the membranes were extracted from the reactor and proceeds to the physical and differents chemical cleaning protocol. Physical cleaning by applying water jets with tap water was undertaken. After each physical or chemical cleaning protocol, each membrane has been 
characterized with tap water at constant temperature $\left(18 \pm 2^{\circ} \mathrm{C}\right)$ in order to evaluate the resistence and permeability of the membranes and the cleaning efficiency.

The chemical cleaning, of the membranes were carried out ex situ with different reagents, submerging the membrane in a tank with a volume of solution of $16 \mathrm{~L}$.

Afther the physical cleaning the membrane 1 and 2 were submerged in a solution of $\mathrm{NaClO}(1000 \mathrm{ppm})$ during $4 \mathrm{~h}$, first at a temperature of $18 \pm 2^{\circ} \mathrm{C}$, without continuous air sparging. After the characterization the membrane 1 was again cleaned with $1000 \mathrm{ppm}$ $\mathrm{NaClO}$ solution at $40^{\circ} \mathrm{C}$ during $4 \mathrm{~h}$, with continuous air sparging at a superficial velocity of $60 \mathrm{~m} / \mathrm{h}$.

After the basic cleaning, successive acid cleanings were done. Firstly, by cleaning with citric acid $(1 \mathrm{~g} / \mathrm{L})$ during $2 \mathrm{~h}$ at $40^{\circ} \mathrm{C}$. Subsequently, a cleaning with $\mathrm{HCl}(1 \mathrm{~g} / \mathrm{L})$ at $40^{\circ} \mathrm{C}$ during 2 hours was done. Finally a cleaning with $1 \mathrm{w} \%$ EDTA during $2 \mathrm{~h}$ at $40^{\circ} \mathrm{C}$ was done. In all acid cleanings, the membrane filtration cycle and bubbling air at a speed of $60 \mathrm{~m} / \mathrm{h}$ were been used.

The membrane 2 follows the same procedures as the membrane 1, but until the oxidant cleaning at $18 \pm 2^{\circ} \mathrm{C}$, without continous air sparging. After each cleaning, the characterization of the membrane was done, and the resistance and permeability of the memnrane were calculated

According to Jeison and van Lier, (2007), the cleaning efficiency is defined as the percentage of reduction of resistance in relation to the new membrane resistance, and it is evaluated as follows:

Cleaning Efficiency $=\frac{\mathrm{R}_{\text {before }}-\mathrm{R}_{\text {after }}}{\mathrm{R}_{\text {before }}-\mathrm{R}_{\text {new }}} * 100$

where $R_{\text {before, }} R_{\text {after }}$ and $R_{\text {new }}$ represent the resistance before the cleaning, after the cleaning and of the new membrane, respectively.

\subsection{Results and Discussion}

\subsubsection{Physical and chemical cleaning in the AnMBR}

During the entire period of operation of this pilot plant the membrane was physically washing ex-situ 9 times, and chemically 6 times. The results shown the effectiveness obtained in each cleaning, through the membrane resistance and permeability. 
Different cleaning processes mean that efficiency depends on the magnitude and type of fouling. The results shown below were affected by the different states of the module. During the cleaning procedures, air recirculation to improve the cleanliness was not used to avoid foaming due to the release of cleaning reagents into the water. The membrane resistance was determined from TMP monitoring versus the applied flux after taking out the membrane module.

\section{- Physical cleaning ex-situ on day 337 of operation}

As shown in fig. 7.3, there was a small increase on membrane fouling during the first 337 days, in spite of the low concentration of solids and superficial velocity of biogas in the membrane tank. In the bulk solution there was an increase of the resistance of 4.4 times with respect to the new membrane. The physical cleaning reached an cleaning efficiency of $30.2 \%$. 

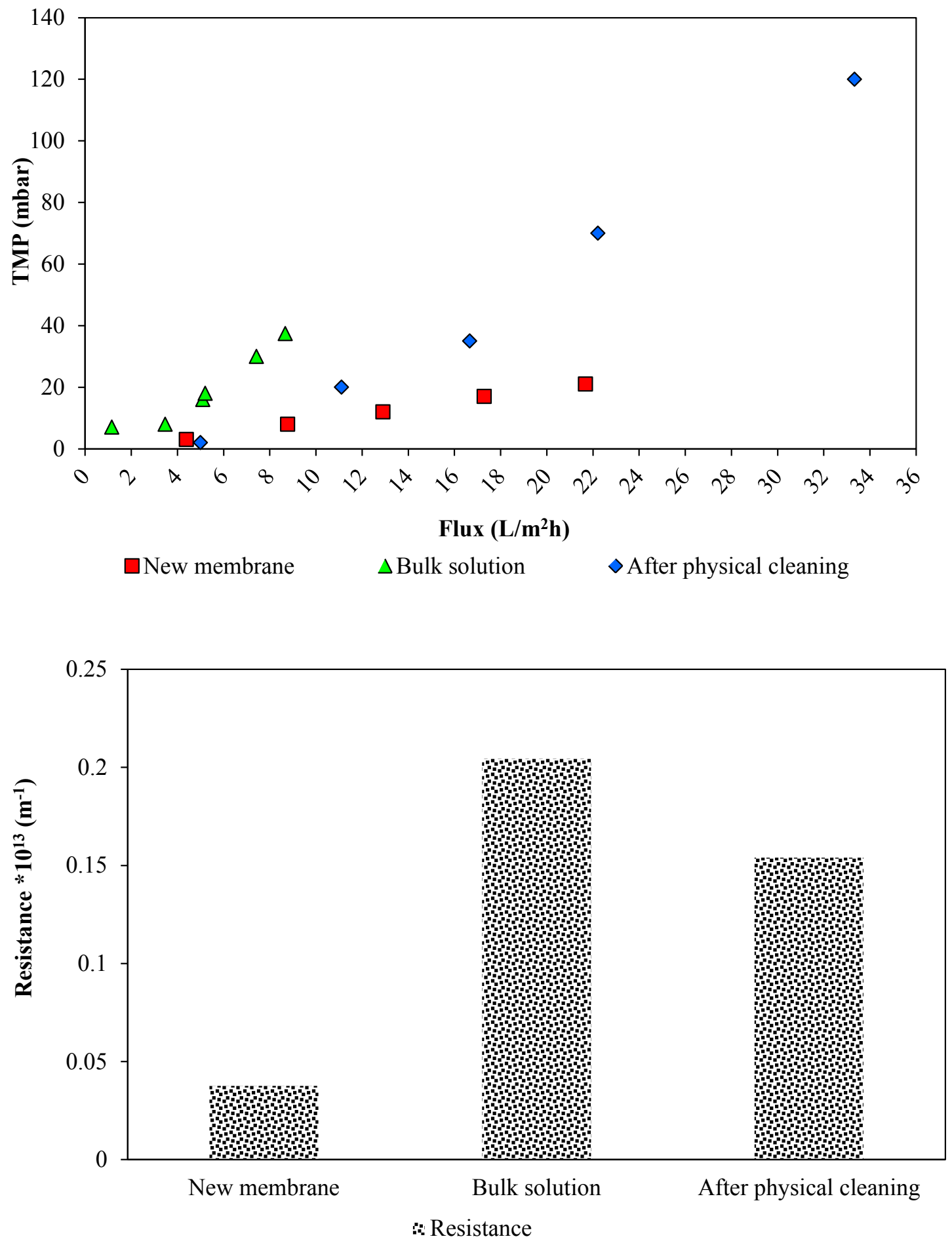

Figure 7.3. Filtration resistance of the membrane in water at $18 \pm 2^{\circ} \mathrm{C}$, in bulk solution of S.p.6 and after the physical cleaning on day 337. 
Meanwhile, in fig. 7.4 after taking out the membrane from the filtration unit a yellowish mucous layer was observed due to anomalous operation of biogas, blocking some fiber entrances.
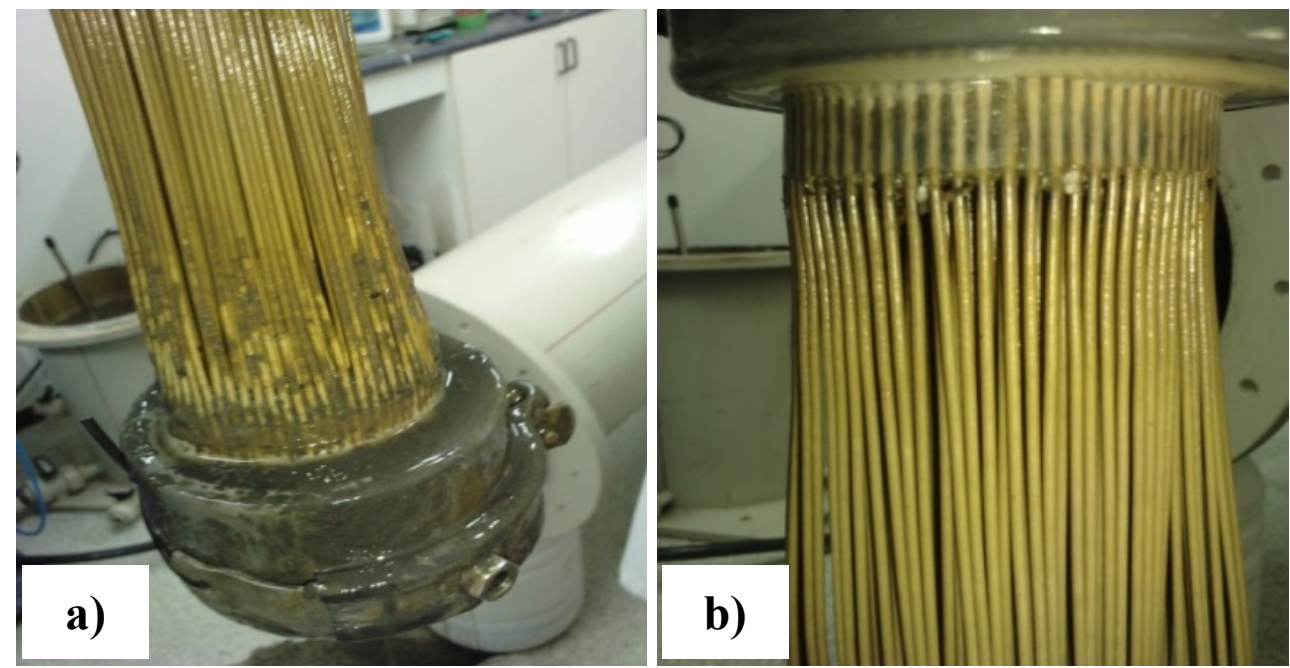

Figure 7.4. Physical appearance of the membrane module throughout the cleaning processes on day 337: a) Bulk solution b) After physical cleaning.

\section{- Physical cleaning ex-situ on day 462 of operation}

Fig. 7.5 shows the behavior of the membrane along the cleaning procedure carried out on day 462 of opration. The greatest resistance to filtration is due to the cake and reversible fouling. Due to the suspension inside the membrane tank, the resistance increase 45.6 times relative to the new membrane. Only removing the membrane of the filtration unit and place it in tap water, the membrane resistance decrease $53.2 \%$. The physical cleaning provides a cleaning efficiency of $65.7 \%$. 


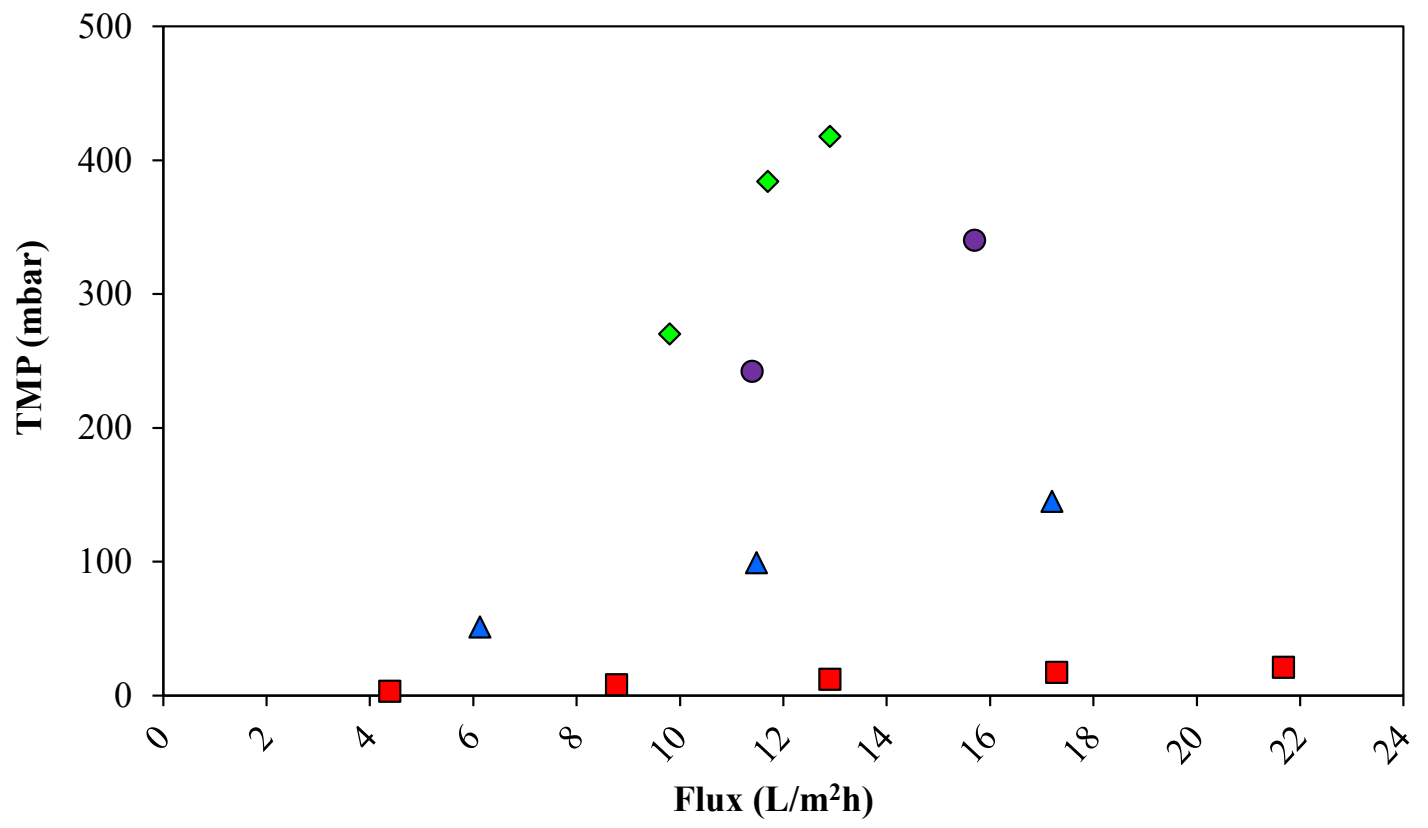

New membrane $\diamond$ Bulk solution $O$ Before physical cleaning $\Delta$ After physical cleaning

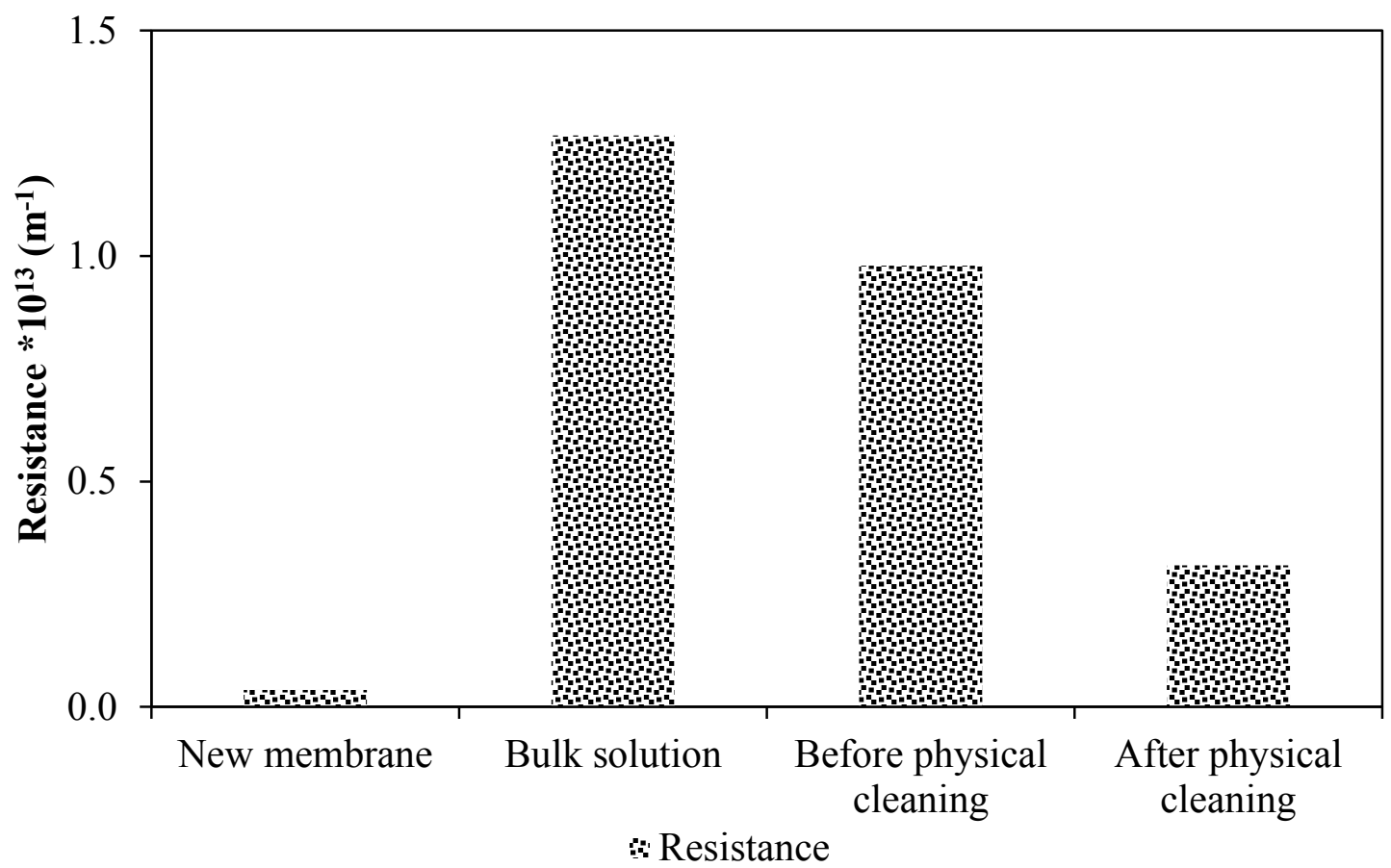

Figure 7.5. Filtration resistance of the membrane in water at $18 \pm 2^{\circ} \mathrm{C}$, in bulk solution of S.p.6 before and after the physical cleaning on day 462 . 

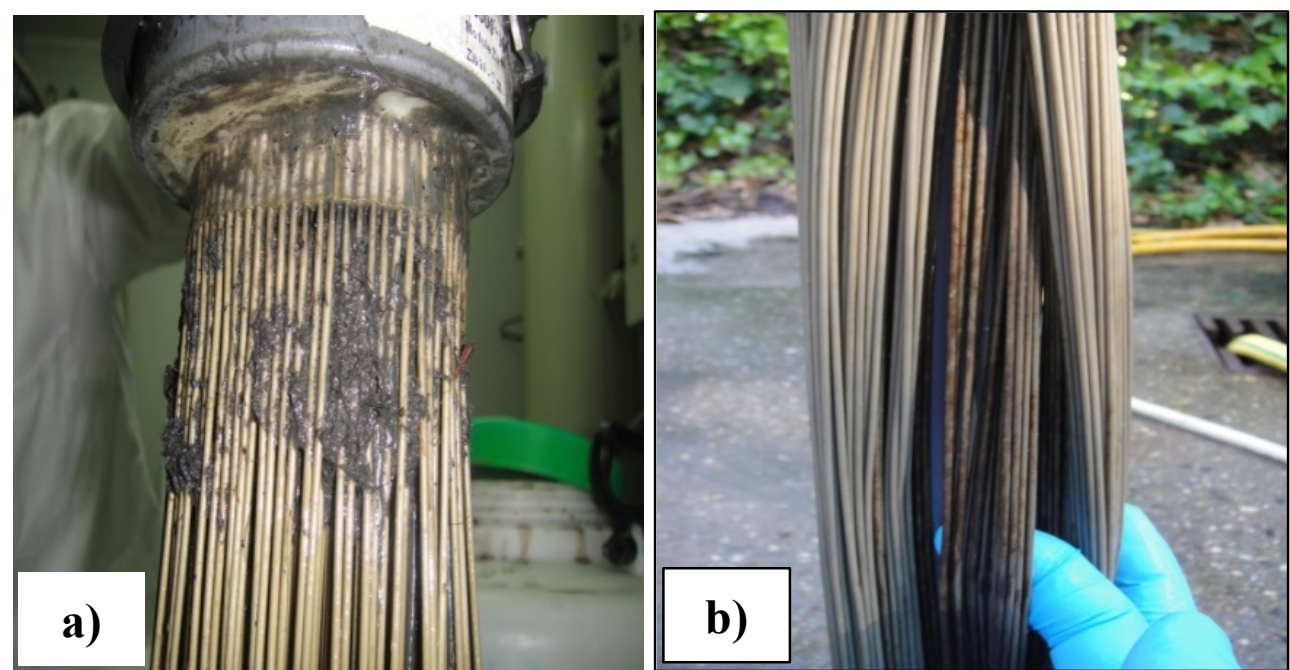

Figure 7.6. Evolution of physical appearance of the membrane module throughout the cleaning processes on day 462: a) Before physical cleaning b) After physical cleaning.

\section{- Physical and chemical cleaning ex-situ on day 552 of operation}

Figure 7.7 shows the behavior of the membrane along the cleaning procedure carried out on day 552 of operation. After the physical cleaning, a chemical cleaning with 1000 ppm of $\mathrm{NaClO}$ was done. The suspension caused an increase in resistance of $25.7 \%$. Nevertheles, the cleaning efficiency was $77.4 \%$. 


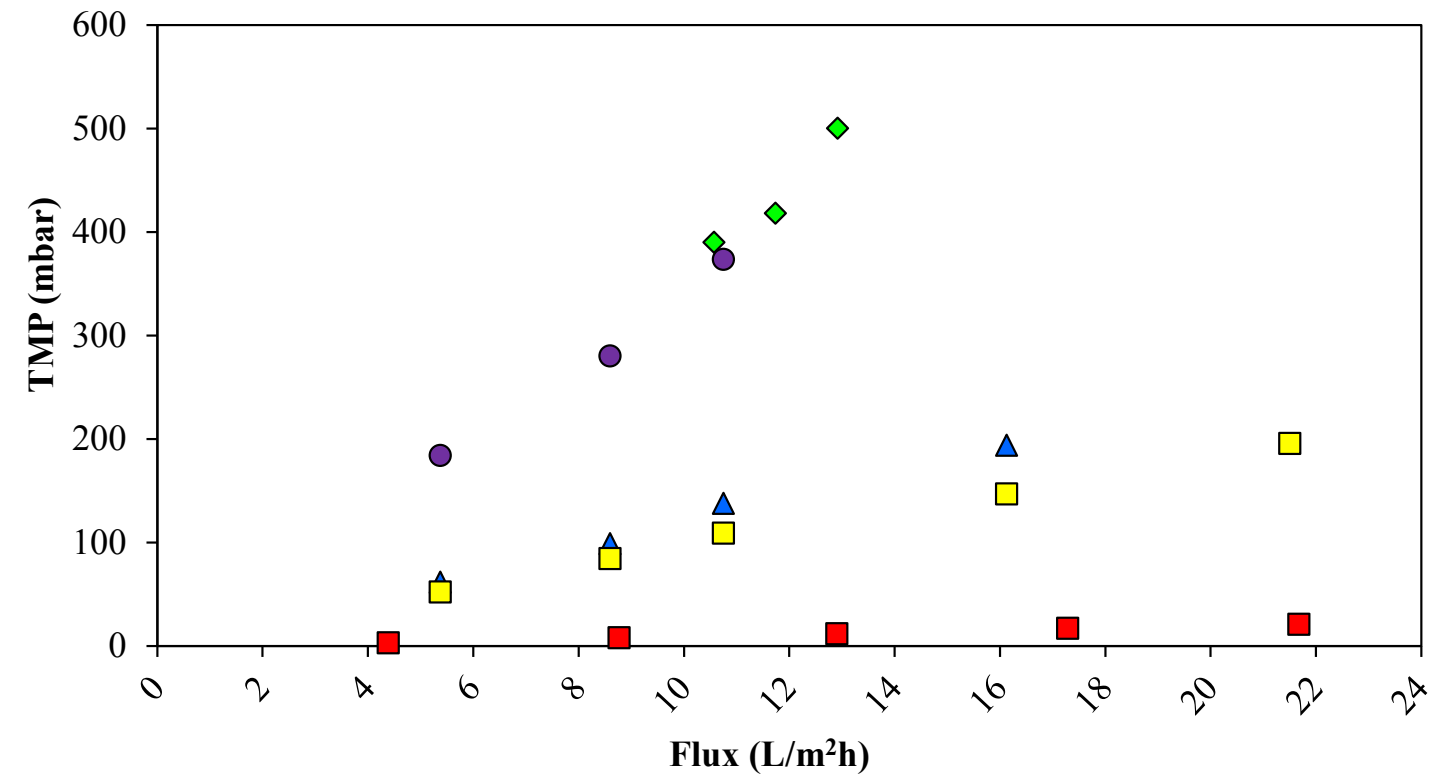

New membrane

$\Delta$ After physical cleaning

$\diamond$ Bulk solution

Before physical cleaning

$\square$ After oxidant cleaning

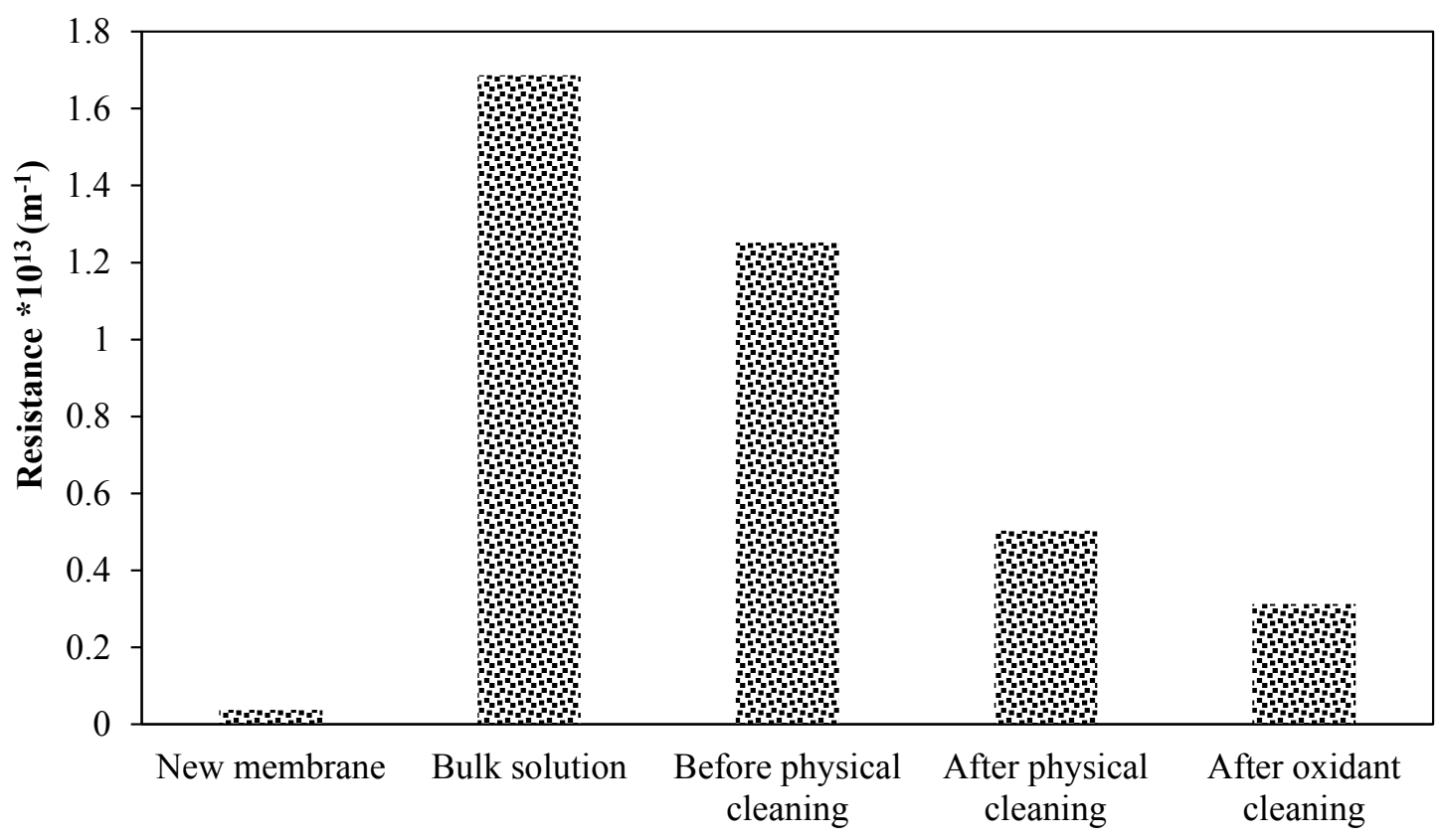

Resistance

Figure 7.7. Filtration resistance of the membrane in water at $18 \pm 2^{\circ} \mathrm{C}$, in bulk solution of S.p. 6 before and after the physical cleaning, and after oxidant cleaning on day 552. 

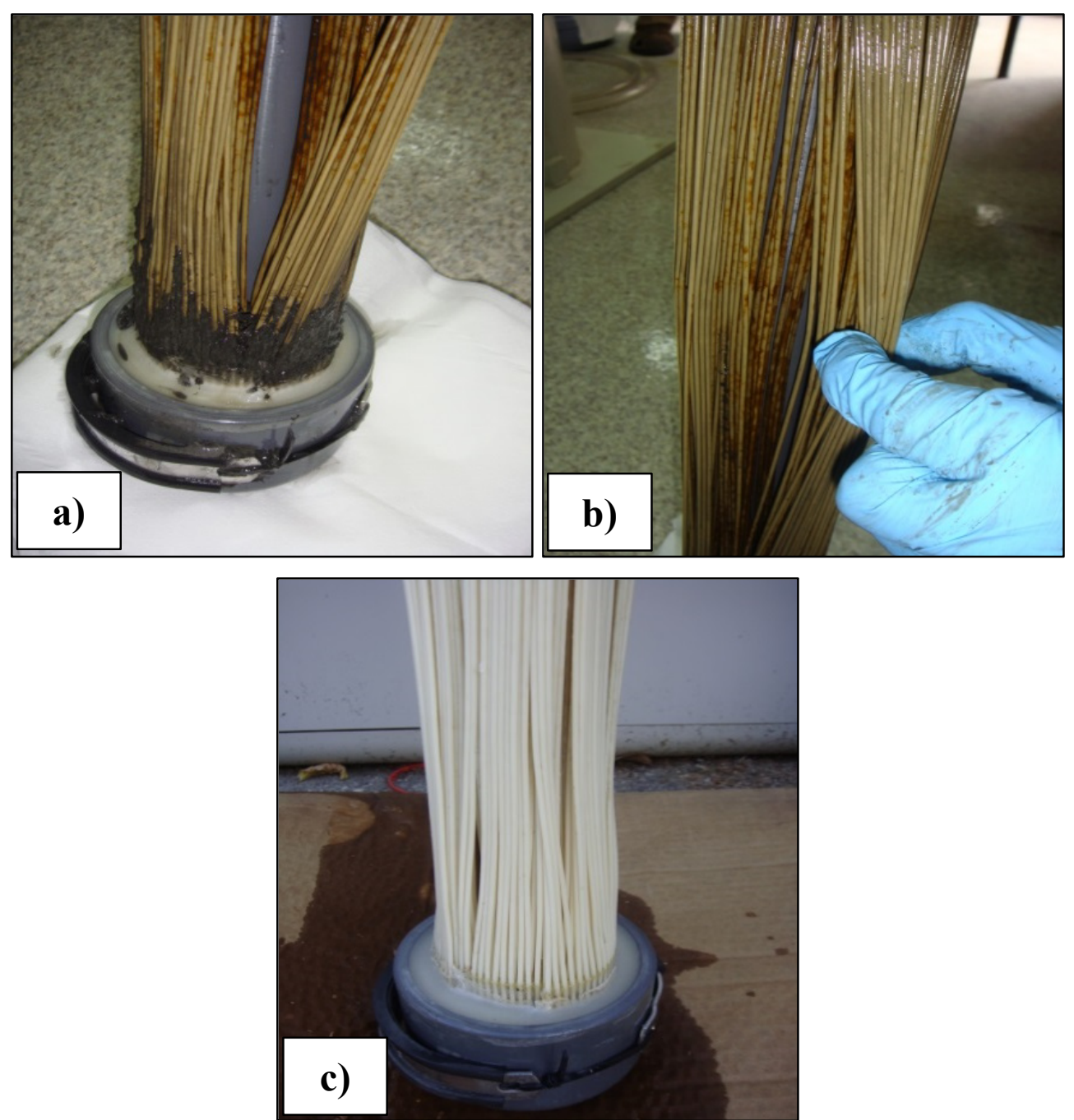

Figure 7.8. Evolution of physical appearance of the membrane module throughout the cleaning processes on day 552: a) Before physical cleaning b) After physical cleaning c) After oxidant cleaning.

- Physical and chemical cleaning ex-situ on day 623 of operation

Figure 7.9 shows the behavior of the membrane along the cleaning procedure carried out on day 623 of operation. After the physical cleaning, a chemical cleaning with 1000 ppm of $\mathrm{NaClO}$ was carried out, followed by an acid cleaning with $\mathrm{HCl}(1 \mathrm{~g} / \mathrm{L})$. The cleaning efficiency after the oxidant and acid cleaning was 54.7 and $59.4 \%$, respectively. This means that was an ineffective cleaning. 


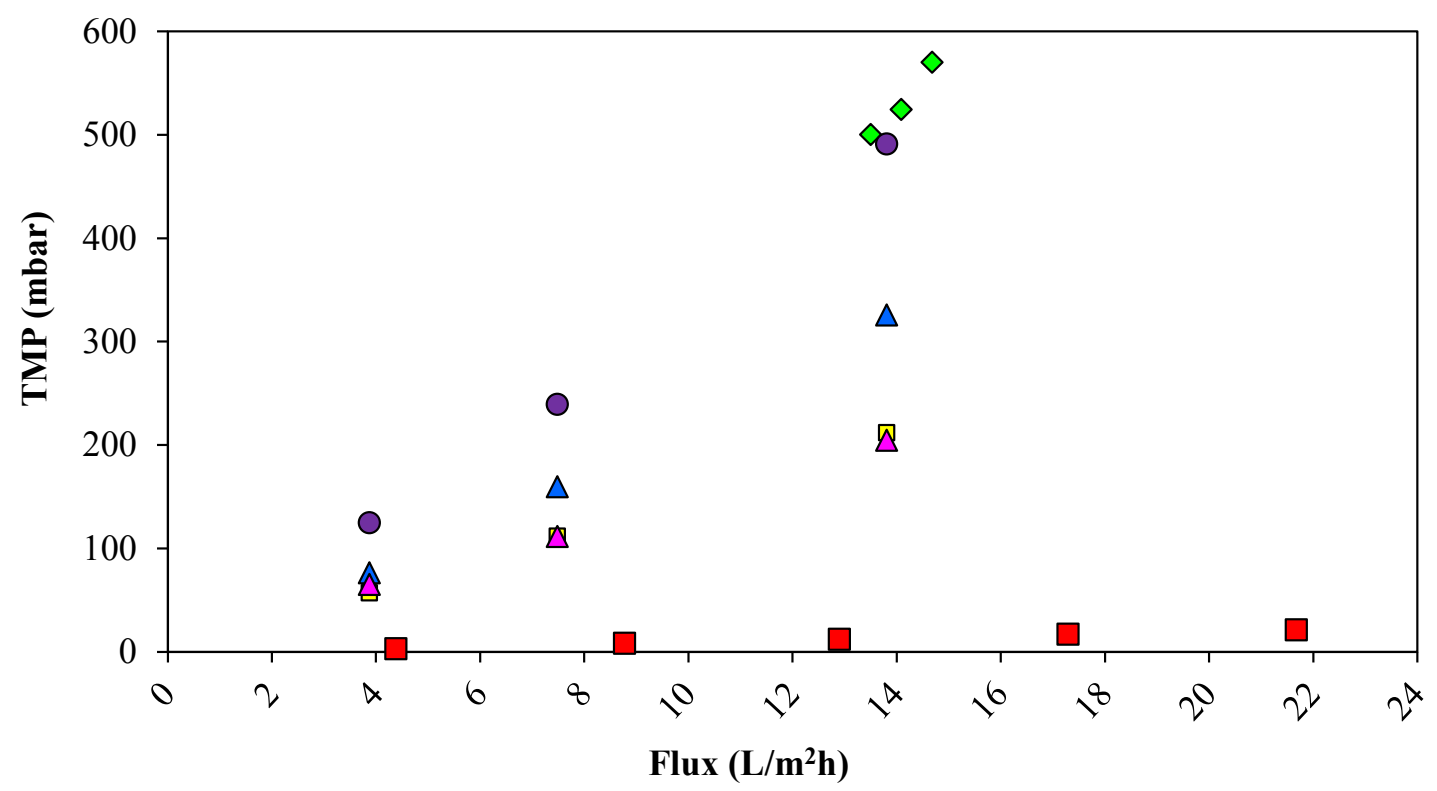

$\square$ New membrane

$\Delta$ After physical cleaning $\diamond$ Bulk solution

$\square$ After oxidant cleaning
OBefore physical cleaning

$\Delta$ After acid cleaning $(\mathrm{HCl})$

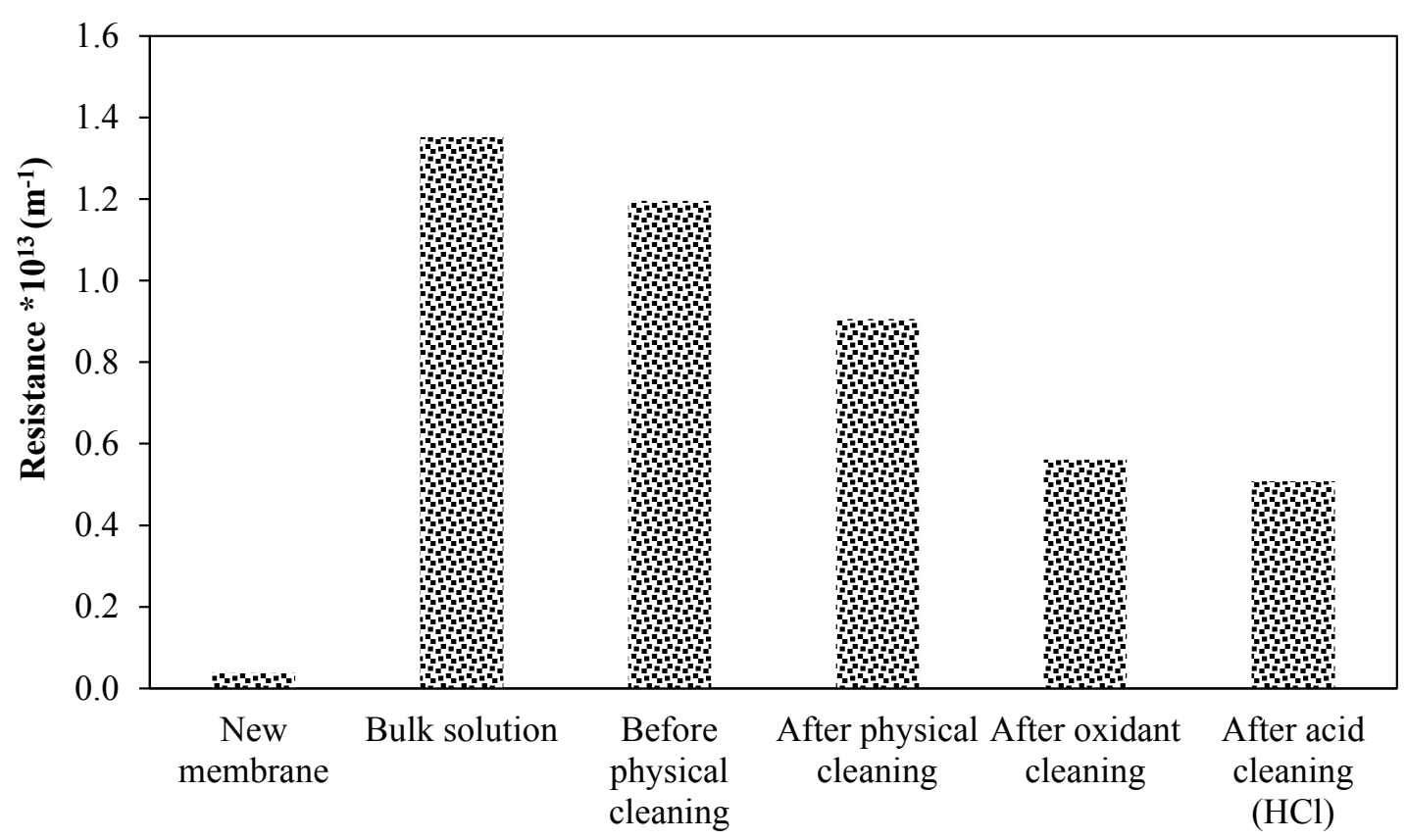

Resistance

Figure 7.9. Filtration resistance of the membrane in water at $18 \pm 2^{\circ} \mathrm{C}$ in bulk solution of S.p.6, before and after the physical cleaning, after oxidant and acid cleaning on day 623 . 

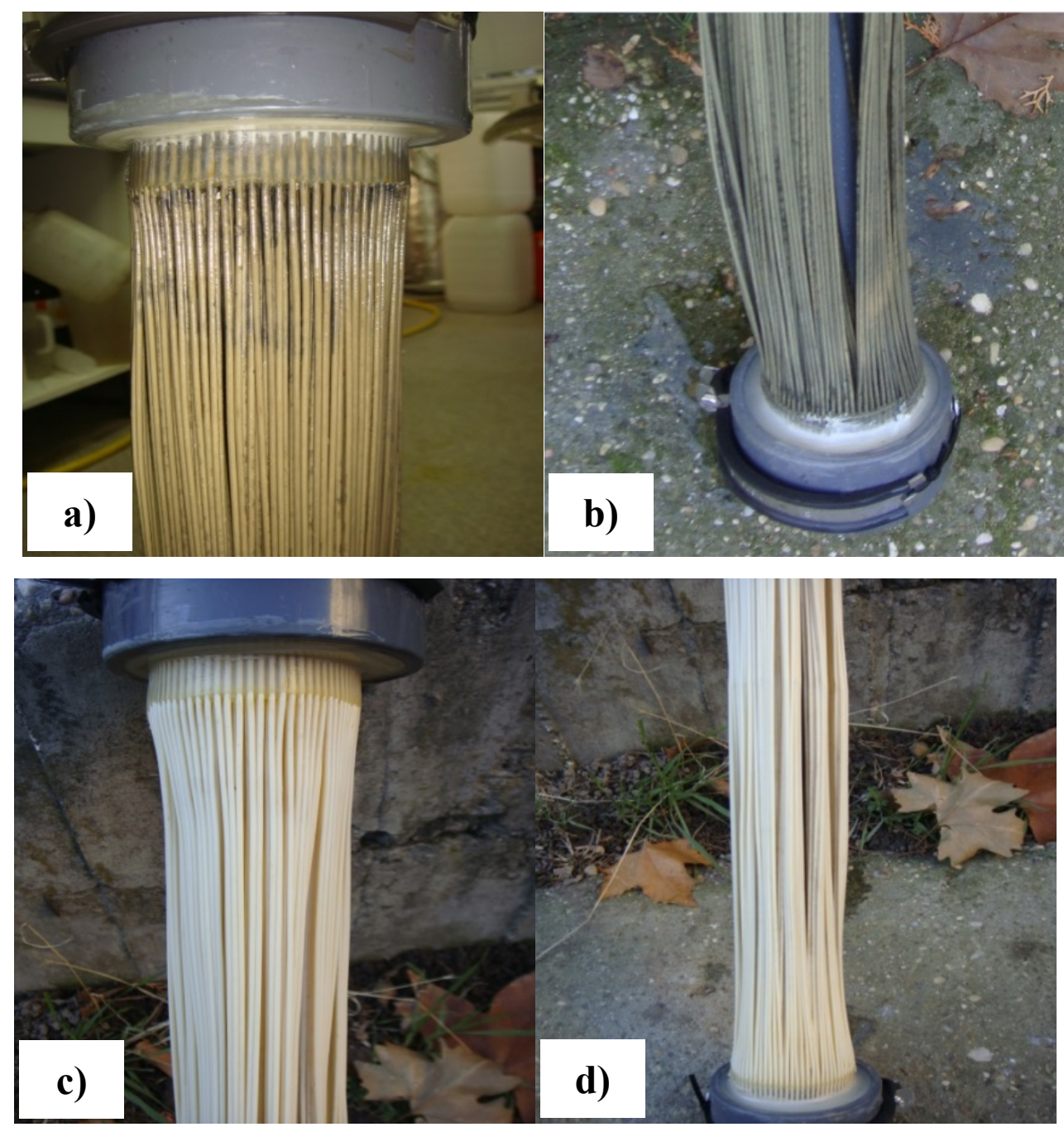

Figure 7.10. Physical appearance of the membrane module throughout the cleaning processes on day 623: a) Before physical cleaning c) After physical cleaning d) After oxidant cleaning e) After acid cleaning.

\section{- Physical and chemical cleaning ex-situ on day 746 of operation}

Figure 7.11 shows the behavior of the membrane along the cleaning procedure carried out on day 746 of operation. After the physical cleaning an oxidant cleaning with 1000 ppm of $\mathrm{NaClO}$ was carried out, followed by a cleaning with $1 \mathrm{~g} / \mathrm{L}$ of $\mathrm{HCl}$. After two years of operation, the figure 7.11 shown that after the oxidant cleaning was reached a cleaning efficiency of $34.1 \%$. The acid cleaning provides a decrease on the membrane resistance on $17.8 \%$, giving a total cleaning efficiency of $45.9 \%$. 

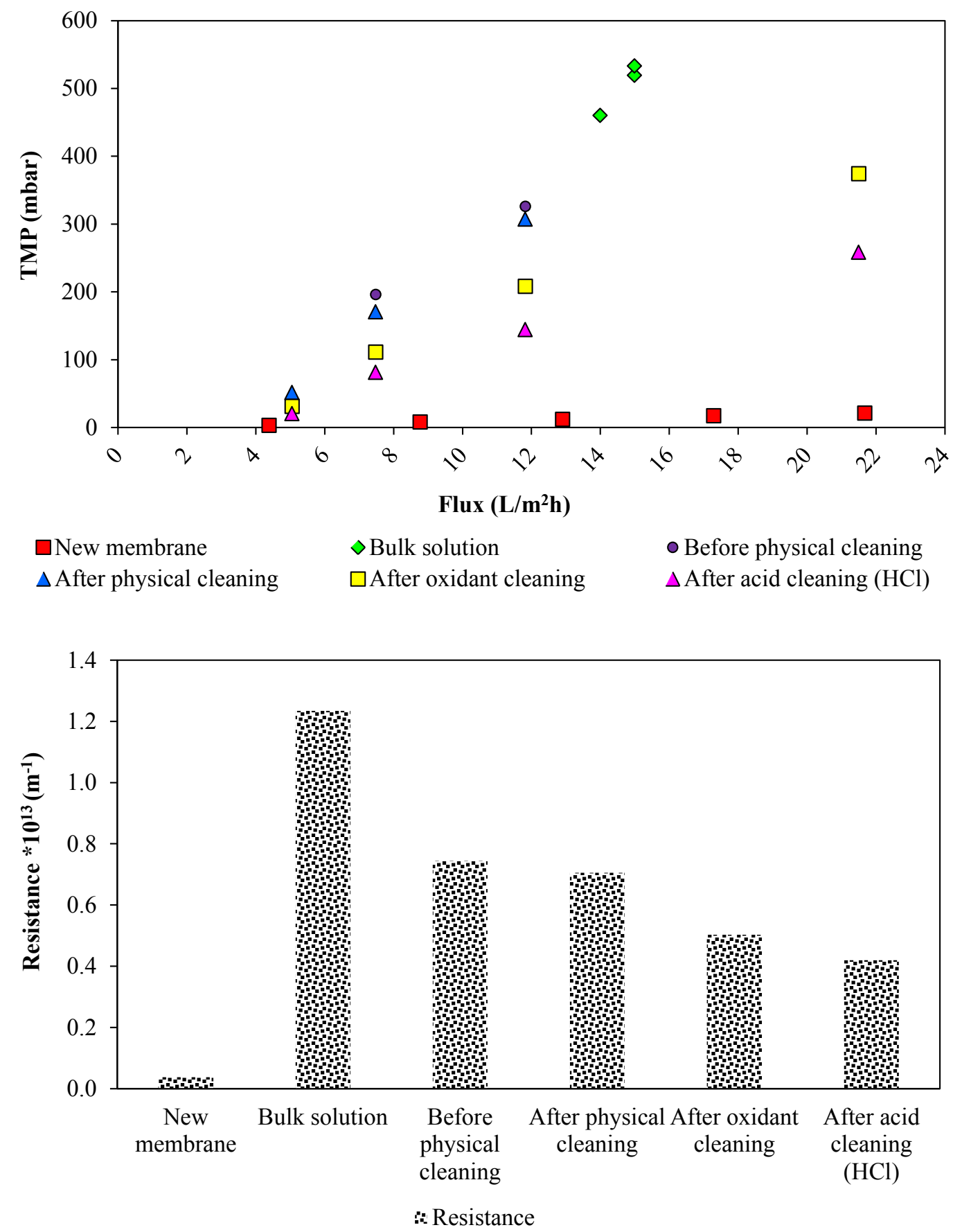

Figure 7.11. Resistance of the membrane in water at $18 \pm 2^{\circ} \mathrm{C}$, in bulk solution of S.p.6, before and after the physical cleaning, after oxidant and acid cleaning on day 746 . 

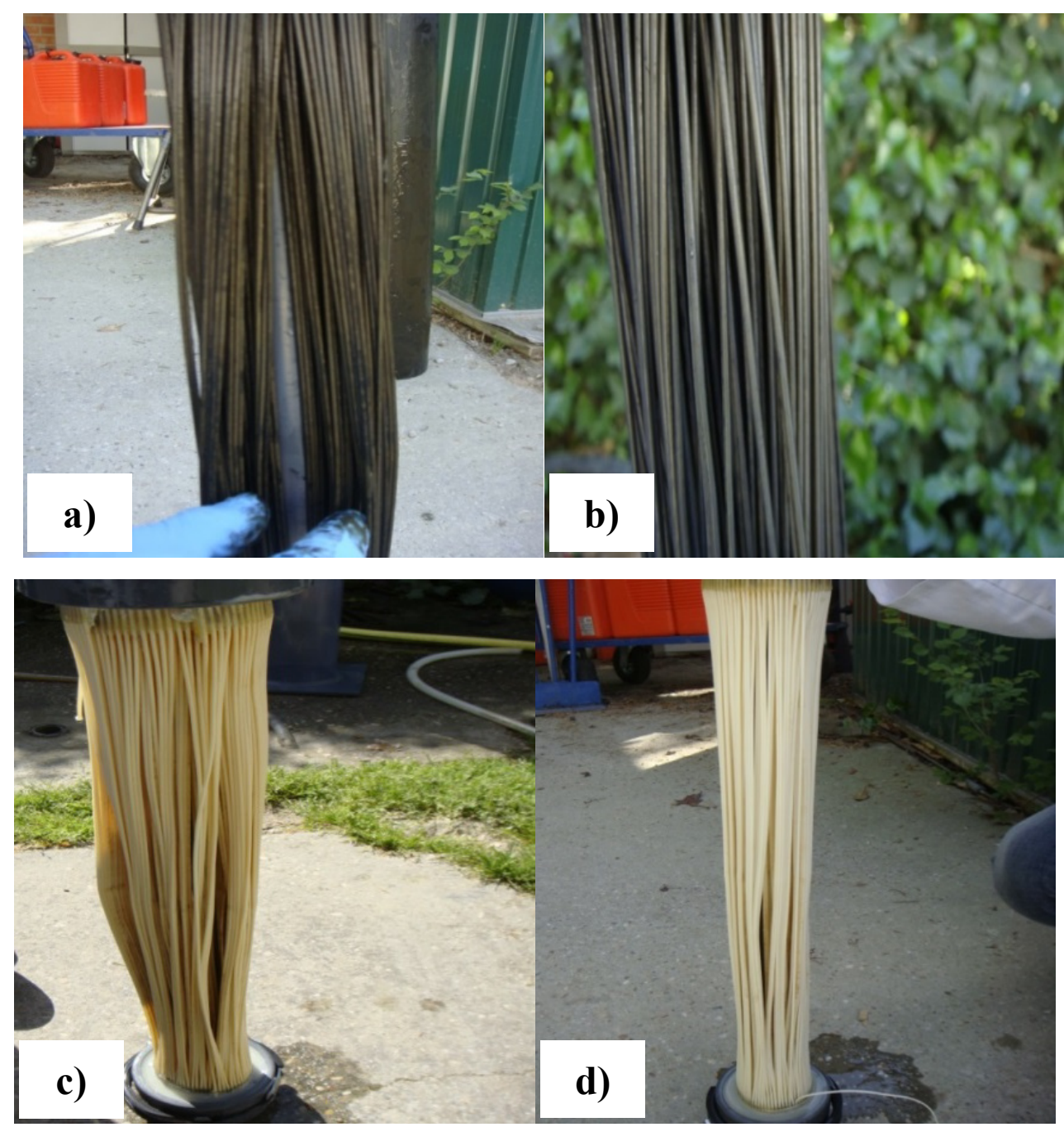

Figure 7.12. Evolution of physical appearance of the membrane module throughout the cleaning processes on day 746: a) Before physical cleaning b) After physical cleaning c) After oxidant cleaning d) After acid cleaning.

\section{- Physical and chemical cleaning ex-situ on day 799 of operation}

Figure 7.13 shows the behavior of the membrane along the cleaning procedure carried out on day 799 of operation. After the physical cleaning an oxidant cleaning with 1000 ppm of $\mathrm{NaClO}$ was carried out, followed by a cleaning with $1 \mathrm{~g} / \mathrm{L}$ of $\mathrm{HCl}$. The membrane resistance in the bulk solution and after physical cleaning was $1.209 * 10^{13} \mathrm{~m}^{-1}$ and $0.51 * 10^{13} \mathrm{~m}^{-1}$, respectively. Proceeding to an oxidant and acid cleaning, the membrane resistance was $0.348 * 10^{13}$ and $0.241 * 10^{13} \mathrm{~m}^{-1}$, respectively, reaching a cleaning efficiency of $56.9 \%$. 


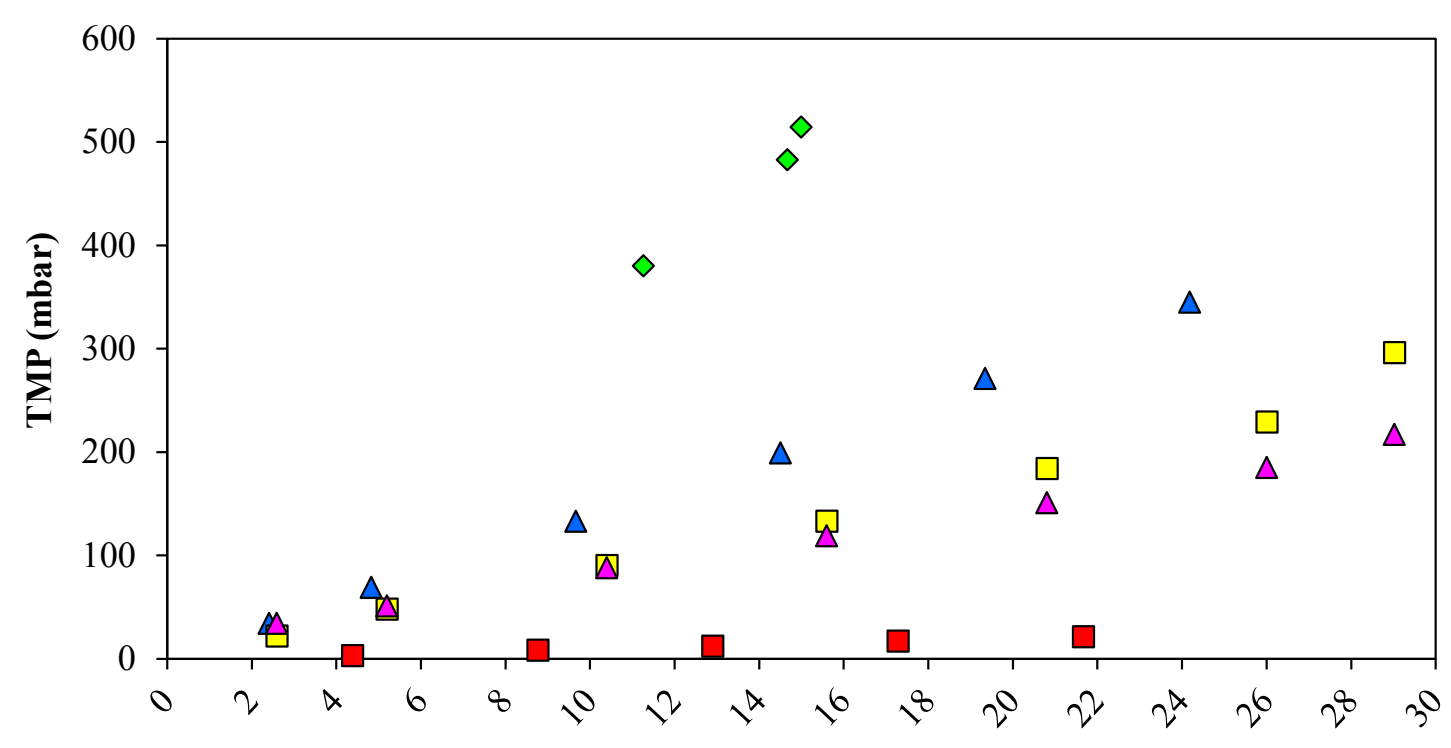

Flux $\left(\mathbf{L} / \mathbf{m}^{2} h\right)$

$\square$ New membrane

$\square$ After oxidant cleaning $\diamond$ Bulk solution

$\Delta$ After acid cleaning $(\mathrm{HCl})$

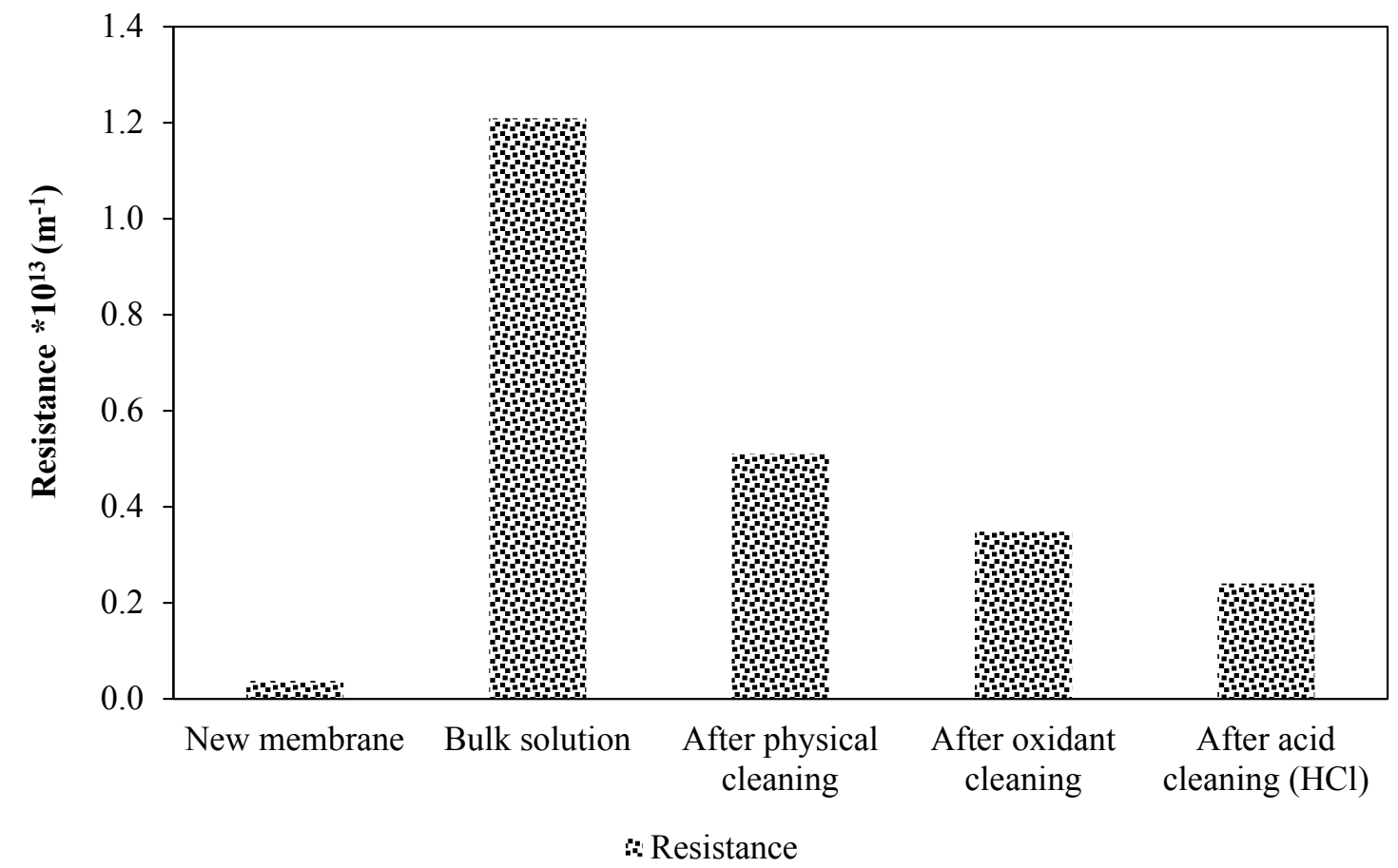

Figure 7.13. Resistance of the membrane in water at $18 \pm 2^{\circ} \mathrm{C}$, in bulk solution of S.p.6, before and after the physical cleaning, after oxidant and acid cleaning on day 799.

\section{- Physical and chemical cleaning ex-situ on day 1044 of operation}

Figure 7.14 shows the behavior of the membrane along the cleaning procedure carried out on day 1044 of operation. After the physical cleaning an oxidant cleaning with 1000 
ppm of $\mathrm{NaClO}$ was carried out. As illustrated in Fig. 7.14, the membrane resistance due to the suspension inside the filtration unit decreases a $13.6 \%$, from 1.177 to $1.017^{*} 10^{13}$ $\mathrm{m}^{-1}$, respectively. Due to the physical cleaning the membrane resistance decreases $75 \%$, meanwhile, with the oxidant cleaning, the membrane resistance of $0.151^{*} 10^{13} \mathrm{~m}^{-1}$ and a cleaning efficiency of $88.5 \%$ were reached, respecyively.

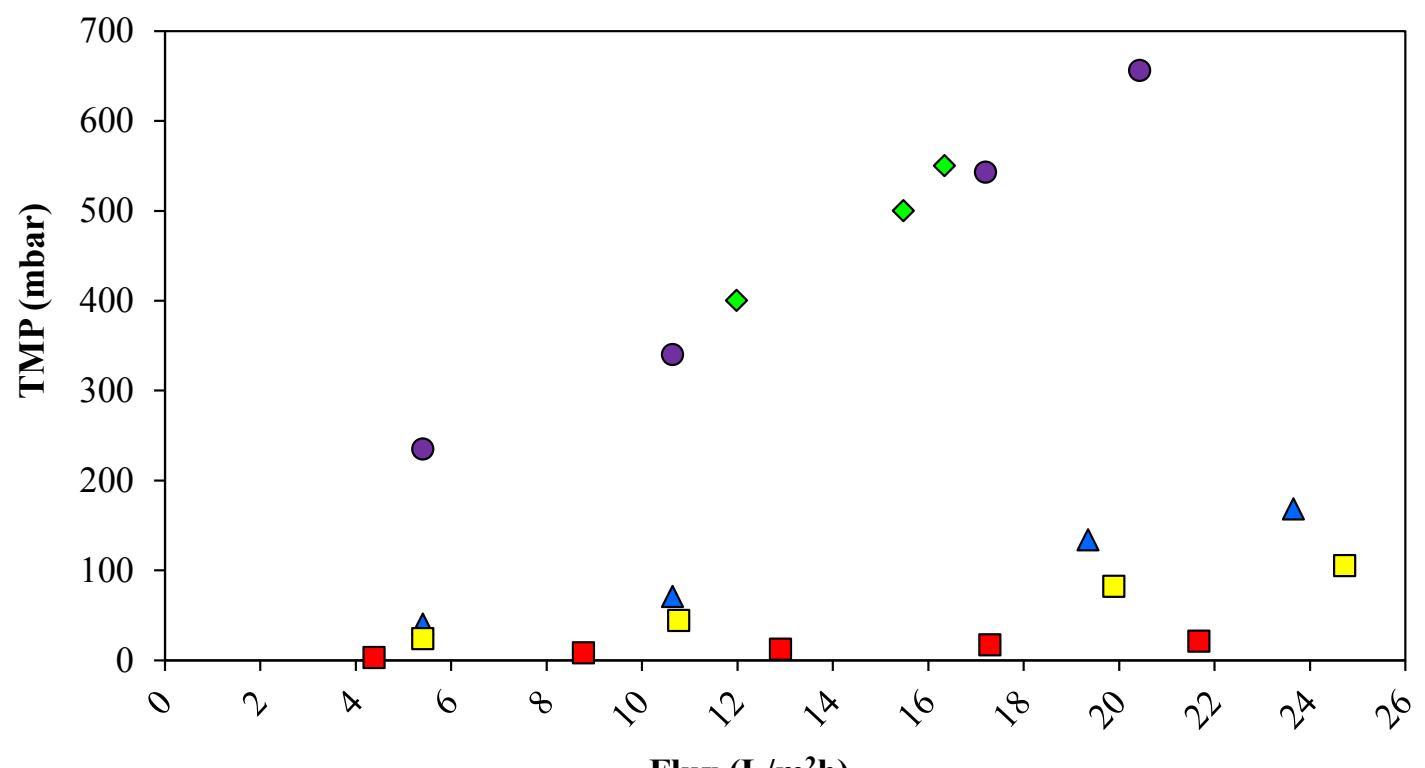

$\square$ New membrane

$\Delta$ After physical cleaning $\diamond$ Bulk solution

$\square$ After oxidant cleaning

OBefore physical cleaning

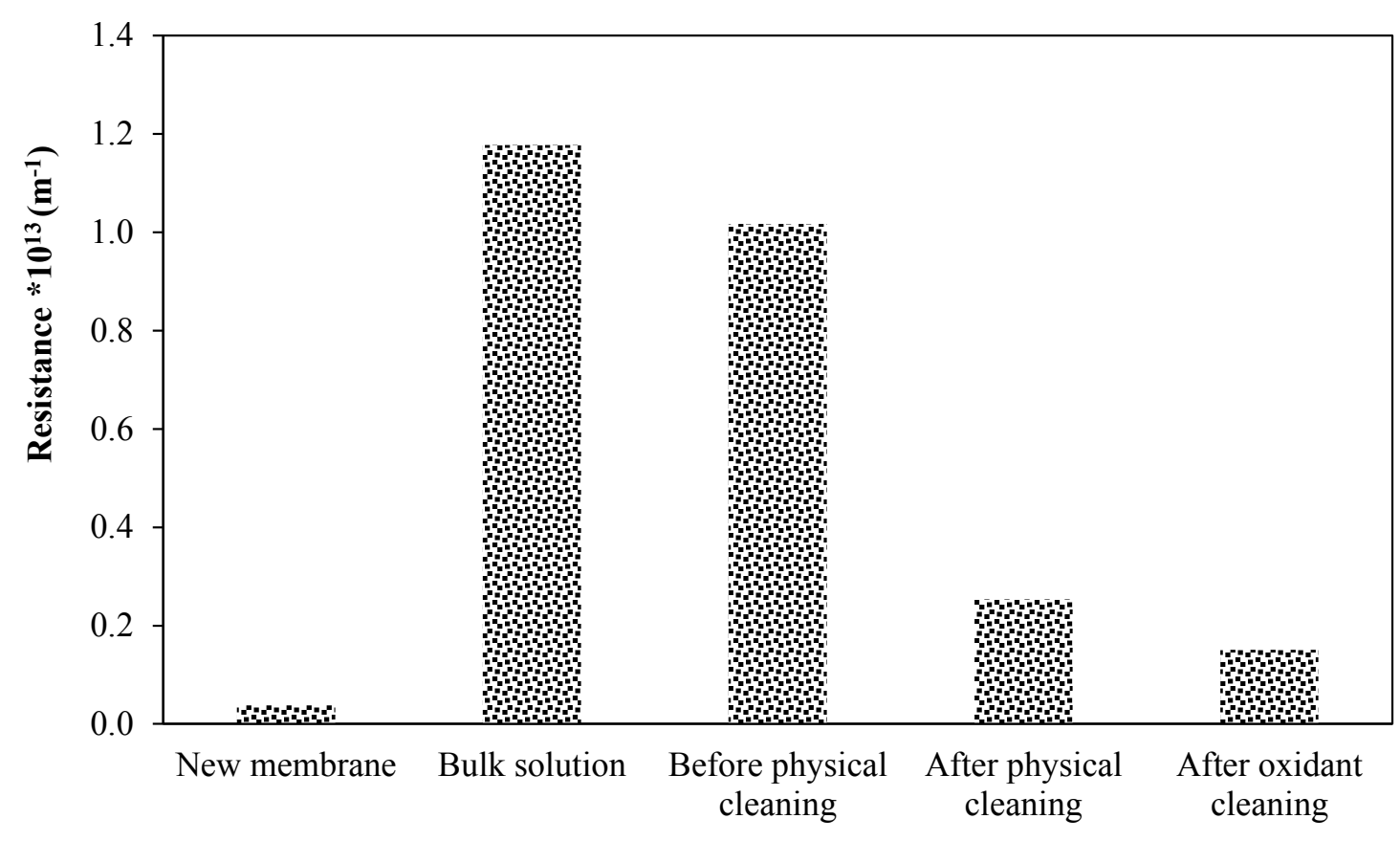

Resistance

Figure 7.14. Resistance of the membrane in water at $18 \pm 2^{\circ} \mathrm{C}$, in bulk solution of S.p.6, before and after the physical cleaning, and after oxidant cleaning on day 1044 . 


\section{- Physical and chemical cleaning ex-situ on day 1163 of operation}

Figure 7.15 shows the behavior of the membrane along the cleaning procedure carried out on day 1163 of operation. After the physical cleaning an oxidant cleaning with 1000 ppm of $\mathrm{NaClO}$ was carried out, followed by a cleaning with $1 \mathrm{~g} / \mathrm{L}$ of $\mathrm{HCl}$. As illustrated in Fig. 7.15, the membrane resistance due to the suspension and to the physical cleaning was $11.5 \%, 69.4 \%$, respectively, reaching a cleaning efficiency of $87.1 \%$.

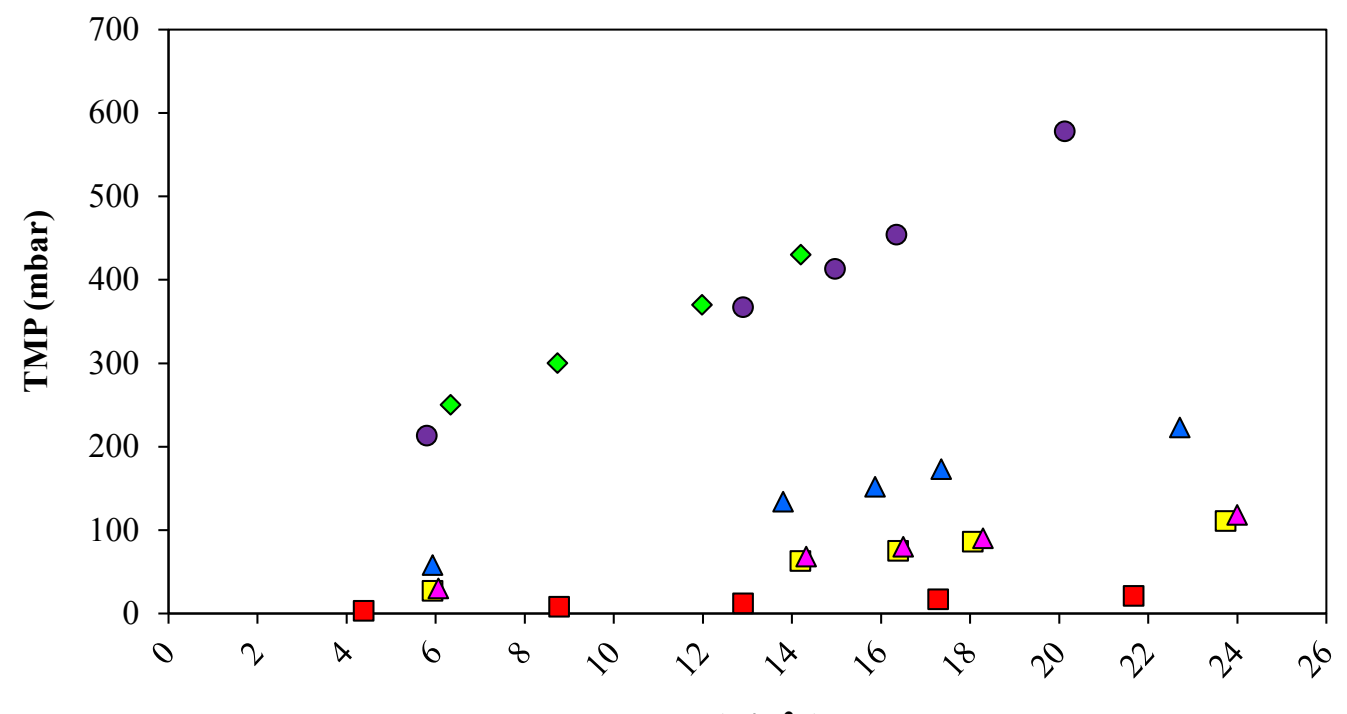

Flux $\left(\mathbf{L} / \mathbf{m}^{2} \mathbf{h}\right)$
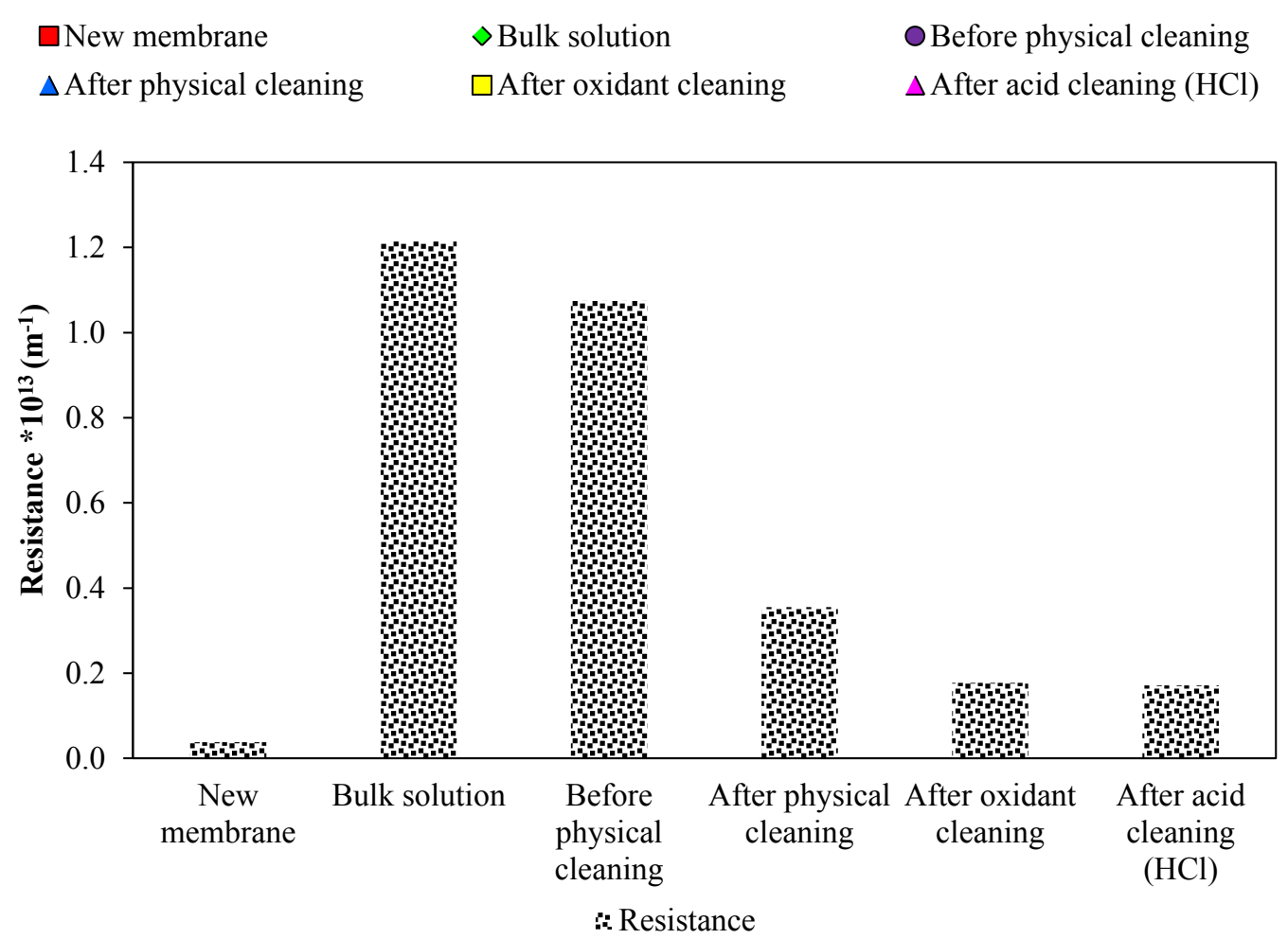

Figure 7.15. Resistance of the membrane in water at $18 \pm 2^{\circ} \mathrm{C}$, in bulk solution of S.p.6, before and after the physical cleaning, after oxidant and acid cleaning on day 1163. 
- Physical and chemical cleaning ex-situ on day 1338 of operation

Figure 7.16 shows the behavior of the membrane along the cleaning procedure carried out on day 1338 of operation. After the physical cleaning an oxidant cleaning with 1000 ppm of $\mathrm{NaClO}$ was carried out. A higher VS concentration inside the membrane tank was observed. The membrane resistance due to the physical cleaning decrease $19.4 \%$, reaching a cleaning efficiency $77 \%$, due to the oxidant cleaning. 


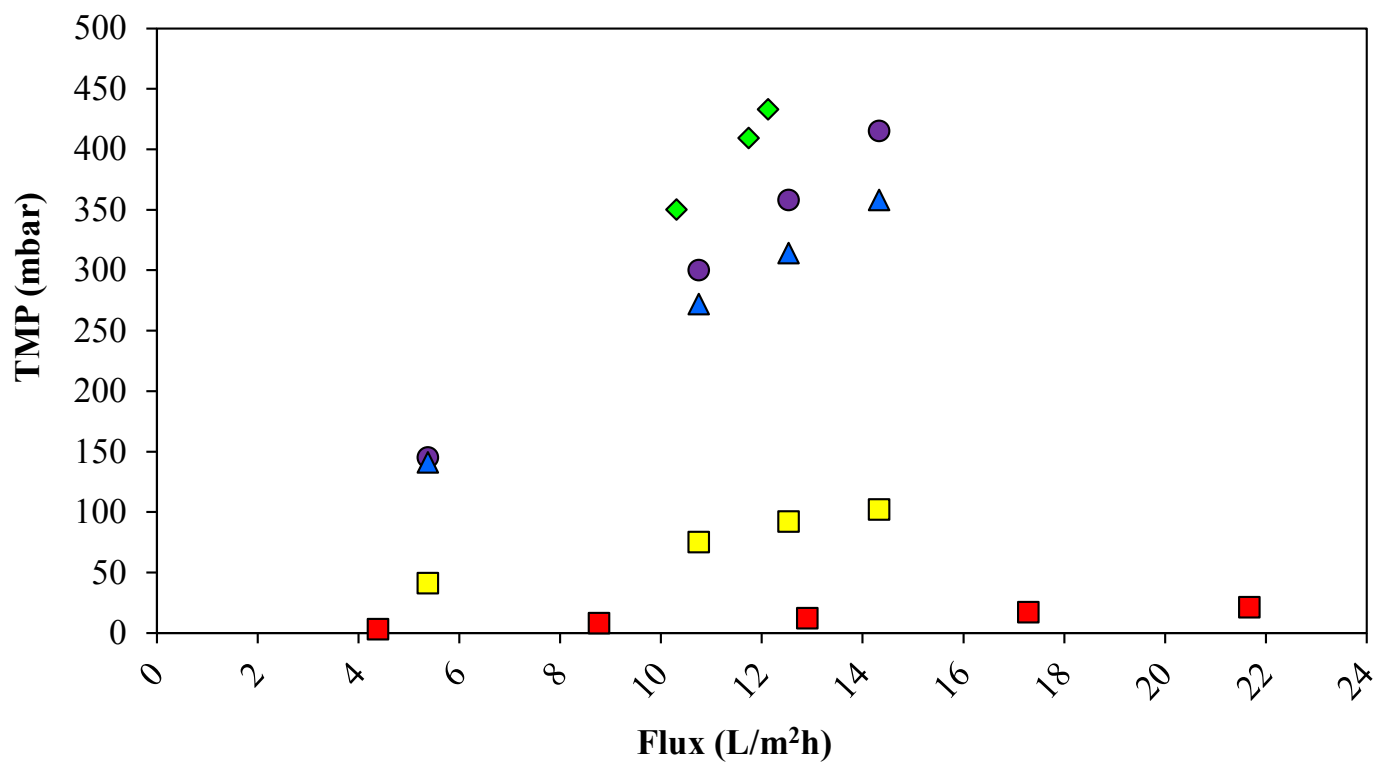

$\square$ New membrane

$\diamond$ Bulk solution

O Before physical cleaning

$\Delta$ After physical cleaning

$\square$ After oxidant cleaning

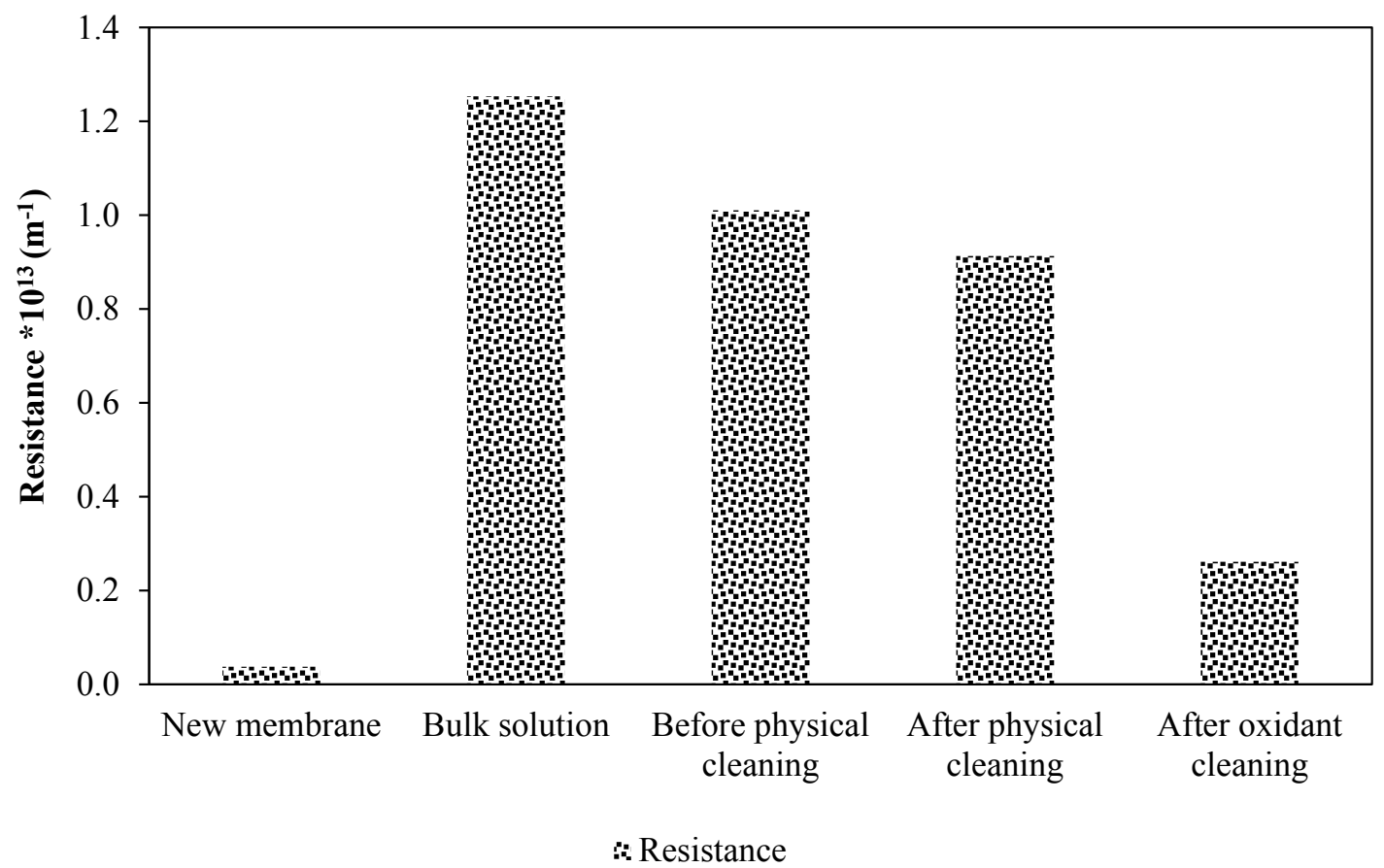

Figure 7.16. Resistance of the membrane in water at $18 \pm 2^{\circ} \mathrm{C}$, in bulk solution of S.p.6, before and after the physical cleaning, and after oxidant cleaning on day 1338. 

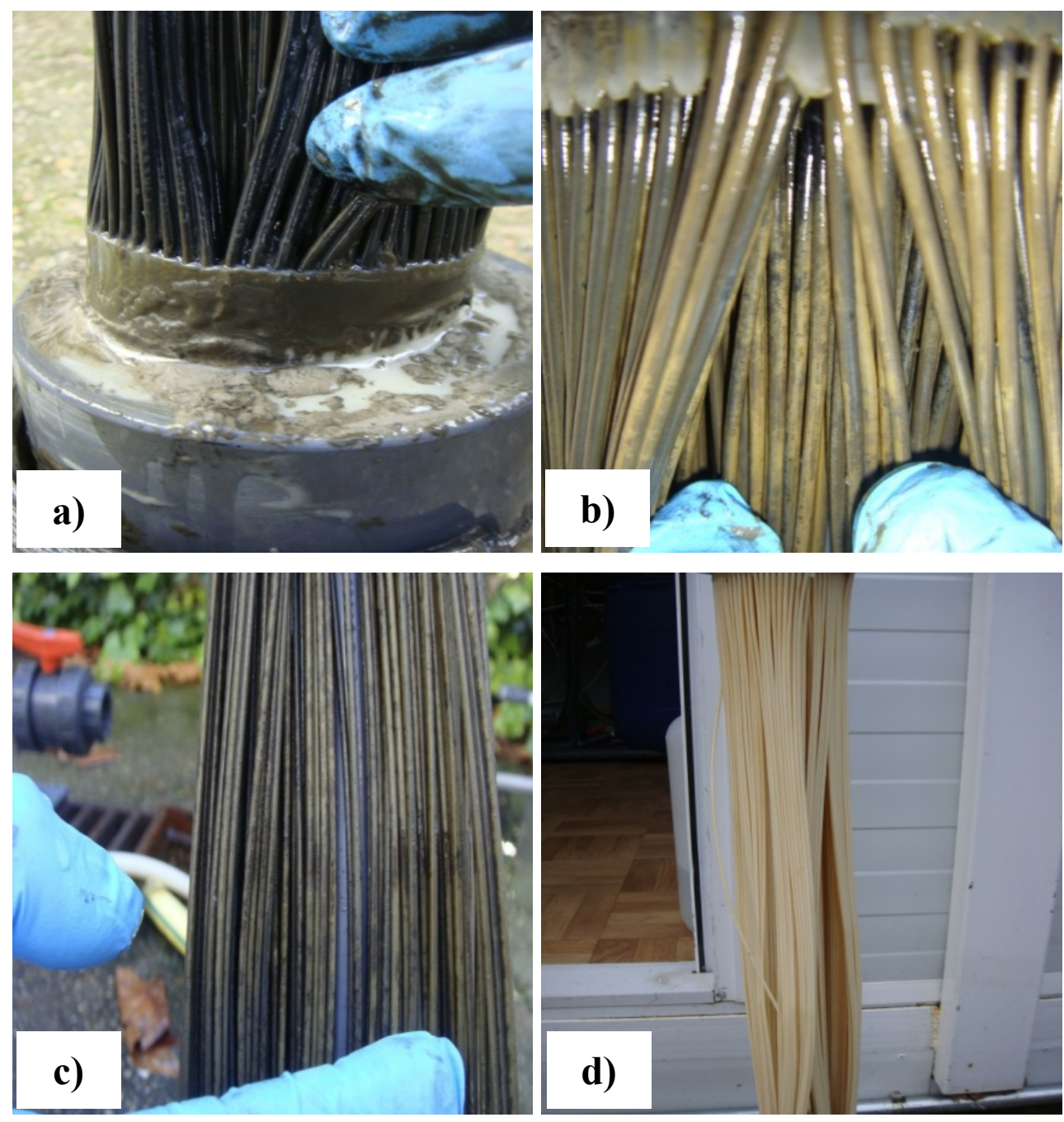

Figure 7.17. Evolution of physical appearance of the membrane module throughout the cleaning processes on day 1338: a) Bulk solution b) Before physical cleaning c) After physical cleaning d) After oxidant cleaning.

\section{- Physical and chemical cleaning ex-situ on day 1429 of operation}

Figure 7.18 shows the behavior of the membrane along the cleaning procedure carried out on day 1429 of operation. After the physical cleaning an oxidant cleaning with 1000 ppm of $\mathrm{NaClO}$ was carried out. After the physical cleaning the membrane resistance decreases a $17.4 \%$, whilst due to the oxidant cleaning the membrane resistance is reduced in $55.1 \%$, reaching a cleaning efficiency of $63.2 \%$. 


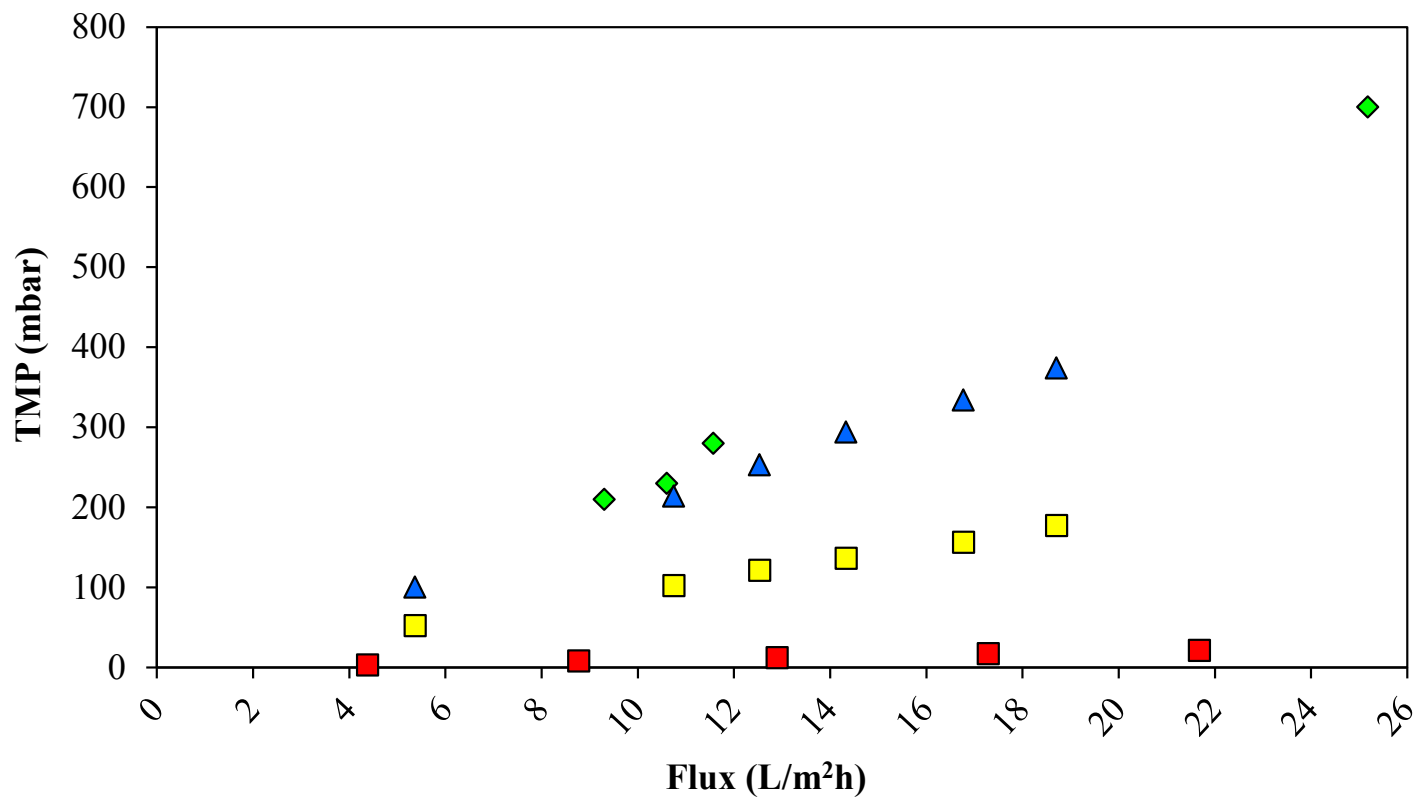

$\square$ New membrane $\diamond$ Bulk solution $\Delta$ After physical cleaning $\square$ After oxidant cleaning

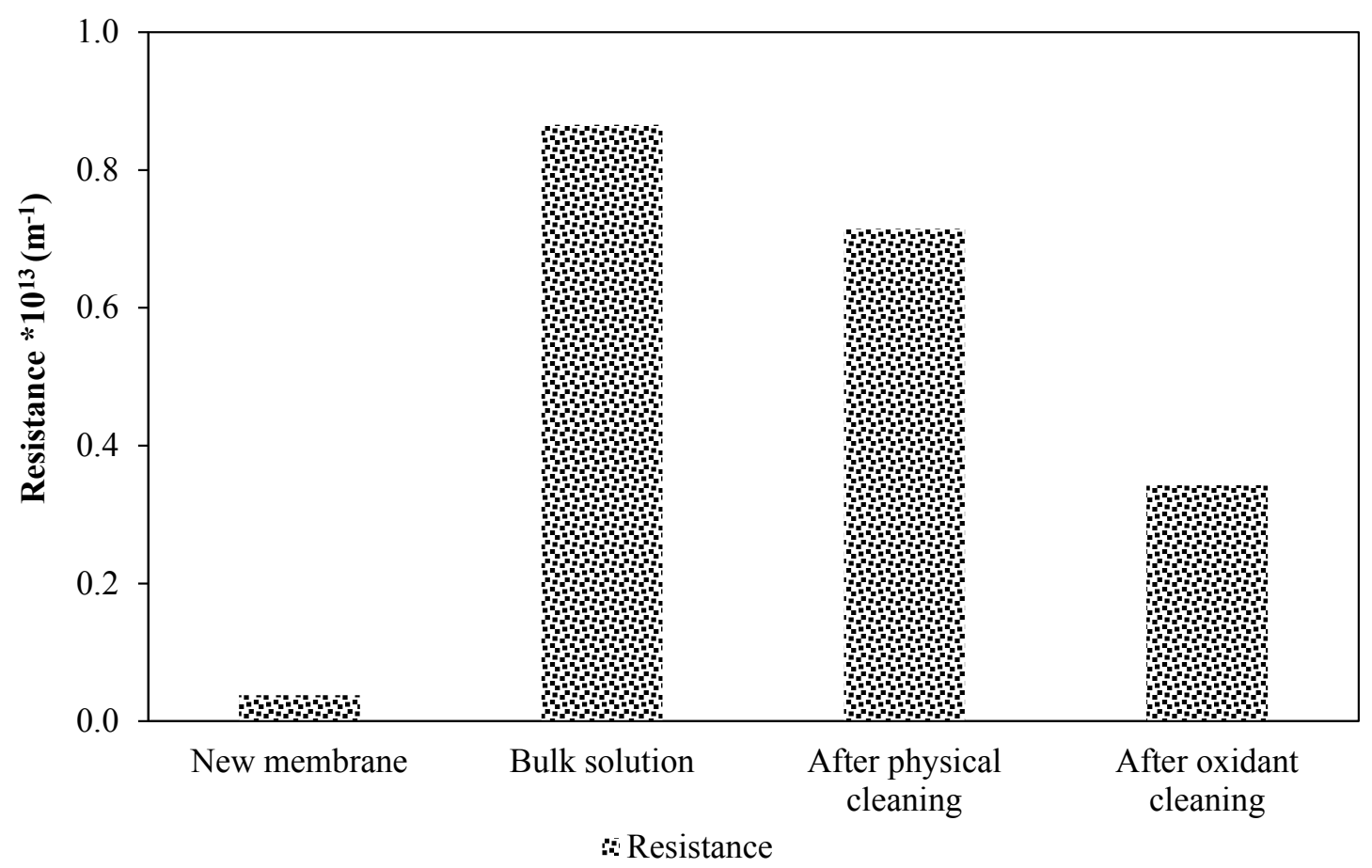

Figure 7.18. Resistance of the membrane in water at $18 \pm 2^{\circ} \mathrm{C}$, in bulk solution of S.p.6, after the physical cleaning, and after oxidant cleaning on day 1429. 
The characterization of the membrane after each cleaning procedure along the operation of the AnMBR was represented in the fig. 7.19.

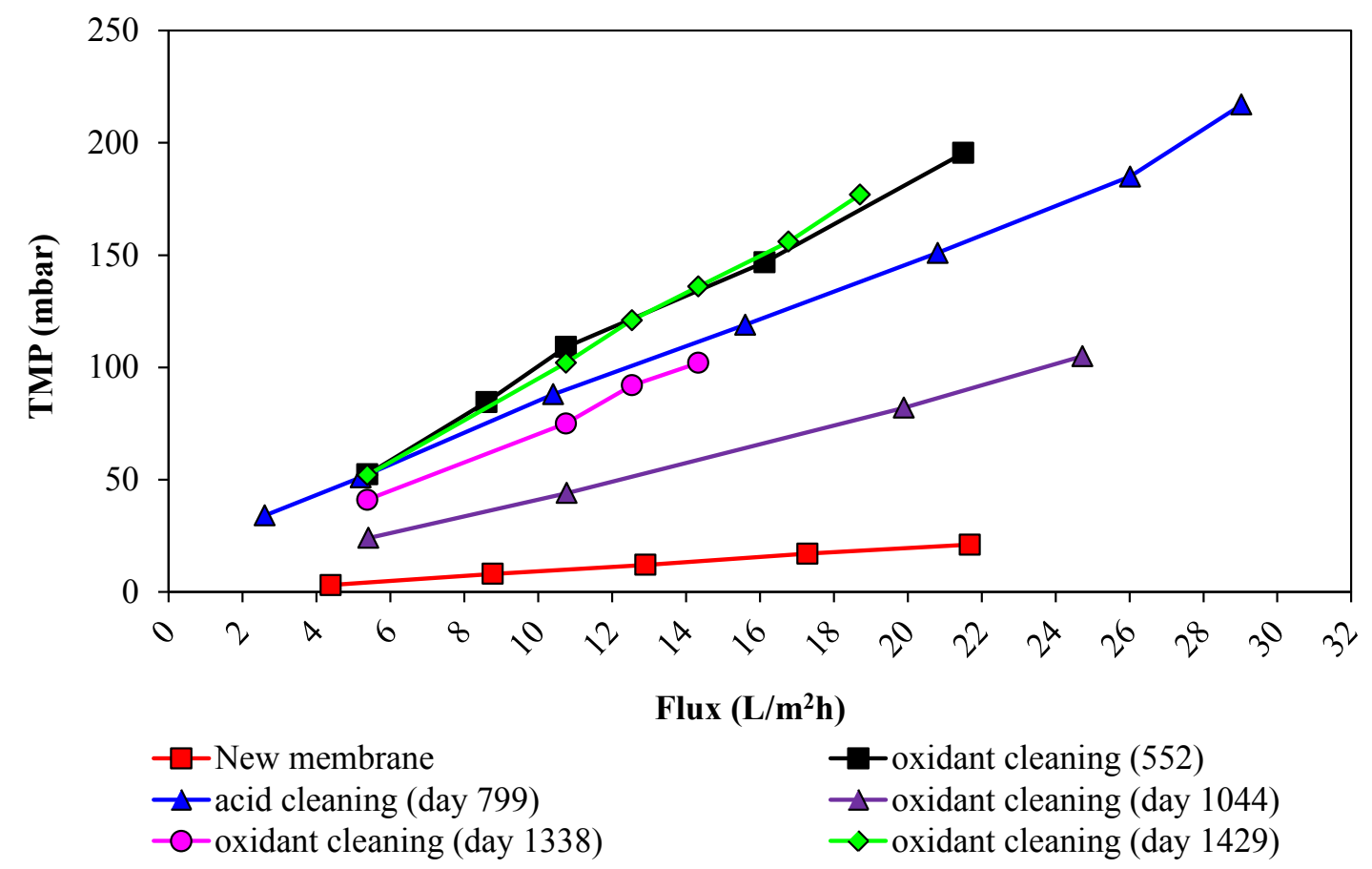

Figure 7.19. Evolution of the TMP after each cleaning procedure.

Table 7.1 summarizes the operating conditions of the membrane tank during the operation of the AnMBR, when cleaning was carried out.

Table 7.1. Operation conditions (mean values) in the membrane module (S.p.6) between each period of cleaning.

\begin{tabular}{cccc}
\hline Time $(\mathbf{d})$ & $\mathbf{V S}(\mathbf{g} / \mathbf{L})$ & $\mathbf{J}\left(\mathbf{L} / \mathbf{m}^{2} \mathbf{h}\right)$ & $\mathbf{u}_{\mathbf{g}}(\mathbf{m} / \mathbf{h})$ \\
\hline 337 & $0.7 \pm 0.2$ & $5.2 \pm 2.5$ & 27.3 \\
462 & $4.2 \pm 1.0$ & $11.5 \pm 1.3$ & 60 \\
552 & $4.3 \pm 0.9$ & $11.7 \pm 0.9$ & 60 \\
623 & $1.1 \pm 0.5$ & $13.0 \pm 1.5$ & 60 \\
746 & $1.1 \pm 0.5$ & $14.7 \pm 0.5$ & 60 \\
799 & $2.4 \pm 0.4$ & $11.3 \pm 1.7$ & 60 \\
1044 & $6.9 \pm 2.1$ & $15.3 \pm 1.8$ & 60 \\
1164 & $2.2 \pm 0.4$ & $13.1 \pm 1.1$ & 60 \\
1338 & $5.0 \pm 1.7$ & $11.4 \pm 0.8$ & 60 \\
1429 & $2.4 \pm 0.4$ & $10.5 \pm 0.9$ & 60 \\
\hline
\end{tabular}


In the table 7.2 summarizes the cleaning efficiency after the physical/chemical cleaning. The original membrane resistance and permeability is never recovered once a membrane is fouled through normal operation, a residual resistance remains which can be defined as 'irrecoverable fouling'. 
Table 7.2. Effect of the cleaning procedures on membrane resistance, during the entire period of operation.

\begin{tabular}{|c|c|c|c|c|c|c|c|c|}
\hline $\begin{array}{l}\text { Time } \\
\text { (d) }\end{array}$ & $\begin{array}{l}\text { Type of } \\
\text { cleaning }\end{array}$ & $\begin{array}{l}R^{*} 10^{13} \\
\left(m^{-1}\right)^{(1)}\end{array}$ & $\begin{array}{l}R^{*} 10^{13} \\
\left(m^{-1}\right)^{(2)}\end{array}$ & $\begin{array}{l}R^{*} 10^{13} \\
\left(m^{-1}\right)^{(3)}\end{array}$ & $\begin{array}{l}R^{*} 10^{13} \\
\left(m^{-1}\right)^{(4)}\end{array}$ & $\begin{array}{c}R_{\text {after }} * 10^{13} \\
\left(m^{-1}\right)^{(5)}\end{array}$ & $\begin{array}{c}\text { Permeability } \\
\left(\mathrm{L} \mathrm{m}^{-2} \mathrm{~h}^{-1} \mathrm{mbar}^{-1}\right)\end{array}$ & $\begin{array}{c}\text { Cleaning efficiency } \\
(\%)\end{array}$ \\
\hline 337 & physical & n.a. & n.a. & n.a. & n.a. & 0.154 & 0.234 & 30.3 \\
\hline 462 & physical & 0.932 & 0.514 & n.a & n.a. & 0.306 & 0.118 & 65.8 \\
\hline 552 & oxidant & 0.434 & 0.749 & 0.191 & n.a. & 0.312 & 0.115 & 77.4 \\
\hline 623 & acid & 0.156 & 0.290 & 0.345 & 0.054 & 0.508 & 0.071 & 59.4 \\
\hline 746 & acid & 0.490 & 0.039 & 0.202 & 0.083 & 0.420 & 0.086 & 45.8 \\
\hline 799 & acid & n.a. & n.a. & 0.162 & 0.107 & 0.241 & 0.150 & 57.1 \\
\hline 1044 & oxidant & 0.160 & 0.763 & 0.103 & n.a. & 0.151 & 0.239 & 88.5 \\
\hline 1163 & acid & 0.140 & 0.719 & 0.178 & 0.006 & 0.171 & 0.210 & 87.1 \\
\hline 1338 & oxidant & 0.243 & 0.097 & 0.653 & n.a. & 0.261 & 0.138 & 77.0 \\
\hline 1429 & oxidant & n.a. & n.a. & 0.373 & n.a. & 0.342 & 0.105 & 55.0 \\
\hline
\end{tabular}

n.a. - not analysed (1) Resistance due to the suspension $\left(R_{\text {bulk solution }}-R_{\text {before physical cleaning }}(2)\right.$ Resistance due to the dirt $\left(R_{\text {before physical cleaning }}-R_{\text {after physical cleaning }}\right)$ (3) Resistance due to the oxidant cleaning $\left(R_{\text {after physical cleaning }}-R_{\text {after oxidant cleaning }}\right)(4)$ Resistance due to the acid cleaning $\left(R_{\text {after oxidant cleaning }}-R_{\text {after acid cleaning }}\right)$ (5) Resistance after the last physical, oxidant or chemical cleaning.

$$
\text { New membrane resistance: } 0.038^{*} 10^{13} \mathrm{~m}^{-1} \quad \text { Permeability new membrane: } 0.958 \mathrm{~L} \mathrm{~m}^{-2} \mathrm{~h}^{-1} \mathrm{mbar}^{-1}
$$




\subsubsection{Physical and chemical cleaning in the AnSMBR}

\section{- Membrane 1}

During the entire period of operation of the AnSMBR pilot plant, the membrane was not physically or chemically cleaned. Following, are the results obtained in the different cleanings to each membranes. The values to the membrane resistance and permeability after each cleanin were showed.

Different cleaning processes mean that efficiency depends on the magnitude and type of fouling. The results shown below were affected by the different state of the membrane module. During the cleaning procedures, air recirculation with a superficial velocity of $60 \mathrm{~m} / \mathrm{h}$ to improve the cleanliness was used. The membrane resistance was determined from TMP monitoring versus the applied flux after taking out the membrane module.

Using the eq.3 from the section 7.4.4, the table 7.3 summarizes the cleaning efficiency for the membrane 1. After the physical cleaning an oxidant cleaning with $1000 \mathrm{ppm}$ of $\mathrm{NaClO}$ at $18^{\circ} \mathrm{C}$ was carried, without aire recirculation where was reached a cleaning efficiency of $76.9 \%$. Immediately, an oxidant cleaning with $1000 \mathrm{ppm}$ of $\mathrm{NaClO}$ at $18^{\circ} \mathrm{C}$, and aire recirculation with a superficial velocity of $60 \mathrm{~m} / \mathrm{h}$ reached a cleaning efficiency of $86.6 \%$. Subsequently other oxidant cleaning with 1000 ppm of $\mathrm{NaClO}$, aire recirculation with a superficial velocity of $60 \mathrm{~m} / \mathrm{h}$ and a temperature of $40^{\circ} \mathrm{C}$, allowed a cleaning efficiency of $95.2 \%$.

The results show that aire recirculation, and temperature, enhances the cleaning efficiency and the membrane resistance (decreasing the resistance involve an increase in the permeability).

After the oxidant cleaning, acid cleaning with acid citric $(1 \mathrm{~g} / \mathrm{L})$, at $40^{\circ} \mathrm{C}$ and aire recirculation with superficial velocity of $60 \mathrm{~m} / \mathrm{h}$ was done, and a cleaning efficiency of 98.5\% was observed. The use of other acids cleanings, such as $\mathrm{HCl}(1 \mathrm{~g} / \mathrm{L})$ and EDTA $(1 \% \mathrm{w})$, the membrane resistance was not recovered (Table 7.3$)$. 
Table 7.3. Effect of the cleaning procedures on membrane resistance, for the first membrane, after three years of operation.

\begin{tabular}{|c|c|c|c|}
\hline Type of cleaning & $\mathrm{R}_{\text {After }} * 10^{11}\left(\mathrm{~m}^{-1}\right)$ & Permeability $\left(\mathrm{L} \mathrm{m}^{-2} \mathrm{~h}^{-1} \mathrm{mbar}^{-1}\right)$ & Cleaning efficiency $(\%)$ \\
\hline Before physical cleaning & 144 & 0.025 & 0 \\
\hline After physical cleaning $\left(18^{\circ} \mathrm{C}\right)$ & 74.8 & 0.048 & 49.3 \\
\hline After oxidant cleaning $\left(18^{\circ} \mathrm{C}\right)$ & 36.0 & 0.100 & 76.9 \\
\hline After oxidant cleaning + agitation $\left(18^{\circ} \mathrm{C}\right)$ & 22.3 & 0.162 & 86.6 \\
\hline After oxidant cleaning + agitation $\left(40^{\circ} \mathrm{C}\right)$ & 10.2 & 0.355 & 95.2 \\
\hline After cleaning with citric acid $(1 \mathrm{~g} / \mathrm{L})+$ agitation $\left(40^{\circ} \mathrm{C}\right)$ & 5.8 & 0.622 & 98.4 \\
\hline After cleaning with citric acid $(2 \mathrm{~g} / \mathrm{L})+$ agitation $\left(40^{\circ} \mathrm{C}\right)$ & 5.6 & 0.643 & 98.5 \\
\hline After cleaning with $\mathrm{HCl}(1 \mathrm{~g} / \mathrm{L})+$ agitation $\left(40^{\circ} \mathrm{C}\right)$ & 5.6 & 0.640 & 98.5 \\
\hline After cleaning with EDTA $(1 \mathrm{w} \%)+$ agitation $\left(40^{\circ} \mathrm{C}\right)$ & 5.4 & 0.674 & 98.6 \\
\hline
\end{tabular}

Resistance of the first membrane: $3.518^{*} 10^{11} \mathrm{~m}^{-1}$ Permeability of the first membrane: $1.0234 \mathrm{~L} \mathrm{~m}^{-2} \mathrm{~h}^{-1} \mathrm{mbar}^{-1}$ 
In the figure 7.20 was represented the effect of physical, oxidant and acid cleanings in the TMP, and was observed that each improvement in the cleaning, allows achieve a higher fluxes.

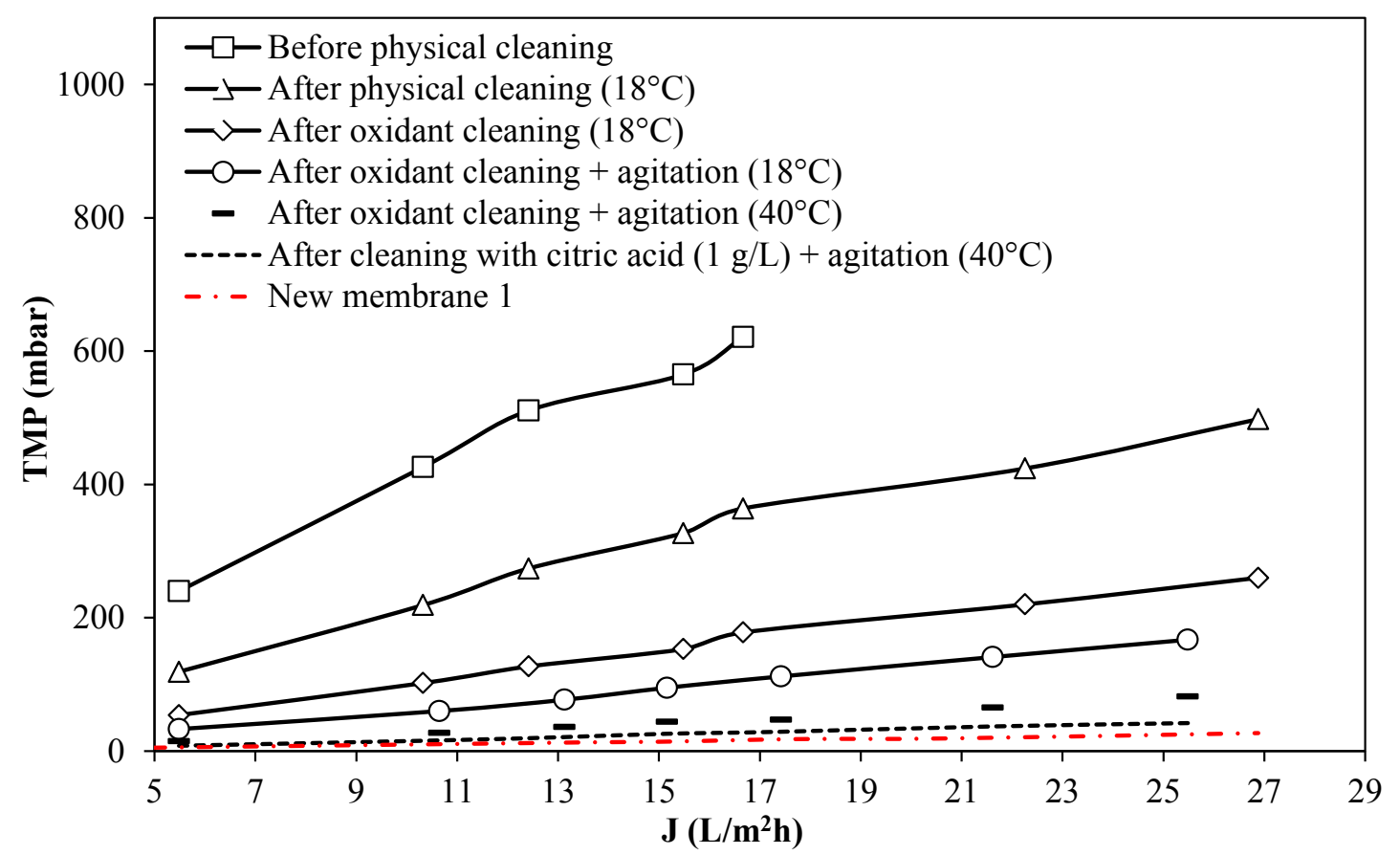

Figure 7.20. Evolution of the TMP after the cleaning procedures and three years of operation for the first membrane.

In figure 7.21 were shown the evolution of membrane with various cleaning procedures and conditions, and are observed three stages. In the first, after the physical cleaning, the fibers have a black color, because the organic matter was not removed (Fig. 7.21 (a)). The second stage were represented by an orange color, due to an oxidant cleaning with $1000 \mathrm{ppm}$ of $\mathrm{NaClO}$, with differents procedures and conditions, where the removal of organic matter takes place (Fig. 7.21 (b), (c), (d)). The third stage was characterized by the cleaning with citric acid with 1 and $2 \mathrm{~g} / \mathrm{L}$, the color changes from orange to white, due to the elimination of salts (Fig. 7.21 (e), (f)). With the addition of $\mathrm{HCl}$ and EDTA, the elimination of salts is null, because the membrane resistance and the cleaning efficiency remains constant (Fig. $7.21(\mathrm{~g}),(\mathrm{h})$ ). 

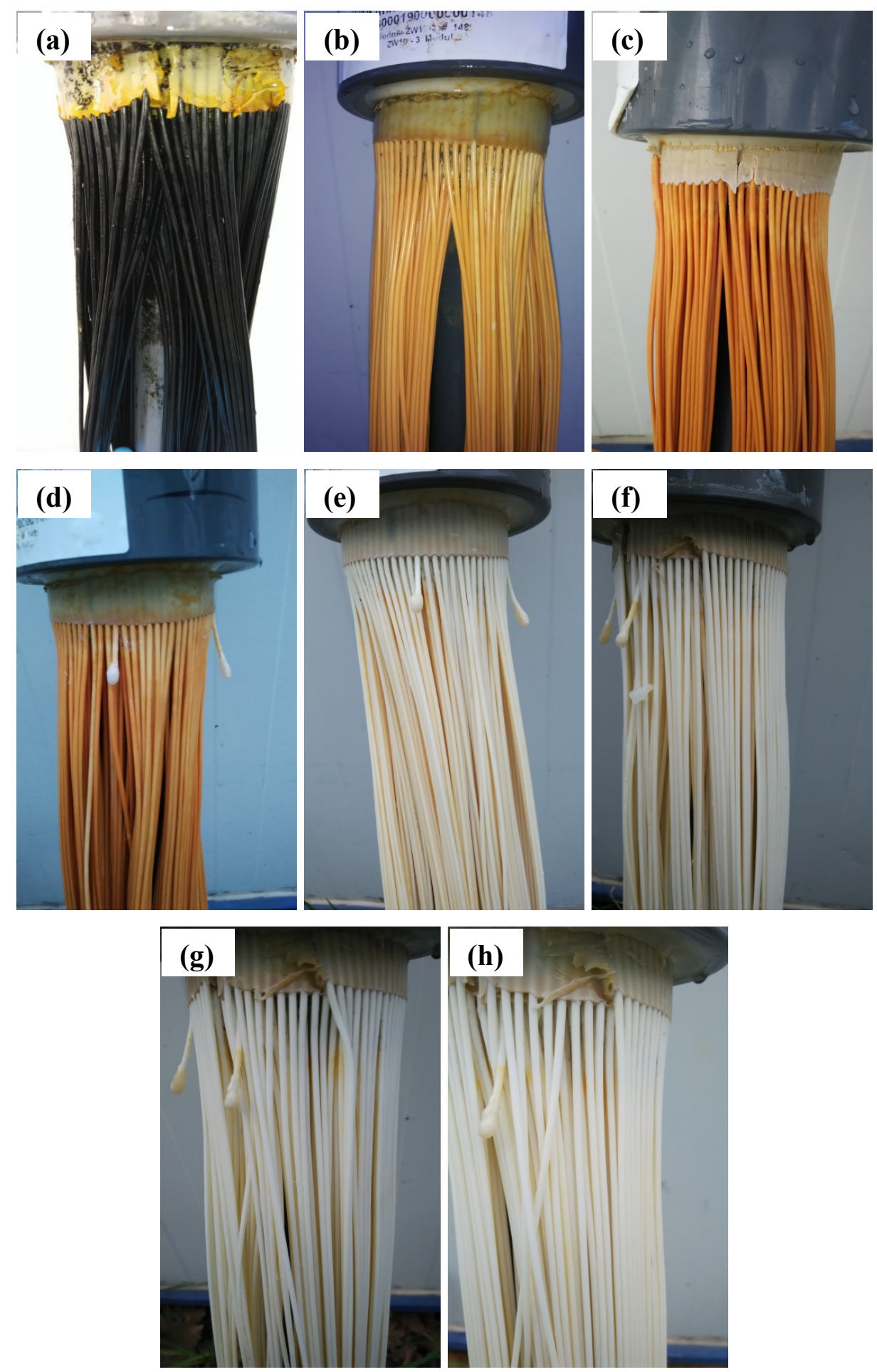

Figure 7.21. Evolution of physical appearance of the first membrane throughout the cleaning processes after three years of operation: (a) After physical cleaning $\left(18^{\circ} \mathrm{C}\right)$ (b) After oxidant cleaning $\left(18^{\circ} \mathrm{C}\right)$ (c) After oxidant cleaning + agitation $\left(18^{\circ} \mathrm{C}\right)(\mathbf{d})$ After oxidant cleaning + agitation $\left(40^{\circ} \mathrm{C}\right)($ e) After cleaning with citric acid $(1 \mathrm{~g} / \mathrm{L})+$ agitation $\left(40^{\circ} \mathrm{C}\right)(\mathbf{f})$ After cleaning with citric acid $(2 \mathrm{~g} / \mathrm{L})+$ agitation $\left(40^{\circ} \mathrm{C}\right)(\mathrm{g})$ After cleaning with $\mathrm{HCl}(1 \mathrm{~g} / \mathrm{L})+$ agitation $\left(40^{\circ} \mathrm{C}\right)$ (h) After cleaning with AEDT $(1 \mathrm{w} \%)+$ agitation $\left(40^{\circ} \mathrm{C}\right)$. 


\section{- Membrane 2}

Using the eq.3 from the section 7.4.4, the table 7.4 summarizes the cleaning efficiency for the membrane 2. After the physical cleaning an oxidant cleaning with $1000 \mathrm{ppm}$ of $\mathrm{NaClO}$ at $18^{\circ} \mathrm{C}$ was carried, without aire recirculation where was reached a cleaning efficiency of $74.9 \%$. Immediately, an oxidant cleaning with $1000 \mathrm{ppm}$ of $\mathrm{NaClO}$ at $18^{\circ} \mathrm{C}$, and aire recirculation with a superficial velocity of $60 \mathrm{~m} / \mathrm{h}$ was reached a cleaning efficiency of $91.9 \%$. This procedure compared with the membrane 1, was higher because, remained 13 days in water before performing this cleaning oxidant, allowing the dissolution of salts. With the acid cleaning with citric acid $(1 \mathrm{~g} / \mathrm{L})$, occurs the same behavior than in the membrane, reaching a cleaning efficiency of $97.3 \%$. The use of other acids cleanings, such as $\mathrm{HCl}(1 \mathrm{~g} / \mathrm{L})$ and EDTA $(1 \mathrm{w} \%)$, the membrane resistance was not recovered (Table 7.4). 
Table 7.4. Effect of the cleaning procedures on membrane resistance, for the second membrane, after three years of operation.

\begin{tabular}{|c|c|c|c|}
\hline Type of cleaning & $\mathbf{R}_{\text {After }}{ }^{*} 10^{11}\left(\mathrm{~m}^{-1}\right)$ & Permeability $\left(\mathrm{L} \mathrm{m}^{-2} \mathrm{~h}^{-1} \mathrm{mbar}^{-1}\right)$ & Cleaning efficiency $(\%)$ \\
\hline Before physical cleaning & 136 & 0.03 & 0 \\
\hline After physical cleaning $\left(18^{\circ} \mathrm{C}\right)$ & 76.5 & 0.05 & 44.6 \\
\hline After oxidant cleaning $\left(18^{\circ} \mathrm{C}\right)$ & 36.3 & 0.10 & 74.9 \\
\hline After oxidant cleaning + agitation $\left(18^{\circ} \mathrm{C}\right)$ & 13.7 & 0.26 & 91.9 \\
\hline After cleaning with citric acid $(1 \mathrm{~g} / \mathrm{L})+$ agitation $\left(18^{\circ} \mathrm{C}\right)$ & 6.5 & 0.55 & 97.3 \\
\hline After cleaning with citric acid $(2 \mathrm{~g} / \mathrm{L})+$ agitation $\left(18^{\circ} \mathrm{C}\right)$ & 6.2 & 0.59 & 97.5 \\
\hline After cleaning with $\mathrm{HCl}(1 \mathrm{~g} / \mathrm{L})+$ agitation $\left(18^{\circ} \mathrm{C}\right)$ & 5.9 & 0.61 & 97.7 \\
\hline After cleaning with EDTA $(1 \mathrm{w} \%)+$ agitation $\left(18^{\circ} \mathrm{C}\right)$ & 5.7 & 0.64 & 97.9 \\
\hline
\end{tabular}

Resistance of the second membrane: $2.861 * 10^{11} \mathrm{~m}^{-1}$ Permeability of the second membrane: $1.258 \mathrm{~L} \mathrm{~m}^{-2} \mathrm{~h}^{-1} \mathrm{mbar}^{-1}$ 
The effects of physical, chemical and acid cleanings in the TMP are represented in the Fig. 7.22 and the behavior was identical to the first membrane, which means that an improvement in the cleaning allows achieve a higher fluxes.

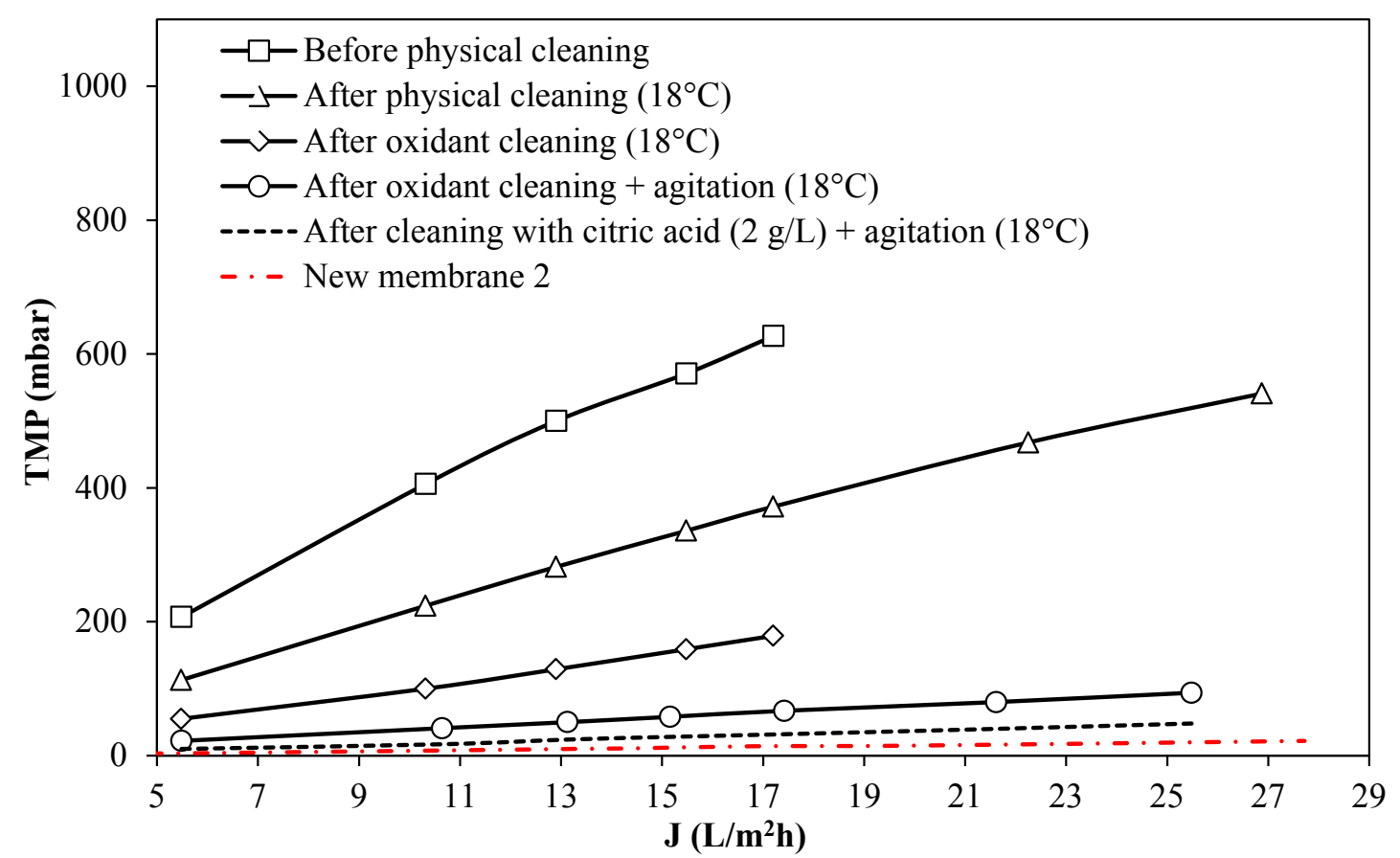

Figure 7.22. Evolution of the TMP after the cleaning procedures and three years of operation for the second membrane.

In figure 7.23 were shown the evolution of membrane cleaning with various procedures and conditions, having the same behavior as the membrane 1, with three stages. In the first, after the physical cleaning, the fibers have a black color, because the organic matter was not removed (Fig. 7.23 (a)). In the second stage was observed a orange color due to an oxidant cleaning with $1000 \mathrm{ppm}$ of $\mathrm{NaClO}$, with differents procedures and conditions, where the removal of organic matter takes place (Fig. 7.23 (b), (c)). In the third stage, the color changes from orange to white, due to the elimination of salts (Fig. 7.23 (d), (e)). With the addition of $\mathrm{HCl}$ and EDTA, the elimination of salts is null, because the membrane resistance and the cleaning efficiency remains constant (Fig. $7.23(\mathrm{f}),(\mathrm{g}))$. 


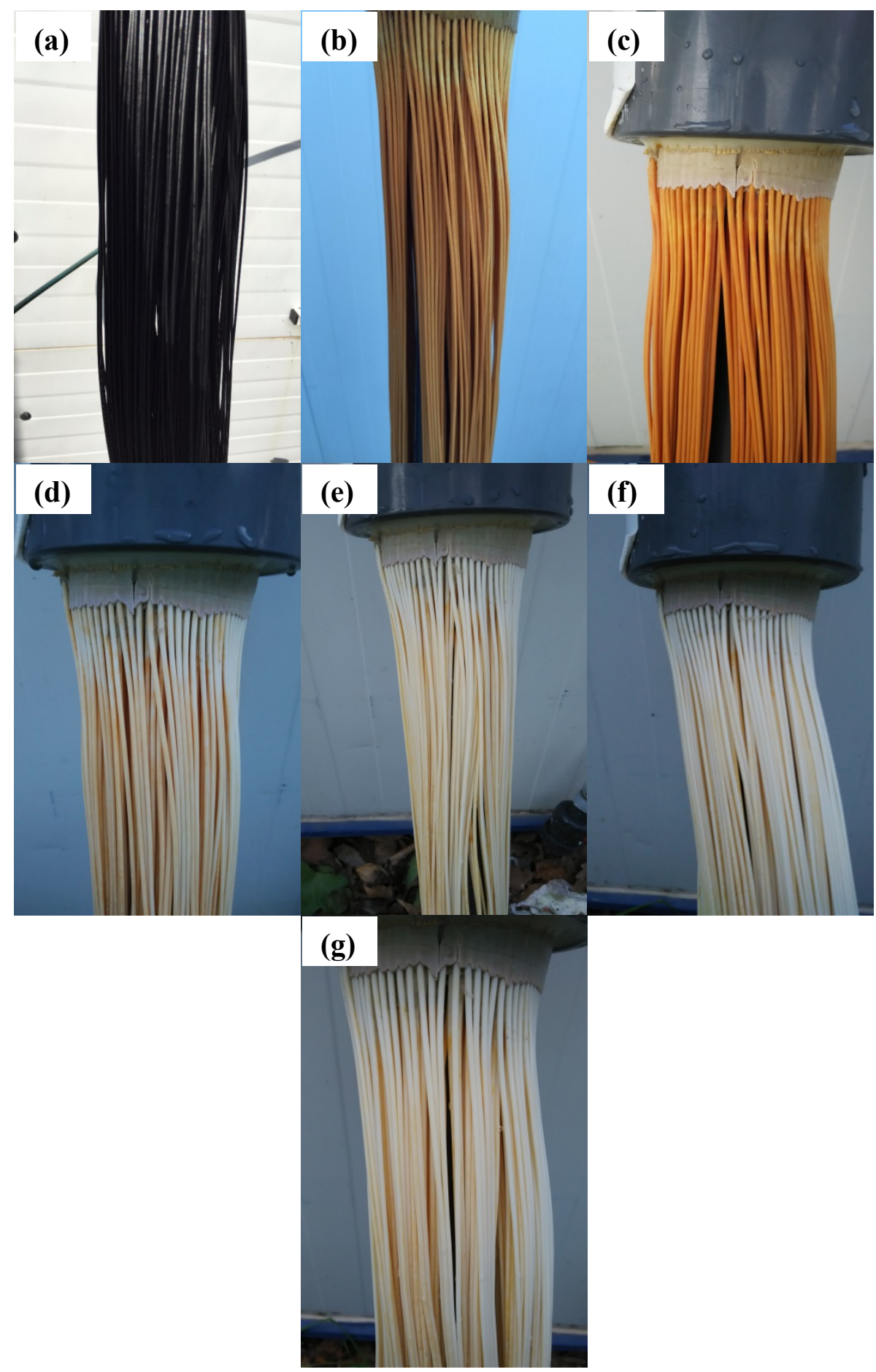

Figure 7.23. Evolution of physical appearance of the second membrane throughout the cleaning processes after three years of operation: (a) After physical cleaning $\left(18^{\circ} \mathrm{C}\right)$, (b) After oxidant cleaning $\left(18^{\circ} \mathrm{C}\right)$, (c) After oxidant cleaning + agitation $\left(18^{\circ} \mathrm{C}\right)$, (d) After cleaning with citric acid $(1 \mathrm{~g} / \mathrm{L})+$ agitation $\left(18^{\circ} \mathrm{C}\right)$, (e) After cleaning with citric acid $(2$ $\mathrm{g} / \mathrm{L})+$ agitation $\left(18^{\circ} \mathrm{C}\right)$, (f) After cleaning with $\mathrm{HCl}(1 \mathrm{~g} / \mathrm{L})+$ agitation $\left(18^{\circ} \mathrm{C}\right),(\mathrm{g})$ After cleaning with AEDT $(1 \mathrm{w} \%)+$ agitation $\left(18^{\circ} \mathrm{C}\right)$. 


\subsection{Conclusions}

The membrane resistance of the AnMBR $\left(0.0 .38^{*} 10^{13} \mathrm{~m}^{-1}\right)$, with the selected cleaning reagent once the membrane was fouled during the normal operation, was not recovered, reaching a cleaning efficiency between $65-88.5 \%$.

In the AnSMBR, after three years of operation, with the cleaning procedures used, the cleaning efficiency of the membrane 1 and 2 was $98.5 \pm 0.1 \%$ and $97.6 \pm 0.2 \%$, respectively.

Using different cleaning methods (physical, oxidant and acid) can be recovered almost all membrane resistance. Some factors affecting the cleaning efficiency, such as fouling of the fiber, air recirculation and temperature. The cake formation was identified as the reason for this increased resistance, as it was almost completely irreversible by physical cleaning. 


\subsection{References}

Ahmad, A.L., Che Lah, N.F., Ismail, S., Ooi, B.S., 2012. Membrane Antifouling Methods and Alternatives: Ultrasound Approach. Sep. Purif. Rev. 41, 318-346.

Albasi, C., Bessiere, Y., Desclaux, S., Remigy, J.C., 2002. Filtration of biological sludge by immersed hollow-fiber membranes: Influence of initial permeability choice of operating conditions. Desalination 146, 427-431.

An, D., Danhorn, T., Fuqua, C., Parsek, M.R., 2006. Quorum sensing and motility mediate interactions between Pseudomonas aeruginosa and Agrobacterium tumefaciens in biofilm cocultures. Proc. Natl. Acad. Sci. U. S. A. 103, 3828-3833.

Aslam, M., McCarty, P.L., Bae, J., Kim, J., 2014. The effect of fluidized media characteristics on membrane fouling and energy consumption in anaerobic fluidized membrane bioreactors. Sep. Purif. Technol. 132, 10-15.

Ayala, D.F., Ferre, V., Judd, S.J., 2011. Membrane life estimation in full-scale immersed membrane bioreactors. J. Memb. Sci. 378, 95-100.

Beier, S.P., Guerra, M., Garde, A., Jonsson, G., 2006. Dynamic microfiltration with a vibrating hollow fiber membrane module: Filtration of yeast suspensions. J. Memb. Sci. 281, 281-287.

Bhattacharjee, S., Kim, A.S., Elimelech, M., 1999. Concentration Polarization of Interacting Solute Particles in Cross-Flow Membrane Filtration. J. Colloid Interface Sci. 212, 81-99.

Bilad, M.R., Mezohegyi, G., Declerck, P., Vankelecom, I.F.J., 2012. Novel magnetically induced membrane vibration (MMV) for fouling control in membrane bioreactors. Water Res. 46, 63-72.

Braak, E., Alliet, M., Schetrite, S., Albasi, C., 2011. Aeration and hydrodynamics in submerged membrane bioreactors. J. Memb. Sci. 379, 1-18

Buzatu, P., Zsirai, T., Aerts, P., Judd, S.J., 2012. Permeability and clogging in an immersed hollow fibre membrane bioreactor. J. Memb. Sci. 421-422, 342-348. 
Castaing, J.B., Massé, A., Séchet, V., Sabiri, N., Pontié, M., Haure, J., Jaouen, P., 2011. Immersed hollow fi bres micro fi ltration ( $\mathrm{MF}$ ) for removing undesirable microalgae and protecting semi-closed aquaculture basins. Desalination 276, 386-396.

Chai, X., Kobayashi, T., Fujii, N., 1999. Ultrasound-associated cleaning of polymeric membranes for water treatment. Sep. Purif. Technol. 15, 139-146.

Charfi, A., Amar, N. Ben, 2012. Analysis of fouling mechanisms in anaerobic membrane bioreactors Total Suspended Solid concentration. Water Res. 46, 26372650 .

Chen, D., Columbia, M., 2011. Enzymatic control of alginate fouling of dead-end MF and UF ceramic membranes. J. Memb. Sci. 381, 118-125.

Chua, H.C., Arnot, T.C., Howell, J. a., 2002. Controlling fouling in membrane bioreactors operated with a variable throughput. Desalination 149, 225-229.

Davies, D.G., Parsek, M.R., Pearson, B.H., 1998. The Involvement of Cell-to-Cell Signals in the Development of a Bacterial Biofilm. Science. 280, 295-298.

Diez, V., Ramos, C., Cabezas, J.L., 2012. Treating wastewater with high oil and grease content using an Anaerobic Membrane Bioreactor (AnMBR). Filtration and cleaning assays. Water Sci. Technol. 65, 1847-1853.

El Rayess, Y., Albasi, C., Bacchin, P., Taillandier, P., Mietton-Peuchot, M., Devatine, A., 2012. Analysis of membrane fouling during cross-flow microfiltration of wine. Innov. Food Sci. Emerg. Technol. 16, 398-408.

Gabarrón, S., Gómez, M., Monclús, H., Rodríguez-Roda, I., Comas, J., 2013. Ragging phenomenon characterisation and impact in a full-scale MBR. Water Sci. Technol. $67,810-816$.

Giraldo, E., LeChevallier, M., 2007. Let them wear cake: a thin cake layer on the membranes can improve membrane bioreactor performance. Water Environ. Technol. 19, 46-51.

Giraldo, E., Systems, N., Water, L.A., 2006. Dynamic Mathematical Modeling of Membrane Fouling in. Am. Water, Innov. Environ. Steward. 4895-4913. 
Hong, S., Faibish, R., Elimelech, M., 1997. Kinetics of Permeate Flux Decline in Crossflow Membrane Filtration of Colloidal Suspensions. J. Colloid Interface Sci. $196,267-277$.

Huang, X. Wen, X.H., 2012. Principles and Applications of MBR for Water Treatment Science Press, Beijing, China.

Huang, X., Wei, C.H., Yu, K.C., 2008. Mechanism of membrane fouling control by suspended carriers in a submerged membrane bioreactor. J. Memb. Sci. 309, 7-16.

Hwang, K.J., Chan, C.S., Tung, K.L., 2009. Effect of backwash on the performance of submerged membrane filtration. J. Memb. Sci. 330, 349-356.

Jeison, D., van Lier, J.B., 2006. Cake layer formation in anaerobic submerged membrane bioreactors (AnSMBR) for wastewater treatment. J. Memb. Sci. 284, $227-236$.

Jeison, D., van Lier, J.B., 2007. Thermophilic treatment of acidified and partially acidified wastewater using an anaerobic submerged MBR: Factors affecting longterm operational flux. Water Res. 41, 3868-79.

Judd, S., 2011. The MBR Book: Principles and Applications of Membrane Bioreactors for Water and Wastewater Treatment, Second Edition.

Khalili-garakani, A., Mehrnia, M.R., Mostoufi, N., 2011. Analyze and control fouling in an airlift membrane bioreactor: CFD simulation and experimental studies. Process Biochem. 46, 1138-1145.

Kimura, K., Watanabe, Y., Ohkuma, N., 2000. Filtration resistance and efficient cleaning methods of the membrane with fixed nitrifiers. Water Res. 34, 28952904.

Kobayashi, T., Kobayashi, T., Hosaka, Y., Fujii, N., 2003. Ultrasound-enhanced membrane-cleaning processes applied water treatments: Influence of sonic frequency on filtration treatments. Ultrasonics 41, 185-190. 
Kola, A., Ye, Y., Le-clech, P., Chen, V., 2014. Transverse vibration as novel membrane fouling mitigation strategy in anaerobic membrane bioreactor applications. J. Memb. Sci. 455, 320-329.

Kraume, M., Wedi, D., Schaller, J., Iversen, V., Drews, A., 2009. Fouling in MBR : What use are lab investigations for full scale operation? Desalination 236, 94-103.

Le-Clech, P., Chen, V., Fane, T. a. G., 2006. Fouling in membrane bioreactors used in wastewater treatment. J. Memb. Sci. 284, 17-53.

Li, X., Li, J., Wang, J., Wang, H., He, B., Zhang, H., Guo, W., Hao, H., 2014. Experimental investigation of local $\mathrm{fl}$ ux distribution and fouling behavior in double-end and dead-end submerged hollow fi ber membrane modules. J. Memb. Sci. 453, 18-26.

Liao, B.-Q., Kraemer, J.T., Bagley, D.M., 2006. Anaerobic Membrane Bioreactors: Applications and Research Directions. Crit. Rev. Environ. Sci. Technol. 36, 489530.

Lim, A.L., Bai, R., 2003. Membrane fouling and cleaning in microfiltration of activated sludge wastewater. J. Memb. Sci. 216, 279-290.

Lin, H., Peng, W., Zhang, M., Chen, J., Hong, H., Zhang, Y., 2013. A review on anaerobic membrane bioreactors: Applications, membrane fouling and future perspectives. Desalination 314, 169-188

Liu, C., Caothien, S., Hayes, J., Caothuy, T., Otoyo, T., Ogawa, T., 2001. Membrane Chemical Cleaning : From Art to Science. Am. Water Work. Assoc. 25.

Low, S.C., Cheong, K.T., Lim, H.L., 2009. A vibration membrane bioreactor. Desalin. Water Treat. 5, 42-47.

Low, S.C., Juan, H.H., Siong, L.K., 2005. A combined VSEP and membrane bioreactor system. Desalination 183, 353-362.

Lowa, S.C., Hanb, H.J., Jinb, W.X., 2004. Characteristics of a vibration membrane in water recovery from fine carbon-loaded wastewater. Desalination 160, 83-90. 
Maartens, A., Swart, P., Jacobs, E.P., 1996. An enzymatic approach to the cleaning of ultrafiltration membranes fouled in abattoir effluent. J. Memb. Sci. 119, 9-16.

Martinez-Sosa, D., Helmreich, B., Netter, T., Paris, S., Bischof, F., Horn, H., 2011. Pilot-scale anaerobic submerged membrane bioreactor (AnSMBR) treating municipal wastewater: the fouling phenomenon and long-term operation. Water Sci. Technol. 64, 1804-11.

Meng, F., Chae, S.-R., Drews, A., Kraume, M., Shin, H.-S., Yang, F., 2009. Recent advances in membrane bioreactors (MBRs): membrane fouling and membrane material. Water Res. 43, 1489-1512.

Muñoz-Aguado, M.J., Wiley, D.E., Fane, A.G., 1996. Enzymatic and detergent cleaning of a polysulfone ultrafiltration membrane fouled with BSA and whey. J. Memb. Sci. 117, 175-187.

Ngo, H.H., Guo, W., Xing, W., 2008. Evaluation of a novel sponge-submerged membrane bioreactor (SSMBR) for sustainable water reclamation. Bioresour. Technol. 99, 2429-2435.

Porcelli, N., Judd, S., 2010. Chemical cleaning of potable water membranes: The cost benefit of optimisation. Water Res. 44, 1389-1398.

Porter, M.M.C., 1972. Concentration polarization with membrane ultrafiltration. Ind. Eng. Chem. Prod. Res. 11, 234.

Prip Beier, S., Jonsson, G., 2009. A vibrating membrane bioreactor (VMBR): Macromolecular transmission-influence of extracellular polymeric substances. Chem. Eng. Sci. 64, 1436-1444.

Qin, J.-J., Kekre, K.A., Oo, M.H., Tao, G., Lay, C.L., Lew, C.H., Cornelissen, E.R., Ruiken, C.J., 2010. Preliminary study of osmotic membrane bioreactor: effects of draw solution on water flux and air scouring on fouling. Water Sci. Technol. 62, $1353-1360$.

Raffin, M., Germain, E., Judd, S.J., 2012. Influence of backwashing, flux and temperature on microfiltration for wastewater reuse. Sep. Purif. Technol. 96, 147153. 
Ramos, C., Zecchino, F., Ezquerra, D., Diez, V., 2014. Chemical cleaning of membranes from an anaerobic membrane bioreactor treating food industry wastewater. J. Memb. Sci. 458, 179-188.

Ratkovich, N., Chan, C.C. V, Berube, P.R., Nopens, I., 2009. Experimental study and CFD modelling of a two-phase slug flow for an airlift tubular membrane. Chem. Eng. Sci. 64, 3576-3584.

Resosudarmo, A., Ye, Y., Le-Clech, P., Chen, V., 2013. Analysis of UF membrane fouling mechanisms caused by organic interactions in seawater. Water Res. 47, 911-921.

Rosenberger, S., Helmus, F.P., Krause, S., Bareth, A., Meyer-Blumenroth, U., 2011. Principles of an enhanced MBR-process with mechanical cleaning. Water Sci. Technol. 64, 1951-8.

Sarioglu, M., Insel, G., Orhon, D., 2012. Dynamic in-series resistance modeling and analysis of a submerged membrane bioreactor using a novel fi ltration mode. DES $285,285-294$.

Shrout, J.D., Nerenberg, R., 2012. Monitoring bacterial twitter: Does quorum sensing determine the behavior of water and wastewater treatment biofilms? Environ. Sci. Technol. 46, 1995-2005.

Stricot, M., Filali, A., Lesage, N., Spérandio, M., Cabassud, C., 2010. Side-stream membrane bioreactors: Influence of stress generated by hydrodynamics on floc structure, supernatant quality and fouling propensity. Water Res. 44, 2113-2124.

Sui, P., Wen, X., Huang, X., 2008. Feasibility of employing ultrasound for on-line membrane fouling control in an anaerobic membrane bioreactor. Desalination 219, 203-213.

Sun, Z.L., Chen, S.W., Wu, Z.C., 2003. Study on membrane performance in the operation of submerged membrane bioreactor (MBR), Environ. Eng. 21, 7-9.

Van den Brink, P., Vergeldt, F., Van As, H., Zwijnenburg, A., Temmink, H., van Loosdrecht, M.C.M., 2013. Potential of mechanical cleaning of membranes from a membrane bioreactor. J. Memb. Sci. 429, 259-267. 
Voet, D., Voet, J.G., Pratt, C.W., 1998. Fundamentals of Biochemistry. John Wiley \& Sons, Hoboken.

Wang, Q., Wang, Z., Wu, Z., Ma, J., Jiang, Z., 2012. Insights into membrane fouling of submerged membrane bioreactors by characterizing different fouling layers formed on membrane surfaces. Chem. Eng. J. 179, 169-177.

Wang, Y., Zhang, F., Chu, Y., Gao, B., Yue, Q., 2013. The dye or humic acid water treatment and membrane fouling by polyaluminum chloride composited with sodium alginate in coagulation-ultrafiltration process. Water Sci. Technol. 67, $2202-9$.

Wang, Z., Ma, J., Tang, C.Y., Kimura, K., Wang, Q., Han, X., 2014. Membrane cleaning in membrane bioreactors: A review. J. Memb. Sci. 468, 276-307.

Wang, Z., Wu, Z., 2009. A Review of Membrane Fouling in MBRs: Characteristics and Role of Sludge Cake Formed on Membrane Surfaces. Sep. Sci. Technol. 44, 35713596.

Wang, Z., Wu, Z., Tang, S., 2009. Extracellular polymeric substances (EPS) properties and their effects on membrane fouling in a submerged membrane bioreactor. Water Res. 43, 2504-2512.

Wang, Z., Wu, Z., Yin, X., Tian, L., 2008. Membrane fouling in a submerged membrane bioreactor (MBR) under sub-critical flux operation: Membrane foulant and gel layer characterization. J. Memb. Sci. 325, 238-244.

Wisniewski, C., Grasmick, A., 1998. Floc size distribution in a membrane bioreactor and consequences for membrane fouling. Colloids Surfaces A Physicochem. Eng. Asp. 138, 403-411.

Wu, J., Le-Clech, P., Stuetz, R.M., Fane, A.G., Chen, V., 2008. Effects of relaxation and backwashing conditions on fouling in membrane bioreactor. J. Memb. Sci. $324,26-32$.

Xia, L., Law, A.W.-K., Fane, A.G., 2013. Hydrodynamic effects of air sparging on hollow fiber membranes in a bubble column reactor. Water Res. 47, 3762-72. 
Xiong, Y., Liu, Y., 2010. Biological control of microbial attachment: A promising alternative for mitigating membrane biofouling. Appl. Microbiol. Biotechnol. 86, $825-837$.

Xu, H., Liu, Y., 2011. Control and cleaning of membrane biofouling by energy uncoupling and cellular communication. Environ. Sci. Technol. 45, 595-601.

Xu, M., Wen, X., Huang, X., Yu, Z., Zhu, M., 2013. Mechanisms of membrane fouling controlled by online ultrasound in an anaerobic membrane bioreactor for digestion of waste activated sludge. J. Memb. Sci. 445, 119-126.

Yang, Q., Chen, J., Zhang, F., 2006. Membrane fouling control in a submerged membrane bioreactor with porous, flexible suspended carriers. Desalination 189, $292-302$.

Yang, X., Wang, R, Fane, A.G., Tang, C.Y., Wenten, I.G., 2013. Membrane module design and dynamic shear-induced techniques to enhance liquid separation by hollow fiber modules: a review. Desalin. Water Treat. 51, 3604-3627.

Yeon, K.M., Lee, C.H., Kim, J., 2009. Magnetic enzyme carrier for effective biofouling control in the membrane bioreactor based on enzymatic quorum quenching. Environ. Sci. Technol. 43, 7403-7409.

Zhao, Y.J., Wu, K.F., Wang, Z.J., Zhao, L., Li, S.S., 2000. Fouling and cleaning of membrane - A literature review. J. Environ. Sci. English Ed.

Zhong, Z., Xing, W., Liu, X., Jin, W., Xu, N., 2007. Fouling and regeneration of ceramic membranes used in recovering titanium silicalite-1 catalysts. J. Memb. Sci. 301, 67-75.

Zsirai, T., Buzatu, P., Aerts, P., Judd, S., 2012. Efficacy of relaxation, backflushing, chemical cleaning and clogging removal for an immersed hollow fibre membrane bioreactor. Water Res. 46, 4499-4507.

D’Souza, N.M., Mawson, a J., 2005. Membrane cleaning in the dairy industry: a review. Crit. Rev. Food Sci. Nutr. 45, 125-134.

Shi, X., Tal, G., Hankins, N.P., Gitis, V., 2014. Fouling and cleaning of ultrafiltration membranes: A review. J. Water Process Eng. 1, 121-138. 

Chapter 8

\section{General conclusions}





\section{Anaerobic treatment}

$\checkmark$ The inoculation with non-acclimated sludge to psychrophilic conditions entails long startup periods. The sludge adaptation from mesophilic to psychrophilic conditions involves the loss of active biomass that, together with the low strength wastewater, is likely responsible of the slow start up.

$\checkmark$ The presence of the membrane might have facilitated the sludge granulation observed after eight months of re-inoculation. The membrane might contribute to sludge granulation, as it prevented the loss of inorganic material. The granules integrity remained during the rest of the operation of the reactor. Also in the AnSMBR pilot plant inoculated with granular sludge, the integrity of the granules remained during the whole operation.

$\checkmark$ The tCOD removal efficiency reached in both configurations, inoculated with different sludge, was around $87-89 \%$. However, the hidraulic residence time was higher in the AnSMBR than in the AnMBR. The AnMBR pilot plant reached tCOD removal efficiency of $87 \pm 1 \%$, operating with a volumetric loading rate between 2 and $2.5 \mathrm{~kg} \mathrm{tCOD} / \mathrm{m}^{3} \mathrm{~d}$, HRT of $7 \mathrm{~h}$, reaching effluent tCOD concentrations of $100-120 \mathrm{mg} / \mathrm{L}$ and $\mathrm{BOD}_{5}$ concentrations of $35-50 \mathrm{mg}$ $\mathrm{O}_{2} / \mathrm{L}$. Nevertheless, the AnSMBR also reached values of the tCOD in the effluent around $120 \mathrm{mg} \mathrm{tCOD} / \mathrm{L}$ but operating at HRT of 13-14 $\mathrm{h}$ and VLR between $1.5-2 \mathrm{~kg} \mathrm{tCOD} / \mathrm{m}^{3} \mathrm{~d}$.

$\checkmark$ The effluent from this treatment could be used for agriculture or irrigation purpose due to the complete mineralization of the organic nitrogen and the negligible low removal of phosphorus.

$\checkmark$ In the AnMBR the specific methane yield varied from 0.18 to $0.23 \mathrm{Nm}^{3} \mathrm{CH}_{4} / \mathrm{kg}$ $\mathrm{COD}_{\text {removed. }}$ depending on the recirculation between the membrane module and the UASB reactor. However, in the AnSMBR no significant differences were observed in the SMY when operating without or with recirculation. The respective values obtained were 0.226 and $0.216 \mathrm{Nm}^{3} \mathrm{CH}_{4} / \mathrm{g}$ tCOD $\mathrm{Cemoved}_{\text {. }}$ 
$\checkmark$ A disadvantage of the anaerobic treatment at psychrophilic temperature is the loss of dissolved methane in the effluent. The effluent from the AnSMBR was oversaturated. A mean value of dissolved methane of $19.1 \pm 0.9 \mathrm{mg} \mathrm{CH} / / \mathrm{L}$ was obtained, which implies around $15.3 \pm 5.3 \%$ of oversaturation.

$\checkmark$ The high turbulence in the membrane module contributes to the reduction of methane dissolved in the effluent of the AnMBR. Operating with recirculation, the biogas from the membrane module represented $26.4 \%$ of the total biogas production, however, this value decreasedas low as $13.7 \%$ of the total production without recirculation.

$\checkmark$ A fundamental effect of membrane is the accumulation of particulate COD slowly biodegradable at psychrophilic temperature or not biodegradable, inside the system, originating a great difference between the tCOD of the effluent and the soluble COD inside the membrane module. This accumulation increased with the increase of the VLR and depended on the content of particulate matter of the wastewater.

$\checkmark$ The specific methane yield obtained in both configurations, with respect to the theoretical value, indicates that around $60 \%$ of the tCOD is biologically removed and around $40 \%$ is accumulated in the system due to the ultrafiltration process. However, it is not biodegraded.

$\checkmark$ To facilitate membrane filtration and to reduce the fouling, periodical purges of the accumulated material from the membrane tank should be carried out.

$\checkmark$ Even with periodical purges the biosolid waste production was negligible. In the AnSMBR, the values were between $0.083 \mathrm{~g}$ VS/g tCODremoved, and $0.05 \mathrm{~g}$ $\mathrm{VS} / \mathrm{g}$ tCODremoved, with a wasting ratio between 1.1 and $0.3 \%$, respectively. 


\section{Membrane behavior}

$\checkmark$ To control the fouling of the membrane and to maintain the transmembrane pressure, continuous biogas sparging and permeate back-flush are needed.

$\checkmark$ The main parameters that affect membrane operation and membrane fouling are the solids concentration, the superficial velocity of the biogas and the filtration flux.

$\checkmark$ The filtration cycle used was 15 seconds back-flush, 5 seconds of relaxation time, 7.5 minutes filtration, and 5 seconds of relaxation time. Higher filtration time was not viable.

$\checkmark$ With the above filtration cycle, the AnMBR pilot plant has operated with a flux of between 10 and $12 \mathrm{~L} / \mathrm{m}^{2} \mathrm{~h}$ with a TMP between 400-550 mbar, during three years of stable operation, with a superficial biogas velocity between $40-60 \mathrm{~m} / \mathrm{h}$. The solid concentration in the membrane tank has been maintained around 2 and $6 \mathrm{~g} \mathrm{VS} / \mathrm{L}$.

$\checkmark$ In the AnMBR pilot plant, the membrane required chemical cleaning approximately every six months in order to maintain constant permeate flux during the filtration cycle.

$\checkmark$ The chemical cleaning with a solution of $\mathrm{NaClO}$ at $18-20^{\circ} \mathrm{C}$ at a concentration between 500-1000 ppm does not recovery the initial permeability of the membrane.

$\checkmark$ In the AnSMBR configuration, operating with the same filtration cycle than the AnMBR pilot plant, but with superficial biogas velocity between $9-16 \mathrm{~m} / \mathrm{h}$, the membrane operated with similar permeate flux around $12-14 \mathrm{~L} / \mathrm{m}^{2} \mathrm{~h}$ and similar TMP between 450-600 mbar. Nevertheless, during the three years of continuous operation, the membrane was not physically and chemically cleaned.

$\checkmark$ The different membranes behavior observed in both pilot plants could be due to the combination of three factors: the membrane configuration, the higher 
biosolids wasted in the AnSMBR, and the lower superficial velocity of the biogas sparging applied.

$\checkmark$ The use of various cleaning methods (physical, oxidant and acid), did not mean that the entire resistance was recovered.

$\checkmark$ The results obtained for the long-term operation of both pilot plants show the reliability and stability of the anaerobic membrane technology for the treatment of municipal wastewater at psychrophilic temperature. 


\section{List of Figures}



Figure 1.1. Metabolic pathway of anaerobic degradation.

Figure 1.2. Evolution of wastewater treatment. CW- constructed wetlands; RBC- rotating biological contactor; UASB- Up-flow Anaerobic Sludge Blanket; MBR- Membrane Bioreactor; SBR- Sequencing Batch Reactor; MBBR- Moving Bed Biofilm Reactor.

Figure 1.3. Schematic representation of UASB reactor and its configurations.

Figure 1.4. Different AnMBR system configurations: (a) internal submerged membrane; (b) external submerged membrane; (c) external cross-flow membrane.

Figure 1.5. Membrane separation processes.

Figure 1.6. Main factors affecting membrane fouling

Figure 1.7. MBR fouling mechanism map. The three stages of fouling.

Figure 3.1. Rotary sieve.

Figure 3.2. Schematic view and image of the primary settler used during the entire period of operation.

Figure 3.3. AnMBR pilot plant flow scheme (FI- Flow-rate Indicate; PTPressure Transmit; TT- Temperature Transmit; S.p.- sampling point).

Figure 3.4. AnMBR pilot plant: a) UASB reactor, b) external membrane tank.

Figure 3.5. Electric panels of the pilot plant: a) BS2100 regulator, b) timers 45 OMRON.

Figure 3.6. Data acquisicion card Picolog Technology Ltd.

Figure 3.7. AnSMBR pilot plant flow scheme (FI- Flow-rate Indicate; PT47 Pressure Transmit; TT- Temperature Transmit; S.p.- sampling point). 
Figure 3.8. AnSMBR pilot plant: UASB reactor with polymeric hollow fiber 48 membrane submerged internally on top.

Figure 3.9. Membrane module scheme Zenon ZW-10.

Figure 3.10. Characterization of the new membrane with tap water at $18 \pm 2^{\circ} \mathrm{C}$. (a) AnMBR, (b) AnSMBR.

Figure 3.11. Experimental set-up for MA and BMP tests.

Figure 4.1. AnMBR pilot plant flow scheme (FI- Flow-rate Indicate; PT66 Pressure Transmit; TT- Temperature Transmit; S.p.- Sampling point).

Figure 4.2. (a) Evolution of tCOD removal efficiency of the AnMBR, VLR and 71 HRT of UASB reactor. (b) Evolution of tCOD in the influent and effluent of AnMBR during the entire period of operation.

Figure 4.3. $\mathrm{N}-\mathrm{TKN}, \mathrm{N}-\mathrm{NH}_{4}{ }^{+}$concentration in the AnMBR (mean values) 79 during the entire period of operation.

Figure 4.4. Evolution of SCOD accumulation in the membrane module and

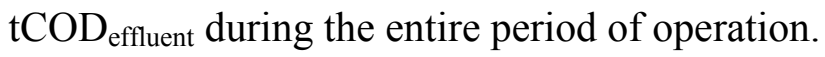

Figure 4.5. Evolution of TMP and permeate flux during the entire period of operation (arrows indicate the chemical cleaning).

Figure 5.1. Diagram of the slope to determine de specific cake resistance.

Figure 5.2. Diagram of the setup for measurement the specific cake resistance.

Figure 5.3. Critical flux measurement for the S.p.1: (a) stepwise flux increase and TMP response evolution, (b) TMP at end of each filtration and back flush period. Experimental conditions: biomass concentration, $13.81 \mathrm{~g}$ TS/L.

Figure 5.4. Critical flux measurement for the S.p.7: (a) stepwise flux increase and TMP response evolution, (b) TMP at end of each filtration and back flush period. Experimental conditions: biomass concentration, $10.03 \mathrm{~g} \mathrm{TS} / \mathrm{L}$. 
Figure 5.5. Critical flux measurement for the S.p.bell: (a) stepwise flux increase and TMP response evolution, (b) TMP at end of each filtration and back flush period. Experimental conditions: biomass concentration, $1.52 \mathrm{~g}$ TS/L.

Figure 5.6. Critical flux measurement for the S.p.6: (a) stepwise flux increase and TMP response evolution, (b) TMP at end of each filtration and back flush period. Experimental conditions: biomass concentration, $12.80 \mathrm{~g}$ TS/L.

Figure 5.7. Experimental data of the S.p.6 on day $404(\mathrm{TS}=13.67 \mathrm{~g} / \mathrm{L})$.

Figure 5.8. Experimental data of from S.p.6. a) without filtering $(\mathrm{TS}=5.79 \mathrm{~g} / \mathrm{L})$

b) filtered by $0.45 \mu \mathrm{m}(\mathrm{TS}=0.97 \mathrm{~g} / \mathrm{L})$.

Figure 5.9. Experimental data of the S.p. 6 on day $808(\mathrm{TS}=8.42 \mathrm{~g} / \mathrm{L})$.

Figure 5.10. Experimental data of the S.p.6 on day 1082 a) bulk solution (TS= $6.69 \mathrm{~g} / \mathrm{L})$ b) $3 \mathrm{~h}$ decanted $(\mathrm{TS}=4.65 \mathrm{~g} / \mathrm{L})$ c) $8 \mathrm{~h}$ decanted $(\mathrm{TS}=3.78 \mathrm{~g} / \mathrm{L})$.

Figure 5.11. Experimental data of the S.p.6 on day $1266(\mathrm{TS}=5.91 \mathrm{~g} / \mathrm{L})$.

Figure 5.12. Evolution of TMP with different dosages of polymer + tap water.

Figure 5.13. Turbidity of the supernatant of the bulk suspension from S.p.6 after 45 min of sedimentation with addition of MPE $50^{\mathrm{TM}}$.

Figure 5.14. Percentage removal of turbidity to different dosages of polymer 118 from the S.p.6.

Figure 5.15. Evolution of the TMP during the filtration cycle, in the minute 0 , 122 $16,32,48$ and 283, after adding the polymer MPE50 ${ }^{\mathrm{TM}}$.

Figure 5.16. Evolution of tCOD and sCOD on S.p.6 during the first assay, after adding the polymer MPE $50^{\mathrm{TM}}$.

Figure 5.17. Evolution of the TMP during the filtration cycle, in the minute 0 , $53,69,85,110$ and 410, after adding the polymer MPE50 ${ }^{\mathrm{TM}}$. 
Figure 5.18. Evolution of tCOD and sCOD on S.p.6 during the second assay, after adding the polymer MPE50 ${ }^{\mathrm{TM}}$.

Figure 6.1. AnSMBR pilot plant flow scheme (FI- Flow-rate Indicator; PTPressure Transmitter; TT- Temperature Transmitter; S.p.- Sampling points).

Figure 6.2. (a) Evolution of tCOD removal efficiency of the AnSMBR, VLR $_{\text {UASB }}$ and HRT $\mathrm{HASB}_{\text {. }}$ (b) Evolution of tCOD in the influent and effluent of AnSMBR during the period of operation.

Figure 6.3. Evolution of tCOD of the effluent (S.p.4), sCOD in the filtration section (S.p.3) during the entire period of operation (arrows indicate the purges of accumulated material; (a) - continuous purge).

Figure 6.4. Evolution of tCOD, sCOD in the UASB (S.p.2) and filtration section 153 (S.p.3) during the entire period of operation (arrows indicate the purges of accumulated material; (a) continuous purge).

Figure 6.5. Evolution of TMP and permeate flux during the entire period of 169 operation (arrows indicate the purges of accumulated material; (a) continuous purge).

Figure 7.1. In-situ and ex-situ cleaning of membranes. CEB: chemically enhanced backwash; CIP: cleaning-in-place; CIA: cleaning in air (in the drained membrane tank).

Figure 7.2. Mechanisms of chemical cleaning using acids, bases, oxidants and other chemicals. The binding sites shown are only for ilustration purposes. Symbols: 5 microbes (biomass); colloids; $\sim$ solutes. DTPA: ethylenetrinitrilopentaacetic acid; EDTA: ethylene diamine tetraacetic acid; SDS: sodium dodecyl sulfate; STP: sodium tripolyphosphate

Figure 7.3. Filtration resistance of the membrane in water at $18 \pm 2^{\circ} \mathrm{C}$, in bulk solution of S.p.6 and after the physical cleaning on day 337. 
Figure 7.4. Physical appearance of the membrane module throughout the cleaning processes on day 337: a) Bulk solution, $\mathrm{R}_{\mathrm{M}}=0.204^{*} 10^{13} \mathrm{~m}^{-1}$; b) After physical cleaning, $\mathrm{R}_{\mathrm{M}}=0.154 * 10^{13} \mathrm{~m}^{-1}$.

Figure 7.5. Filtration resistance of the membrane in water at $18 \pm 2^{\circ} \mathrm{C}$, in bulk 185 solution of S.p. 6 before and after the physical cleaning on day 462 .

Figure 7.6. Evolution of physical appearance of the membrane module throughout the cleaning processes on day 462 : a) Bulk solution, $\mathrm{R}_{\mathrm{M}}=1.752 * 10^{13}$ $\mathrm{m}^{-1}$; b) Before physical cleaning, $\mathrm{R}_{\mathrm{M}}=0.820 * 10^{13} \mathrm{~m}^{-1}$, c) After physical cleaning, $\mathrm{R}_{\mathrm{M}}=0.306^{*} 10^{13} \mathrm{~m}^{-1}$.

Figure 7.7. Filtration resistance of the membrane in water at $18 \pm 2^{\circ} \mathrm{C}$, in bulk 187 solution of S.p.6 before and after the physical cleaning, and after oxidant cleaning on day 552 .

Figure 7.8. Evolution of physical appearance of the membrane module 188 throughout the cleaning processes on day 552: a) Bulk solution, $\mathrm{R}_{\mathrm{M}}=1.686^{*} 10^{13}$ $\mathrm{m}^{-1}$; b) Before physical cleaning, $\mathrm{R}_{\mathrm{M}}=1.251 * 10^{13} \mathrm{~m}^{-1}$, c) After physical cleaning, $\mathrm{R}_{\mathrm{M}}=0.503 * 10^{13} \mathrm{~m}^{-1}$, d) After oxidant cleaning, $\mathrm{R}_{\mathrm{M}}=0.312 * 10^{13} \mathrm{~m}^{-1}$.

Figure 7.9. Filtration resistance of the membrane in water at $18 \pm 2^{\circ} \mathrm{C}$ in bulk 189 solution of S.p.6, before and after the physical cleaning, after oxidant and acid cleaning on day 623.

Figure 7.10. Physical appearance of the membrane module throughout the 190 cleaning processes on day 623: a) Bulk solution, $\mathrm{R}_{\mathrm{M}}=1.353^{*} 10^{13} \mathrm{~m}^{-1}$; b) Before physical cleaning, $\mathrm{R}_{\mathrm{M}}=1.197 * 10^{13} \mathrm{~m}^{-1}$, c) After physical cleaning, $\mathrm{R}_{\mathrm{M}}=$ $0.907 * 10^{13} \mathrm{~m}^{-1}$, d) After oxidant cleaning, $\mathrm{R}_{\mathrm{M}}=0.562 * 10^{13} \mathrm{~m}^{-1}$, e) After acid cleaning, $\mathrm{R}_{\mathrm{M}}=0.508 * 10^{13} \mathrm{~m}^{-1}$.

Figure 7.11. Resistance of the membrane in water at $18 \pm 2^{\circ} \mathrm{C}$, in bulk solution of S.p.6, before and after the physical cleaning, after oxidant and acid cleaning on day 746. 
Figure 7.12. Evolution of physical appearance of the membrane module throughout the cleaning processes on day 746 : a) Bulk solution, $\mathrm{R}_{\mathrm{M}}=1.234^{*} 10^{13}$ $\mathrm{m}^{-1}$ b) Before physical cleaning, $\mathrm{R}_{\mathrm{M}}=0.744 * 10^{13} \mathrm{~m}^{-1}$, c) After physical cleaning, $\mathrm{R}_{\mathrm{M}}=0.705 * 10^{13} \mathrm{~m}^{-1}$, d) After oxidant cleaning, $\mathrm{R}_{\mathrm{M}}=0.503 * 10^{13} \mathrm{~m}^{-1}$, e) After acid cleaning, $\mathrm{R}_{\mathrm{M}}=0.419 * 10^{13} \mathrm{~m}^{-1}$.

Figure 7.13. Resistance of the membrane in water at $18 \pm 2^{\circ} \mathrm{C}$, in bulk solution of S.p.6, before and after the physical cleaning, after oxidant and acid cleaning on day 799.

Figure 7.14. Resistance of the membrane in water at $18 \pm 2^{\circ} \mathrm{C}$, in bulk solution of 194 S.p.6, before and after the physical cleaning, and after oxidant cleaning on day 1044.

Figure 7.15. Resistance of the membrane in water at $18 \pm 2^{\circ} \mathrm{C}$, in bulk solution of 195 S.p.6, before and after the physical cleaning, after oxidant and acid cleaning on day 1163.

Figure 7.16. Resistance of the membrane in water at $18 \pm 2^{\circ} \mathrm{C}$, in bulk solution of 197 S.p.6, before and after the physical cleaning, and after oxidant cleaning on day 1338 .

Figure 7.17. Evolution of physical appearance of the membrane module throughout the cleaning processes on day 1338: a) Bulk solution, $R_{M}=$ $1.254 * 10^{13} \mathrm{~m}^{-1}$; b) Before physical cleaning, $\mathrm{R}_{\mathrm{M}}=1.011 * 10^{13} \mathrm{~m}^{-1}$, c) After physical cleaning, $R_{M}=0.913 * 10^{13} \mathrm{~m}^{-1}$, d) After oxidant cleaning, $R_{M}=$ $0.261 * 10^{13} \mathrm{~m}^{-1}$.

Figure 7.18. Resistance of the membrane in water at $18 \pm 2^{\circ} \mathrm{C}$, in bulk solution of S.p.6, after the physical cleaning, and after oxidant cleaning on day 1429.

Figure 7.19. Evolution of the TMP after each cleaning procedure.

Figure 7.20. Evolution of the TMP after the cleaning procedures and three years of operation for the first membrane. 
Figure 7.21. Evolution of physical appearance of the first membrane throughout the cleaning processes after three years of operation: (a) After physical cleaning $\left(18^{\circ} \mathrm{C}\right)$, (b) After oxidant cleaning $\left(18^{\circ} \mathrm{C}\right)$, (c) After oxidant cleaning + agitation $\left(18^{\circ} \mathrm{C}\right)$, (d) After oxidant cleaning + agitation $\left(40^{\circ} \mathrm{C}\right)$, (e) After cleaning with citric acid $(1 \mathrm{~g} / \mathrm{L})+\operatorname{agitation}\left(40^{\circ} \mathrm{C}\right)$, (f) After cleaning with citric acid $(2 \mathrm{~g} / \mathrm{L})+$ agitation $\left(40^{\circ} \mathrm{C}\right)$, (g) After cleaning with $\mathrm{HCl}(1 \mathrm{~g} / \mathrm{L})+$ agitation $\left(40^{\circ} \mathrm{C}\right)$, (h) After cleaning with AEDT $(1 \mathrm{w} \%)+$ agitation $\left(40^{\circ} \mathrm{C}\right)$.

Figure 7.22. Evolution of the TMP after the cleaning procedures and three years of operation for the second membrane.

Figure 7.23. Evolution of physical appearance of the second membrane throughout the cleaning processes after three years of operation: (a) After physical cleaning $\left(18^{\circ} \mathrm{C}\right)$, (b) After oxidant cleaning $\left(18^{\circ} \mathrm{C}\right)$, (c) After oxidant cleaning + agitation $\left(18^{\circ} \mathrm{C}\right)$, (d) After cleaning with citric acid $(1 \mathrm{~g} / \mathrm{L})+$ agitation $\left(18^{\circ} \mathrm{C}\right)$, (e) After cleaning with citric acid $(2 \mathrm{~g} / \mathrm{L})+$ agitation $\left(18^{\circ} \mathrm{C}\right)$, (f) After cleaning with $\mathrm{HCl}(1 \mathrm{~g} / \mathrm{L})+$ agitation $\left(18^{\circ} \mathrm{C}\right)$, (g) After cleaning with AEDT (1 $\mathrm{w} \%)+$ agitation $\left(18^{\circ} \mathrm{C}\right)$. 



\section{List of Tables}



Table 1.1. Advantages and disadvantages of anaerobic wastewater treatment.

Table 1.2. Comparison of conventional aerobic treatment, anaerobic treatment, aerobic MBR and AnMBR.

Table 3.1. Characteristics of the membrane module Zenon ZW-10 used in both pilot plants.

Table 3.2. Membrane resistance and permeability of the new membrane for both pilot plants.

Table 4.1. Presettled wastewater characteristics fed to the UASB reactor (average values).

Table 4.2. Principal parameters of operation of AnMBR, (average values).

Table 5.1. Critical flux of the AnMBR pilot plant on day 450 .

Table 5.2. Specific cake resistance of the bulk solution from the different S.p. of the AnMBR on day 404, without gas recirculation.

Table 5.3. Particle size distribution from the different S.p. of the AnMBR on day 404.

Table 5.4. Specific cake resistance of the bulk solution from diferents sampling points on day 443, without gas recirculation.

Table 5.5. Particle size distribution from the different S.p. of the AnMBR on day 109 443.

Table 5.6. Specific cake resistance of the bulk solution from the different S.p. of the AnMBR on day 808, without gas recirculation.

Table 5.7. Specific cake resistance of the bulk solution from S.p.6 of the AnMBR on day 1082, without gas recirculation. 
Table 5.8. Particle size distribution from the S.p.6 of the AnMBR on day 1082 .

Table 5.9. Specific cake resistance of the bulk solution from the different S.p. of the AnMBR on day 1266, without gas recirculation.

Table 5.10. Specific cake resistance of the sludge from different sampling points with a flux between $10-12 \mathrm{~L} / \mathrm{m}^{2} \mathrm{~h}$.

Table 5.11. Turbidity measurements (mean values) with different concentrations of MPE $50^{\mathrm{TM}}$ with tap water.

Table 5.12. Evolution of tCOD removal efficiency with different dosages of MPE50 ${ }^{\mathrm{TM}}$ with the supernatant.

Table 5.13. Evolution of tCOD with different dosages of MPE $50^{\mathrm{TM}}$ with the supernatant filtered with the fiber.

Table 5.14. Specific cake resistance of the bulk suspension with different dosages of polymer on day 525 .

Table 5.15. Specific cake resistance of the bulk solution with different dosages of polymer on day 544 .

Table 5.16. Specific cake resistance from S.p.6, after adding the polymer, with a 123 flux of $11.3 \mathrm{~L} / \mathrm{m}^{2} \mathrm{~h}$ and $\mathrm{u}_{\mathrm{g}}=60 \mathrm{~m} / \mathrm{h}$.

Table 5.17. Specific cake resistance from S.p.6, after adding the polymer with a 126 flux of $11.3 \mathrm{~L} / \mathrm{m}^{2} \mathrm{~h}$ and differents superficial velocities.

Table 6.1. Presettled wastewater characteristics fed to the UASB (average 141 values).

Table 6.2. Principal parameters of operation of AnSMBR (average values).

Table 6.3. Biogas composition during Period II.1 and Period II.2. 
Table 6.4. Desorbed methane to the gas phase and methane dissolved in the liquid phase after desorption, in samples from the UASB reactor (S.p.2) and from the effluent (S.p.4).

Table 6.5. Purges carried out from the filtration section (S.p.3) of the AnSMBR.

Table 7.1 VS concentration (mean values) in the bulk solution from S.p.6 200 between each period.

Table 7.2. Effect of the cleaning procedures on membrane resistance, during the entire period of operation.

Table 7.3. Effect of the cleaning procedures on membrane resistance, for the first membrane, after three years of operation.

Table 7.4. Effect of the cleaning procedures on membrane resistance, for the second membrane, after three years of operation. 

Nomenclature 



\begin{tabular}{|c|c|}
\hline$A C$ & Activated Carbon \\
\hline$A D$ & Anaerobic Digestion \\
\hline AeMBR & Aerobic Membrane Bioreactor \\
\hline$A F$ & Anaerobic Filter \\
\hline$A F B$ & Anaerobic Fluidized Bed \\
\hline $\boldsymbol{A H}$ & Anaerobic Hybrid \\
\hline$A n M B R$ & Anaerobic Membrane Bioreactor \\
\hline $\operatorname{AnSMBR}$ & Anaerobic Submerged Membrane Bioreactor \\
\hline $\boldsymbol{A T P}$ & Adenosine Triphosphate \\
\hline $\boldsymbol{B M P}$ & Biochemical Methane Potential \\
\hline$B O D$ & Biochemical Oxygen Demand \\
\hline$C D M$ & Clean Development Mechanism \\
\hline$C E B$ & Chemically Enhanced Backflush \\
\hline $\boldsymbol{C F V}$ & Cross Flow Velocity \\
\hline $\boldsymbol{C I} \boldsymbol{A}$ & Cleaning in Air \\
\hline CIP & Cleaning in Place \\
\hline$C O D$ & Chemical Oxygen Demand \\
\hline COP & Cleaning Out of Place \\
\hline $\boldsymbol{C P}$ & Concentration Polarization \\
\hline $\mathrm{DCH}_{4}$ & Dissolved Methane \\
\hline$D T P A$ & Diethylenetrinitrilopenta Acetic Acid \\
\hline$D W W$ & Domestic Wastewater \\
\hline$E D T A$ & Ethylene diamine tetra acetic acid \\
\hline$E G S B$ & Expanded Granular Sludge Blanket \\
\hline EPS & Extracellular Polymeric Substances \\
\hline$F / M$ & Food to Microorganisms ratio \\
\hline$F B$ & Fluidized Bed \\
\hline $\boldsymbol{G} A \boldsymbol{C}$ & Granular Activated Carbon \\
\hline$G C-F I D$ & Gas Chromatography - Flame Ionization Detector \\
\hline$G L S$ & Gas-Liquid-Solid \\
\hline $\boldsymbol{H F}$ & Hollow Fiber \\
\hline$H P L C-I C$ & High Performance Liquid Chromatography-Ion Chromatography \\
\hline$H R T$ & Hydraulic Retention Time \\
\hline
\end{tabular}




\begin{tabular}{|c|c|}
\hline $\boldsymbol{J}$ & Permeate Flux \\
\hline $\boldsymbol{K}$ & Membrane Permeability \\
\hline$M B R$ & Membrane Bioreactor \\
\hline MF & Microfiltration \\
\hline MLSS & Mixed Liquor Suspended Solid \\
\hline MPE & Membrane Performance Enhancer \\
\hline$M W$ & Molecular Weight \\
\hline$O L R$ & Organic Loading Rate \\
\hline$P A C$ & Powdered Activated Carbon \\
\hline$P E$ & Polyethylene \\
\hline PES & Polyethersulfone \\
\hline $\boldsymbol{P P}$ & Polypropylene \\
\hline$P P H$ & Polypropylene Homo-Polymer's \\
\hline PSD & Particle Size Distribution \\
\hline$P S F$ & Polysulfone \\
\hline$P V C$ & Poly(vinyl chloride) \\
\hline$P V D F$ & Polyvinylidene Difluoride \\
\hline$P V P$ & Polyvinyl Pyrrolidone \\
\hline $\boldsymbol{R}_{C}$ & Resistance Cake \\
\hline $\boldsymbol{R}_{M}$ & Membrane Resistance \\
\hline S.p. & Sampling points \\
\hline$S A D m$ & Specific Aeration Demand \\
\hline$S D S$ & Sodium Dodecyl Sulfate \\
\hline$S M A$ & Specific Methanogenic Activity \\
\hline$S M P$ & Soluble Microbial Products \\
\hline$S M Y$ & Specific Methane Yeld \\
\hline$S R T$ & Solid Retention Time \\
\hline$S S$ & Suspended Solids \\
\hline$S T P$ & Sodium Tripolyphosphate \\
\hline$T M P$ & Transmembrane Pressure \\
\hline $\operatorname{TrCOs}$ & Trace Organic Chemicals \\
\hline$T S$ & Total Solids \\
\hline$T S S$ & Total Suspended Solids \\
\hline
\end{tabular}




$\begin{array}{ll}\boldsymbol{U A S B} & \text { Upflow Anaerobic Sludge Blanket } \\ \boldsymbol{U F} & \text { Ultrafiltration } \\ \boldsymbol{u}_{\boldsymbol{g}} & \text { Superficial Velocity } \\ \boldsymbol{V F A} & \text { Volatile Fatty Acid } \\ \boldsymbol{V H F M} & \text { Vibrating Hollow Fiber Modules } \\ \boldsymbol{V L R} & \text { Volumetric Loading Rate } \\ \boldsymbol{V S} & \text { Volatile Solids } \\ \boldsymbol{V S E P} & \text { Vibratory Shear Enhanced Process } \\ \boldsymbol{V S S} & \text { Volatile Suspended Solids } \\ \boldsymbol{W W T P} & \text { WasteWater Treatment Plant } \\ \boldsymbol{\alpha} & \text { Specific Cake Resistance } \\ \boldsymbol{\mu} & \text { Permeate viscosity }\end{array}$


